\title{
Review of the Invasive Asian Clam Corbicula spp. (Bivalvia: Cyrenidae) Distribution in North America, 1924-2019
}
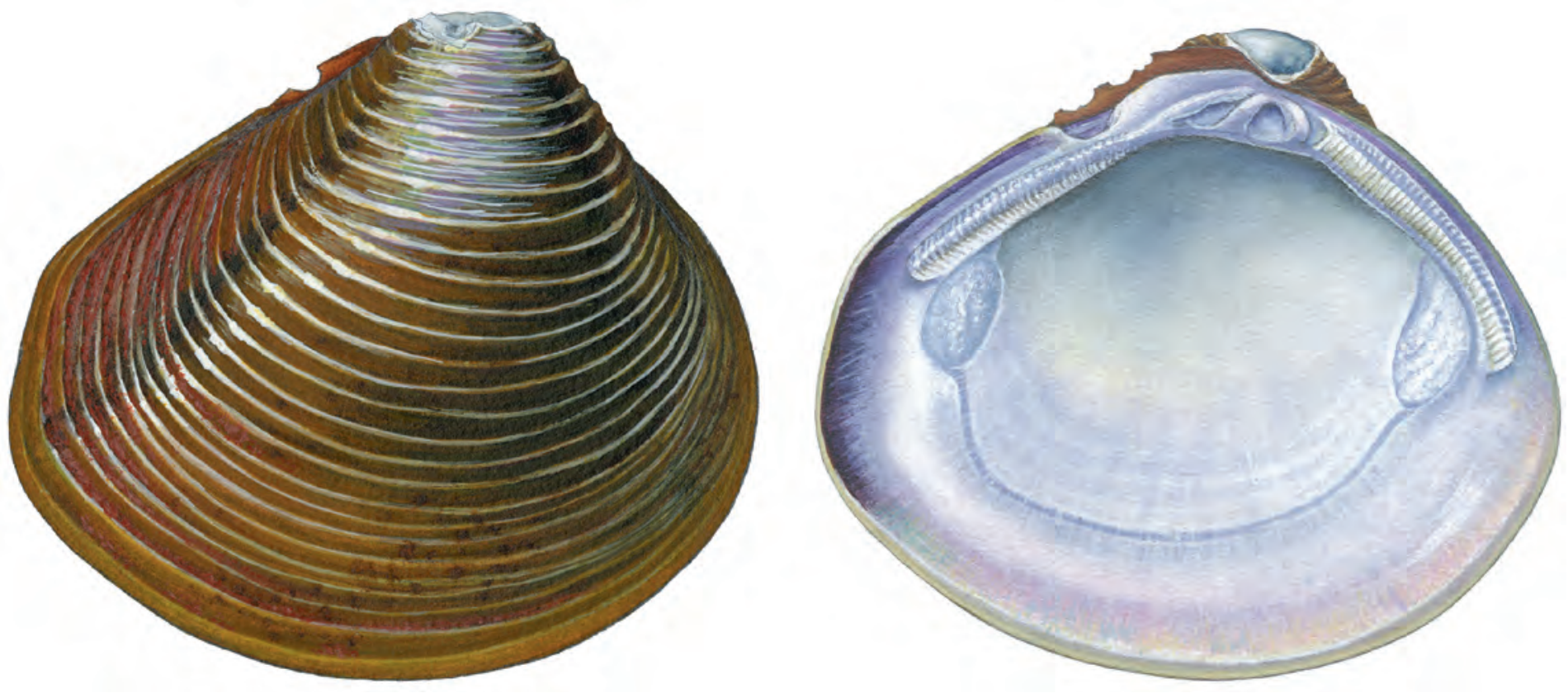

Scientific Investigations Report 2021-5001 
Cover, Artistic rendering of a Corbicula fluminea specimen (length 30 millimeters) collected from the Choctawhatchee River in northwestern Florida on June 3, 1998. Illustration by S. Trammell; used with permission. 


\section{Review of the Invasive Asian Clam Corbicula spp. (Bivalvia: Cyrenidae) Distribution in North America, 1924-2019}

By Amy J. Benson and James D. Williams

Scientific Investigations Report 2021-5001 


\section{U.S. Geological Survey, Reston, Virginia: 2021}

For more information on the USGS - the Federal source for science about the Earth, its natural and living resources, natural hazards, and the environment—visit https://www.usgs.gov or call 1-888-ASK-USGS.

For an overview of USGS information products, including maps, imagery, and publications, visit https://store.usgs.gov/.

Any use of trade, firm, or product names is for descriptive purposes only and does not imply endorsement by the U.S. Government.

Although this information product, for the most part, is in the public domain, it also may contain copyrighted materials as noted in the text. Permission to reproduce copyrighted items must be secured from the copyright owner.

Suggested citation:

Benson, A.J., and Williams, J.D., 2021, Review of the invasive Asian clam Corbicula spp. (Bivalvia: Cyrenidae) distribution in North America, 1924-2019: U.S. Geological Survey Scientific Investigations Report 2021-5001, 66 p., https://doi.org/10.3133/sir20215001.

Associated data for this publication:

Benson, A.J., and Williams, J.D., 2021, Corbicula spp. locations in the United States from 1964 to 2019: U.S.

Geological Survey data release, https://doi.org/10.5066/P9JKHE3F.

ISSN 2328-0328 (online) 


\section{Acknowledgments}

A project of this scope would not have been possible without the assistance of curators and collection managers at numerous natural history museums and universities. We wish to acknowledge the support of the following individuals for their responses to our data requests and for the expeditious cataloging of select museum voucher specimens for inclusion in this review: Art Bogan and Jamie Smith, North Carolina Museum of Natural Sciences; Lisa Boucher, University of Texas at Austin; Paul Callomon, Academy of Natural Sciences of Drexel University; Kevin Cummings and Rachel Vinsel, Illinois Natural History Survey; Clare Cunningham, Baylor University Mayborn Museum; Paula Cushing and Phyllis Sharp, Denver Museum of Nature and Science; Gerald Dinkins, University of Tennessee McClung Museum; Leanne Elder, University of Colorado Boulder Museum of Natural History; Melissa Frey, University of Washington Burke Museum of Natural History and Culture; Heidi Gartner, Royal British Columbia Museum; Lindsey Groves, Natural History Museum of Los Angeles County; Robert Jones (retired), Mississippi Museum of Natural Science; Sean Keogh, University of Minnesota Bell Museum; Eric LazoWasem, Yale Peabody Museum of Natural History; Taehwan Lee, University of Michigan Museum of Zoology; Charles Mather, University of Science and Arts of Oklahoma; Timothy Pearce, Carnegie Museum of Natural History; Tina Petway, Houston Museum of Natural Science; Steven Platania and Alexandra Snyder, University of New Mexico Museum of Southwestern Biology; Elizabeth Shea, Delaware Museum of Natural History; Mark Siddall and Lily Berniker, American Museum of Natural History; John Slapcinsky, Florida Museum of Natural History, University of Florida; Ellen Strong, National Museum of Natural History, Smithsonian Institution; Tom Watters and Caitlin Byrne, The Ohio State University Museum of Biological Diversity; and Norine Yeung, Bishop Museum.

We are grateful for the generous assistance of Federal and State agency biologists and independent aquatic ecologists during the process of compiling collection records. We acknowledge the support of the following individuals: John Alderman, Alderman Environmental Services; Mark Anderson, National Park Service; Matthew Ashton and Martin Hurd, Maryland Department of Natural Resources; James Barnett, Arkansas Game and Fish Commission; Beth Bear, Wyoming Game and Fish Department; Matthew Berg, Endangered Resource Services, LLC; Kevin Cummings and Jeremy Tiemann, Illinois Natural History Survey; Gary Czypinski, U.S. Fish and Wildlife Service; Larry Dalton (retired), Utah Division of Wildlife Resources; Amy Ferriter, Idaho Fish and Game; Maureen Ferry, Wisconsin Department of Natural Resources; Danika Frisbie, Vermont Agency of Natural Resources; Felix Grana, Puerto Rico Department of Natural and Environmental Resources; Scott Gritters, lowa Department of Natural Resources; Elizabeth Herron, University of Rhode Island; Jennifer Hoffman, Susquehanna River Basin Commission; Robert Howells (retired), Texas Parks and Wildlife Department; Michael Insko, U.S. Army Corps of Engineers; Byron Karns, National Park Service; Eugene Keferl (retired), College of Coastal Georgia; Kevin Kelly, Pennsylvania Department of Environmental Protection; Rob Kibler, U.S. Fish and Wildlife Service; Gerald Mackie (retired), University of Guelph; William McDowell, Merrimack College; Stephen McMurray, Missouri Department of Conservation; Anjie Montalvo, California Department of Fish and Wildlife; Tom Mosher (retired), Kansas Department of Wildlife, Parks, and Tourism; North Carolina Wildlife Resources Commission; Suzanne O'Connell, Wesleyan University; Victor Poretti, New Jersey Department of Environmental Protection; Charles Randklev, Texas A\&M University; Terry Richardson, University of North Alabama; Matt Rowe, Georgia Department of Natural Resources; Barbara Sargent, West Virginia Division of Natural Resources; Steve Schainost (retired), Nebraska Game and Parks Commission; Don Schall, ENSR International Corporation; Stacy Schmidt, Montana Fish, Wildlife and Parks; 
Jesse Schultz, Washington Department of Fish and Wildlife; Amy Smagula, New Hampshire Department of Environmental Services; Michael Smith, South Dakota Game, Fish, and Parks; Jeff Thomas and John Spaeth, Ohio River Valley Water Sanitation Commission; Lusha Tronstad, University of Wyoming; Kim Uyehara, U.S. Fish and Wildlife Service; Eric Wagner, Utah Division of Wildlife Resources; Mary Walsh, Western Pennsylvania Conservancy and Pennsylvania Natural Heritage Program; Brian Watson and Jay Kapalczynski, Virginia Department of Wildlife Resources; and Jason Wisniewski, Tennessee Wildlife Resources Agency. We thank S. Bostick for reviews of this manuscript and extend a special thank you to J. Tiemann and S. McMurray for their thoughtful reviews of the final manuscript.

We also thank P. Fuller, M. Cannister, W. Daniel, L. Evrard, D. Gregoire-Lucente, M. Layhee, and M. Vinson of the U.S. Geological Survey for their technical support and assistance, as well as L. Nico of the U.S. Geological Survey for information on live food markets. 


\section{Contents}

Acknowledgments ...................................................................................................................ii

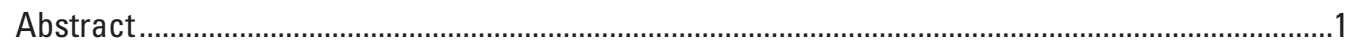

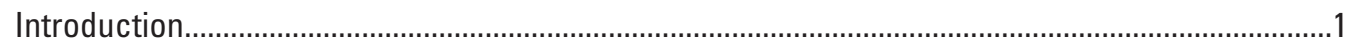

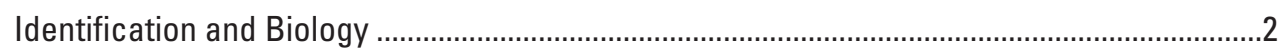

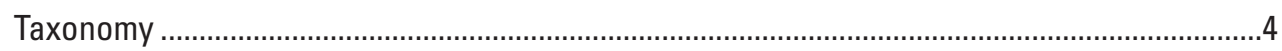

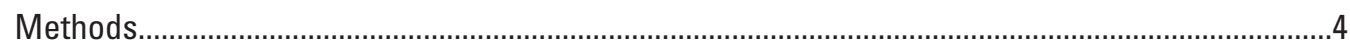

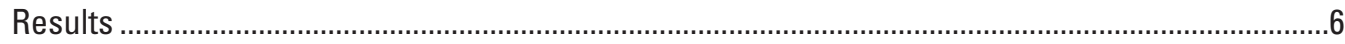

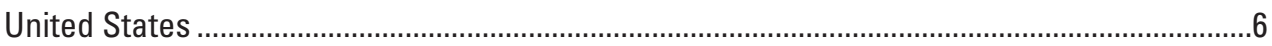

States and Territories With First Occurrence of Corbicula Post-1984............................11

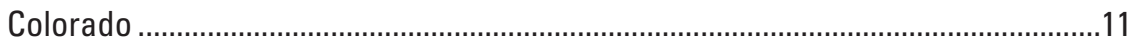

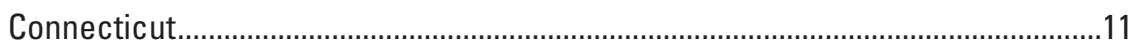

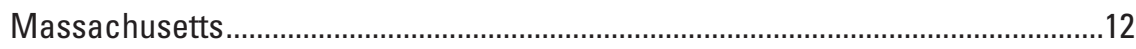

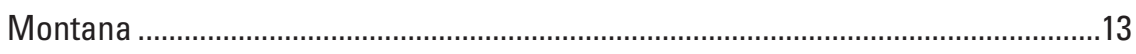

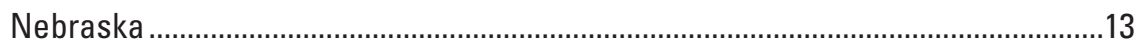

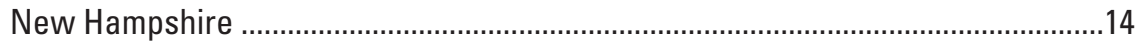

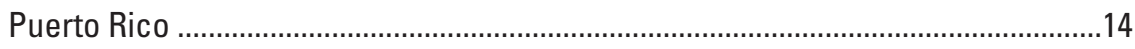

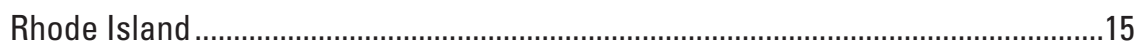

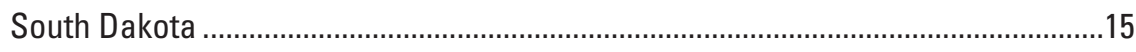

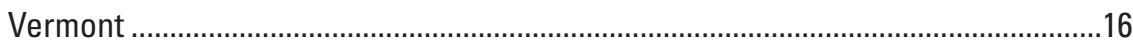

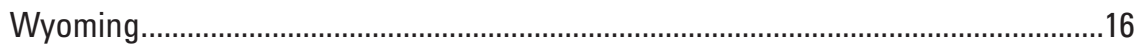

Corbicula Occurrences in Additional Waterbodies of States and Districts Where It Was Present Prior to 1985 .............................................................

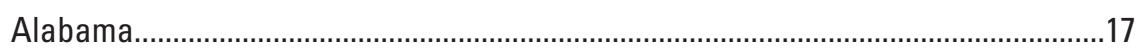

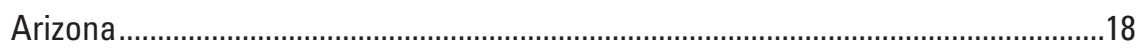

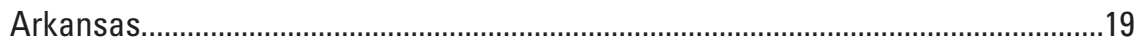

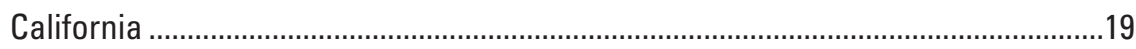

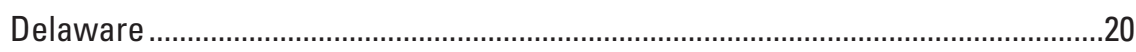

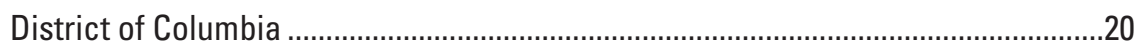

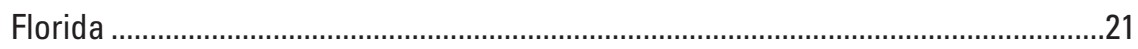

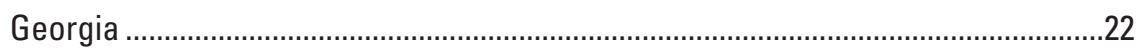

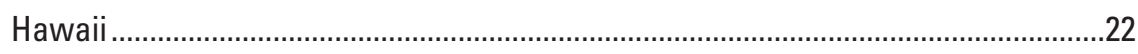

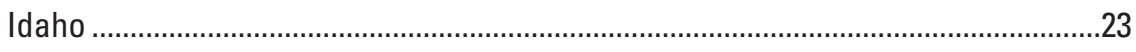

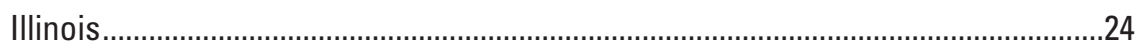

Indiana

lowa.

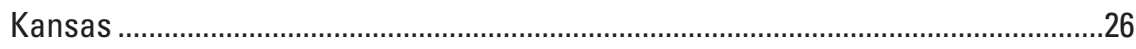

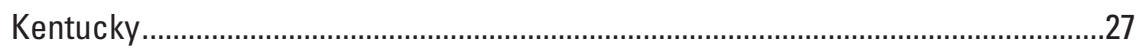

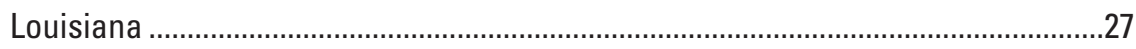

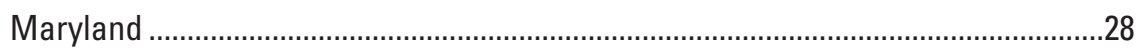

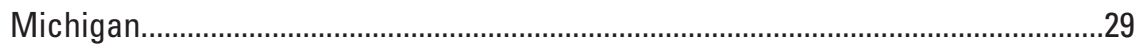

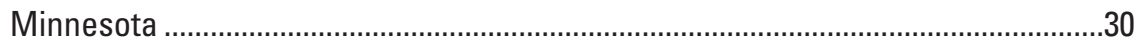

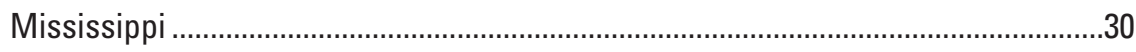

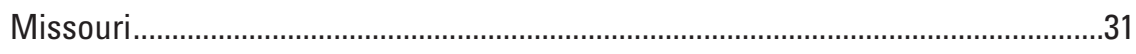

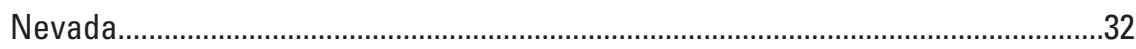




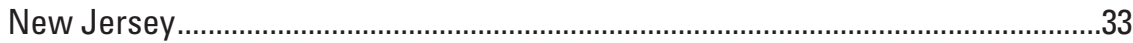

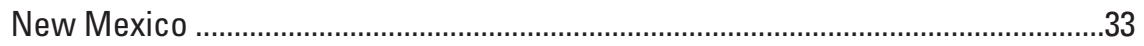

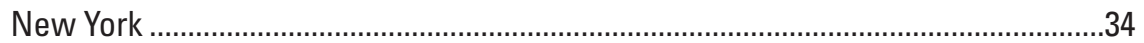

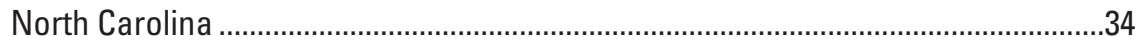

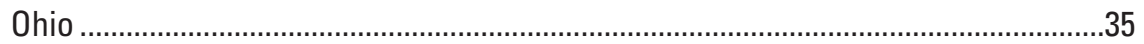

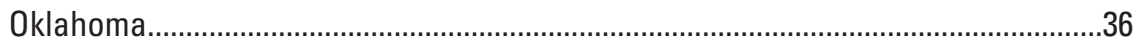

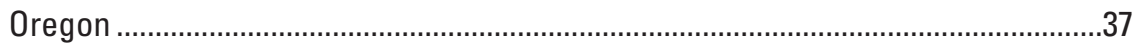

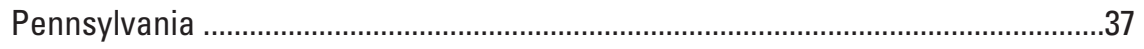

South Carolina ..................................................................................................

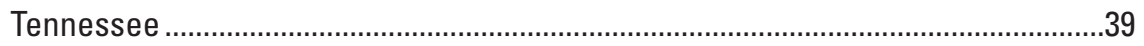

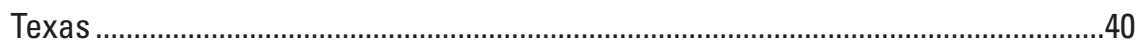

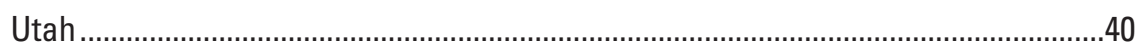

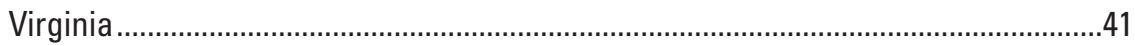

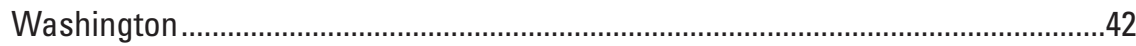

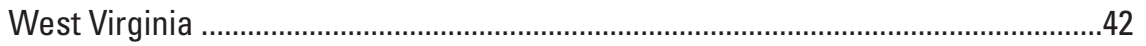

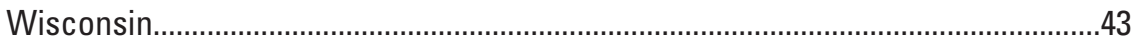

Other Corbicula Species and Forms in the United States.................................................44

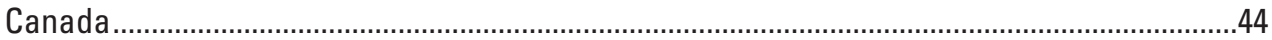

Mexico, Central America, and Caribbean ...........................................................................4

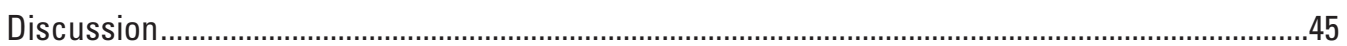

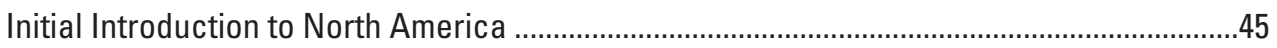

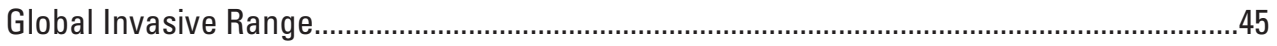

Invasive Characteristics and Dispersal ..........................................................................4

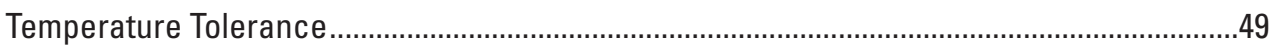

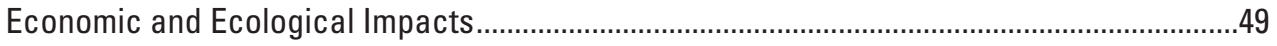

Prevention, Management and Control, Eradication...................................................................50

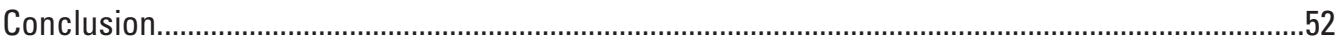

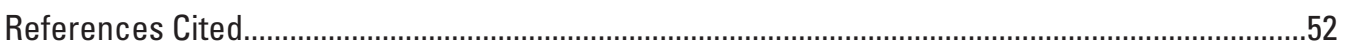

\section{Figures}

1. Photograph showing Corbicula fluminea collected in 1937, Willapa River, Raymond, Washington.

2. Photograph showing Corbicula sp. collected in Colquitt County, Georgia ..........................3

3. Map showing Corbicula spp. presence in 8-digit hydrologic unit code (HUC8) subbasins in the United States from 1937 to 1984 and from 1985 to 2019 ..........................6

4. Map showing Corbicula spp. occurrence locations in North America from 1924 to 1984 and 1985 to 2019 .

5. Graph showing numbers of 8-digit hydrologic unit code (HUC8) subbasins in the United States with Corbicula spp. occurrences by State prior to 1985 and from 1985 to 2019.

6. Graph showing numbers of counties in the United States with Corbicula spp.

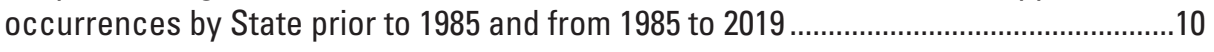

7. Map showing Corbicula spp. occurrences in Colorado through 2019 ............................11

8. Map showing Corbicula spp. occurrences in Connecticut through 2019......................12

9. Map showing Corbicula spp. occurrences in Massachusetts through 2019...................12 
10. Map showing Corbicula spp. occurrences in Montana through 2019 ............................13

11. Map showing Corbicula spp. occurrences in Nebraska through 2019 ...........................13

12. Map showing Corbicula spp. occurrences in New Hampshire through 2019..................14

13. Map showing Corbicula spp. occurrences in Puerto Rico through 2019.........................14

14. Map showing Corbicula spp. occurrences in Rhode Island through 2019 ......................15

15. Map showing Corbicula spp. occurrences in South Dakota through 2019 ......................15

16. Map showing Corbicula spp. occurrences in Vermont through 2019...............................16

17. Map showing Corbicula spp. occurrences in Wyoming through 2019.............................16

18. Map showing Corbicula spp. occurrences in Alabama through 2019............................17

19. Map showing Corbicula spp. occurrences in Arizona through 2019.............................18

20. Map showing Corbicula spp. occurrences in Arkansas through 2019..........................19

21. Map showing Corbicula spp. occurrences in California through 2019 ..........................19

22. Map showing Corbicula spp. occurrences in Delaware through 2019 ...........................20

23. Map showing Corbicula spp. occurrences in the District of Columbia through 2019.....21

24. Map showing Corbicula spp. occurrences in Florida through 2019 ..............................21

25. Map showing Corbicula spp. occurrences in Georgia through 2019 ............................22

26. Map showing Corbicula spp. occurrences in Hawaii through 2019 ...............................22

27. Map showing Corbicula spp. occurrences in Idaho through 2019 .................................23

28. Map showing Corbicula spp. occurrences in Illinois through 2019...............................24

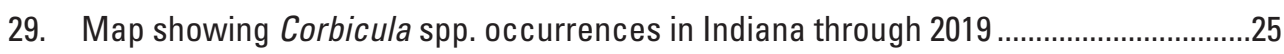

30. Map showing Corbicula spp. occurrences in lowa through 2019.................................25

31. Map showing Corbicula spp. occurrences in Kansas through 2019 ..............................26

32. Map showing Corbicula spp. occurrences in Kentucky through 2019...........................27

33. Map showing Corbicula spp. occurrences in Louisiana through 2019 ............................28

34. Map showing Corbicula spp. occurrences in Maryland through 2019 ...........................29

35. Map showing Corbicula spp. occurrences in Michigan through 2019............................30

36. Map showing Corbicula spp. occurrences in Minnesota through 2019 ........................30

37. Map showing Corbicula spp. occurrences in Mississippi through 2019 ........................31

38. Map showing Corbicula spp. occurrences in Missouri through 2019............................32

39. Map showing Corbicula spp. occurrences in Nevada through 2019..............................32

40. Map showing Corbicula spp. occurrences in New Jersey through 2019........................33

41. Map showing Corbicula spp. occurrences in New Mexico through 2019........................33

42. Map showing Corbicula spp. occurrences in New York through 2019............................34

43. Map showing Corbicula spp. occurrences in North Carolina through 2019 ....................35

44. Map showing Corbicula spp. occurrences in Ohio through 2019 ...................................35

45. Map showing Corbicula spp. occurrences in Oklahoma through 2019............................36

46. Map showing Corbicula spp. occurrences in Oregon through 2019 ...............................37

47. Map showing Corbicula spp. occurrences in Pennsylvania through 2019.....................38

48. Map showing Corbicula spp. occurrences in South Carolina through 2019 ....................38

49. Map showing Corbicula spp. occurrences in Tennessee through 2019 .........................39

50. Map showing Corbicula spp. occurrences in Texas through 2019 ................................40

51. Map showing Corbicula spp. occurrences in Utah through 2019 ....................................41

52. Map showing Corbicula spp. occurrences in Virginia through 2019..............................41

53. Map showing Corbicula spp. occurrences in Washington through 2019 .......................42

54. Map showing Corbicula spp. occurrences in West Virginia through 2019......................43 
55. Map showing Corbicula spp. occurrences in Wisconsin through 2019.........................43

56. Photograph showing Corbicula for sale in Hawaii at a live food market in 2019.............46

57. Photographs showing Corbicula for sale in Georgia and Texas food

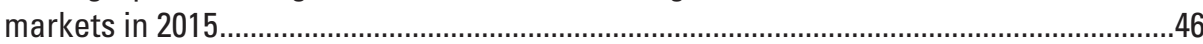

58. Maps showing Corbicula spp. occurrences over time in the United States...................48

\section{Table}

1. Year of first reported Corbicula spp. occurrence in a U.S. State, District of Columbia, and Puerto Rico in chronological order and the associated 6-digit hydrologic unit code (HUC6) basin

\section{Conversion Factors}

U.S. customary units to International System of Units

\begin{tabular}{|c|c|c|}
\hline Multiply & By & To obtain \\
\hline \multicolumn{3}{|c|}{ Length } \\
\hline mile (mi) & 1.609 & kilometer $(\mathrm{km})$ \\
\hline \multicolumn{3}{|c|}{ Area } \\
\hline acre & 0.4047 & hectare (ha) \\
\hline square foot $\left(\mathrm{ft}^{2}\right)$ & 0.09290 & square meter $\left(\mathrm{m}^{2}\right)$ \\
\hline square mile $\left(\mathrm{mi}^{2}\right)$ & 259.0 & hectare (ha) \\
\hline
\end{tabular}

International System of Units to U.S. customary units

\begin{tabular}{|c|c|c|}
\hline Multiply & By & To obtain \\
\hline \multicolumn{3}{|c|}{ Length } \\
\hline centimeter $(\mathrm{cm})$ & 0.3937 & inch (in.) \\
\hline millimeter (mm) & 0.03937 & inch (in.) \\
\hline meter (m) & 3.281 & foot $(\mathrm{ft})$ \\
\hline kilometer (km) & 0.6214 & mile (mi) \\
\hline kilometer $(\mathrm{km})$ & 0.5400 & mile, nautical (nmi) \\
\hline meter (m) & 1.094 & yard (yd) \\
\hline \multicolumn{3}{|c|}{ Area } \\
\hline square meter $\left(\mathrm{m}^{2}\right)$ & 0.0002471 & acre \\
\hline hectare (ha) & 2.471 & acre \\
\hline square kilometer $\left(\mathrm{km}^{2}\right)$ & 247.1 & acre \\
\hline square meter $\left(\mathrm{m}^{2}\right)$ & 10.76 & square foot $\left(\mathrm{ft}^{2}\right)$ \\
\hline hectare (ha) & 0.003861 & square mile $\left(\mathrm{mi}^{2}\right)$ \\
\hline square kilometer $\left(\mathrm{km}^{2}\right)$ & 0.3861 & square mile $\left(\mathrm{mi}^{2}\right)$ \\
\hline
\end{tabular}




\begin{tabular}{rcc}
\hline Multiply & By & To obtain \\
\hline & Mass & \\
\hline kilogram $(\mathrm{kg})$ & 2.205 & pound avoirdupois $(\mathrm{lb})$ \\
\hline
\end{tabular}

Temperature in degrees Celsius $\left({ }^{\circ} \mathrm{C}\right)$ may be converted to degrees Fahrenheit $\left({ }^{\circ} \mathrm{F}\right)$ as follows: ${ }^{\circ} \mathrm{F}=\left(1.8 \times{ }^{\circ} \mathrm{C}\right)+32$.

Temperature in degrees Fahrenheit $\left({ }^{\circ} \mathrm{F}\right)$ may be converted to degrees Celsius $\left({ }^{\circ} \mathrm{C}\right)$ as follows: ${ }^{\circ} \mathrm{C}=\left({ }^{\circ} \mathrm{F}-32\right) / 1.8$.

\section{Datum}

Datum is World Geodetic System 1984 (WGS 84). 


\title{
Review of the Invasive Asian Clam Corbicula spp. (Bivalvia: Cyrenidae) Distribution in North America, 1924-2019
}

\author{
By Amy J. Benson'1 and James D. Williams²
}

\section{Abstract}

The bivalve Corbicula is one of the most successful aquatic mollusk invaders in the world. Since being introduced to North America from its native range in Asia, it has dispersed widely over a large portion of the continent from southern Canada to Panama. The first evidence of its introduction in the Western Hemisphere was discovered in 1924 in British Columbia, Canada. A review of distribution records from natural history museums, scientific literature, Federal and State agencies, universities, and oral and written communications with scientists has shown the continued dispersal of Corbicula in North America. Since the most recent comprehensive review of its distribution information through the mid1980s, Corbicula has been found in an additional 2 Canadian Provinces, 10 U.S. States and Puerto Rico, 9 Mexican States, Cuba, and Panama. The known distribution in North America now includes 47 U.S. States, District of Columbia, Puerto Rico, 3 Canadian Provinces, 16 Mexican States, Cuba, and Panama. Corbicula has been found in three of the Laurentian Great Lakes (Erie, Michigan, Superior) primarily associated with industrial warmwater effluent refugia. Problems associated with Corbicula populations were widely realized not long after its arrival and included negative impacts to power generation, industrial water supply operations, and agricultural water conveyance. In natural settings, impacts on native mussels such as altering nutrient cycling, food webs, and sediment distribution dynamics have occurred. In past decades, control of established open water populations had not been a management priority. With a relatively recent interest in eradication of small, newly established populations, several attempts were made in the United States but were unsuccessful. Recent molecular genetic analyses provide evidence of multiple species and (or) genetically and morphologically distinguishable "forms" in North America. However, the number and identification of Corbicula species in North America remains unresolved. It appears likely that more than one species of Corbicula has been introduced into U.S. waters.

\footnotetext{
1U.S. Geological Survey.
}

\section{Introduction}

Genus Corbicula, commonly referred to as either the "Asian Clam" or "Asiatic Clam," comprises some of the most successful invasive mollusk species in aquatic ecosystems of its invaded range around the world (Sousa and others, 2008). The concern over the presence of Corbicula in its invaded range is twofold. It is notorious for its biofouling capabilities in industrial settings (Morton, 1979b; McMahon, 1982; Page and others, 1986) and for its ecological impacts in natural environments (Phelps, 1994; Strayer, 1999; Pigneur and others, 2014; Sousa and others, 2014). The purpose of this review is to present an updated distribution of Corbicula in North America since the compilation of Counts (1991), in which 1984 was the last year of included collection and occurrence records. Since 1984, Corbicula has continued to disperse into previously uninhabited river systems throughout much of the United States and subtropical North America. In Canada, its distribution has increased but remains limited to southern British Columbia and the Great Lakes Basin. Documentation of its dispersal is increasingly important because of the recent discovery in the upper Mississippi River Basin of populations of genetically distinct "forms" with distinctive color patterns (Tiemann and others, 2017), which may prove to be more invasive than the widespread species identified as Corbicula fluminea (O. F. Müller, 1774).

Corbicula was introduced from temperate and subtropical areas of southeastern Asia to North America, where a population was first noted in the literature with a collection made from the Columbia River in Washington State in 1938 (Burch, 1944). However, the earliest known specimens of Corbicula in North America were actually collected on Vancouver Island, British Columbia, Canada, in 1924 (Counts, 1981). This collection, discovered at the National Museum of Natural History and consisted only of empty shells, was not revealed to the larger scientific community until nearly six decades later (Counts, 1981). Similar to the 1924 collection in British Columbia that went unnoticed for decades, a collection made in the United States in 1937 at Raymond, Washington (LACM 64359; fig. 1), was uncovered in 1984, predating the 1938 


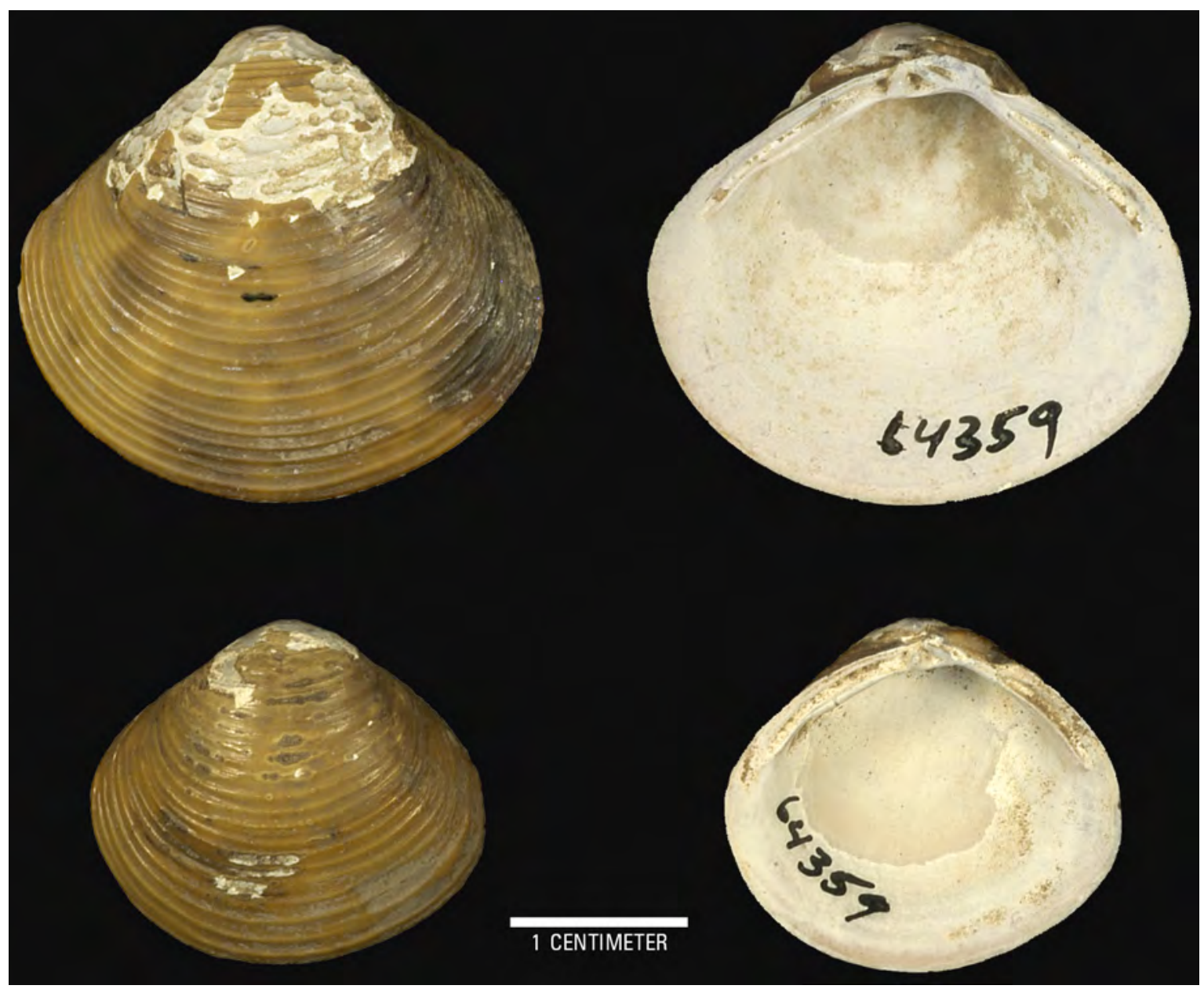

Figure 1. Corbicula fluminea collected in 1937, Willapa River, Raymond, Washington (Natural History Museum of Los Angeles County [LACM 64359]). The shell shown at top measures 30 millimeters in length, and the shell shown at bottom measures 22 millimeters in length. Photograph by Lindsey Groves, Natural History Museum of Los Angeles County, 2020; used with permission.

collection by 1 year (Counts, 1985a). A founding population in the region likely arrived sometime from the early 1920 s (Counts, 1981) to the mid-1930s (Britton and Morton, 1979).

After establishment in Washington State, Corbicula dispersed southward to Oregon and California in the early 1940s then eastward to Arizona by the mid-1950s (Counts, 1981, 1986, 1991; McMahon, 1982). The earliest collection of Corbicula east of the Continental Divide occurred in 1957 where seemingly isolated specimens were found in the Ohio River (Mississippi River drainage) near Paducah, Kentucky (Sinclair and Isom, 1961). The Kentucky collection was then followed by the first collections in Texas and New Mexico (Gulf of Mexico drainage) in 1958 and 1964, respectively (Metcalf, 1966; Howells and others, 2004). The earliest collection of Corbicula from an Atlantic Coast drainage was in 1963 from the Navesink River in New Jersey. Over the next several decades, Corbicula dispersed predominantly throughout the southeastern United States. In past summaries, collection records were found and compiled from 28 States and District of Columbia by 1980 (Counts, 1981), 34 States and District of Columbia by about 1983 (Counts, 1986), and lastly from 37 States and District of Columbia by 1984 (Counts, 1991).

\section{Identification and Biology}

The senior family name Cyrenidae is now in use and is synonymous with the more familiar junior name Corbiculidae (Bieler and others, 2010). In North America, Cyrenidae is represented by two genera, the native Polymesoda and the introduced (nonindigenous) Corbicula, and includes freshwater, estuarine, and marine bivalves. In addition to Cyrenidae, there are four other families of native bivalves found in freshwater habitats in North America. The largest (attaining lengths of nearly 30 centimeters $[\mathrm{cm}]$ ) and most recognizable of these bivalves are the native freshwater mussels of 
the families Margaritiferidae and Unionidae, of which there are 298 species in 55 genera in the United States and Canada (Williams and others, 2017). Corbicula is easily distinguished from freshwater mussels by its smaller size and its serrated lateral teeth on each side of the cardinal tooth located on the dorsal margin of the shell (fig. 2). Native freshwater mussels have a single nonserrated lateral tooth posterior to the pseudocardinal tooth, or in some genera teeth are greatly reduced (for example, Strophitus) or absent (for example, Pyganodon). Groups of bivalves more easily confused with Corbicula are the fingernail clams and pea clams both of the native family Sphaeriidae in North America. These include small (length less than $3 \mathrm{~cm}$ ), thin-shelled bivalves that are widely distributed across the continent in a variety of habitats. Corbicula can be distinguished from sphaeriid clams by its thicker shell with prominent concentric ridges and serrated lateral teeth. Shells of sphaeriids are very thin, and the surface typically lacks well-developed ridges. The lateral teeth of sphaeriids are nonserrated. Other bivalves that have been confused with Corbicula are those in the family Dreissenidae. This family is represented in freshwater habitats of North America by four species, Mytilopsis leucophaeata (Conrad, 1831) (Dark Falsemussel) and Mytilopsis sallei (Recluz, 1849) (Santo Domingo Falsemussel), which are native, and Dreissena polymorpha (Pallas, 1771) (Zebra Mussel) and Dreissena rostriformis bugensis Andrusov, 1897 (Quagga Mussel), which are nonindigenous. The round to somewhat oval shell outline of Corbicula (fig. 1) distinguishes it from the triangular outline of the four species of native and introduced dreissenid mussels.

Corbicula is primarily a freshwater organism but can live in low salinity waters of 10-15 parts per thousand (ppt) (Morton, 1979a). Evans and others (1979) found large populations of Corbicula living in parts of the Sacramento-San Joaquin estuary with salinities from 10 to $12 \mathrm{ppt}$ and sparse populations in other parts with salinities as high as $17 \mathrm{ppt}$. Their high tolerance has been attributed to a relatively recent brackish water ancestry (Gainey and Greenberg, 1977). Corbicula is generally found in lotic habitats, but when found in lentic habitats it prefers littoral, shallow, and moderately eutrophic waters (McMahon, 1983, see references therein).

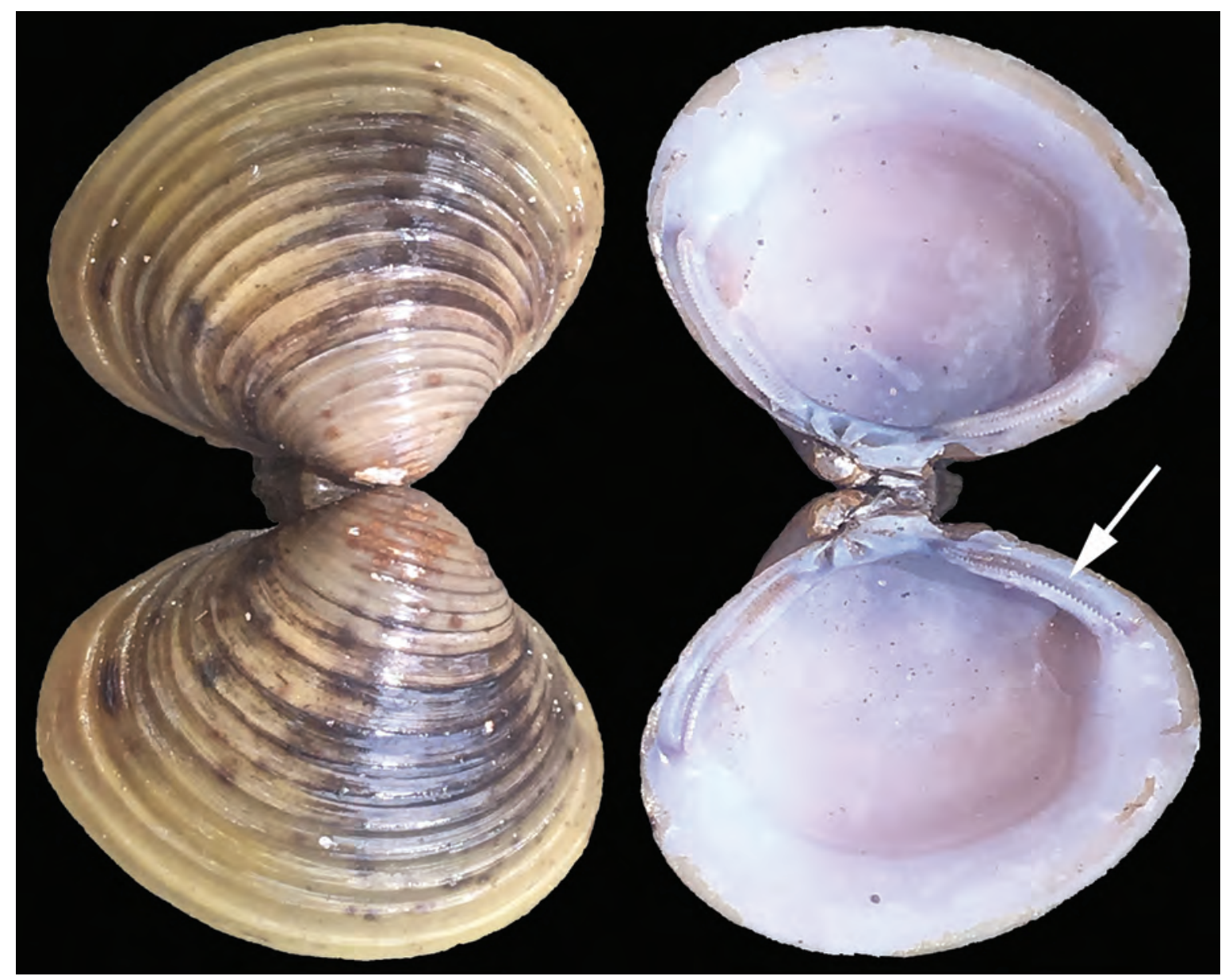

Figure 2. Corbicula sp. collected in Colquitt County, Georgia. Arrow indicates one of the serrated lateral teeth located along the dorsal margin of the shell, a diagnostic characteristic of the genus. Photograph copyright of Robin Gwen Agarwal, https://www.inaturalist.org/photos/4657053, licensed under the Creative Commons Attribution-NonCommercial 4.0 International (CC BY-NC 4.0) license. 
Review of the Invasive Asian Clam Corbicula spp. (Bivalvia: Cyrenidae) Distribution in North America, 1924-2019

It inhabits a variety of substrates ranging from mud, clay, and detritus to sand, gravel, and rocks (Gardner and others, 1976, see references therein); however, it appears to prefer fine sand (Sickel and Burbanck, 1974; Belanger and others, 1985). Corbicula is a filter feeder relying on algae, plankton, and bacteria suspended in the water column as its primary food sources (Cohen and others, 1984; Beaver and others, 1991; Boltovskoy and others, 1995). The maximum shell size of Corbicula in Asia is approximately 35 millimeters $(\mathrm{mm})$ (Britton and Morton, 1986) and in the United States is $50 \mathrm{~mm}$ (Eng, 1979). Individuals live 1-5 years, exhibit rapid growth, attain sexual maturity in the first year, and can spawn approximately 35,000 young in one breeding season (McMahon, 1991).

\section{Taxonomy}

The problematic nature of Corbicula taxonomy has resulted in reports recorded under several specific epithets (Hillis and Patton, 1982). The current prevailing binomial for the Asian Clam in scientific literature in the United States is $C$. fluminea. However, there are numerous reports of C manilensis (Philippi, 1844) and C. leana (Prime, 1867) in earlier literature and some museum collections. These two species are considered to be junior synonyms of $C$. fluminea (Morton, 1979a). Hillis and Patton (1982) used morphology and electrophoresis to conclude that two species, or forms, of Corbicula were introduced, but they were unable to assign names because of inadequate taxonomic studies in Asia. However, Britton and Morton (1986) concluded that there is evidence of only one species but two morphotypes in North America, "Form A," which is the prevalent form in the United States, and "Form B," known from the southwestern United States. Genetic evidence presented by Siripattrawan and others (2000) supports two lineages of Corbicula in North America. Collections of Form B have been made in the upper Mississippi River Basin beginning in 2008 and has recently been equated with $C$. largillierti (Philippi, 1841) (Illinois Natural History Survey, 2019; Douglass and others, 2020). A third form or clone, "Form C," was determined to be present in South America (Lee and others, 2005), which may or may not be the $C$. largillierti (Phillipi, 1844) identified by Ituarte (1994) in the early 1980s. On the basis of genetic evidence and morphological characteristics, a Corbicula lineage new to North America, "Form D," was determined from specimens collected in 2015 from the Illinois and Ohio Rivers (Tiemann and others, 2017, 2018). This new Form D was later confirmed as genetically distinct from Form A and Form B (Haponski and Ó Foighil, 2019). The problems associated with sorting Corbicula species by using molecular genetics are complicated by what appear to be exclusively asexual (for example, androgenic) clonal lineages in some populations, which greatly hinders taxonomic understanding (Tiemann and others,
2017). Because the taxonomy of the genus is still in need of clarification, all specimen records we compiled for this review will be referred to as "Corbicula" unless otherwise stated.

\section{Methods}

Two frequently cited publications for Corbicula distribution and dispersal in North America are Counts (1986) and Counts (1991). Counts (1986) is a summary of Corbicula zoogeography and history of the invasion, whereas Counts (1991) is a compilation of distribution records in North America and Hawaii based entirely on specimens housed in museum collections and reported in published scientific literature. As stated previously, the last year for inclusion of Corbicula records in Counts (1991) was 1984. Herein, any Corbicula specimens collected, vouchered and (or) observed and reported after 1984 are considered "new" records for this review. Collection records were electronically obtained for all years through December 2019 primarily from major museums throughout the United States. We determined that it was not feasible to visit all museums in person and therefore accepted the identifications made by collectors with few exceptions. While we were aware that errors do occur in the identification of museum specimens collected in the United States, the distinctive morphology and color of Corbicula greatly reduces the possibility of misidentification with native species. Occurrence records were also obtained from scientific literature and reports published after 1984, as well as the Global Biodiversity Information Facility (GBIF.org, 2020) and the Midwest Invasive Species Information Network (MISIN, 2019). Collections and observations through oral and written communications with natural resource agency and other individuals, most of which are unvouchered and unpublished, were included (Benson and Williams, 2021). Any additional records in unpublished scientific studies, unsorted and uncataloged museum collections, and private collections were not included in this review. We also recognize that this review likely underrepresents known and verified populations that exist in small habitats such as the many kettle lakes in northern States, as well as barrow pits, farm ponds, and various types of ditches throughout the United States. The following is a list of university and natural history museum collection acronyms housing vouchered Corbicula specimens used in this review:

AMNH - American Museum of Natural History, New

York, New York

ANSP - Academy of Natural Sciences of Drexel University, Philadelphia, Pennsylvania

AUM - Auburn University Museum of Natural History,

Auburn, Alabama

BMNSM - Bailey-Matthews National Shell Museum,

Sanibel, Florida

BPBM - Bernice Pauahi Bishop Museum, Honolulu, Hawaii 
CAS-IZ - California Academy of Sciences, Institute for Biodiversity Science and Sustainability, San Francisco, California

CMNH - Carnegie Museum of Natural History, Pittsburgh, Pennsylvania

CMN-ML - Canadian Museum of Nature, Ottawa, Canada

CR - Naturhistorisches Museum Mainz, Mainz, Germany

DMNH - Delaware Museum of Natural History,

Wilmington, Delaware

DMNS - Denver Museum of Nature and Science,

Denver, Colorado

FMNH - Field Museum of Natural History, Chicago, Illinois

HMNS.MAL - Houston Museum of Natural Science,

Houston, Texas

INHS - Illinois Natural History Survey, Champaign, Illinois

JFBM - James Ford Bell Museum of Natural History, St. Paul, Minnesota

LACM - Natural History Museum of Los Angeles County,

Los Angeles, California

MCZ - Museum of Comparative Zoology, Cambridge,

Massachusetts

MMNS - Mississippi Museum of Natural Science, Jackson,

Mississippi

NCSM - North Carolina Museum of Natural Sciences,

Raleigh, North Carolina

NPL - Non-vertebrate Paleontology Laboratory, University of

Texas at Austin, Austin, Texas

OMNH - Sam Noble Oklahoma Museum of Natural History,

University of Oklahoma, Norman, Oklahoma

OSUM -Museum of Biological Diversity, Ohio State

University, Columbus, Ohio

RBCM - Royal British Columbia Museum, Victoria, British

Columbia, Canada

TCU - Texas Christian University, Fort Worth, Texas (speci-

men collections not located; copy of TCU specimen collection ledger used in review)

UCM - Museum of Natural History, University of Colorado

Boulder, Boulder, Colorado

UF - Florida Museum of Natural History, University of

Florida, Gainesville, Florida

UMMZ - University of Michigan Museum of Zoology, Ann

Arbor, Michigan

USAO - University of Science and Arts of Oklahoma,

Chickasha, Oklahoma

USNM - National Museum of Natural History, Smithsonian Institution, Washington D.C.

UT - McClung Museum of Natural History and Culture,

University of Tennessee, Knoxville, Tennessee

UTEP - University of Texas at El Paso, El Paso, Texas

UWBM - Burke Museum of Natural History and Culture,

University of Washington, Seattle, Washington

YPM IZ - Yale Peabody Museum of Natural History, New

Haven, Connecticut.

This review provides an account of reported Corbicula

occurrences in the United States by following a format similar to Counts (1986). We also summarize available occurrence information for the rest of North America. In the following individual State, District, and Territory accounts of Corbicula collections and observations made after 1984, museum catalog numbers are provided for vouchered specimens. However, a large proportion of the waterbody names listed are not followed by museum catalog numbers. These represent the occurrence locations found in scientific literature, field observations, and oral and written communications and were too numerous to cite herein. However, they are credited and cited within the USGS Nonindigenous Aquatic Species (NAS) database, where these data are stored for public access (USGS, 2019). Duplicate waterbody names do exist in many if not all States and are not differentiated in this review. Specific locations of any waterbody where Corbicula was collected and duplicate names occur within a State, District, or Territory and its counties are available in the NAS database (USGS, 2019). Because Corbicula collections have been made from waterbodies that form State or District boundary lines, we acknowledge they are likely present within both jurisdictions. However, we report Corbicula only in the State, District, or Territory in which the collection or observation occurred. For any given waterbody with more than one collection, a museum voucher specimen was given priority for inclusion in this review over both scientific publications and unpublished data. In instances where vouchered collections were from the same waterbody but from different years and vouchered in multiple museums, the museum lot with the earliest date was included as the representative record for the waterbody. For comparison in distribution between collections that were prior to 1985 and after 1984, we list the majority of waterbodies provided in Counts (1991), followed by a list of waterbodies where collections were made for the first time after 1984 (this review) for each country and its States, Districts, Territories, or Provinces.

In an effort to standardize a summary of Corbicula distribution information for each U.S. State, District, or Territory, subbasin hydrologic units and counties were utilized. We chose the 8-digit hydrologic unit code (HUC8) subbasins, where the average size of a unit is approximately 700 square miles $\left(\mathrm{mi}^{2}\right)\left(1,813\right.$ square kilometers $\left.\left[\mathrm{km}^{2}\right]\right)$, to characterize the distribution of Corbicula. Each shaded HUC8 subbasin has a minimum of one waterbody with an occurrence (fig. 3). The subbasins are part of the USGS Watershed Boundary Dataset which contains a hierarchy of watershed delineations (USGS and U.S. Department of Agriculture [USDA], 2013). There are approximately 2,297 HUC 8 subbasins and 3,141 counties and county equivalents in the 50 U.S. States, District of Columbia, and Puerto Rico. Most, if not all, States and District of Columbia contain extremely small portions of HUC8 subbasins that fall primarily in the neighboring State or District of Columbia and are included in the total number of HUC8 subbasins for each State or District of Columbia. The number of HUC8 subbasins and counties with occurrence records are provided for each State, District of Columbia, and Puerto Rice. Individual maps are provided; maps are also included and updated in real time in the USGS NAS database (USGS, 2019). 


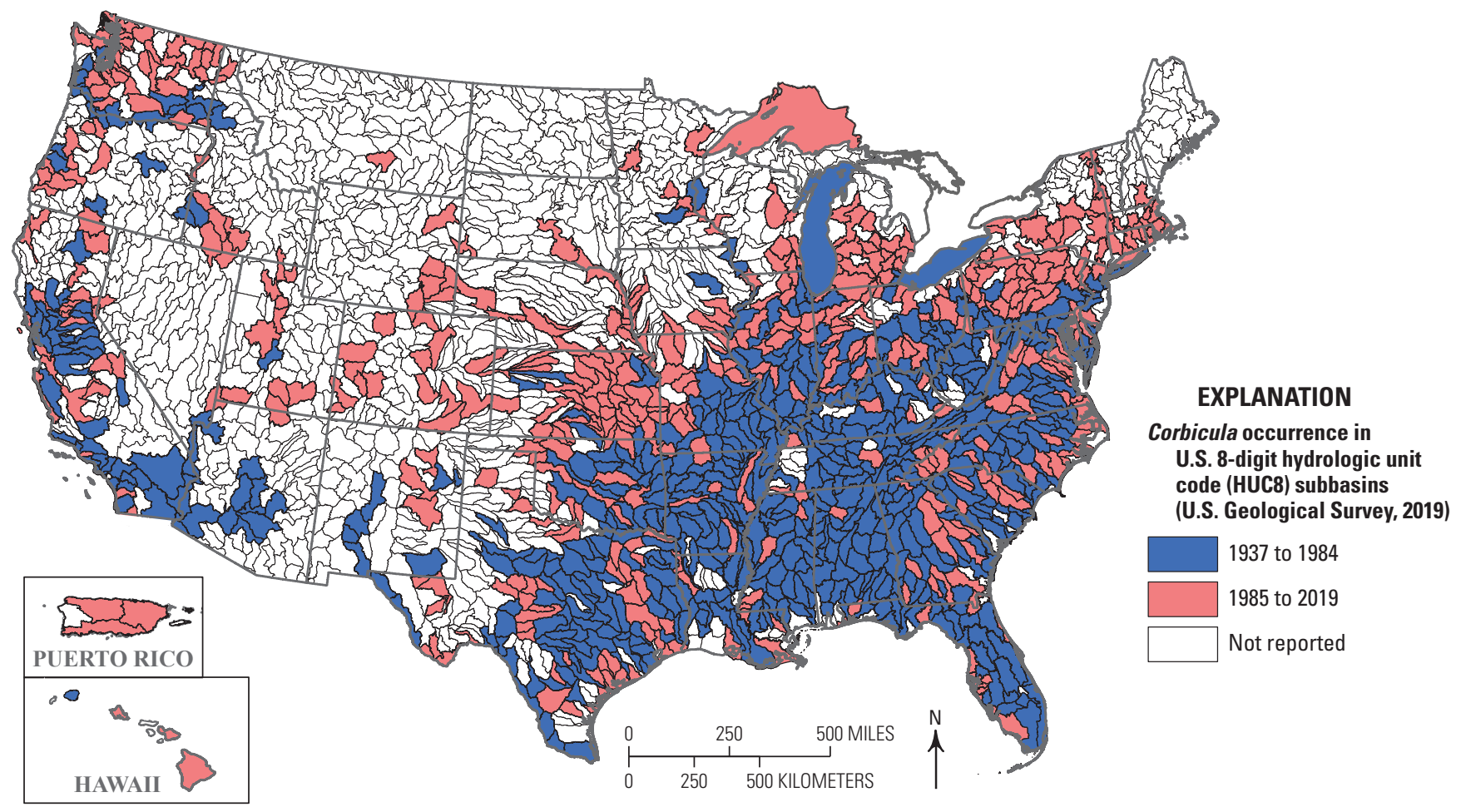

Figure 3. Corbicula spp. presence in 8-digit hydrologic unit code (HUC8) subbasins in the United States from 1937 to 1984 and from 1985 to 2019.

\section{Results}

\section{United States}

The distribution of Corbicula collection locations in the United States through 2019 includes 47 States, the District of Columbia, and Puerto Rico (USGS, 2019) (table 1; fig. 4). We found new vouchered collections and reported observations made for the first time in 10 States and Puerto Rico during the period from 1985 to 2019 . These most recently invaded areas were those where Corbicula was initially not expected to survive in a temperate climate and included the northern Great Plains, Great Lakes, and New England regions. In order of appearance based on the first year of collection or observation, the 10 States and 1 Territory are Connecticut (1990), Nebraska (1991), Colorado (1993), Puerto Rico (1998), Rhode Island (1999), Massachusetts (2001), South Dakota (2004), Wyoming (2011), New Hampshire (2012), Vermont (2016), and Montana (2019). There were only three States, Alaska, Maine, and North Dakota, where no occurrence information or vouchered museum specimens could be found for any year. The number of waterbodies with occurrences of Corbicula for the first time after 1984 varied widely, from the State of Connecticut with just two waterbodies to States with hundreds each that included Georgia (290), Illinois (192), North Carolina (396), and Virginia (360). For comparison over the entire United States, Corbicula was found in 556 HUC8 subbasins prior to 1985 and in an additional 478 HUC8 subbasins from 1985 to
2019 for a total of 1,034 out of 2,297 HUC8 subbasins (fig. 5). While the number of HUC8 subbasins with occurrences prior to 1985 (Counts 1991) did not increase greatly after 1984 (this review), the number of additional streams after 1984 with firsttime occurrences within those subbasins did increase considerably (fig. 3). That is to say, Corbicula continued to disperse in subbasins after 1984 where they were found prior to 1985 . The number of counties with Corbicula occurrences prior to 1985 was approximately 619. From 1985 to 2019, 534 additional counties were added for a total of 1,153 out of 3,141 (fig. 6). In the Great Lakes, Corbicula had been collected for the first time from Lake Erie and Lake Michigan in 1980 and 1983, respectively, with Lake Superior having its first collection made in 1994. We found no Corbicula collections vouchered or observations reported for Lake Huron or Lake Ontario. The number of reported occurrences in the Great Lakes has been limited, with most being in the vicinity of industrial thermal (that is, warmwater) effluent refugia along lake shorelines.

In our search we found Corbicula collection records with collection dates earlier than 1985, primarily from museums, that were not included in Counts (1991). We considered these museum vouchers to be significant additions of Corbicula occurrences prior to 1985 that were either acquired or assigned catalog numbers after 1984. The majority of these collections were found in the Ohio State University Museum of Biological Diversity (OSUM), North Carolina Museum of Natural Sciences (NCSM: H.D. Athearn collection), Delaware Museum of Natural History (DMNH), and Mississippi 
Table 1. Year of first reported Corbicula spp. occurrence in a U.S. State, District of Columbia, and Puerto Rico in chronological order and the associated 6-digit hydrologic unit code (HUC6) basin.

[HUC6 basins are used in this table for familiarity of the larger basin name. There is a total of 386 HUC6s in the United States (U.S. Geological Survey and U.S. Department of Agriculture, 2013). States without occurrences are also included. N/A, not applicable]

\begin{tabular}{|c|c|c|c|c|c|c|c|}
\hline State & $\begin{array}{l}\text { Year first } \\
\text { reported }\end{array}$ & HUC6 & HUC6 name & State & $\begin{array}{l}\text { Year first } \\
\text { reported }\end{array}$ & HUC6 & HUC6 name \\
\hline Washington & 1937 & 171001 & Washington Coastal & Pennsylvania & 1972 & 020402 & Lower Delaware \\
\hline Oregon & 1943 & 170800 & Lower Columbia & Iowa & 1974 & 070600 & $\begin{array}{l}\text { Upper Mississippi- } \\
\text { Maquoketa-Plum }\end{array}$ \\
\hline California & 1945 & 180500 & Suisun Bay & Maryland & 1975 & $\begin{array}{l}020503 \\
020600\end{array}$ & $\begin{array}{l}\text { Lower Susquehanna, Upper } \\
\text { Chesapeake }\end{array}$ \\
\hline Arizona & 1955 & 150301 & Lower Colorado & New York & 1977 & 020302 & Long Island \\
\hline Idaho & 1955 & 170501 & Middle Snake-Boise & Wisconsin & 1977 & 070300 & St. Croix \\
\hline Kentucky & 1957 & 051402 & Lower Ohio & District of Columbia & 1978 & 020700 & Potomac \\
\hline Texas & 1958 & 120200 & Neches & Minnesota & 1978 & 070200 & Minnesota \\
\hline Nevada & 1959 & 150100 & Lower Colorado-Lake Mead & Utah & 1978 & 160300 & Escalante Desert-Sevier Lake \\
\hline Tennessee & 1959 & 060400 & Lower Tennessee & Michigan & 1980 & 041202 & Lake Erie \\
\hline Alabama & 1960 & 060300 & Middle Tennessee-Elk & Delaware & 1981 & 020801 & Lower Chesapeake \\
\hline Florida & 1960 & 031403 & Escambia & Hawaii & 1982 & 020700 & Hawaii \\
\hline Illinois & 1960 & 051402 & Lower Ohio & Kansas & 1983 & $\begin{array}{c}102600, \\
102701, \\
110300\end{array}$ & $\begin{array}{l}\text { Smoky Hill, Kansas, Middle } \\
\text { Arkansas }\end{array}$ \\
\hline Louisiana & 1961 & 080802 & Calcasieu-Mermentau & Connecticut & 1990 & 010802 & Lower Connecticut \\
\hline Missouri & 1961 & 071100 & Upper Mississippi-Salt & Colorado & 1991 & 101900 & South Platte \\
\hline Ohio & 1962 & 050902 & Middle Ohio-Little Miami & Nebraska & 1991 & $\begin{array}{l}102001 \\
102002\end{array}$ & Middle Platte, Lower Platte \\
\hline Mississippi & 1963 & 031800 & Pearl & Puerto Rico & 1998 & 210100 & Puerto Rico \\
\hline New Jersey & 1963 & 020301 & Lower Hudson & Massachusetts & 1999 & 011000 & Connecticut Coastal \\
\hline West Virginia & 1963 & 050500 & Kanawha & Rhode Island & 1999 & 010900 & $\begin{array}{l}\text { Massachusetts-Rhode Island } \\
\text { Coastal }\end{array}$ \\
\hline Arkansas & 1964 & 080203 & Lower White & South Dakota & 2004 & 101701 & Lewis and Clark Lake \\
\hline Indiana & 1964 & 051402 & Lower Ohio & New Hampshire & 2007 & 010700 & Merrimack \\
\hline New Mexico & 1964 & 130301 & Rio Grande-Caballo & Wyoming & 2011 & 101800 & North Platte \\
\hline Georgia & 1967 & 031300 & Apalachicola & Vermont & 2016 & 041504 & $\begin{array}{l}\text { Lake Champlain-Richelieu } \\
\text { River }\end{array}$ \\
\hline South Carolina & 1968 & 030501 & Santee & Montana & 2019 & 100700 & Upper Yellowstone \\
\hline North Carolina & 1969 & 030501 & Santee & Alaska & N/A & N/A & N/A \\
\hline Oklahoma & 1969 & 111003 & Lower North Canadian & Maine & N/A & N/A & N/A \\
\hline Virginia & 1971 & 020802 & James & North Dakota & N/A & N/A & N/A \\
\hline
\end{tabular}




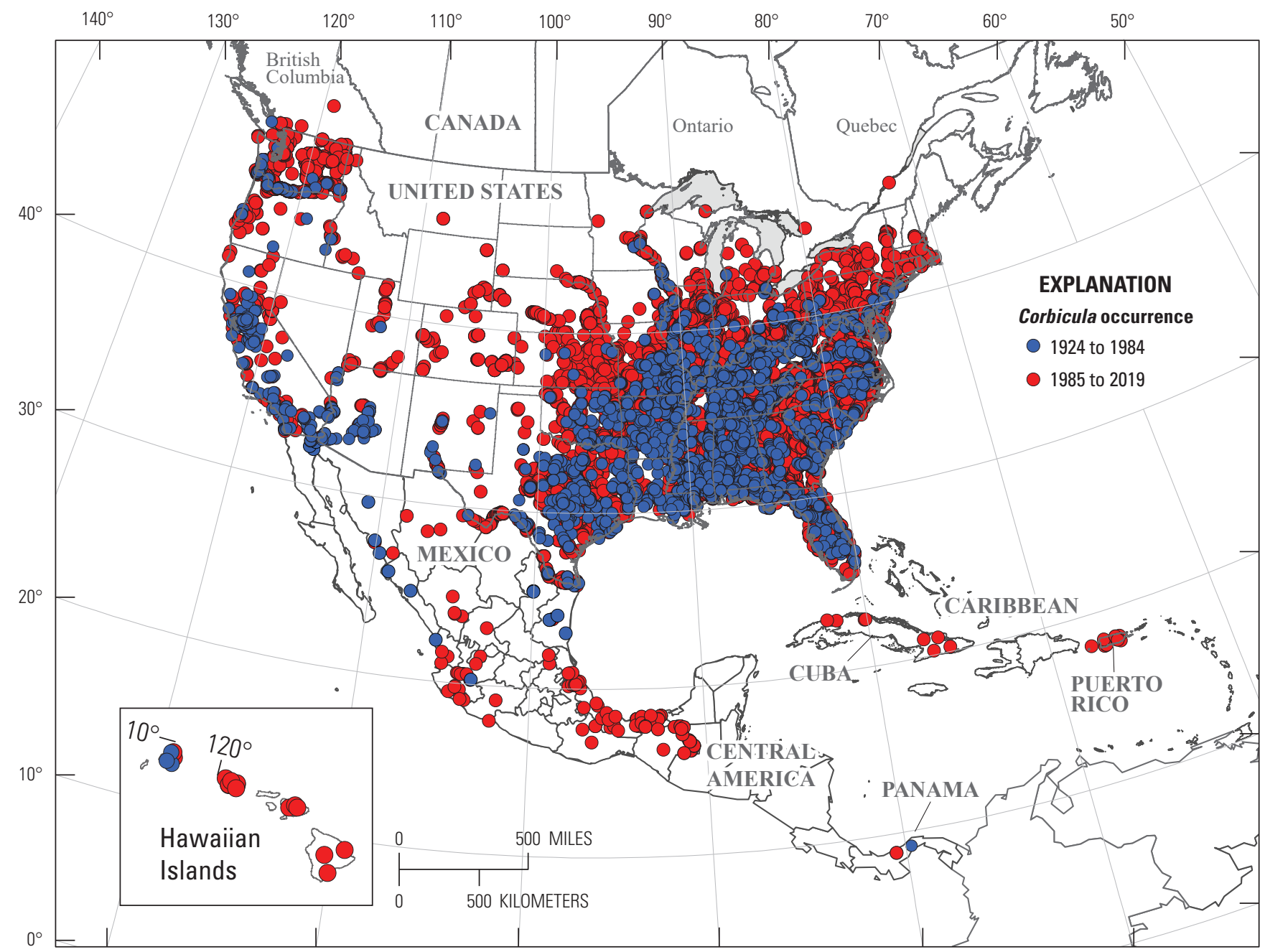

Figure 4. Corbicula spp. occurrence locations in North America from 1924 to 1984 and 1985 to 2019. Occurrence data for the United States from U.S. Geological Survey (2019). Occurrence data for Mexico from López and others (2019). Occurrence data for Cuba from Fernandez and others (2015) and Milera and Quiros (1995). Alaska not shown because of lack of occurrences.

Museum of Natural History (MMNS). In addition, we found a large number of collection records from 1977 to 1998 at the University of Science and Arts of Oklahoma (USAO) that were also not included in Counts (1991). A smaller proportion of additional "new" pre-1985 collection records came from publications and oral and written communications and are listed in the following accounts of each State in which the collections occurred. In reference to the Counts (1991) compilation, an earlier date for the first collection of Corbicula in a State was discovered through museum voucher specimens for Georgia, Idaho, Mississippi, Missouri, and New Jersey and is discussed in its respective State account.

In the process of this review, we uncovered an issue involving museum voucher specimen numbers associated with the California Academy of Sciences (CAS) Institute for Biodiversity Science and Sustainability collections reported in Counts $(1986,1991)$. While searching the CAS collections, we learned that the "catalog" numbers reported in Counts $(1986,1991)$ were actually accession numbers from the CAS Geology (GE) collection and not standard catalog numbers. In the past, mollusk shells were accessioned as part of the geology collection at the CAS. To avoid confusion, the museum has changed from using the CAS acronym for mollusks to CAS-IZ and assigned official catalog numbers. For example, in Counts (1991), the highly cited Corbicula record in 1938 from Washington State (CAS 32070) is now CAS-IZ 219729 while maintaining the accession number $32070 \mathrm{GE}$ for internal purposes. Regarding another set of collections, we were unsuccessful in locating the specimens cited in Counts (1991) as "TCU" (Texas Christian University). However, we acquired a copy of the TCU specimen collection ledger with the cited TCU catalog numbers for Corbicula from Texas A\&M University (Charles Randklev, Texas A\&M University, written commun., 2018). 


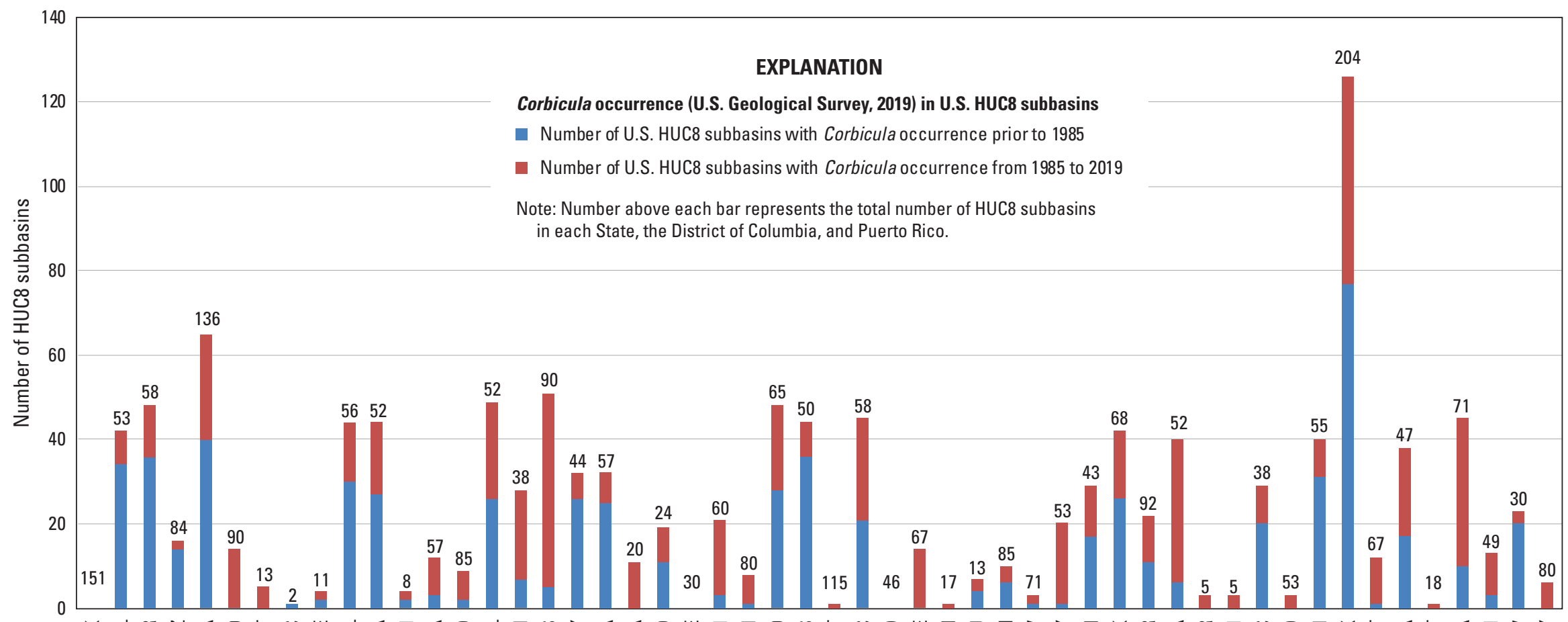

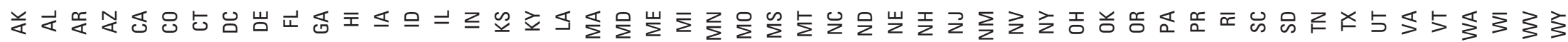

State

Figure 5. Numbers of 8-digit hydrologic unit code (HUC8) subbasins in the United States with Corbicula spp. occurrences by State prior to 1985 and from 1985 to 2019 . Number above each bar represents the total number of HUC8 subbasins in each State, the District of Columbia, and Puerto Rico. 


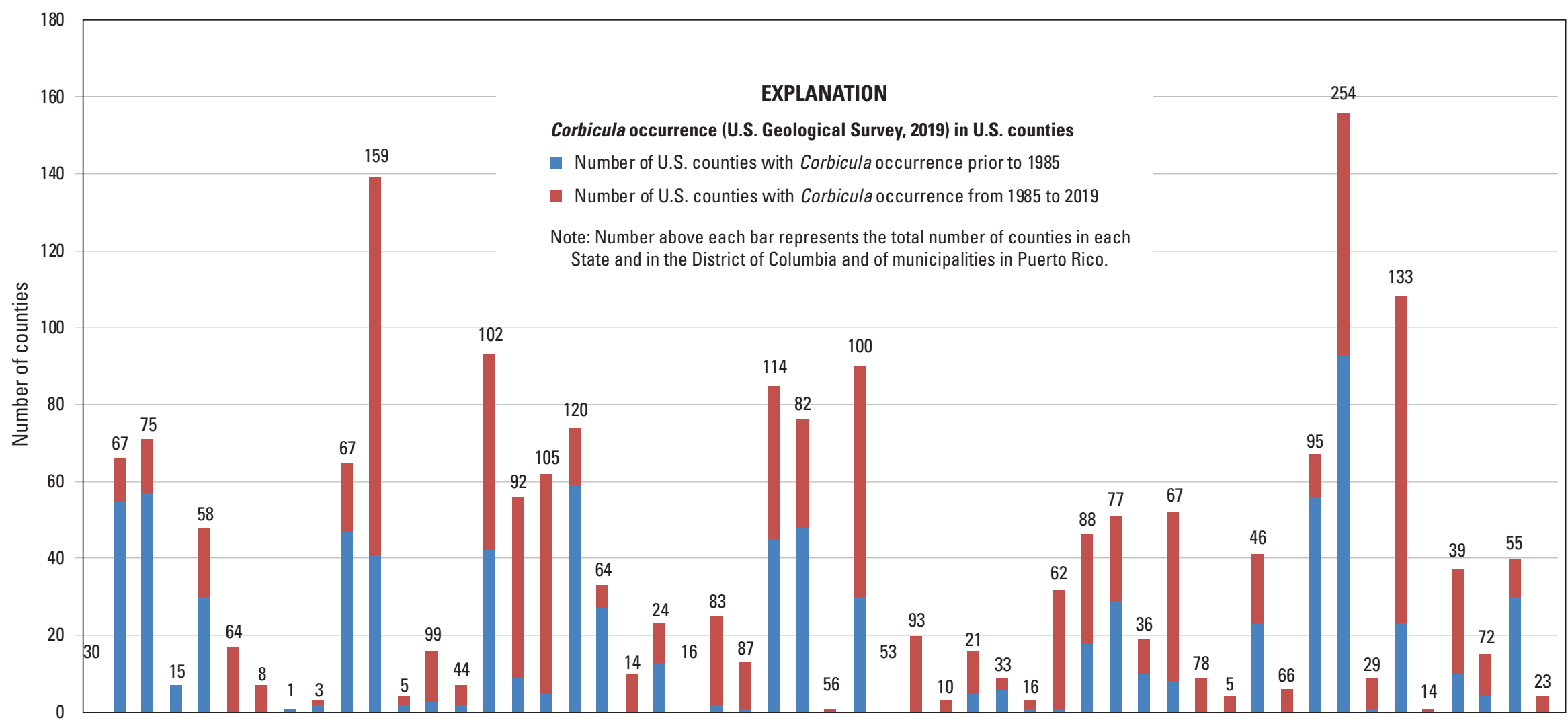

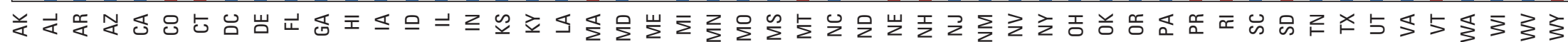

State

Figure 6. Numbers of counties in the United States with Corbicula spp. occurrences by State prior to 1985 and from 1985 to 2019. Number above each bar represents the total number of counties in each State and in the District of Columbia and of municipalities in Puerto Rico. 
State, District, and Territory accounts are presented in alphabetical order in the sections below.

\section{States and Territories With First Occurrence of Corbicula Post-1984}

\section{Colorado}

In 1991, Corbicula was discovered in Colorado at Cherry Creek Reservoir in Denver (UCM 41066), the earliest collection reported in the State. Two years later, Nelson and McNabb (1994) reported it as a reproducing population at a density of 32 individuals per square meter. By 1994, Corbicula was collected from waters both east and west of the Continental Divide near the borders with neighboring States of Kansas and Utah, respectively. Through field surveys and literature reviews, Cordeiro and others (2007) reported the expansion of Corbicula west of the divide predominantly in the Colorado River drainage headwaters (Highline Lake, House Creek, Salt Creek, Spring Creek) and Gunnison River, including Whitewater Creek. In 2003, a collection was made in the Colorado River near Grand Junction in the southwest part of the State. Two additional southwest collection locations include Rocky Ford Ditch at Totten Lake (UCM 47588) in 2007 and Uncompahgre River at Ridgway Reservoir in 2009 (UCM 47303). The only reported occurrence of Corbicula in the northwest region of the State was from the Yampa River in 2004 (UCM 46015). East of the divide, Corbicula was found in Pueblo and John Martin Reservoirs, both in 1996, and Purgatoire River of the upper Arkansas River drainage in southeastern Colorado in 2001. Cordeiro and others (2007) also reported Corbicula from the Republican drainage at Bonny Reservoir and the Great Plains reservoir system in Neegronda, Neenoshe, and Neeskah Reservoirs. These latter three waterbodies are a small group of natural depressions that were modified to store water for irrigation and water from the Arkansas River via an interconnected system of canals. Of the four major river drainages in Colorado, Corbicula has been found in the Arkansas, Colorado, and Missouri Rivers but not the Rio Grande. One possible source for its presence in open waters of the State is that in 1996 Corbicula was observed for sale in a Denver pet store (Cordeiro and MacWilliams, 1999). On the basis of this review, Corbicula has been found in 14 of 90 HUC8 subbasins and 17 of 64 counties in Colorado (figs. 3 , 5,6 , and 7).

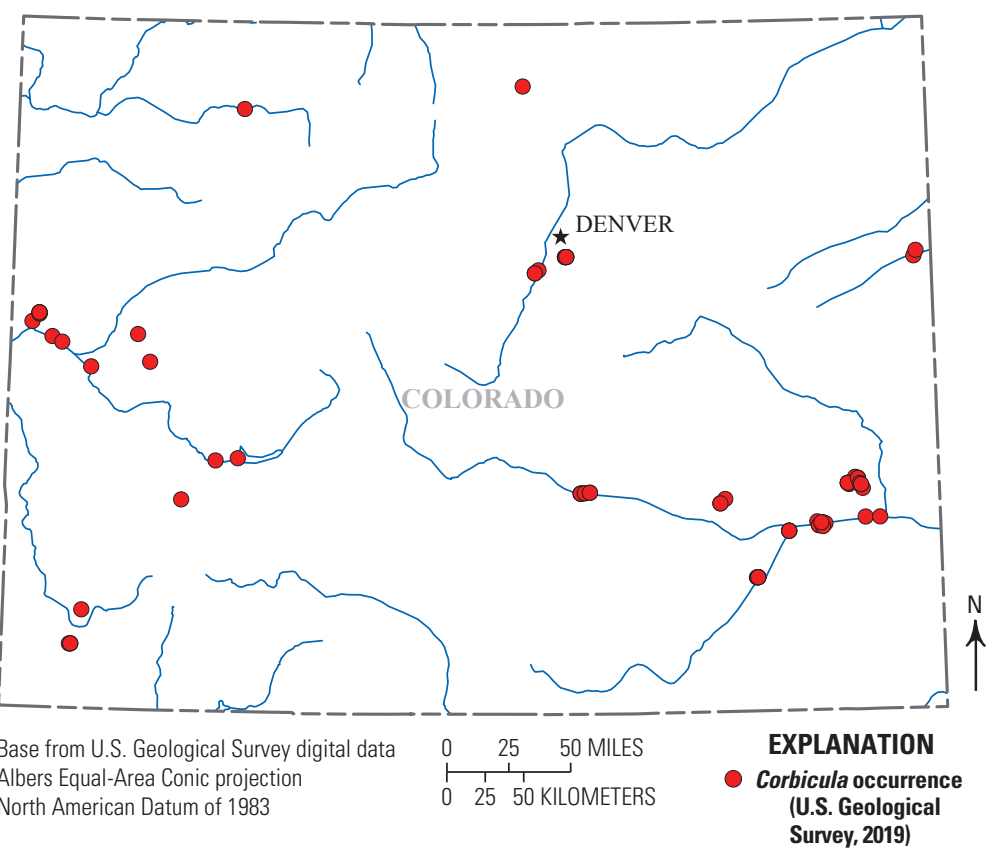

Figure 7. Corbicula spp. occurrences in Colorado through 2019.

\section{Connecticut}

The first reported occurrence of Corbicula in Connecticut was reported in 1990 from the Connecticut River in the thermal effluent plume of a nuclear powerplant near Haddam, where a peak density of more than 23,000 individuals per square meter was reached in 1992 (Morgan and others, 2003). By 2010, dispersal was achieved from Haddam to Hartford, a distance of 24 river kilometers $(\mathrm{km})$. After their 10-year study, Morgan and others (2003) determined that Corbicula survival was dependent on thermal refugia in the winter months from either powerplant thermal effluent or groundwater inflow. They also found that high summer water temperatures played a role in mortality as well. After the closing of the powerplant in 1996, Corbicula was successfully at colonized the river (Morgan and others, 2003). In 2018, the first Corbicula shells outside the Connecticut River drainage were reported from the Housatonic River at New Milford. However, whether an established population exists in the Housatonic River was not reported. On the basis of this review, Corbicula has been found in 5 of 12 HUC8 subbasins and 7 of 8 counties in Connecticut (figs. 3, 5, 6 and 8). 


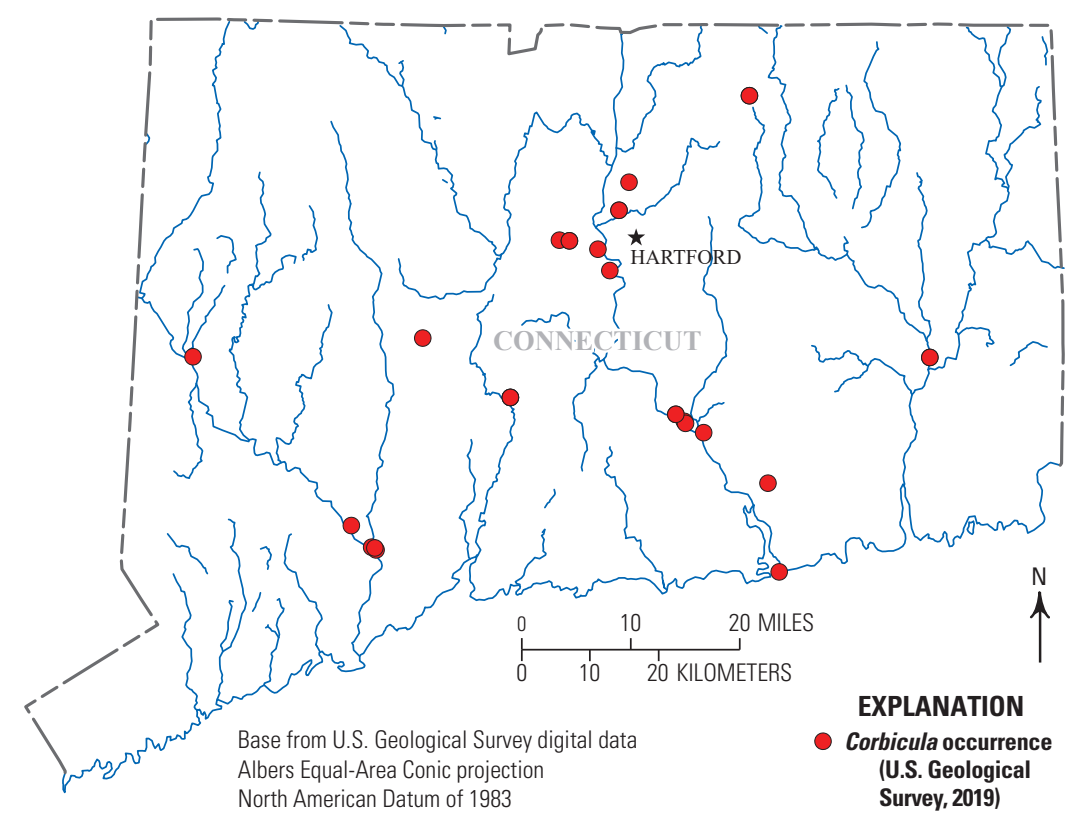

Figure 8. Corbicula spp. occurrences in Connecticut through 2019.

\section{Massachusetts}

Although the exact year was not recorded, the earliest report of Corbicula in Massachusetts occurred prior to 1999 in Stockbridge Bowl, part of the Housatonic River drainage in western Massachusetts (Smith, 1999). A few years after the initial report, a collection was made in 2001 from the Charles River just west of Boston, followed by a collection made in Sampson Pond near Plymouth in 2002. Additional specimens were later collected from the Charles River in 2003 (MCZ 338294). Outside the Boston area, Corbicula was found in the Quinebaug River at East Brimfield Lake in 2006, Rumford (MCZ 380086) and Taunton (MCZ 380030) Rivers in 2010, Nemasket River in 2013, Blackstone River in 2015, and Concord and Sudbury Rivers in 2016. In addition to these rivers, Corbicula occurrences have been reported in 18 small ponds, lakes, and reservoirs across Barnstable, Bristol, Hampden, Middlesex, Norfolk, Plymouth, and Worcester Counties: Bennett Pond, Congamond Lakes, Dudley Pond, Fivemile Pond, Fort Meadow Reservoir, Hamblin Pond, Lake Chaubunagungamaug, Lake Cochituate, Lake Sabbatia (MCZ 359356), Long Pond (MCZ 359334), Mashpee Pond, Massapoag Pond, Middle Pond, Noquochoke Lake (MCZ 353954), Oldham Pond, Spy Pond, Tispaquin Pond, and Winnecunnet Pond (MCZ 359366).
Given the temperate climate of the State, winter water temperatures of many Corbicula collection locations were found to be greater than its lower lethal limit (Colwell and others, 2017). Corbicula is considered a successful invader across the State, as densities in some areas have been reported as high as 6,124 individuals per square meter (Colwell and others, 2017). On the basis of this review, Corbicula has been found in 11 of 20 HUC8 subbasins and 10 of 14 counties in Massachusetts (figs. 3, 5, 6, and 9).

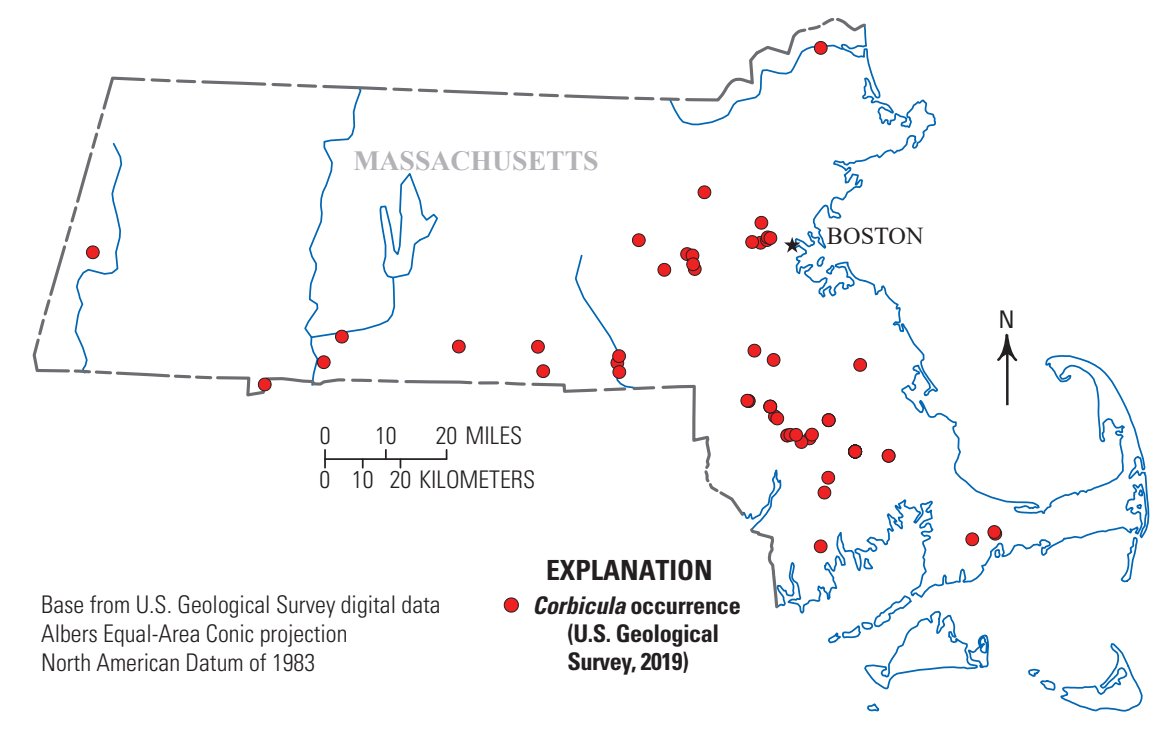

Figure 9. Corbicula spp. occurrences in Massachusetts through 2019. 


\section{Montana}

The first evidence of Corbicula in Montana was reported in June 2019 when several empty shells were found at Lake Elmo near Billings in the Yellowstone-Missouri River drainage (USGS, 2019). In a subsequent survey one month later, several live juvenile specimens were collected, possibly indicating an established population (S. Schmidt, Montana Fish, Wildlife and Parks, written commun., 2019). No other collections have been reported in the State. On the basis of this review, Corbicula has been found in 1 of 115 HUC8 subbasins and 1 of 56 counties in Montana (figs. 3, 5, 6, and 10).

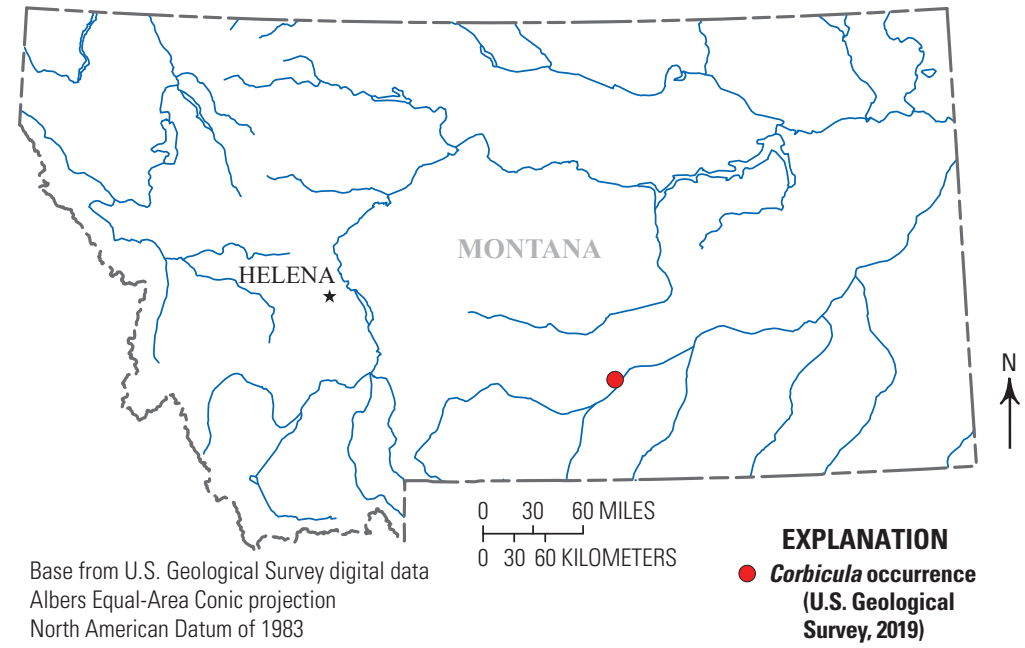

eastern border as far upriver as Yankton, South Dakota (INHS 86729). Collections were made for the first time in the Republican River (INHS 86907-86911) in Nebraska near the Kansas border in 2016. Small waterbodies in Nebraska with Corbicula occurrences were predominantly in the Platte River system and include Antelope Creek (INHS 86738), Beaver Lake (INHS 86741), Birdwood Lake, Bluestem Lake (INHS 86735), Box Elder Creek, Branched Oak Lake (INHS 86904), Bridgeport State Recreation Area lakes (INHS 86903), Cardwell Branch, Conestoga Lake (INHS 86734), East Twin Lake (INHS 86886), Fremont Slough (INHS 86889), Gothenburg Canal (INHS 86744), Holmes Creek, Holmes Lake (INHS 86881), Lake Maloney (INHS 86898), Lake Minatare (INHS 86901), Lowline Canal (INHS 86720), Middle Creek, North Branch Salt Creek, North Oak Creek, Oak Creek (INHS 86883), Olive Creek Lake, Pawnee Lake (INHS 86882), Republican River, Salt Creek, South Channel Platte River (INHS 86740), Sutherland Canal (INHS 86721), Thirtymile Canal (UCM 40930), Tri-County Supply Canal (INHS 86888), Turkey Creek, Wildwood Lake (INHS 86743), Wood River, Yankee Hill Lake (INHS 86895), and Zorinsky Lake (INHS 86730). It is likely that Corbicula is established in the drainages of the Missouri, Platte, and Republican Rivers. On the basis of this review, Corbicula has been found in 14 of 67 HUC8 subbasins and 20 of 93 counties in Nebraska (figs. 3, 5, 6, and 11).

Figure 10. Corbicula spp. occurrences in Montana through 2019.

\section{Nebraska}

The earliest reported collections of Corbicula in Nebraska occurred in 1991 from the Cozad Canal along the Platte River in the south-central part of the State and from Stagecoach Lake located south of Lincoln in the Lower Platte drainage (Freeman and Perkins, 1992). Since the initial collections, Corbicula has dispersed into reservoirs and rivers primarily in the Lincoln and Omaha areas, as well as into many previously uninhabited canals, creeks, and along the Platte River (INHS 86906) from central Nebraska to the border with Wyoming. Beginning in 2000, collections were made in the Missouri River along Nebraska's

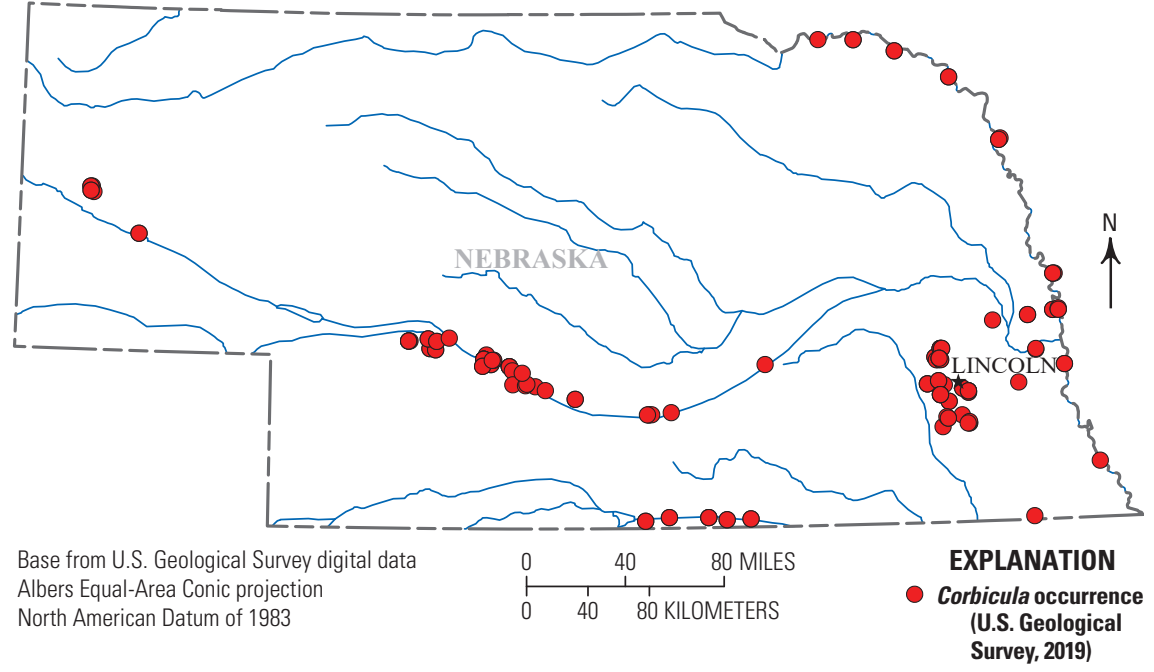

Figure 11. Corbicula spp. occurrences in Nebraska through 2019. 


\section{New Hampshire}

The first report of Corbicula in New Hampshire was a collection from the Merrimack River near Manchester in 2007 (Smagula and others, 2018). Upriver of Manchester near the town of Hooksett, specimens were collected just downstream from a power station in Bow in 2011 (Normandeau Associates, Inc., 2012). Additional locations were discovered in 2012 and 2013 at Cobbetts Pond in Windham, followed by Long Pond near Nashua and Wash Pond near East Hampstead. In 2017, collections were made in Beaver Lake, Canobie Lake, Great Pond, and Little Island Pond (Richardson and Selby, 2020). Corbicula has only been reported from the Merrimack River drainage in southeastern New Hampshire. Reproduction was indicated by the presence of several age classes and "abundant" densities as high as 1,286 individuals per square meter (Smagula and others, 2018). Although Corbicula was not expected to survive in the cold winter temperatures of the State, it is considered established in 12 of 13 locations without the presence of industrial thermal effluent refugia provided by powerplants (Richardson and Selby, 2020). On the basis of this review, Corbicula has been found in 1 of 17 HUC8 subbasins and 3 of 10 counties in New Hampshire (figs. 3, 5, 6, and 12).

\section{Puerto Rico}

Corbicula was first reported in Puerto Rico in 1998 from a river near the town of Cayey and 2 years later from Lago de Cidra (Río Bayamón) and Lago La Plata (Río de la Plata) reservoirs (Williams and others, 2001). Since then, Corbicula has been collected from Río Turabo, Lago de Guajataco (Río Guajataco), Lago Loiza (Río Grande De Loiza), Lago Patillas

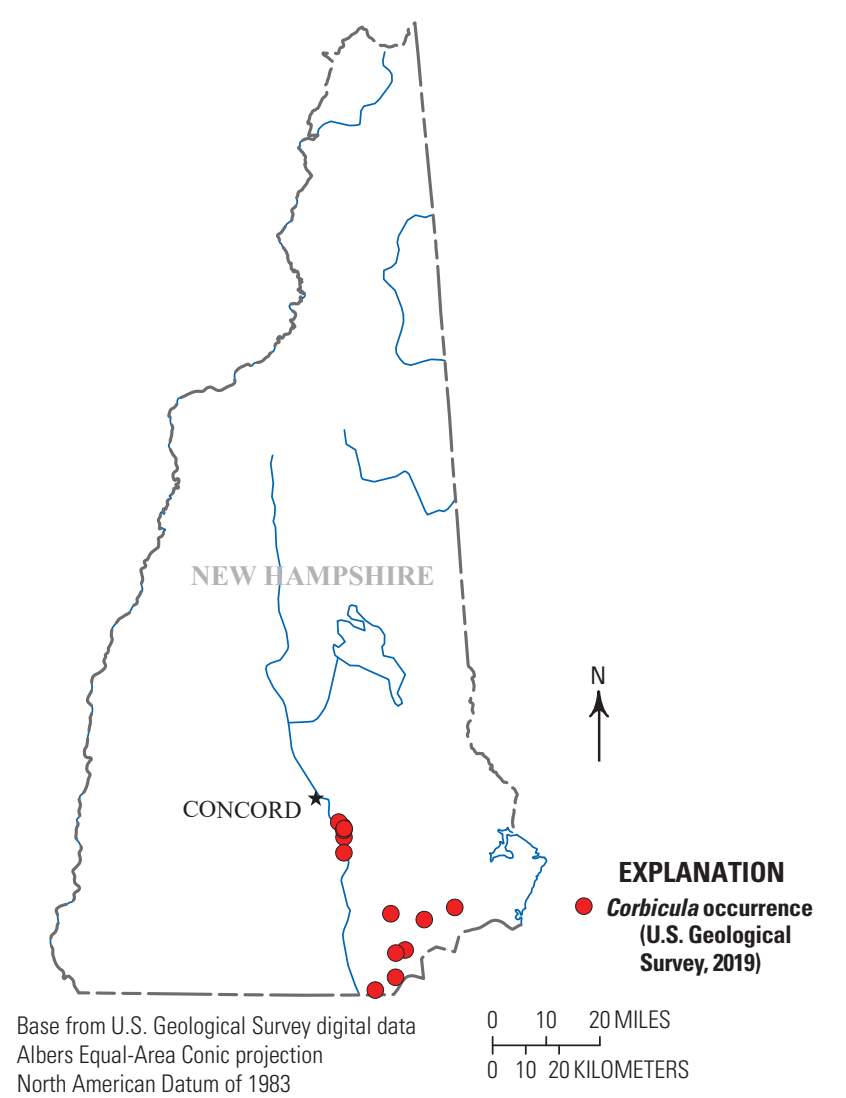

Figure 12. Corbicula spp. occurrences in New Hampshire through 2019.

(Río Grande de Patillas), and Presada Loco (Río Loco). Although the number of reported collection locations is small, Corbicula is established and spatially widespread across the island Territory. On the basis of this review, Corbicula has been found in 3 of 5 HUC8 subbasins and 9 of 78 municipalities in Puerto Rico (figs. 3, 5, 6, and 13).

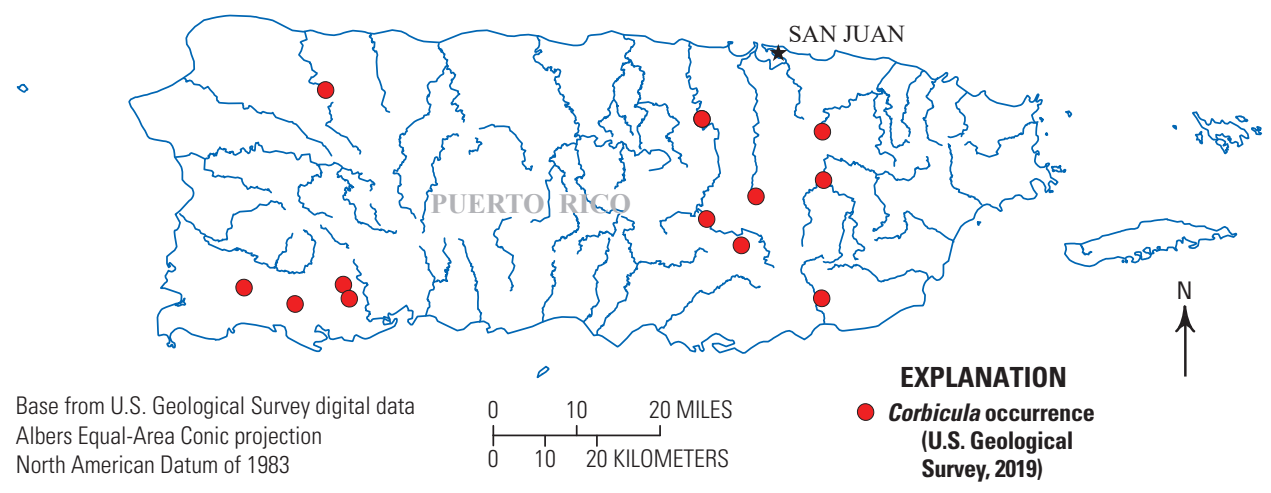

Figure 13. Corbicula spp. occurrences in Puerto Rico through 2019. 


\section{Rhode Island}

The first collection of Corbicula in Rhode Island occurred in 1999 from Tiogue Lake near the town of Coventry in the Narragansett drainage (USGS, 2019). In 2005, Corbicula was reported from the Pawtuxet River, the outlet for Tiogue Lake. Collections were again made in Tiogue Lake in 2009 (MCZ 380326) and 2014. From 2007 to 2014, Corbicula expanded its distribution, as collections were made in 12 additional waterbodies: Gorton Pond (MCZ 380315), Happy Hollow Pond, James V. Turner Reservoir, Lake Mishnock, Peace Dale Reservoir, Pocasset Pond, South Branch Pawtuxet River, Stafford Pond, Upper Dam Pond, Warwick Pond, Wenscott Reservoir, and Worden Pond. Although the number of Corbicula occurrences reported in Rhode Island is low, its distribution includes 14 waterbodies spanning much of the State; we therefore assume it is established. On the basis of this review, Corbicula has been found in 3 of 5 HUC 8 subbasins and 4 of 5 counties in Rhode Island (figs. 3, 5, 6, and 14).
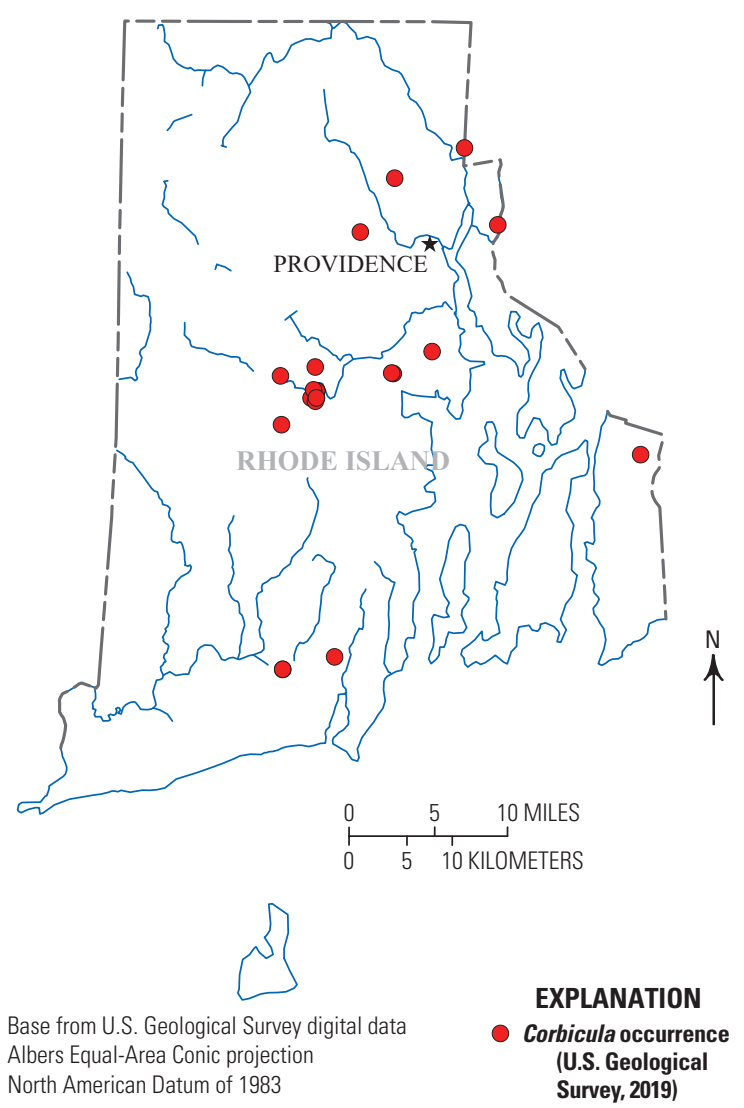

Figure 14. Corbicula spp. occurrences in Rhode Island through 2019.

\section{South Dakota}

The first record of a Corbicula collection in South Dakota was in 2004 from the Missouri River, just below Gavins Point Dam near Yankton, where the river forms the border with Nebraska (USGS, 2019). Since then, a limited number of collections have been made in the river above Gavins Point Dam in Lewis and Clark Lake and upstream to above Fort Randall Dam in Lake Francis Case near the town of Academy. In the western part of South Dakota near the border with Wyoming, an established population was discovered in Angostura Reservoir on the Cheyenne River in 2014. On the basis of this review, Corbicula has been found in 3 of 53 HUC8 subbasins and 6 of 66 counties in South Dakota (figs. 3, 5, 6, and 15).

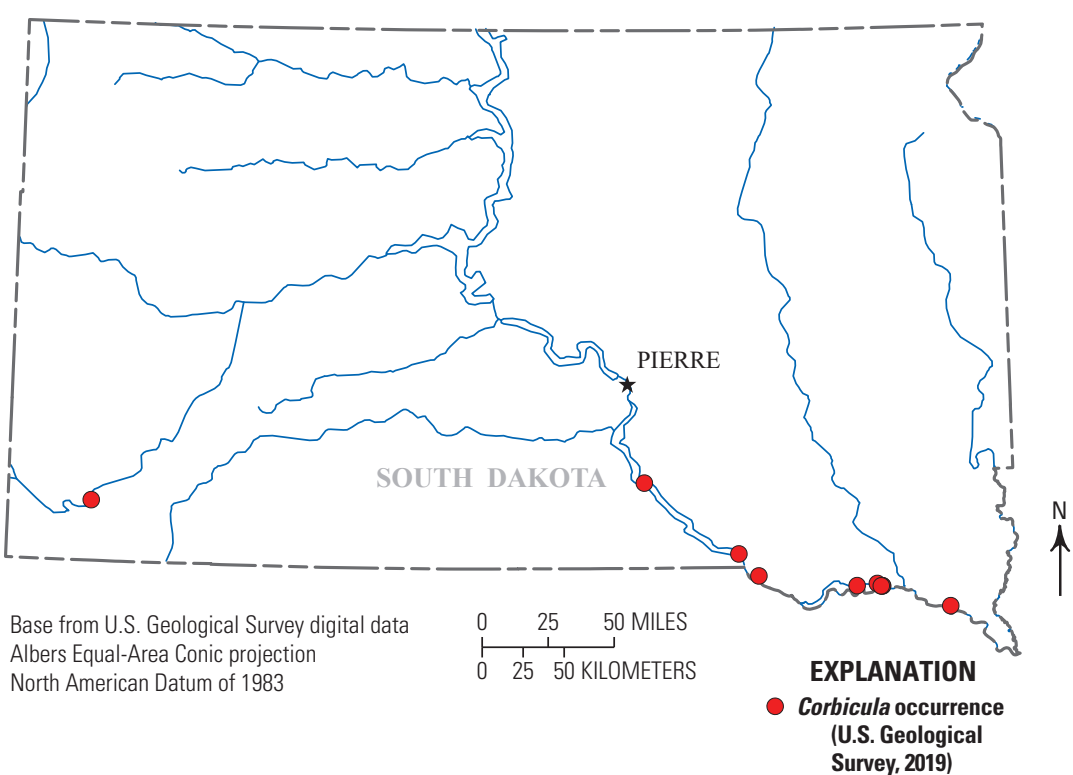

Figure 15. Corbicula spp. occurrences in South Dakota through 2019. 


\section{Vermont}

Corbicula was first discovered in Vermont when an established population was found in Lake Bomoseen in 2016 (USGS, 2019). The lake is located along the State's western border in the Mettawee River drainage and only $26 \mathrm{~km}$ east of Lake George in the State of New York, where a large established population has existed since 2011. No other observation or collection locations have been reported in Vermont. On the basis of this review, Corbicula has been found in 1 of 18 HUC8 subbasins and 1 of 14 counties in Vermont (figs. 3, 5,6 , and 16).

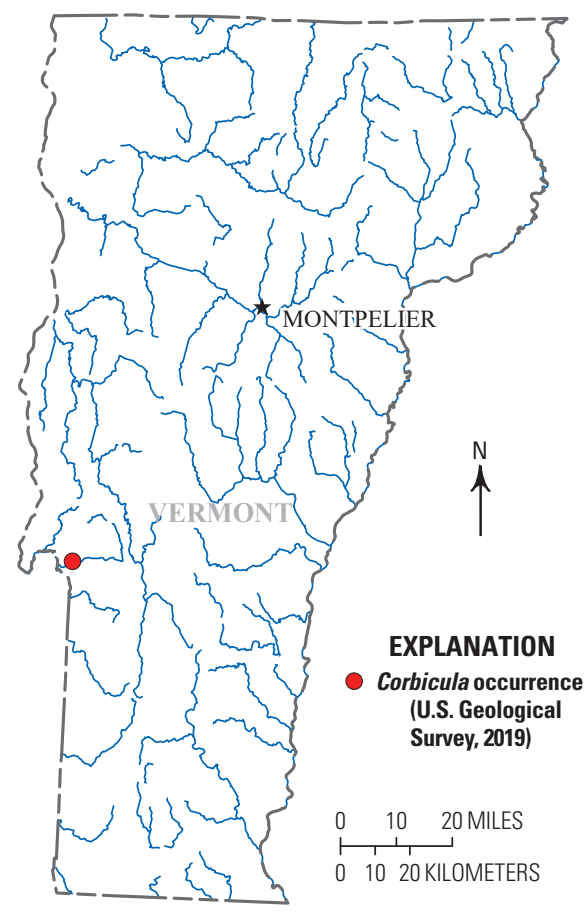

Base from U.S. Geological Survey digital data Albers Equal-Area Conic projection North American Datum of 1983

Figure 16. Corbicula spp. occurrences in Vermont through 2019.

\section{Wyoming}

The first reported collection of Corbicula in Wyoming was in 2011 from the Laramie River at Fort Laramie National Historic Site in the southeastern part of the State (USGS, 2019). This collection was followed by additional collections in 2011 and 2013 that spanned nearly the length of the Laramie River within the State. In 2014, Corbicula was collected from the Fort Laramie Canal, which receives farm irrigation water diverted from the North Platte River. The earliest collection in the North Platte River was made near Guernsey in 2015 and from Horse Creek in 2018 also within the North Platte River drainage. The only reported collections outside the North Platte and Laramie Rivers occurred in 2017 from the Belle Fourche River at Keyhole Reservoir in northeast Wyoming. On the basis of this review, Corbicula has been found in 6 of 80 HUC 8 subbasins and 4 of 23 counties in Wyoming (figs. 3, 5, 6, and 17).

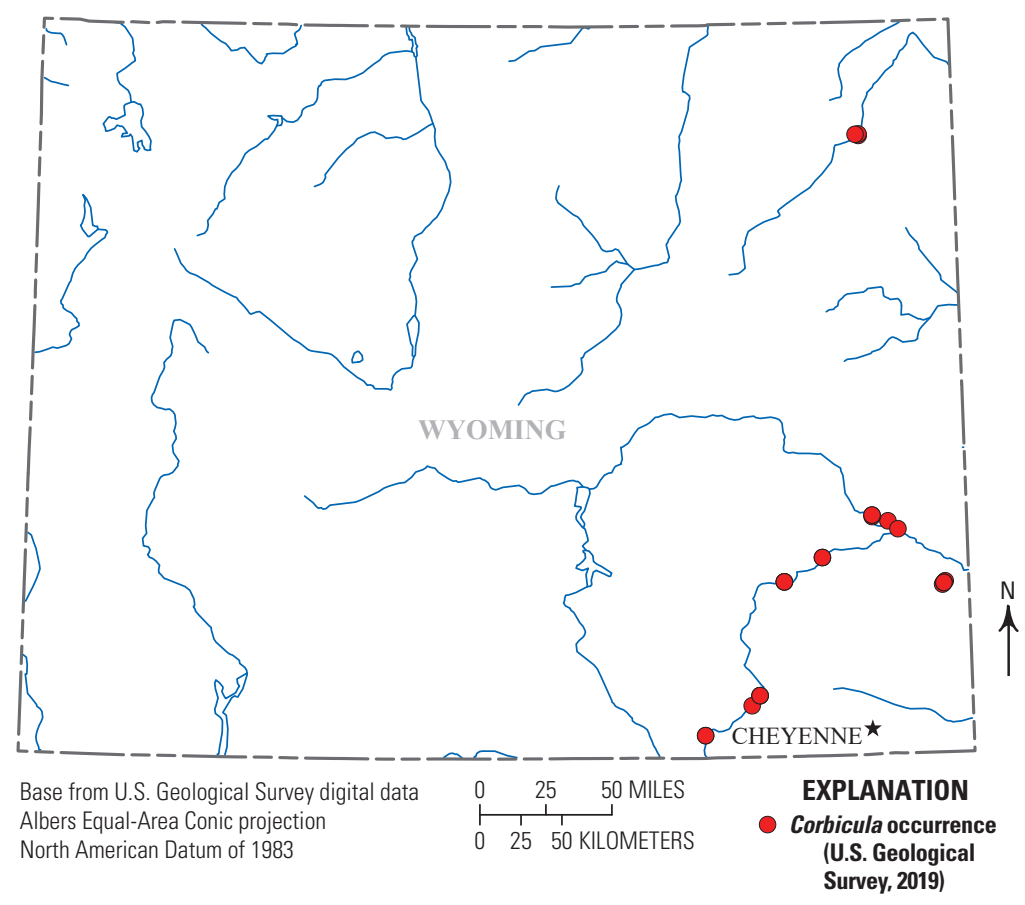

Figure 17. Corbicula spp. occurrences in Wyoming through 2019. 
Corbicula Occurrences in Additional Waterbodies of States and Districts Where It Was Present Prior to 1985

Accessible distribution information compiled for Corbicula through 1984 reported its occurrence in 37 States (Counts, 1991). Since 1984, all 37 States have undergone increases in Corbicula distribution. States with the most additional waterbodies where Corbicula was present prior to 1985 include Georgia, Illinois, Indiana, Kansas, New York, North Carolina, South Carolina, Tennessee, and Virginia. We recognize that there may be sampling and reporting biases occurring within these States with some having more active survey programs and research activities than others. States such as Iowa and Pennsylvania with few reported occurrences prior to 1985 have recognized that Corbicula is present throughout many of their State's waters even though many post-1984 occurrences have not been formally documented. Below are accounts for each State and District of Columbia listing Corbicula occurrences in waterbodies for the first time after 1984 (that is, occurrences reported after Counts, 1991) and reported occurrences in additional waterbodies prior to 1985 but not included in Counts (1991).

\section{Alabama}

The earliest reported location of Corbicula in Alabama was in 1960 from the Tennessee River at Wheeler Reservoir (Sinclair and Isom, 1961). By the mid-1970s it was reported as widespread across the State and in all major drainages. In addition to the Tennessee River, Counts (1991) listed Corbicula in 14 other rivers through 1984: Alabama, Black Warrior, Cahaba, Choctawhatchee, Conecuh, Coosa, Flint, Mobile, Paint Rock, Pea, Sepulga, Sucarnoochee, Tallapoosa, and Tombigbee. Corbicula had also been found in the following 23 creeks: Big Cedar, Big Nance, Buck, Burnt Corn, Cedar, Cypress, Indian, Limestone, Little Cypress, Little Uchee, Locust Fork, Mud, Murder, Okatuppa, Peckerwood, Santa Bogue, Second, Sougahatchee, Sugar, Terrapin, Town, Tubbs, and Uchee (Counts, 1991). Collection locations not included in Counts (1991) were the Estill Fork (INHS 14456) in 1983 and Gantt Lake (INHS 26303) in 1968.

After 1984, Corbicula was found for the first time in 5 additional rivers and 117 creeks. The rivers are Brier Fork Flint (OSUM 75764), Buttahatchee (CMNH 94777), Chattahoochee (OSUM 56991), Sipsey (NCSM 31991), and
Yellow (UF 126844). Creeks include Abbie, Alamuchee (OSUM 57690), Amos Mill (UF 373725), Autrey (NCSM 32803), Baker, Bashi, Battle, Bear (OSUM 59141), Big (NCSM 32710), Big Black (NCSM 43168), Big Flat (UF 365262), Big Prairie, Big Swamp (UF 197726), Blackwater (UF 79099), Blanket (MMNS 13187), Bogue Chitto (NCSM 32013), Bogueloosa, Boone (OSUM 5811), Bottle (NCSM 32018), Brockway (OSUM 66925), Brushy (NCSM 32725), Buck (NCSM 46766), Bullbarn (OSUM 58806), Callaway (NCSM 55692), Capsey (OSUM 31030), Catoma, Cheaha, Chewacla (INHS 10406), Chilatchee (MMNS 13171), Chulafinnee (UF 313391), Claybank (MMNS 13309), Clear (UF 197742), Coal Fire (OSUM 66255), Copperas (NCSM 43244), Cottingham (NCSM 43068), Cowarts (NCSM 32709), Cripple (OSUM 31142), Crow (NCSM 55816), Double Bridges, Dry (MMNS 13316), Five Runs (NCSM 31984), Flannagin, Flat (UF 381432), Fourmile (NCSM 43248), Gurley (MMNS 11415), Halawakee, Hatchechubbee, Hawkins (NCSM 32029), Hester (OSUM 57557), Hill (NCSM 43265), Hillabee (INHS (24552), Hogan, Horse (NCSM 32647), Howards Mill, Hunter, Irwin Mill (NCSM 32795), Jones (NCSM 55781), Jordan (USNM 874829), Kinterbish (OSUM 66926), Lightwood Knot (NCSM 32038), Limestone (NCSM 32726), Little, Little Bassett (MMNS 11422), Little Cedar, Little Paint (OSUM 58037), Little Prairie, Little Shades (NCSM 43213), Little Wolf (UF 365428), Lost (OSUM 58913), Lubbub (UF 197615), Luxapallila (NCSM 40831), Manoy (UF 264517), McCalls (UF 365361), Middle Black (NCSM 43169), Middle Fork Cowikee, Mulberry, North Fork Cowikee, Oakmulgee (OSUM 57662), Okatuppa, Opintlocco (INHS 24549), Osanippa, Otter (NCSM 32801), Pace (MMNS 13318), Panther (NCSM 32039), Patsaliga (NCSM 31993), Peel (NCSM 43226), Persimmon, Pigeon (UF 224279), Pinchgut (NCSM 44180), Pine Barren, Piney Woods (NCSM 43234), Prairie (MMNS 13497), Pursley (UF 126843), Ragsdale (OSUM 69608), Randons, Rice (OSUM 56996), Robinson (NCSM 32071), Salitpa, Sandy, Schultz (NCSM 43272), Shambley (LACM 1991-50.2), Shoal (MMNS 7359), Simmons (UF 370650), Sixmile (MMNS 11413), South Fork Cowikee, Spivey Mill, Spring (NCSM 43252), Stallings (NCSM 31986), Sturdevant (UF 365430), Three Run (NCSM 32011), Tuckabum, Turkey, Ulcanush, Uphapee (INHS 3348), White Oak, Widows (NCSM 55722), and Youngblood (UF $313348)$. On the basis of this review, Corbicula has been found in 42 of 53 HUC8 subbasins and 66 of 67 counties in Alabama (figs. 3, 5, 6, and 18). 


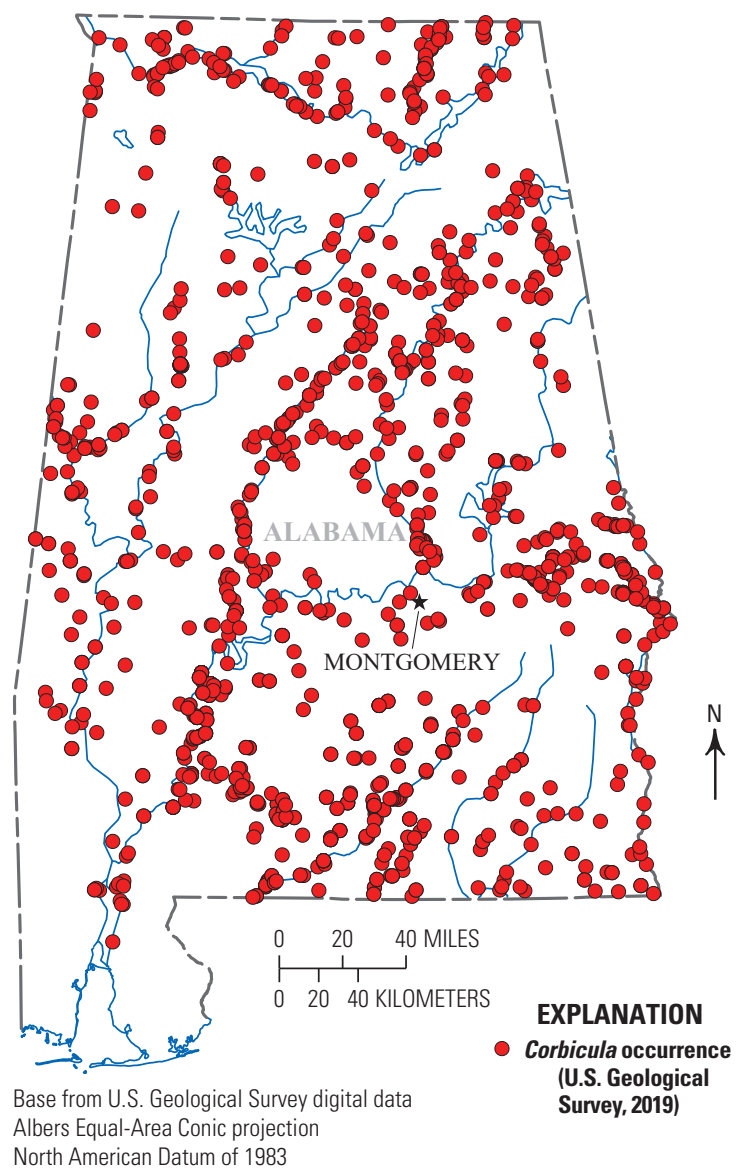

Figure 18. Corbicula spp. occurrences in Alabama through 2019.

\section{Arizona}

Corbicula was first reported in Arizona in 1955 from the Colorado River at Yuma on the California border (see Counts, 1991). The following year it was observed a distance of approximately $250 \mathrm{~km}$ away in the interior of the State in dredged spoils along a canal behind a Phoenix botanical park (Dundee and Dundee, 1958). The authors believed that Corbicula arrived in the interior of the State from the Colorado River by the early 1950s, where it dispersed by using the system of irrigation canals. During the next three decades, Corbicula further dispersed in the Colorado River and was also found in the Agua Fria, Gila, Salt (including Apache, Canyon, Theodore Roosevelt, and Saguaro Lakes [Rinne, 1974]), and Verde Rivers along with the Arizona, Consolidated, Eastern, Main, and Southern Canals (see Counts, 1991). Although Corbicula may have been in Lake Mead (Colorado River) as early as the 1950s in the Nevada portion of the lake (Ingram, 1959), the earliest record in the Arizona portion of the lake may have been from the early 1960s (Bequaert and Miller, 1973). Not included in Counts (1991) was a 1984 collection made in Oak Creek near Sedona (UWBM 39469).

After 1984, one of the most notable range expansions in the West was the discovery of Corbicula in Lake Powell, a large reservoir on the Colorado River upriver from the Grand Canyon and Glen Canyon Dam. With the dam and a small portion of the reservoir within Arizona, the earliest collection reported for Lake Powell was made in the Wahweap Creek arm in 1990 (ANSP 447797). However, with Corbicula present downstream in Lake Mead in neighboring Nevada by the 1950s, it seems likely that it would have arrived in Lake Powell significantly earlier than 1990 . We found only one additional waterbody where a first-time collection was made after 1984, the Virgin River in northwestern Arizona in 2004. On the basis of this review, Corbicula has been found in 16 of 84 HUC8 subbasins and 7 of 15 counties in Arizona (figs. 3, 5, 6 , and 19).

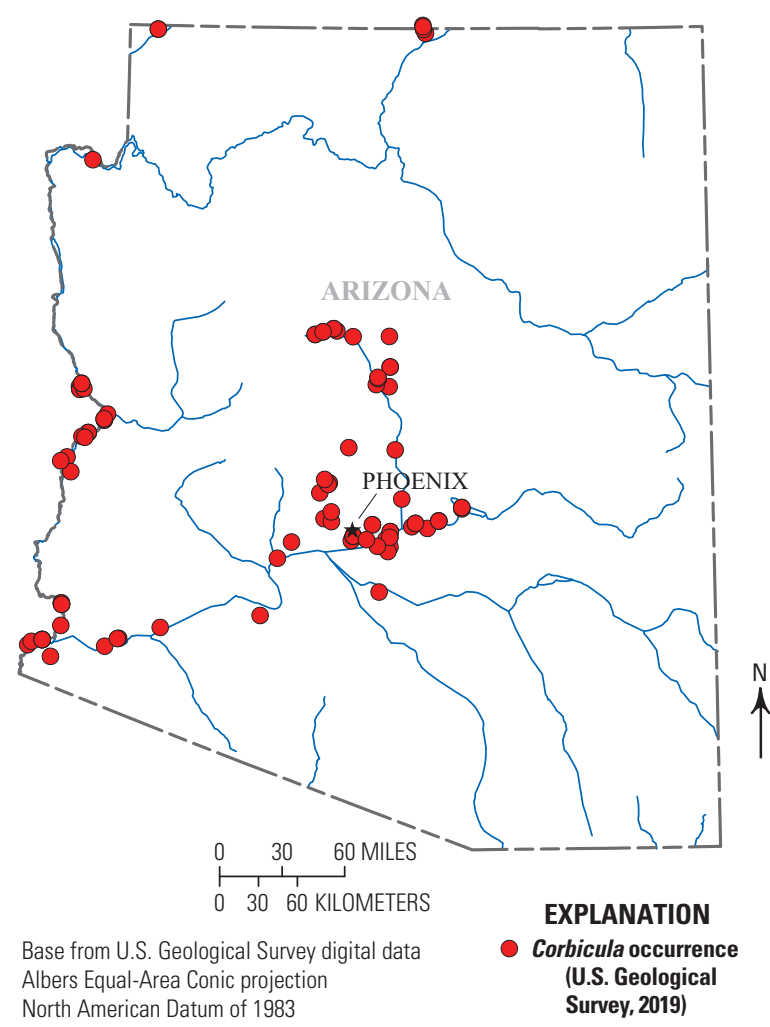

Figure 19. Corbicula spp. occurrences in Arizona through 2019. 


\section{Arkansas}

The earliest known collection of Corbicula in Arkansas was made in 1964 from the White River (OSUM 13992) (see Counts, 1991), followed later in the year from the Black and St. Francis Rivers. Over the next 20 years, Corbicula dispersed widely across much of the State into all of the major river drainages. In addition to the White River, Counts (1991) listed 20 other waterbodies with Corbicula occurrences: Arkansas, Bayou Bartholomew, Boeuf, Buffalo, Caddo, Coon Bayou, Frog Bayou, La Grue Bayou, L'Anguille, Little, Little Red, Maniece Bayou, McKinney Bayou, Mississippi, Ouachita, Red, Spring, Strawberry, and Sulphur Rivers and Champagnolle Creek. We found collections made prior to 1985 from 11 additional waterbodies not included in Counts (1991): Cossatot, Current (MMNS 13312), Eleven Point, Maumelle, Mulberry (USAO 2110), Petit Jean (OSUM 54403), Saline (OSUM 84350), South Fork Spring, and Tyronza (NCSM 55668) Rivers, as well as Cooper (OSUM 54460) and Curia (OSUM 47800) Creeks.

After 1984, Corbicula was found for the first time in the following 18 rivers: Alum Fork Saline, Antoine, Essex Bayou, Illinois, Indian Bayou, Jacks Bayou, Kings (INHS 12648), Left Hand Chute Little, Little Bayou Meto, Little Missouri, Middle Fork Saline, Petit Jean, Poteau, Right Hand Chute Little, South Fork Little Red, South Fork Spring, South Fourche LaFave, and St. Francis. After 1984, Corbicula was found for the first time in the following 18 creeks: Brushy, Caney, Dutch, East Fork Cadron, Fourche, Gin, Honey Cypress Ditch, Hudson, James (INHS 14166), Leatherwood,

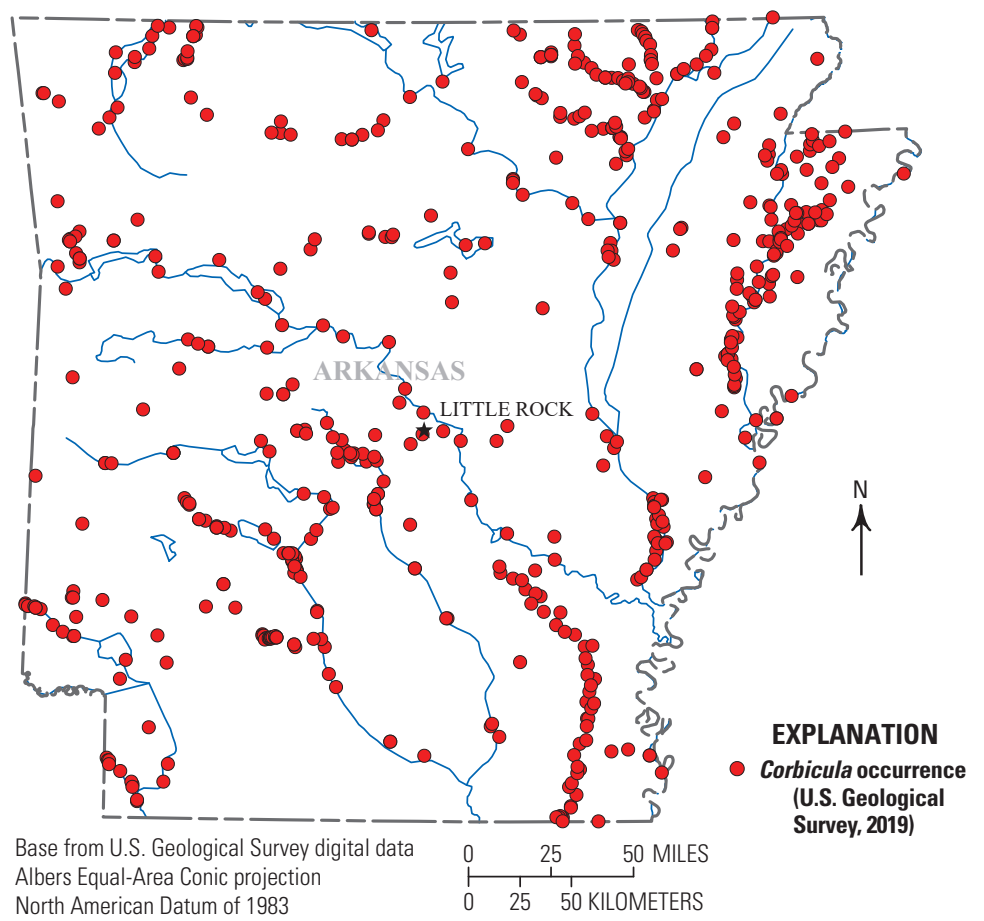

Figure 20. Corbicula spp. occurrences in Arkansas through 2019.
Lee, Little Vache Grasse, Middle Fork Illinois Bayou, Middle Fork Saline, North Fork Cadron, South Big, Sullivan (NCSM 28685), and Williams. It was also found for the first time in the following 17 lakes: Ashbaugh, Big Horseshoe, Buck, Bull Shoals, Burnt, Charles, Escronges, Frierson, Greeson, Hogue, Little Moon, Mallard, Monticello, Norfolk, Poinsett, Prairie, and Swan. On the basis of this review, Corbicula has been found in 48 of 58 HUC8 subbasins and 71 of 75 counties in Arkansas (figs. 3, 5, 6, and 20).

\section{California}

The earliest record of Corbicula in California was a collection made in 1945 from the Sacramento River east of San Francisco, where it quickly became a nuisance by interfering with the operation of water pumping plants (Hanna, 1966). By the early 1950s, Corbicula was found clogging $800 \mathrm{~km}$ of irrigation canals throughout the Imperial Valley of southern California (Fitch, 1953). Corbicula in southern California's water supply is believed to have originated from the unintentional introduction of larvae into Colorado River reservoirs via bait buckets of fishermen from the San Joaquin River near Sacramento (Fitch, 1953). From the 1950s to the mid-1980s, Corbicula continued to be reported from a variety of waterbodies spanning the central and southwestern regions of the State, including the following 16 rivers: Colorado, Feather, Kern, Merced, Middle, Mokelumne, Old, Owens, Russian, Sacramento, Salinas, San Joaquin, Santa Margarita, South Fork Mokelumne, Stanislaus, and Tuolumne (see Counts, 1991). Additional waterbodies with Corbicula occurrences by 1984 included 18 lakes and reservoirs (including the Salton Sea), 13 canals and aqueducts, and only one creek, Little Tujunga (see Counts, 1991). We found one collection from an additional waterbody, Yosemite Lake in Merced in 1956 (DMNH 122003), not included in Counts (1991).

After 1984, collections continued to be made widely in the State. An additional 10 rivers with occurrences for the first time were American, Cosumnes (INHS 19805), Klamath, Nacimiento (INHS 14113), North Fork Feather, North Yuba, Pajaro (OSUM 28959), Pit, San Antonio (INHS 15520), and Sweetwater. Creeks with first-time occurrences after 1984 include Aliso (LACM 1996-3.1), Arroyo Grande, Black Mountain, Conejo, Cottage, Malibu (LACM 178559), Muddy, North Fork Willow, Putah, San Francisquito, Sandia, and Troy Canyon. Twenty-one lakes and reservoirs with first-time occurrences after 1984 are Blue (LACM 1987-140.3), Clear (INHS 21305), Donner, Evans (DMNH 91809), Hennessey (OSUM 67059), Hodges (NCSM 35167), Kirkwood, Lost (LACM 2015-12.1), Mosquito, Perris (CR 4741), Rollins, Santa Fe Dam (LACM 2006-30.1), Tulare, Westlake (CMNH 47577), and Wildwood Lakes, as well as Bouquet, Camp Far West, Millerton, New Bullards Bar, Nicasio (NCSM 55733), and Upper 
Crystal Springs (UMMZ 300015) Reservoirs. Corbicula was not reported on the California side of Lake Tahoe until 2008 even though they had been found on the Nevada side since 2002 (S. Hackley, University of California - Davis, written commun., 2008). Canals with first-time Corbicula occurrences after 1984 are Tulare Lake Canal (LACM 1987-150.4) and West Canal located adjacent to Clifton Court Forebay (California Department of Fish and Wildlife, 2009). On the basis of this review, Corbicula has been found in 65 of 136 HUC8 subbasins and 48 of 58 counties in California (figs. 3, 5,6 , and 21).

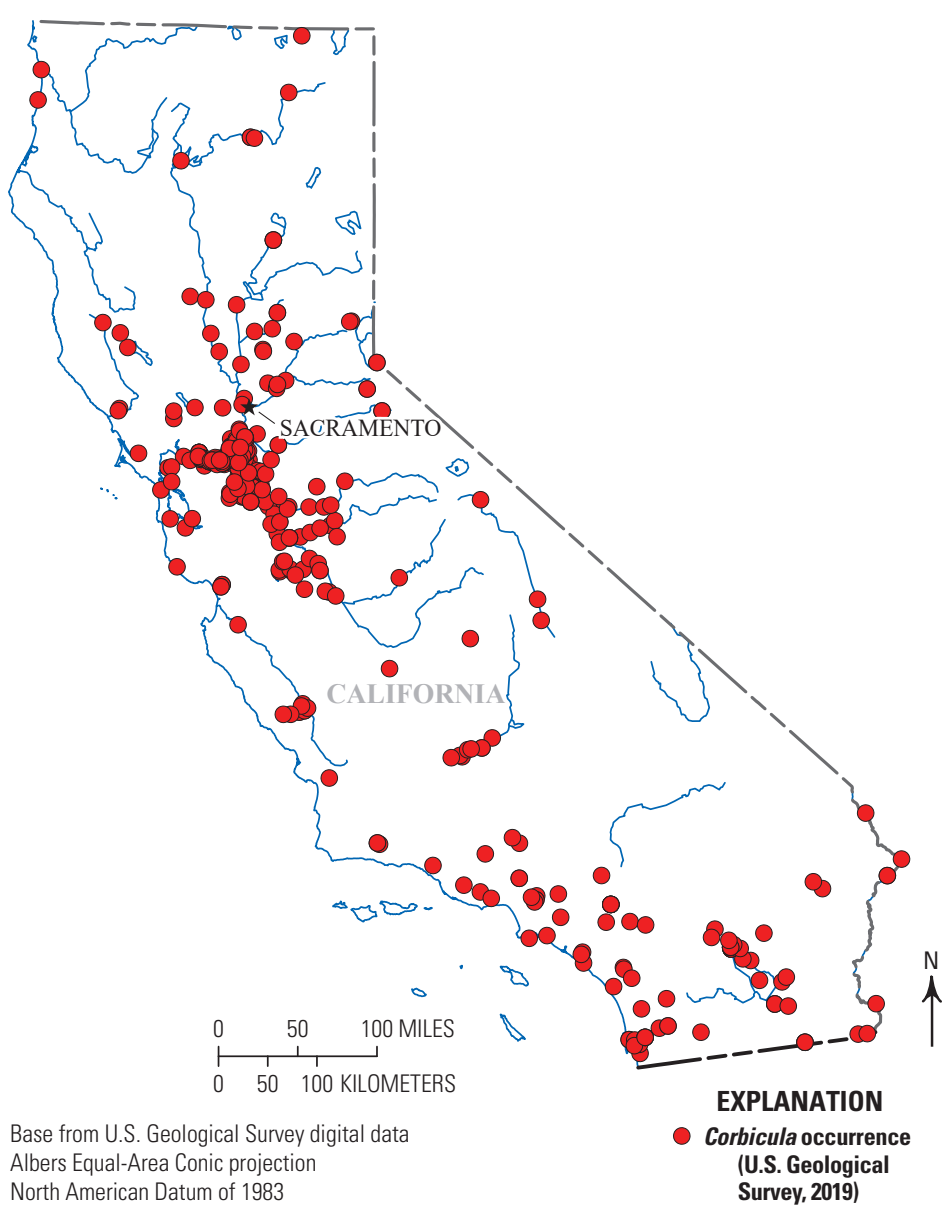

Figure 21. Corbicula spp. occurrences in California through 2019.

\section{Delaware}

Counts (1991) listed the first Corbicula collection in Delaware in 1981 from the Delaware River, New Castle County (TCU 5835). Later in the same year, a collection was made in Butler Mill Branch (USNM 836237), a tributary of the Nanticoke River. Two additional collections mentioned in Counts (1991) included the Nanticoke River in 1982 and an unnamed tributary of the Nanticoke River in 1983. After 1984, Corbicula was collected from the Appoquinimink (ANSP
376367), Christina, and St. Jones (ANSP 376368) Rivers and from Brandywine (DMNH 207009), Cedar (DMNH 221693), Hitch Pond (Branch), Marshyhope (ANSP 376369), and White Clay (DMNH 241001) Creeks. After 1984, collections were made for the first time from the following additional ponds and reservoirs: Lums Pond near Glasgow (DMNH 208128), Records Pond in Laurel (ANSP 376372), Williams Pond in Seaford (NCSM 84389), and Hoopes Reservoir near Wilmington (DMNH 242457). Although the number of waterbodies that have been reported with Corbicula occurrences is relatively small, the locations together span the entire length of the State, from Brandywine Creek in the north to Nanticoke River in the south, possibly indicating a more widespread distribution. On the basis of this review, Corbicula has been found in 4 of 11 HUC8 subbasins and 3 of 3 counties in Delaware (figs. 3, 5, 6, and 22).

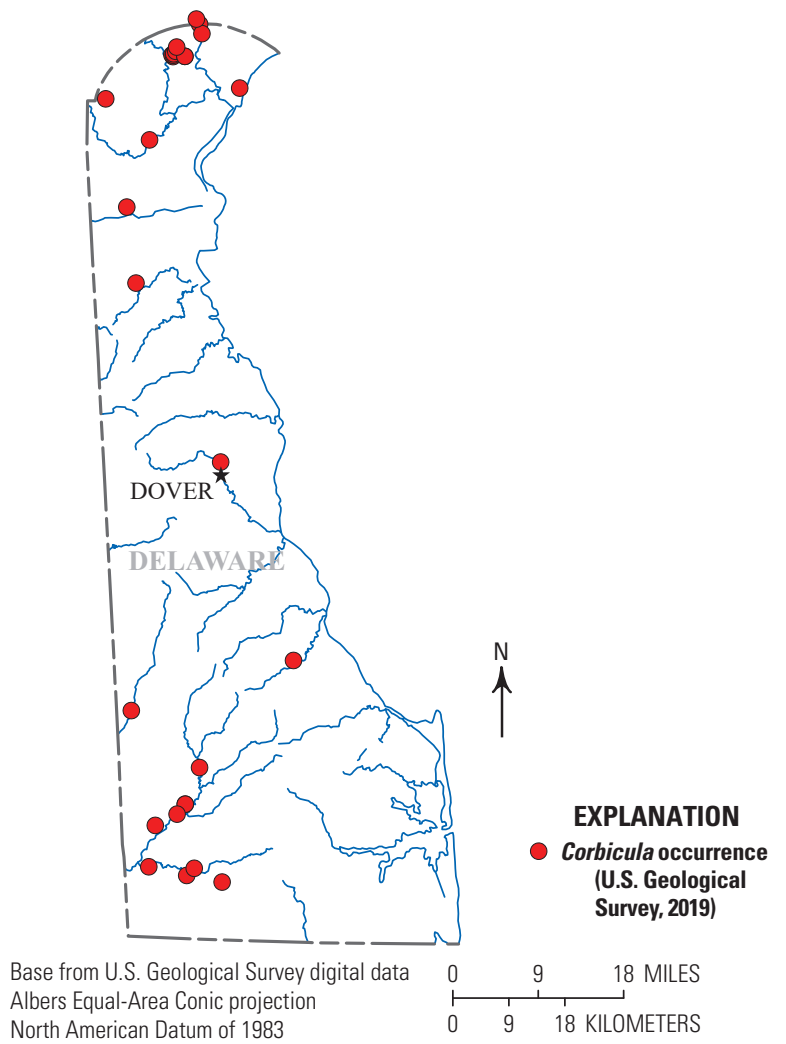

Figure 22. Corbicula spp. occurrences in Delaware through 2019.

\section{District of Columbia}

The earliest reported Corbicula collections in the District of Columbia, and shared with the State of Maryland, were made in the Potomac River in 1978 (Dresler and Cory, 1980). Since then, we found only one collection from an additional waterbody, the Chesapeake and Ohio Canal near Georgetown, 
made in 2009 (CMNH 143992). On the basis of this review, Corbicula has been found in 1 of 2 HUC8 subbasins in the District of Columbia (figs. 3, 5, 6, and 23).

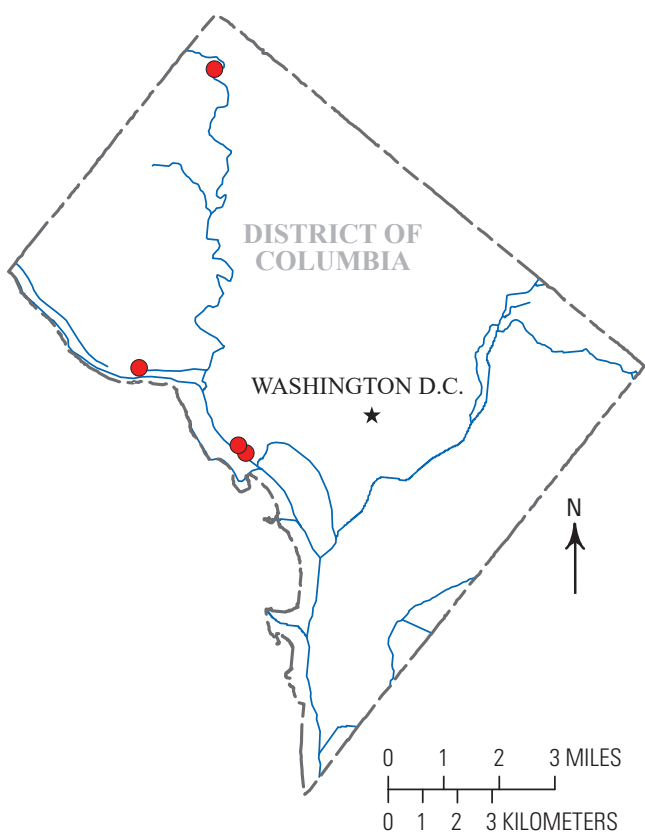

EXPLANATION

Base from U.S. Geological Survey digital data Albers Equal-Area Conic projection

North American Datum of 1983

\section{- Corbicula occurrenc (U.S. Geological Survey, 2019)}

Figure 23. Corbicula spp. occurrences in the District of Columbia through 2019.

\section{Florida}

The earliest report of Corbicula in Florida was in 1960 from the Escambia River north of Pensacola in the western panhandle region of the State (Schneider, 1967). A year later it was reported more than $200 \mathrm{~km}$ to the east in the Apalachicola River. By 1968, Corbicula was found as far south as Lake Okeechobee in the southern peninsula (NCSM 55790). Seventeen additional rivers with reported Corbicula occurrences by 1984 are the Aucilla, Caloosahatchee, Chipola, Choctawhatchee, Ichetucknee, Kissimmee, Myakka, New, Ochlockonee, Ocklawaha, St. Johns, Santa Fe, Steinhatchee, Suwannee, Wekiva, Withlacoochee, and Yellow (see Counts, 1991). Smaller waterbodies include Holmes, Mosquito, North Mosquito, Rocky, and Spring Creeks, as well as a number of canals in the southern part of the peninsula (see Counts, 1991). We found collections made prior to 1985 from six additional waterbodies not included in Counts (1991): Fox Lake (DMNH 181898), Lake Silver (DMNH 123955), Lake Washington (DMNH 18025), Middle Hamilton Lake (DMNH 120597), Silver Springs (DMNH 181867), and Zolfo Springs (DMNH 202188).
After 1984, Corbicula was collected for the first time from 19 additional rivers in Florida: Alafia, Alapaha, Brothers, Conecuh, Eau Gallie, Econfina, Florida, Hillsborough, Little, Manatee, Peace, St. Marys, Sampson, Shoal, Silver, Styx, Waccasassa, Wacissa, and Wakulla. There were also 41 additional creeks with first-time occurrences and include Alligator, Arbuckle (NCSM 28343), Attapulgus, Baker (UF 214600), Bayou Marcus (MMNS 13156), Bearman, Beaverdam, Big Escambia (UF 336371), Black, Blackwater (UF 313381), Clark, Cow, Cross, Deep (UF 92835), Deer Prairie, Dry, East Branch Troublesome (NCSM 55821), East Pittman (NCSM 32055), Econfina (UF 224189), Equaloxic, Fisheating (UF 477533), Flint (NCSM 40682), Gator (UF 359876), Harrison, Hoffman, Hogtown, Irwin Mill, Juniper, Little Brothers Slough, Morgan Hole (NCSM 28361), Orange (INHS 9792), Payne (UF 181514), Sandy (UF 290565), Shell, Saul, Spanish (INHS 32384), Swift (UF 340425), Waddells Mill (UF 197711), West, White (UF 224257), and Wrights (NCSM 31977). In 2014, specimens identified as C. largillierti were collected from a retention pond in Palm City, Martin County (INHS 78810). Corbicula and native aquatic mollusks are absent in several Florida drainage systems such as the Blackwater River, as well as tributaries originating in the Okefenokee Swamp in southern Georgia, because of the low $\mathrm{pH}$ and nutrient levels (Williams and others, 2014). On the basis of this review, Corbicula has been found in 44 of 56 HUC8 subbasins and 65 of 67 counties in Florida (figs. 3, 5, 6, and 24).

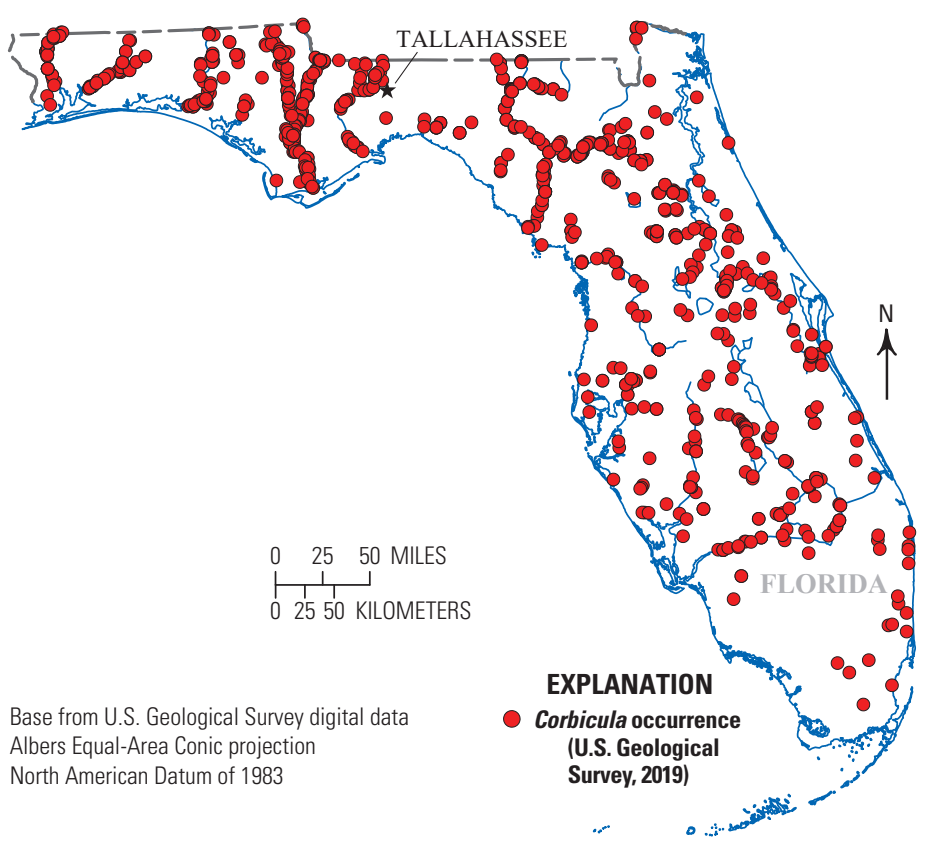

Figure 24. Corbicula spp. occurrences in Florida through 2019. 


\section{Georgia}

The earliest collection of Corbicula in Georgia was made in 1967 from the Flint River (UF 47004). Counts (1991) reported the earliest collection year as 1968 from the Altamaha River, but the year was actually 1971 (see Sickel, 1973). Remarkably, an average density greater than 9,000 individuals per square meter was reported in a section of the Altamaha River in 1974 (Gardner and others, 1976). Sixteen additional waterbodies with Corbicula collections through 1984 listed in Counts (1991) are Altamaha, Chattahoochee, Coahulla, Conasauga, Little Ocmulgee, Ocmulgee,

Ogeechee, Ohoopee, Oostanaula, Savannah, Towaliga, and Withlacoochee Rivers and Chickasawhatchee, Potato, Pound, and South Chickamauga Creeks. We found collections made prior to 1985 from 15 additional waterbodies not included in Counts (1991): Armuchee Creek (NCSM 55783), Cooleewahee Creek (NCSM 55812), Coosawattee River (NCSM 55662), Duck Creek (NCSM 55774), Etowah River (OSUM 36761), Johns Creek (NCSM 55806), Line Creek, Little Chickamauga Creek (NCSM 55648), Little River, Lookout Creek (NCSM 55768), Ochlockonee River (UF 46967), Radium Springs (NCSM 55707), Sawhatchee Creek (OSUM 35616), Stone Creek (LACM 1982-85.8), and West Chickamauga Creek (NCSM 55706).

After 1984, there were 32 additional rivers in Georgia with first-time Corbicula occurrences: Alapaha (UF 214623), Alapahoochee, Alcovy, Apalachee, Broad, Canoochee, Cartecay, Chattooga, Coosa, Coosawattee, Ellijay, Etowah, Jacks, Little, Little Ochlockonee, Little Ohoopee, Little Tallapoosa, Middle Oconee, Mulberry, New, North Oconee, Ochlockonee, Oconee, Satilla, South, South Branch Altamaha, South Fork Ogeechee, St. Marys, Tallapoosa, Tar, West Fork Little, and Yellow. First-time occurrence of Corbicula was also found nearly statewide in an additional 290 creeks after 1984, too numerous to list herein (USGS, 2019). Collection records are absent for the Okefenokee Swamp in southeastern Georgia, where water quality conditions such as low $\mathrm{pH}$ are not conducive for aquatic mollusks (Williams and others, 2014). Occurrences are also absent in drainages in extreme northeastern Georgia, which may be due to a lack of an introduction, suitable habitat, or sampling effort. On the basis of this review, Corbicula has been found in 44 of 52 HUC8 subbasins and 139 of 159 counties in Georgia (figs. 3, 5, 6, and 25).

\section{Hawaii}

The only collection locations of Corbicula in the State of Hawaii reported in Counts (1991) were an irrigation system at Hanalei National Wildlife Refuge in 1971 and Waita Reservoir in 1984, both on the island of Kaua' $i$. However, we believe that the 1971 date is too early. The date was based on a personal communication between D.E. Heacock, Hawaii Department of Land and Natural Resources, and C.L. Counts in 1985 as cited in Counts (1991). After searching museum collections and scientific literature, the earliest date we found was a museum voucher collection by D.E. Heacock made in 1982 from the irrigation ditches at Hanalei in Kaua'i (BPBM 207428). Furthermore, Devick (1991) summarized freshwater introductions on Hawaii and stated that the earliest date

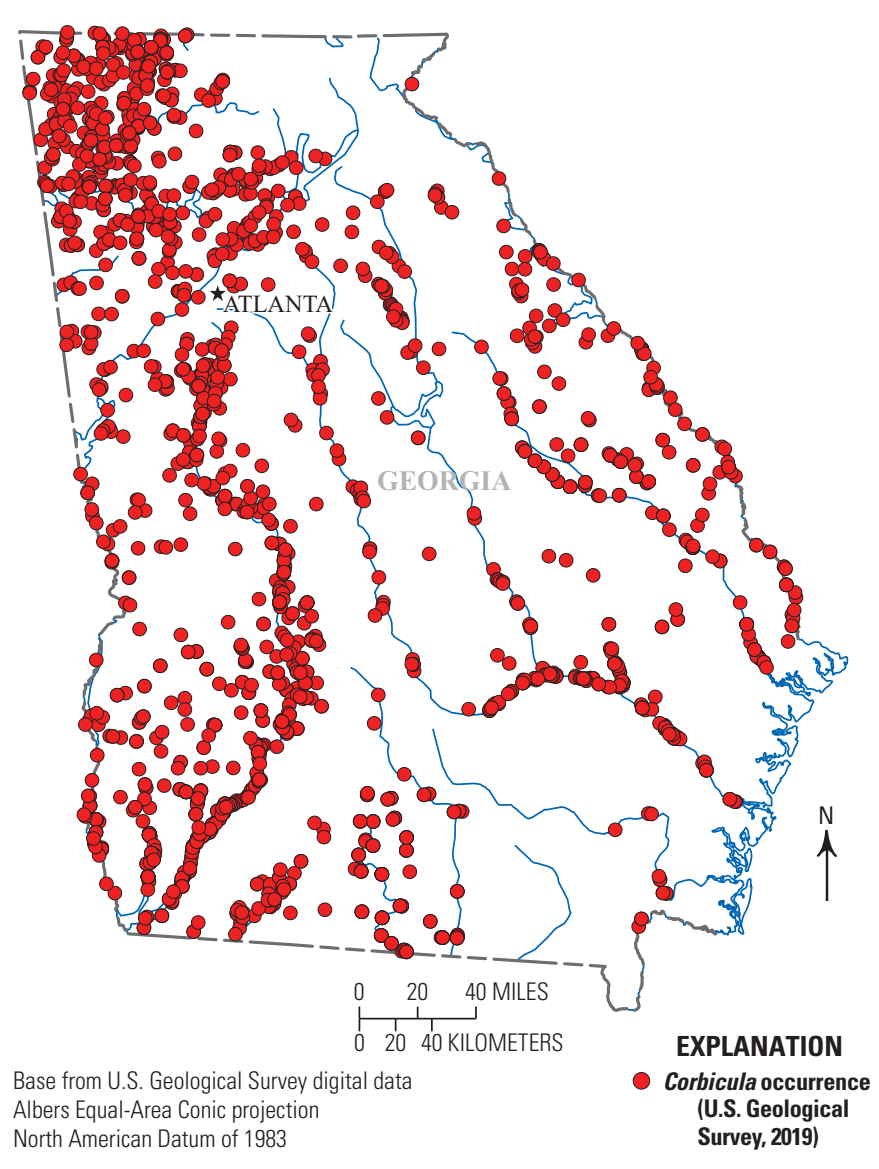

Figure 25. Corbicula spp. occurrences in Georgia through 2019.

for Corbicula on Kaua' $i$ was 1982. He stated the presence of Corbicula on the islands of Maui, O'ahu, and the Island of Hawai' $i$ in 1988, 1988, and 1989, respectively, but did not mention its presence in the State in 1971, nor did he indicate the extent of its distribution on the islands with specific locations. Corbicula was not observed at the Hanalei National Wildlife Refuge through the late 1970s by refuge personnel (V. Byrd, U.S. Fish and Wildlife Service, written commun., 2020).

After 1984, a limited number of collections was made in various locations on the four previously mentioned islands from 1988 to 2001. Specifically, the earliest collections in open waters on Maui (BPBM 209770) were from a commercial site in 1988 and Keālia Pond (BPBM 209833) in 1990. On O'ahu, also beginning in 1988, collection locations included Ho'omaluhia Park (BPBM 253396), Kamo'oali' ${ }^{\circ}$ Stream (BPBM 250462), Kapakahi Stream (BPBM 264925), Manoā Stream (BPBM 264931), Nu'uanu Stream (BPBM 254076), and Waikele Stream (BPBM 264940). On the Island of Hawai'i, Corbicula may have arrived by 1989 according 


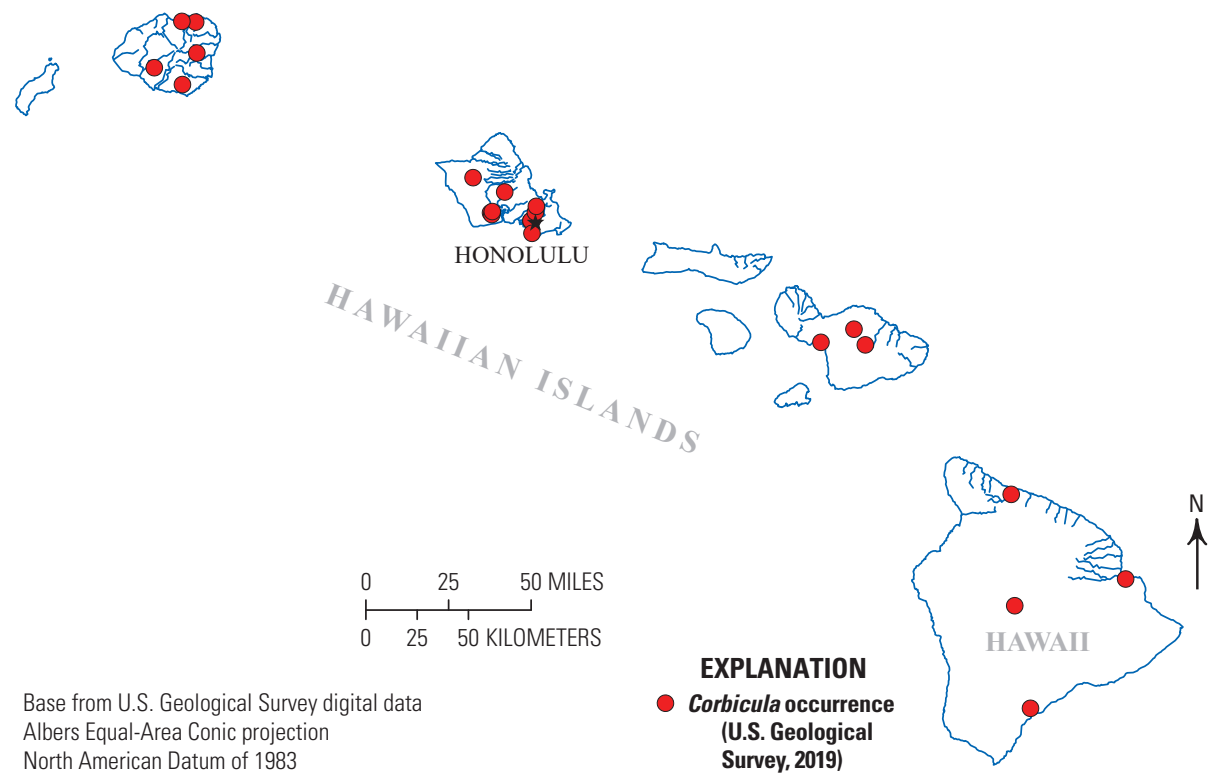

Figure 26. Corbicula spp. occurrences in Hawaii through 2019.

to Devick (1991), but the earliest museum collection locations included a coastal park pond in 1995 (INHS 18308) and Wailoa Stream in 2001 (BPBM 262078). A collection in an additional waterbody on Kaua'i was made in Wailua Reservoir (UCM 40414) in 1995. A pathway for Corbicula emerged when it was found for sale alive in an open market on $\mathrm{O}^{\text {'ahu }}$ in 1977 (Burch, 1978). An investigation showed that shipments were imported illegally from an exporter in California and directly from Asia (Burch, 1978). On the basis of this review, Corbicula has been found in 4 of 8 HUC 8 subbasins and 4 of 5 counties in Hawaii (figs. 3, 5, 6, and 26).

\section{Idaho}

An early publication by Ingram (1959) reported Corbicula as being in the Snake River located on the IdahoWashington border. Unfortunately, no collection year and specific location were provided. However, we found a collection made in 1955 from the Snake River at Homedale in the southwestern part of the State near the Oregon border (UMMZ 228099) that was not included in Counts (1991). This collection clearly placed Corbicula in the State in the mid-1950s. Several decades passed before Corbicula was again reported, as Counts (1991) included no other records, nor did we find any additional records for Idaho prior to 1985 .

In the late 1980s to early 1990s, Corbicula was collected for the first time from the middle portion of the Snake River between Milner Dam and C.J. Strike Reservoir, also in southwestern Idaho. Collections were also made in Big Creek in 2001 near the southern border with Nevada and in 2005 from the Pend Oreille River at the border with Washington. In 2007, Corbicula was found in dredged spoil piles removed from a canal next to the Bruneau River. Five years later, in 2012, more dredged spoil piles revealed shells along Alkali Drain in the Roswell Marsh Wildlife Management Area southwest of Parma near the Snake River. Again in 2012, Corbicula was collected from an established population in Lake Pend Oreille Lake at Ellisport Bay, a location near the Canadian border. From 2012 to 2016, additional waterbodies with first-time

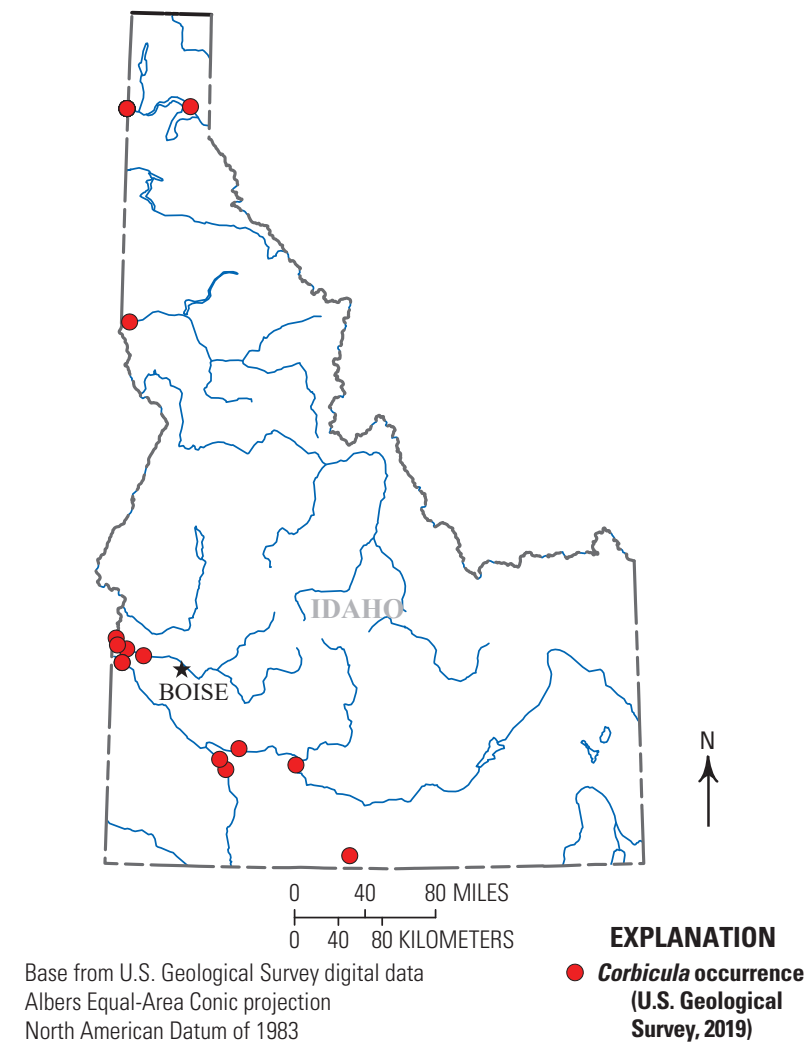

Figure 27. Corbicula spp. occurrences in Idaho through 2019. 
Corbicula occurrences include only locations from southwestern Idaho; they are the Bruneau River, Dixie Drain, Riverside Canal, and Sand Hollow Creek. On the basis of this review, Corbicula has been found in 9 of 85 HUC 8 subbasins and 7 of 44 counties in Idaho (figs. 3, 5, 6, and 27).

\section{Illinois}

The earliest collection of Corbicula in Illinois occurred in the Ohio River at Metropolis in 1960 (FMNH 103678: Fechtner, 1962). The location was just upriver from an earlier collection on the Kentucky side of the river in 1957 (Sinclair and Isom, 1961). Corbicula continued to disperse in the Ohio River along the State's southern border through the early 1980s. Counts (1991) listed collections in seven additional rivers, Illinois, Kankakee, Kaskaskia, Mississippi, Saline, Sangamon, and Wabash, and two creeks, Lick and Sugar. Also listed in Counts (1991) were Crab Orchard Lake, Dresden Cooling Lake, Sangchris Lake, and Lake Springfield, as well as seven powerplants and manufacturing facilities in eight counties. We found 15 waterbodies where collections were made from 1975 to 1984 but not included in Counts (1991): Baldwin Lake (INHS 43999), Cedar Creek (INHS 86085), Crab Orchard Creek (INHS 42341), Drury Creek (INHS 42346), Embarras River (INHS 19752), Grassy Creek (INHS 42339), Lake of Egypt (INHS 42333), Little Grassy Creek (INHS 42334), Little Grassy Lake (INHS 42335), Little Wabash River (INHS 19754), Main Ditch (INHS 19755), North Creek (INHS 90456), Piles Fork (INHS 42344), Tinley Creek (INHS 90513), and Ulrich Lake (INHS 44007).

After 1984, Corbicula was collected for the first time in 41 additional rivers in Illinois: Big Muddy (INHS 5656), Cache (INHS 2457), Dead (FMNH 316855), Des Plaines (INHS 567), DuPage (INHS 12037), East Branch Du Page (INHS 34558), East Branch Embarras (INHS 41831), East Fork Kaskaskia (INHS 39747), East Fork La Moine (INHS 42605), East Fork Mazon (INHS 34856), Elm (INHS 27381), Embarras (INHS 2484), Fox (INHS 42793), Iroquois (INHS 13082), Kaskaskia (INHS 19843), Little Embarras (INHS 32611), Little Marys (INHS 25815), Little Muddy (INHS 39645), Little Saline (INHS 22724), Little Vermillion (INHS 15684), Little Wabash (INHS 4741), Mackinaw (INHS 18269), Marys (INHS 23261), Mazon (INHS 11963), Middle Branch North Fork Vermilion (INHS 14661), Middle Fork Saline (INHS 17417), Middle Fork Vermilion (INHS 22287), North Branch Chicago (INHS 41228), North Fork Embarras (INHS 41853), North Fork Saline (INHS 6690), North Fork Vermilion (INHS 18027), Salt Fork Vermilion (INHS 3039), South Fork Saline (INHS 38553), South Fork Sangamon (INHS 7218), South Fork Vermilion (INHS 13035), Spoon (INHS 32262), Vermilion (INHS 3042), West Branch Du Page (INHS 19339), West Fork Mazon (INHS 34887), West Fork North Branch Chicago (INHS 41225), and West Okaw

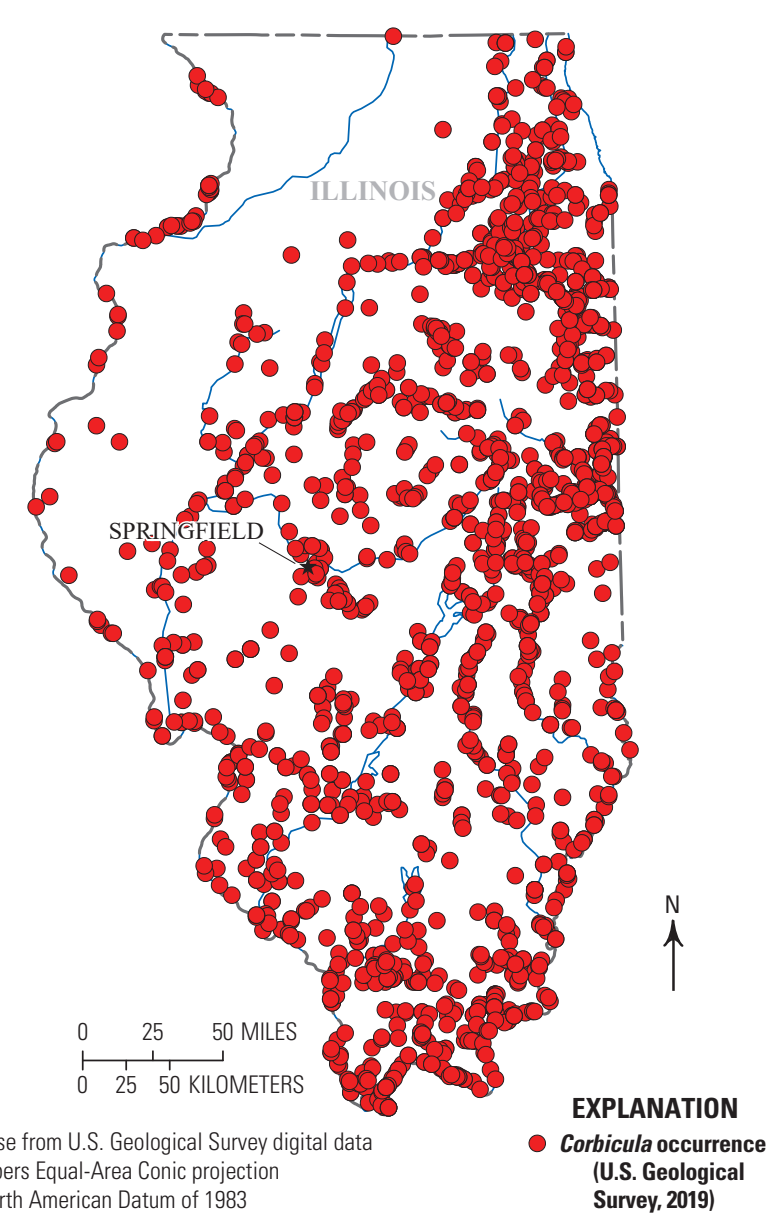

Figure 28. Corbicula spp. occurrences in Illinois through 2019.

(INHS 11744). In addition, Corbicula was found after 1984 for the first time in an additional 192 creeks, too numerous to list herein (USGS, 2019). In the Great Lakes, Corbicula was collected from Lake Michigan near Waukegan in 2009 (INHS 33675). Beginning in 2008, specimens identified as C. largillierti were collected from the Des Plaines, Du Page, Illinois, Kankakee, Mississippi, and Ohio Rivers (Illinois Natural History Survey, 2019; Douglass and others, 2020). In 2015, Tiemann and others (2017) identified the first Corbicula sp. Form D in the United States from the Illinois River near Marseilles (INHS 81868, UMMZ 305022). The large number of collections from Illinois rivers and creeks was likely due to surveys (for example, Stodola and others, 2014) with an emphasis on native freshwater mussel populations. On the basis of this review, Corbicula has been found in 49 of 52 HUC8 subbasins and 93 of 102 counties in Illinois (figs. 3, 5,6 , and 28). 
Indiana

The first reported collection of Corbicula in Indiana was in 1964 from the Ohio River (OSUM 14399), downriver from Evansville (see Counts, 1991). Ten years passed before another collection was reported, this time from the Wabash River in 1974 (INHS 46939). Counts (1991) listed additional collection locations in the Blue and White Rivers, as well as Big Indian, Indian, Salt, and Stony Creeks. We found collections from two additional waterbodies made prior to 1985 not included in Counts (1991), the Black River (OSUM 42482) and Sharpe Creek (OSUM 52847), both in 1978.

After 1984, Corbicula was found for the first time in the following 14 rivers: East Fork White (INHS 10502), Flatrock (INHS 8120), Kankakee (INHS 23835), Little Blue (INHS 15428), Little Vermilion (INHS 16225), Muscatatuck (OSUM 29926), Patoka (OSUM 55975), South Fork Blue (INHS 33573), Tippecanoe (INHS 1971), Vermilion, Vernon Fork Muscatatuck (INHS 13647), West Fork Blue (INHS 33615), White (INHS 8166), and Yellow (INHS 23842). Corbicula was collected for the first time from the following 28 additional creeks: Big (INHS 3922), Big Pine, Boggs (INHS 17086), Brandywine, Brouilletts (INHS 29130), Buck (INHS 10724), Clifty (INHS 17121), Coal (INHS 29167), Cypress (INHS 10400), Graham (OSUM 29950), Haw (INHS 17179), Indian (INHS 17057), Killbuck (INHS 8516), Little Sugar (INHS 10792), Mill (INHS 14473) (Dubois County), Mill (INHS 46107) (Owen County), North Fork Salt (INHS 17069), Oil (INHS 26365), Sand (INHS 15560), Smith, Snail (INHS 10769), Sugar (INHS 11250), Sulphur (INHS17065), Twin (INHS 19815), White (INHS 17048), Wildcat (INHS 8333), and Youngs (INHS 10815). In 2017, Corbicula was collected from Lake Michigan at Burns Harbor, as well as Indiana Harbor Canal and the adjacent Wolf Lake. Tiemann and others (2018) collected Corbicula sp. Form D from the Ohio River near Newburgh in 2015. On the basis of this review, Corbicula has been found in 28 of 38 HUC8 subbasins and 56 of 92 counties in Indiana (figs. 3, 5, 6, and 29).

\section{lowa}

The earliest reported occurrence of Corbicula in Iowa was in 1974 from the Mississippi River near Lansing at a powerplant's thermal effluent plume location (Eckblad, 1975). No other collections were reported until 1979, when a single specimen was taken from Cedar River, $6.5 \mathrm{~km}$ upstream from another powerplant (Counts, 1985b). Counts (1991) listed no other occurrences for Corbicula, nor did we find records for additional locations prior to 1985 .

After the early collections made in the 1970s, reports of occurrences were still very sparse in the State. However, the geographic

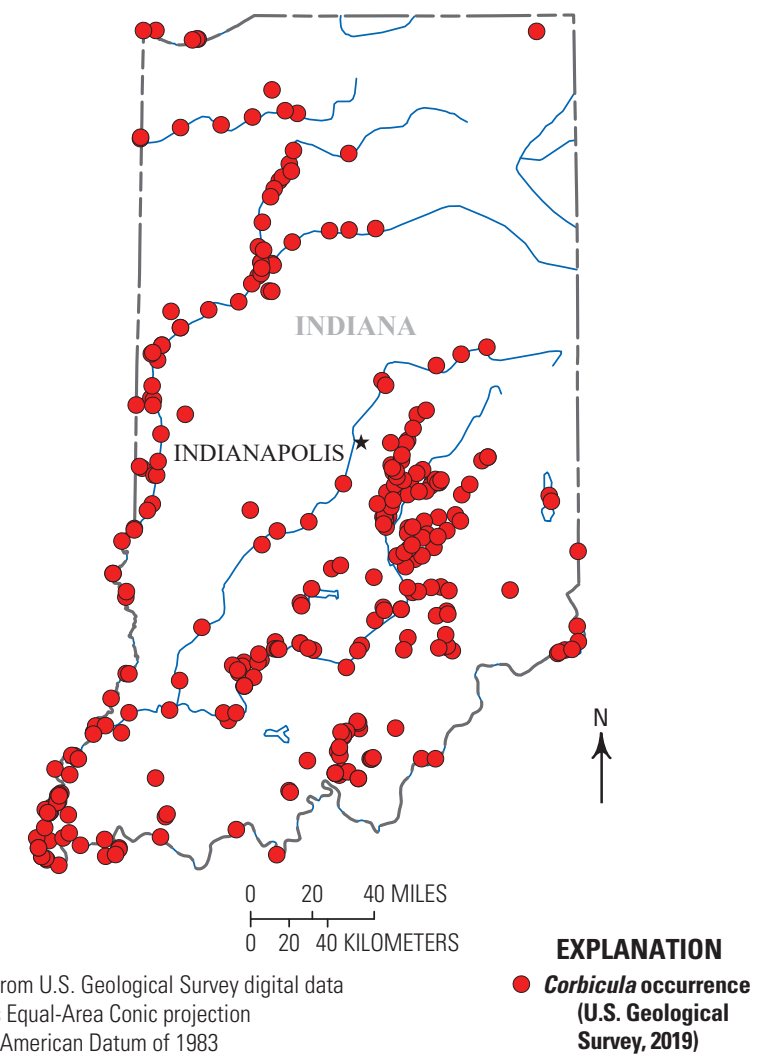

Figure 29. Corbicula spp. occurrences in Indiana through 2019. 
extent of Corbicula covered the entire length of the Mississippi River along the State's eastern border by 2019. Counties along the Mississippi River with first-time Corbicula collections after 1984 include Clayton, Clinton, Jackson (INHS 42247), Lee (INHS 32599), Louisa, Muscatine (INHS 82981), and Scott (INHS 43800). From 2003 to 2016, collection locations in the State include the following waterbodies: Des Moines, Iowa (INHS 87014), Missouri (NCSM 43442), and Skunk (INHS 89063) Rivers and also Pleasant Creek (INHS 90740), Slip Bluff, and Willow Reservoirs. Corbicula largillierti was collected from the Mississippi River near Bettendorf in 2012 (INHS 43804). Although the number of reported occurrences is relatively low, Corbicula occurs throughout the State in low densities and is considered a minor part of the benthic fauna (S. Gritters, Iowa Department of Natural Resources, written commun., 2018). On the basis of this review, Corbicula has been found in 12 of 57 HUC8 subbasins and 16 of 99 counties in Iowa (figs. 3, 5, 6, and 30).

\section{Kansas}

The earliest Corbicula collections in Kansas were made in 1983 by Mackie and Huggins (1983) in the Kansas River from Kansas City to Eudora and in four large reservoirs that geographically span the State: Cedar Bluff (Smoky Hill River), Cheney (North Fork Ninnescah River), Perry Lake (Delaware River), and Wilson Lake (Saline River). Counts (1991) listed no other records, nor did we find additional records of Corbicula for Kansas prior to 1985.

After 1984, there was a large increase in the number of waterbodies reported for the first time with Corbicula occurrences, and according to Angelo and others (2009), it is found in all major river basins in the State except for the upper Republican. However, a collection was made about 2004 from Keith Sebelius Lake, a reservoir on Prairie Dog Creek in the Republican River Basin (USGS, 2019). Collections have been made for the first time in the following 20 rivers:
Arkansas, Big Blue, Caney, Chikaskia, Cottonwood, Elk, Fall, Little Osage, Marias Des Cygnes, Medicine Lodge, Neosho, Ninnescah, North Fork Smoky Hill, Republican, Solomon, Spring, Verdigris, Wakarusa, Walnut, and West Branch Walnut. Corbicula has also been found for the first time in the following additional 45 creeks across the State after 1984: Badger, Bemis, Big South, Bluff, Buck, Bull, Burys, Cavalry, Cedar, Cherry, Cheyenne, Cowskin, Cross, Deer, Elm, Grouse, Gypsum, Hargis, Hundred and Ten Mile, Indian, Kill, Lightning, Little Cheyenne, Little Mill, Little Osage, Little Wakarusa, Long, Middle Caney, Mill, Mud (INHS 28493), Muddy, Mule, North Sugar, Pottawatomie, Sand, Sandy, Second Cow, Shoal, Silver, South Owl, Strowbridge, Tomahawk, Turkey, Washington, and Wolf. In addition to creeks, 52 reservoirs on creeks and small rivers have been found to have Corbicula for the first time: Big Hill Lake Reservoir (Big Hill Creek), Butler State Fishing Lake (North Branch Rock Creek), Strowbridge Reservoir (Strowbridge Creek), Centralia City Lake (unnamed creek), Chase County State Lake (Prather Creek), Clinton Lake (Wakarusa River), Douglas State Fishing Lake (Coal Creek), El Dorado Lake (Walnut River), Elk City Lake (Elk River), Elm Creek Lake (Elm Creek), Empire Lake (Spring River), Fall River Lake Reservoir (Fall River), Geary County State Lake (unnamed creek), Waconda Lake (Solomon River), Hargis Creek Lake (Hargis Creek), Harvey County East Park Lake (West Branch Whitewater Creek), Harvey County West Park Lake (unnamed creek), Heritage Park Lake, Hillsdale Lake (Wade Branch), Jeffrey Energy Center Auxiliary Lake, Jewell County State Lake (Ash Creek), Kanopolis Lake (Smoky Hill River), Keith Sebelius Lake (Prairie Dog Creek), Kingman State Fishing Lake, La Cygne Lake Reservoir (North Sugar Creek), Lake Fort Scott (Rock Creek), Gridley Lake (Varvel Creek), Lebo City Lake (unnamed creek), Leavenworth State Fishing Lake (unnamed creek), Logan City Lake (unnamed creek), Lone Star Lake (Washington Creek), Lyon County State Lake (unnamed creek), Madison City Lake (unnamed creek),

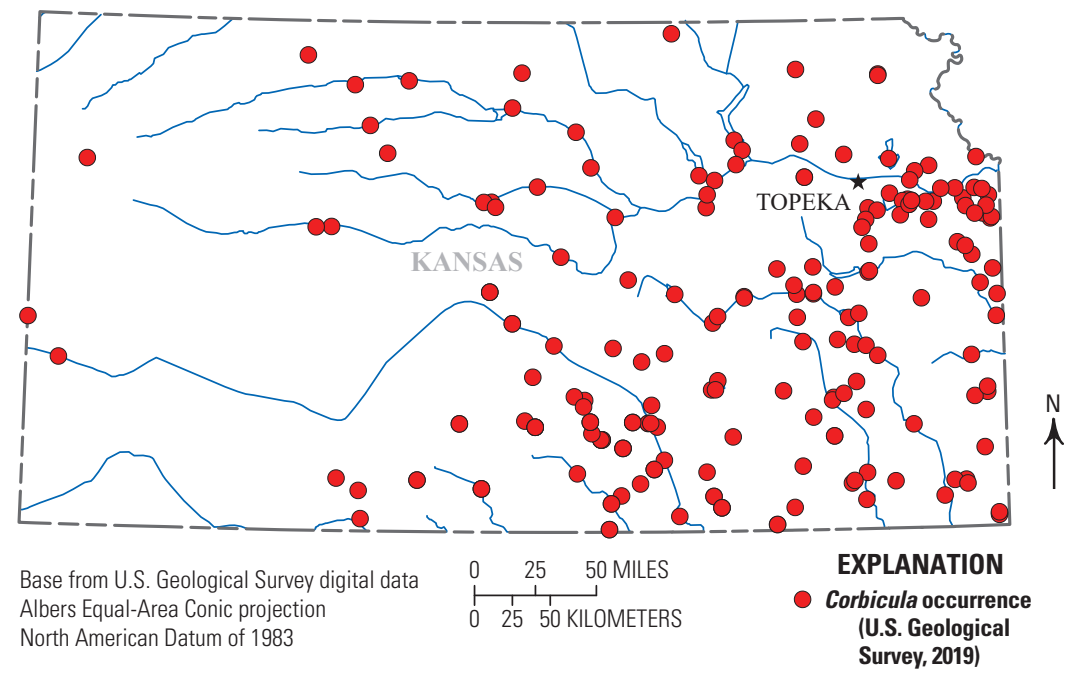

Figure 31. Corbicula spp. occurrences in Kansas through 2019. 
McPherson State Fishing Lake (Holderman Creek), Miami County State Lake, Middle Creek Lake (Middle Creek), Mined Land Wildlife Lakes, Miola Lake (Dorsey Branch), Montgomery State Fishing Lake (Coal Creek), Olathe Lake (Cedar Creek), Olpe City Lake (unnamed creek), Osage County Lake (unnamed creek), Plainville Lake (Paradise Creek), Shawnee Mission Lake (unnamed creek), Shawnee State Fishing Lake (unnamed creek), Toronto Lake (Verdigris River), Tuttle Creek Lake (Blue River), Washington State Fishing Lake (Devils Creek), Wellington City Lake (East Prairie Creek), Wilson State Fishing Lake (Woodruff Branch), Woodson State Fishing Lake (unnamed creek), and Wyandotte County Lake (Marshall Creek). On the basis of this review, Corbicula has been found in 51 of 90 HUC8 subbasins and 62 of 105 counties in Kansas (figs. 3, 5, 6, and 31).

\section{Kentucky}

The earliest collection of Corbicula in Kentucky was in 1957 from the Kentucky side of the Ohio River near Paducah (Sinclair and Isom, 1961). This was the first reported occurrence east of the Continental Divide and the Mississippi River drainage. Its presence likely represented a human-mediated overland dispersal from a western State as suggested by McMahon (1982). From 1957 through 1984, Counts (1991) listed Corbicula as having been collected in the following 16 additional rivers: Big Sandy, Cumberland, Dix, Gasper, Green, Kentucky, Licking, Little, Mississippi, Mud, Nolin, Red, Rockcastle, Salt, Tennessee, and Tradewater. Early collection locations in creeks include Buck, Eagle, Elkhorn, Floyds Fork, Horse Lick, Kinniconick, Silver, Slate, and Tygart (see Counts, 1991). We found collections for 10 additional waterbodies as early as 1968 not included in Counts (1991): Barren River (OSUM 82410), Drake Creek (ANSP 358900), Pond River (OSUM 50186), Little Barren River (OSUM 83738), Little South Fork (OSUM 42822), Middle Fork Drakes
Creek (ANSP 358890), Big South Fork Cumberland River (OSUM 45469), South Fork Little River (OSUM 49287), West Fork Red River (OSUM 27050), and Whippoorwill Creek (OSUM 82614).

After 1984, the following nine additional rivers and creeks were reported with first-time occurrences of Corbicula: Beech Fork (INHS 16063), Chaplin River (INHS 12884), Jessamine Creek (INHS 12777), Jonathan Creek (INHS 21441), Little Sexton Creek (OSUM 65344), Poor Fork Cumberland River (INHS 12753), Red Bird Creek (INHS 5667), Sturgeon Creek (INHS 16042), and West Fork Clarks River (INHS 12769). Corbicula largillierti was collected in 2013 from the lower Ohio River near the mouth (INHS 45639). In 2017, a single live specimen of Corbicula sp. Form D was collected in the lower Ohio River (INHS 87523: Tiemann and others, 2018), and Douglass and others (2020) reported Form D from the Tennessee River in 2018 (INHS 89761). On the basis of this review, Corbicula has been found in 32 of 44 HUC8 subbasins and 74 of 120 counties in Kentucky (figs. 3, 5, 6, and 32).

\section{Louisiana}

The first reported collection of Corbicula in Louisiana occurred in the Calcasieu River in 1961 followed by collections in Bayou Sorrel and Bayou Magazille, both in 1962 (Dundee and Harman, 1963). In addition to these early occurrences, the following waterbodies where Corbicula was found prior to 1985 are listed in Counts (1991): Amite, Atchafalaya, Pearl, Mississippi, Pearl, Red, Sabine, Tensas, and West Pearl Rivers, along with Carron, Cocodrie, Teche, and Wauksha Bayous. Although the spatial extent was broad in the State prior to 1985, Corbicula occurrence was not reported from a large number of distinct waterbodies. However, we found collections as early as 1964 from 17 additional waterbodies not included in Counts (1991): Bayou Boeuf (OSUM 80794),

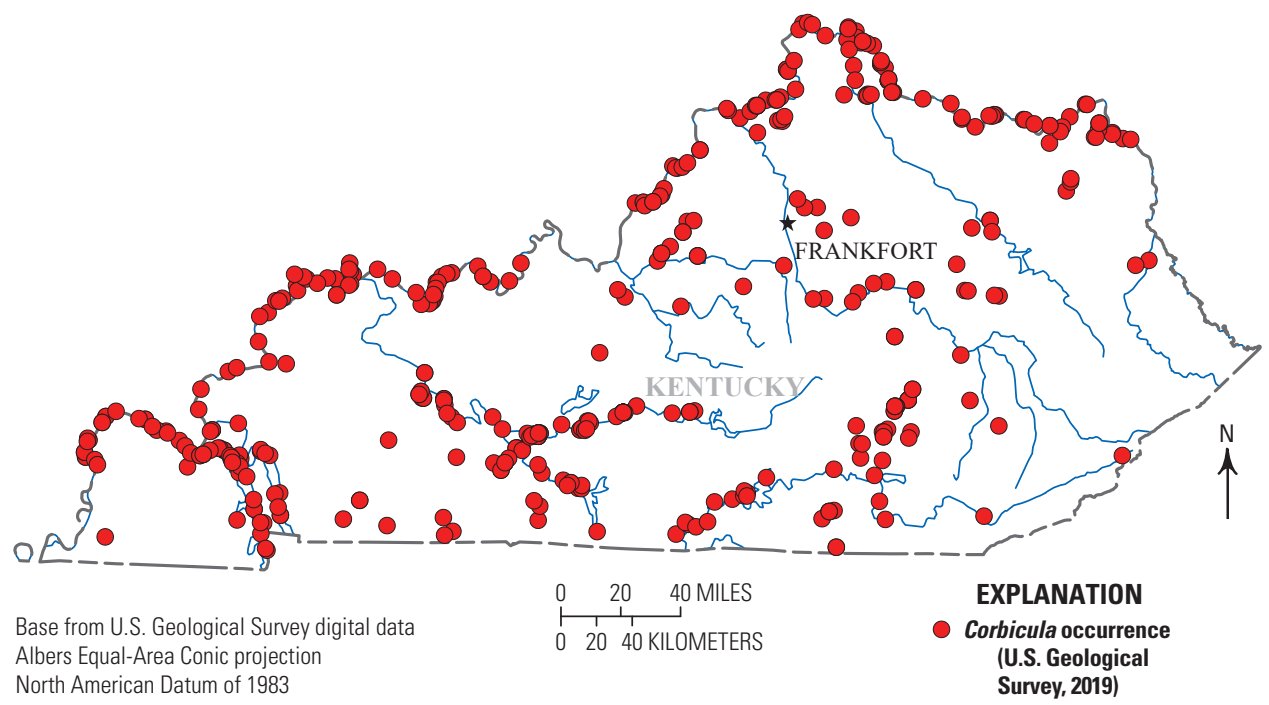

Figure 32. Corbicula spp. occurrences in Kentucky through 2019. 
Bayou Maringouin (OSUM 78114), Bogue Chitto (MMNS 13215), Chappepeela Creek (OSUM 78291), Comite River (OSUM 78255), Hemphill Creek (MMNS 12410), Holmes Bayou (MMNS 12587), Loggy Bayou (OSUM 78244), Natalbany River (OSUM 78127), Ouachita River (MMNS 13215), Red Chute Bayou (OSUM 78252), Tangipahoa River (OSUM 77973), Tenmile Creek (MMNS 12348), Tickfaw

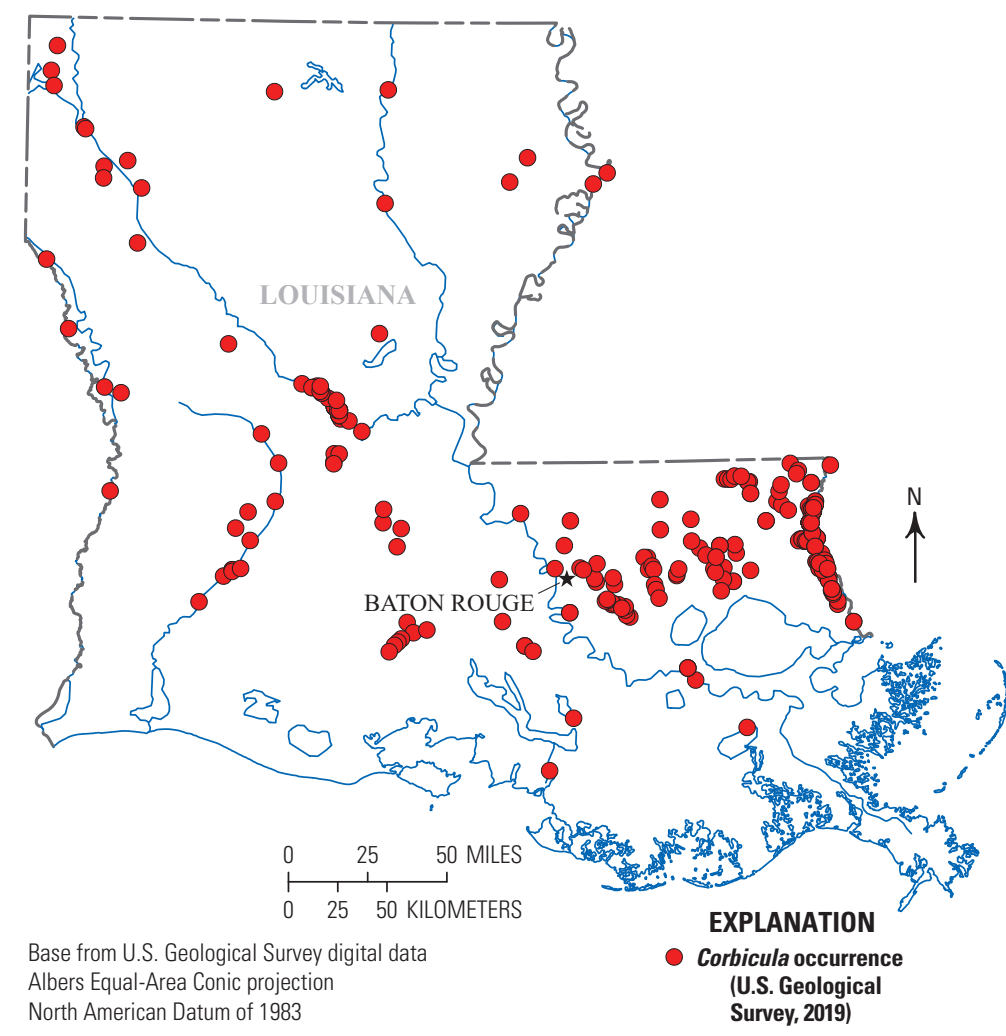

Figure 33. Corbicula spp. occurrences in Louisiana through 2019.

River (OSUM 78109), West Colyell Creek (OSUM 78272), Whiskey Chitto Creek (MMNS 12349), and Wilson Slough (MMNS 12638).

After 1984, an additional 22 waterbodies were found to have occurrences of Corbicula for the first time: Bayou Grosse Tete (NCSM 55652), Bayou Pierre (USAO 5961), Bayou Toro (USAO 6019), Bedico Creek, Black Bayou (USAO 5913), Bogue Falaya, Bogue Lusa Creek, Cane River (NCSM 55687), Deer Lick Creek, Hays Creek, Hog Branch, Lake Salvador, Munroe Creek, Pushepatapa Creek (MMNS 13014), Redwood Creek (OSUM 28839), Silver Springs Creek, Sims Creek (NCSM 55761), South Canal (OSUM 28840), Tchefuncte River, Twelvemile Bayou (USAO 5950), Vermilion River, and Washley Creek. On the basis of this review, Corbicula has been found in 32 of 57 HUC8 subbasins and 33 of 64 parishes in Louisiana (figs. 3, 5, 6, and 33).

\section{Maryland}

The earliest reported Corbicula collection in Maryland occurred in 1975 at the mouth of the Susquehanna River (Chesapeake Bay) near Havre de Grace (Stotts and others, 1977, as cited in Counts, 1991). Other waterbodies with Corbicula included in Counts (1991) are Choptank River, Nassawango Creek, Potomac River, Susquehanna River, and Wicomico River. We found collections made from nine additional waterbodies prior to 1985 not included in Counts (1991): Antietam Creek, Casselman River, Double Pipe Creek, Gunpowder River, Licking Creek, Monocacy River, Pocomoke River, Seneca Creek, and Town Creek.

After 1984, Corbicula dispersed into rivers and creeks across the entire State, including the Delmarva Peninsula. First-time occurrences in additional waterbodies include the following 19 rivers: Chester (ANSP 37686), East Branch North Branch Patapsco, Hawlings, Little Gunpowder Falls, Little Monocacy, Little Patuxent, Magothy, Middle Patuxent, North Branch Casselman, North Branch Patapsco, North Branch Potomac, North East, Northeast Branch Anacostia, Northwest Branch Anacostia, Patapsco, Patuxent, South Branch Patapsco, Tred Avon, and Western Branch Patuxent. Corbicula was found for the first time in the following additional 151 creeks: Andover Branch, Back (on Spesutie Island), Ballenger, Bear Branch, Beaver, Beaver Dam, Beaverdam Ditch, Bennett, Big Elk, Big Pipe, Birch Branch, Blinkhorn, Brice Run, Broad, Broad Run, Browns Branch, Bucklodge Branch, Bush, Bynum Run, Cabin John, Catoctin, Cherry, Conococheague, Conowingo, Cypress Branch, Davis Branch, Dead Run, Deep Run, Deer, Dividing, Dogwood Run, Dorsey Run, Dry Seneca, East Fork Langford, Evitts, Faulkner Branch, Fifteen Mile, Fishing, Flat Run, Forest Grove Branch, Forge Branch, Fowling, Gales, Gilbert Swamp Run, Gillis Falls, Gravelly Branch, Grays Run, Great Seneca, Gunners Branch, Gwynns Falls, Haines Branch, Hammond Branch, Hatchery Run, Highfield, Hunting, Island, James Run, Jones Falls, Kings, Lake Chambers, Leonard Pond Run, Linganore, Little Bohemia, Little Catoctin, Little Conococheague, Little Deer, Little Elk, Little Gunpowder Falls, Little Pipe, Little Seneca (CMNH 120050), Long Green, Lottsford Branch, Marsh, Marsh Run, Marshyhope (ANSP 376373), Mason Branch, Mataponi, Mattawoman, McIntosh Run, Meadow Branch Big Pipe Creek, Meadow Brook, Middle, Middle Neck Branch, Middle Run, Mill Run, Mill Stream Branch, Minnehaha Branch, Morgan, Morgan Run, Morris Prong, Muddy Branch, North Branch Rock Creek, North East, North Fork Green Run, Norwich, Octoraro (ANSP 376380), Otter Point, Owens, Peggy Branch, Pilchard (ANSP 376381), Piney, Piney Branch, Piney Run, Piscataway, Red Hill Branch, Red Lion Branch, Rewastico, Rock, Rock Run, Rockburn Branch, Sams, Sandy Branch, Seven Springs Run, Severn Run, Sewell Branch, 


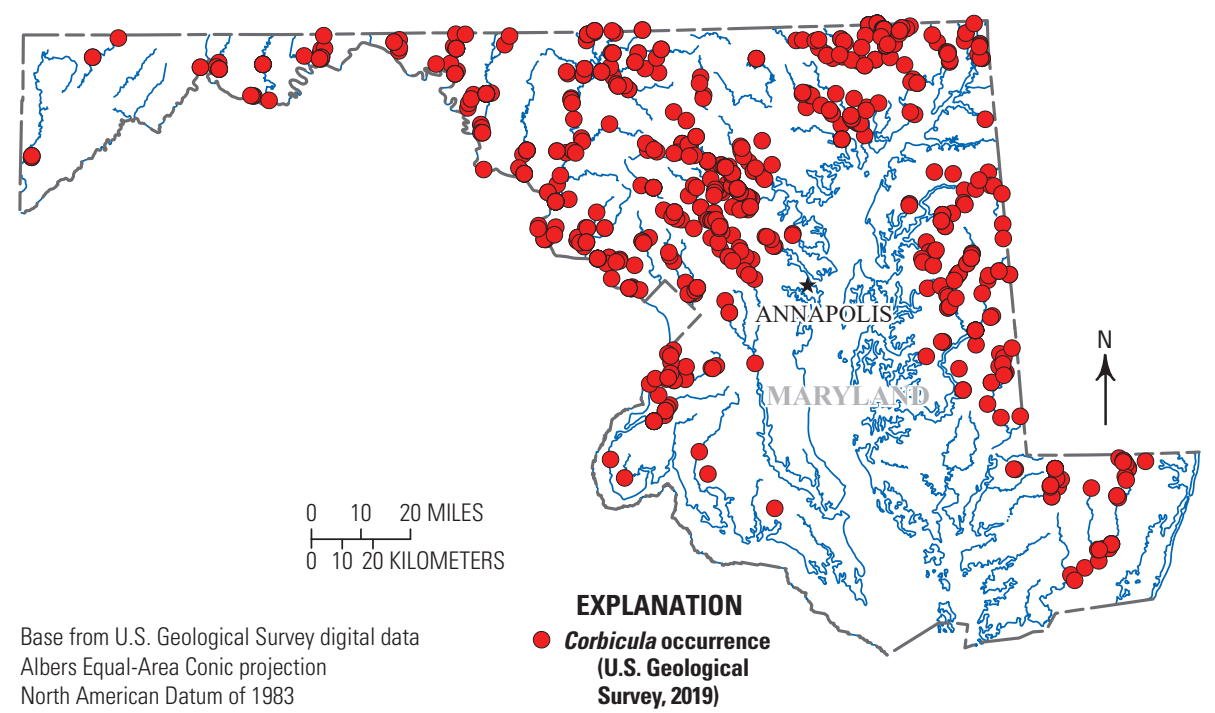

Figure 34. Corbicula spp. occurrences in Maryland through 2019.

Sharmans Branch, Sideling Hill, Skinners Run, Snowden Run, South Branch Patapsco, Southeast, Stone Run, Sullivan Branch, Three Bridges Branch, Tiber Branch, Tidy Island, Toms, Tuckahoe (ANSP 376384), Tull Branch, Tuscarora, Unicorn Branch, unnamed tributary of Broad Creek, unnamed tributary of Browns Branch, unnamed tributary of Chester River, unnamed tributary of Deep Run, unnamed tributary of Liberty Lake, unnamed tributary of Mallows Bay, unnamed tributary of Marshyhope Creek, unnamed tributary of Big Pipe Creek, unnamed tributary of Middle Patuxent River, unnamed tributary of Nanjemoy Creek, unnamed tributary of Patuxent River, unnamed tributary of Southeast Creek, unnamed tributary of Three Bridges Branch, unnamed tributary of Tony Tank Pond, unnamed tributary of Tuckahoe Creek, unnamed tributary of Wye East River, Watts Branch, Watts Creek, Zekiah Swamp Run, and Chesapeake Bay (at Spesutie Island Narrows). On the basis of this review, Corbicula has been found in 19 of 24 HUC 8 subbasins and 23 of 24 counties in Maryland (figs. 3, 5, 6, and 34).

\section{Michigan}

The first collection of Corbicula in Michigan was from western Lake Erie near the city of Monroe in 1980; it also represented the first record from the Laurentian Great Lakes system of the United States and Canada (Clarke, 1981). The author noted that Corbicula was not likely to survive cold water temperatures in the very shallow nearshore location where he made his collection of two living juvenile specimens, but perhaps it could in deeper, and potentially warmer, waters of the lake if other larvae settled there. There was no mention of possible thermal refugia near the Lake Erie collection site. Additional collections in Lake Erie (OSUM 52734, USNM 803157) were made in the same vicinity the following year. In 1983, Corbicula was found for the first time in a second Great Lake, Lake Michigan, at a location just offshore of a powerplant west of Grand Rapids (White and others, 1984). Counts (1991) listed no other records for the State, nor did we find any additional collections made prior to 1985 .

After 1984, collections of Corbicula were made for the first time in the St. Clair River in 1986, Clinton River in 1990, Lake Superior (INHS 15674) in 1994, Davis Creek (UMMZ 300014) in 1999, and Eagle Creek in 2000. The 1994 collection from Lake Superior was near the city of Marquette in the upper peninsula of the State and the first for this Great Lake. Both the Lake Superior and the St. Clair River collections were taken in thermal effluent near powerplants. The distribution of Corbicula occurrences had been very limited until the early 2010s, when it was reported for the first time in the following 34 waterbodies: Buck Creek, Cass Lake, Coldwater Lake, Devils Lake, Diamond Lake, Eagle Lake, Flint River, Ford Lake, Grand River, Hayworth Creek, Higgins Lake, Kent Lake, Klinger Lake, Lake Cora, Lake Fenton, Lake Lancer,

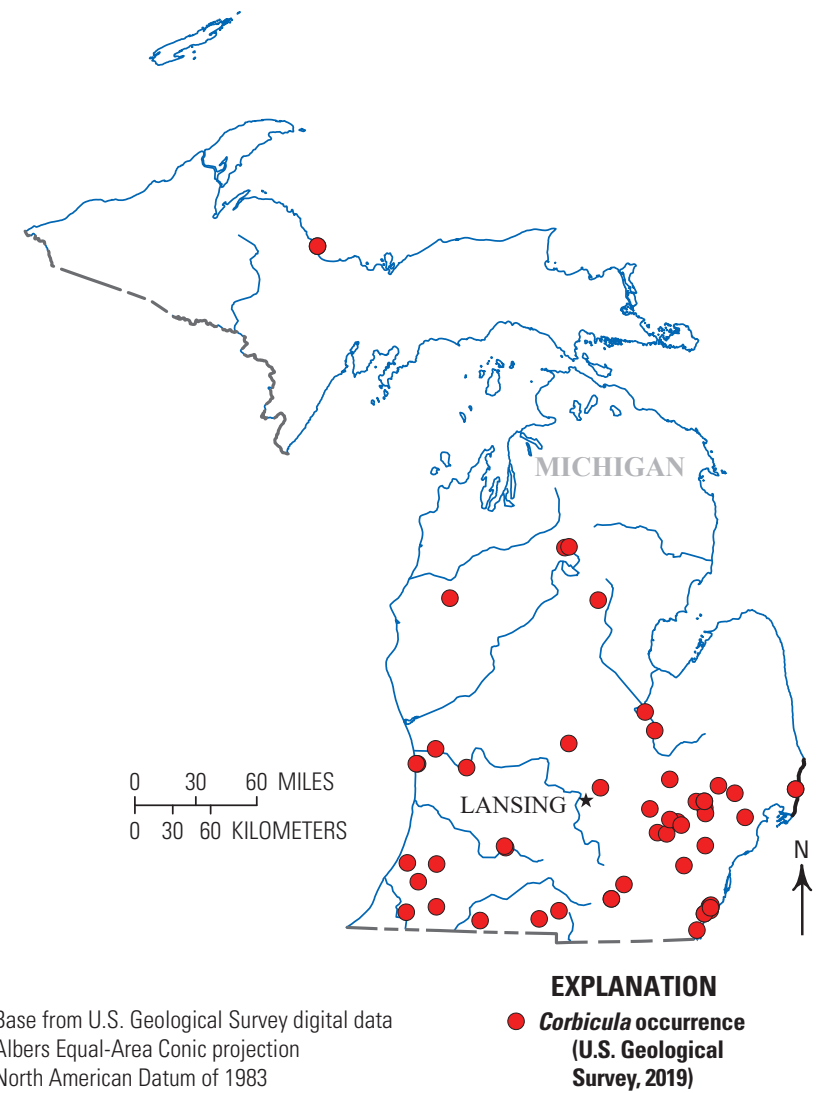

Figure 35. Corbicula spp. occurrences in Michigan through 2019. 
Lake Lansing, Lake Orion, Little Manistee River, Long Lake, Magician Lake, Mann Creek, Middle River Rogue, Orchard Lake, Paw Lake, Pontiac Lake, Red Run, Round Lake, St. Joseph River, Stony Creek Lake, Strawberry Lake, Thompson Lake, Wamplers Lake, and Whitmore Lake. With the exception of Lake Superior and Little Manistee River, all other collection locations have been predominantly in the southern part of the State. The Buck Creek and Flint River locations were noteworthy because of cold winter temperatures typically present in the area. Many specimens were collected from each waterbody even though no thermal refugia were believed to be present. In the Clinton River, densities of greater than 1,000 individuals per square meter were achieved after surviving freezing winter temperatures (Janech and Hunter, 1995). This density is indicative of reproduction where it was thought that winter temperatures would be lower than cold tolerance of Corbicula. On the basis of this review, Corbicula has been found in 21 of 60 HUC 8 subbasins and 25 of 83 counties in Michigan (figs. 3, 5, 6, and 35).

\section{Minnesota}

The first reported collection of Corbicula in Minnesota was made in 1978 from the Minnesota River, just downstream from a powerplant near the Minneapolis and St. Paul area (Cummings and Jones, 1978). Although an earlier collection was made from the St. Croix River (the border with Wisconsin) east of St. Paul in 1977 (Fuller, 1978), it was on

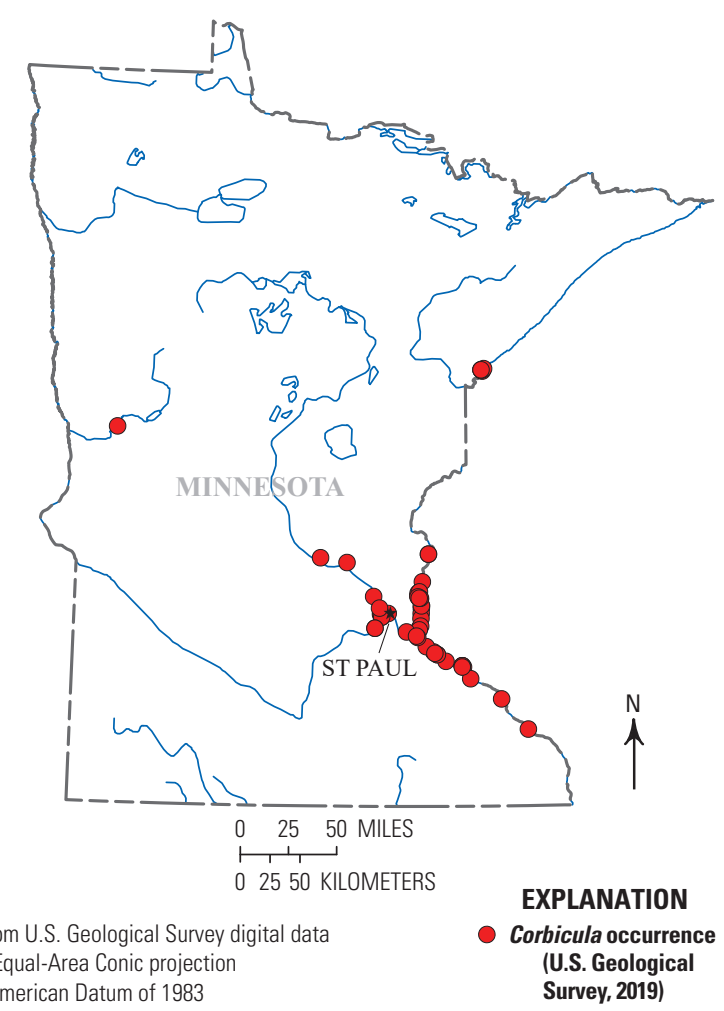

Albers Equal-Area Conic projection North American Datum of 1983

Figure 36. Corbicula spp. occurrences in Minnesota through 2019.

the Wisconsin side of the river. Counts (1991) listed no other records for Corbicula, nor did we find additional records for Minnesota prior to 1985.

In 1987, Corbicula was collected over a nearly $5-\mathrm{km}$ stretch of the St. Croix River (JFBM 10892, 11429). The earliest reported collection in the Mississippi River occurred in 1988 above Lock and Dam 3 near a nuclear powerplant (JFBM 4304). Occurrences were reported from more than 20 locations in the Mississippi River from St. Paul downriver to Kellogg through 2013. In 1999, a sample of approximately 100 specimens was collected from the St. Louis River near a wastewater treatment plant in Duluth near Lake Superior. Trebitz and others (2010) also reported finding numerous Corbicula specimens in 2006 in the vicinity of Duluth Harbor Basin but only near a wastewater treatment outfall. Corbicula was reported for the first time in the Otter Tail River in a powerplant thermal effluent plume in 2018 (JFBM 22914). This collection location in west-central Minnesota was a first for the entire Red River of the North drainage. On the basis of this review, Corbicula has been found in 8 of 80 HUC 8 subbasins and 13 of 87 counties in Minnesota (figs. 3, 5, 6, and 36).

\section{Mississippi}

The earliest reported collection of Corbicula in Mississippi was in 1963 from the Pearl River (MMNS 12465) and was not mentioned in Counts (1991). In a matter of just days after this collection, Corbicula was found in the Yazoo River (FMNH 137777) (see Counts, 1991). Corbicula quickly became widespread across the State in all major river drainages by the mid-1980s. The following 41 waterbodies with Corbicula occurrences are listed in Counts (1991): Allan Branch, Bayou Pierre, Bear Creek, Big Black Creek, Big Black River, Big Sunflower River, Black Creek, Bogue Chitto River, Bogue Homa River, Bogue Phalia River, Buckatunna Creek, Bull Mountain Creek, Buttahatchee River, Chickasawhay River, Chunky River, Chuquatonchee Creek, Coldwater River, Deer Creek, Ferguson Lake, Hanging Moss Creek, Lake Bolivar, Lake Washington, Leaf River, Luxapallila Creek, Mississippi River, Noxubee River, Okatibbee Creek, Okatoma Creek, Pascagoula River, Pelahatchie Creek, Shubuta Creek, Souenlovie Creek, Steele Bayou, Strong River, Tallahala Creek, Tangipahoa River, Tibbee Creek, Tombigbee River, West Fork Amite River, Woodward Creek, and Yalobusha River. We found collections made prior to 1985 from 11 additional waterbodies not included in Counts (1991): Clear Creek (MMNS 11737), Doaks Creek (MMNS 11743), Tombigbee River (OSUM 34835), Fivemile Creek (MMNS 11738), Lobutcha Creek (MMNS 12853), Mackeys Creek (OSUM 35781), Magowah Creek (MMNS 6274), Sardis Reservoir (DMNH 120705), Seneasha Creek (MMNS 11745), Yockanookany River (OSUM 78126), and Yocona River.

After 1984, Corbicula was collected for the first time in 22 additional waterbodies in Mississippi including Bay Springs Lake (MMNS 9562), East Fork Amite River (MMNS 
6400), Fish Lake, Hatchie River (MMNS 7482), Homochitto River (MMNS 8991), Hushpuckena River (MMNS 5152), Lake Chotard (MMNS 8504), Lake Lee (MMNS 8740), Lake Mary (MMNS 9551), Little Hatchie River (MMNS 11755), Little Noxubee River (MMNS 9140), Little Tallahatchie River (MMNS 11899), Quiver River (MMNS 5378), Skuna River (MMNS 10770), St. Catherine Creek National Wildlife Refuge waters (MMNS 6902), Sucarnoochee River (MMNS 10694), Tallahatchie River (MMNS 9809), Tennessee River (MMNS 8336), Tickfaw River (MMNS 6416), Tippah River (MMNS 9125), Wolf River (MMNS 4931), and an unspecified waterbody at Panther Swamp National Wildlife Refuge (MMNS 6880). After 1984, the following 62 creeks in Mississippi were found to have first-time occurrences of Corbicula: Alamucha (MMNS 7767), Bagley (MMNS 7616), Bala Chitto (MMNS 9676), Big Spring (MMNS 8244), Bogue Homa (MMNS 13058), Cane (MMNS 12988), Chewalla (MMNS 8248), Coonewah (MMNS 8910), Copiah (MMNS 13555), Dicks (MMNS 8906), Dowling Bayou (MMNS 9300), Durden (MMNS 10765), Euclautubba (MMNS 8936), Gilliam Chute (MMNS 3830), Gin (MMNS 10975), Goodford (MMNS 9006), Hobuck (MMNS 7655), Jones Bayou (MMNS 7148), Kentuctah (MMNS 7659), Kincaide (MMNS 6851), Lake Cormorant Bayou (MMNS 9424), Long (MMNS 7720),

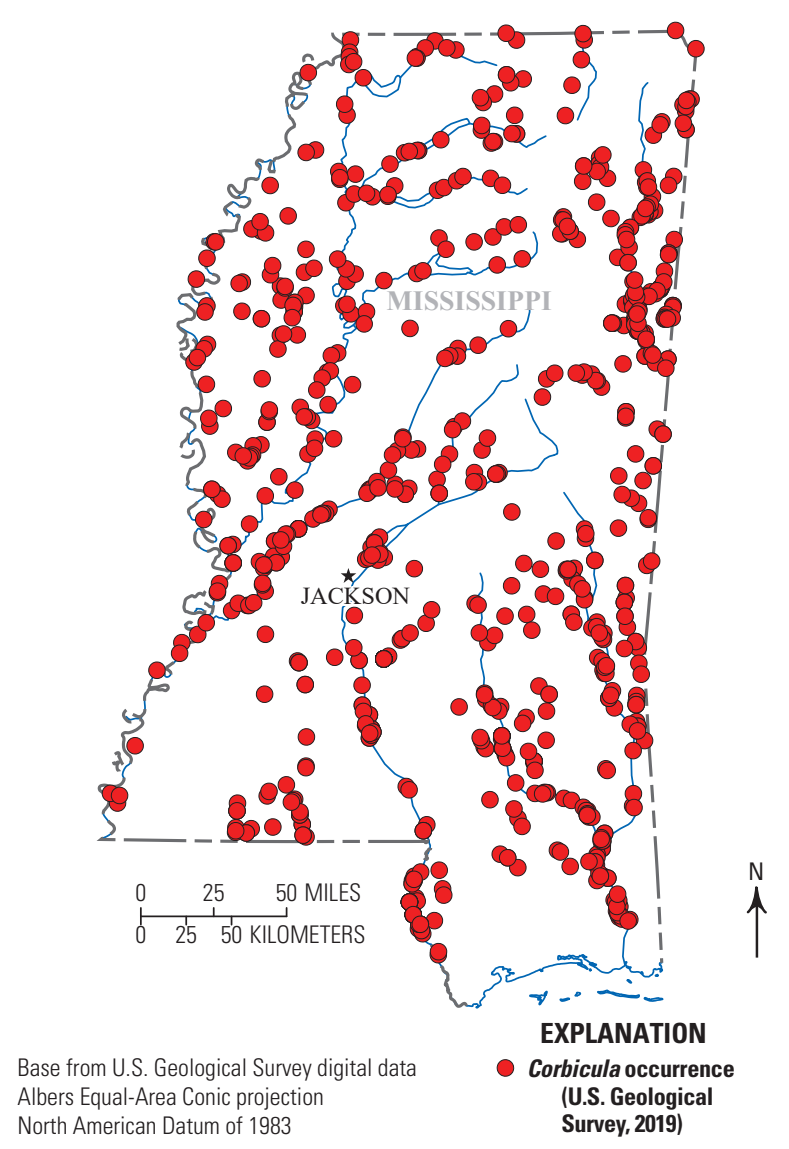

Figure 37. Corbicula spp. occurrences in Mississippi through 2019.
Loves (MMNS 7657), Mattubby (MMNS 8878), Mill (MMNS 10866), Mitchell (MMNS 8253), Mountain (MMNS 13540), Mud (MMNS 7505), Oktoc (MMNS 11875), Pawticfaw (MMNS 10670), Ponta (MMNS 7609), Poplar (MMNS 13537), Porter Bayou (MMNS 4551), Puskus (MMNS 9023), Quarterliah (MMNS 13562), Red (MMNS 6606), Richies Bayou (MMNS 10583), Rochester (MMNS 9102), Rolling Fork (MMNS 7702), Sand (MMNS 8001), Shy Hammock (MMNS 10704), Sipsey (MMNS 8380), Snake (MMNS 7034), Summer Seat (MMNS 11761), Tallahatta (MMNS 9143), Tchula Lake Cutoff Canal (MMNS 5079), TennesseeTombigbee Waterway (INHS 5163), Teoc (MMNS 9895), Tesheva (MMNS 6424), Thompson (MMNS 12989), Tishkill (MMNS 9101), Town (MMNS 6029), Tulip (MMNS 7504), Turkey Fork (MMNS 9108), Wahalak (MMNS 10682), Walls (MMNS 8930), West Hobolochitto (MMNS 10209), West Tallahala (MMNS 8866), Whites (MMNS 7724), Wild Bill Bayou (MMNS 13564), and Yellow (MMNS 5757). On the basis of this review, Corbicula has been found in 44 of 50 HUC8 subbasins and 76 of 82 counties in Mississippi (figs. 3, 5,6 , and 37).

\section{Missouri}

The earliest known collection of Corbicula in Missouri was believed to be in 1962 from a drainage ditch near Gideon (OSUM 6817) in the southeastern corner of the State (see Counts, 1991). However, we found that the earliest collection in the State may have been one year earlier. Stein (1962) compiled collection records from the lower Ohio River drainage and cited a collection made in 1961 from the "Mississippi River, Louisiana" (OSUM 4416). Louisiana is a town in Missouri along the upper Mississippi River north of St. Louis. This town's name may have been confused with the State name as it was included in the State of Louisiana and not in the State of Missouri in Counts (1991). A collection was made from the Illinois side of the Mississippi River across from Louisiana, Missouri, in 2012 (INHS 43876) confirming their presence albeit a later date. Counts (1991) listed collections from 1964 to 1984 in 19 waterbodies: Big, Black, Bourbeuse, Current, Gasconade, Little Black, Meramec, Middle Fork Little Chariton (Thomas Hill Reservoir), Mississippi, Missouri, Moreau, Osage, St. Francis, and Upper Castor Rivers, and Big, Bryant, Cane, Logan, and Upper Whitewater Creeks. We found collections made prior to 1985 from the following 16 waterbodies as early as 1962 not listed in Counts (1991): Beaverdam Creek, Big Piney River, Crooked Creek, Eleven Point River, Finley Creek, Fish Lake Ditch, Frederick Creek, Indian Creek (OSUM 41572), Jacks Fork River, James River, Kings River, Maries River, Rocky Creek, Spring River (OSUM 58911), Tavern Creek, and Tenmile Creek.

After 1984, 25 additional rivers were found to have firsttime Corbicula occurrences in Missouri: Big Piney, Cuivre, East Fork Black, Eleven Point, Elk, Jacks Fork, Lamine, Little Niangua, Marais des Cygnes, North Prong Little Black, Niangua, North Fork Spring, North Fork, North Prong Little 


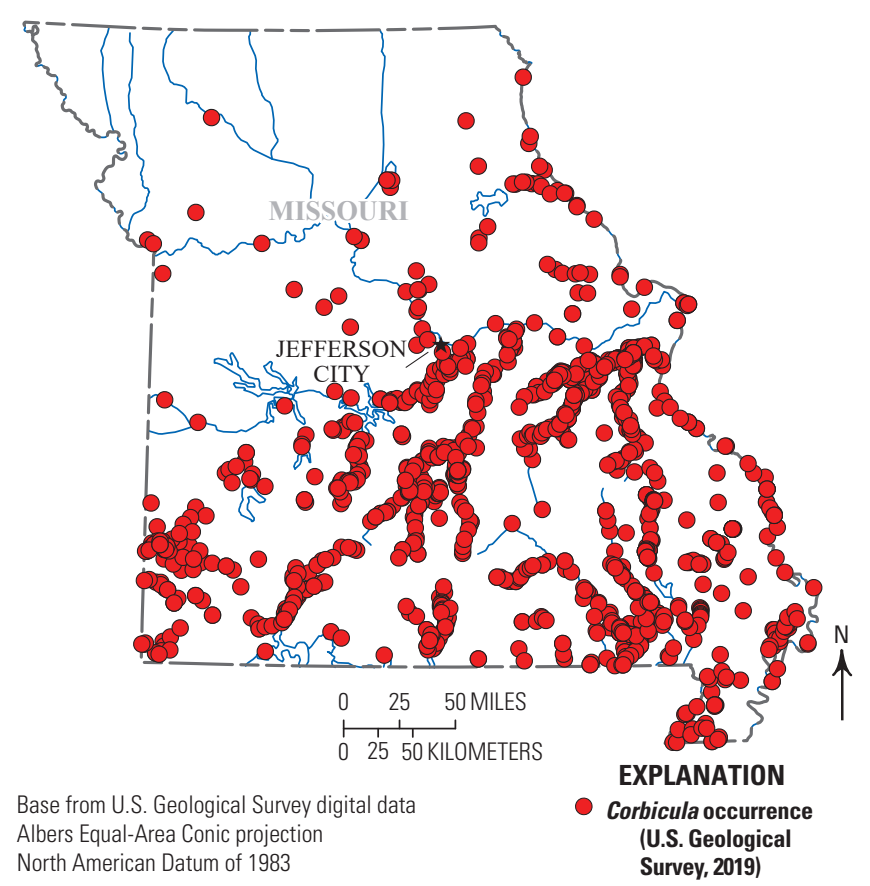

Figure 38. Corbicula spp. occurrences in Missouri through 2019.

Black, Osage Fork (USAO 6630), Pomme de Terre, Sac, Salt, South Fork Blackwater, South Fork Salt, South Prong Little Black, Spring, West Fork Cuivre, West Fork, and Woods Fork (INHS 24097). Corbicula occurrences were also reported from the following 40 creeks for the first time: Beaver (NCSM 55813), Blackberry, Buffalo, Cedar (NCSM 55815), Center, Coon, Courtois, Crane, Crooked, Dry, Duval, Flat, Fox, Grindstone, Hinkson, Hogles, Horse, Indian, Lindley, Little Piney (INHS 24212), Marble, McKenzie, Mill, Muddy, North Moreau, North Prong Beaverdam, Perche, Pettis, Plattin, Roubidoux, Shoal, Spring, Stevenson Bayou, Swan, Turnback, West Fork Fourche, Wet Glaize (NCSM 45030), Whetstone, White Oak, and Wilson. The following lakes and reservoirs with occurrences are Binder, Clearwater, Henry Sever, Hunnewell, Perry County Community Lake, and Stockton. Corbicula largillierti was first reported from the Mississippi (INHS 43819) and Missouri (INHS 43837) Rivers in Missouri in 2012 and Corbicula sp. Form D from the Mississippi River in 2017 (INHS 88540: Douglass and others, 2020). On the basis of this review, Corbicula has been found in 48 of 65 HUC 8 subbasins and 85 of 114 counties in Missouri (figs. 3, 5 , 6 , and 38).

\section{Nevada}

The earliest report of Corbicula in Nevada was by Ingram (1959), who mentioned its presence in the Colorado River, specifically Lake Mead, but did not specify a year. Unfortunately, we were unable to find museum voucher specimens or reports confirming its early presence. Anecdotal information is provided in Fitch (1953): from the San Joaquin River near Sacramento, California, "hundreds of fishermen make weekly treks to Lake Mead, Lake Havasu, and Parker Lake ...," where they would empty their bait buckets [of minnows] with Sacramento River water, likely releasing Corbicula larvae into the Colorado River. Counts (1991) listed only two collections in the State through 1984, both from Lake Mead in 1976 (TCU 3000, 3005). We found one report for an additional waterbody stating that Corbicula was present in the Truckee River as early as 1981, when the river was surveyed by the Pyramid Lake Paiute Tribe (S. Hackley, University of California-Davis, written commun., 2008).

After 1984, there were few waterbodies with occurrence reports of Corbicula in the State. However, this did not translate to the lack of individuals present. In a large lakewide invertebrate study performed in Lake Mead in 1986-87 by Peck and others (1987), they found Corbicula to be dominant in both numbers and biomass. It was found in low numbers at 143 meters (m) in depth, the deepest site sampled in Lake Mead, and the highest density, 1,330 individuals per square meter, was measured at $45 \mathrm{~m}$ in depth (Peck and others, 1987). To further confirm its presence in the Truckee River following an early report, Corbicula was collected from the river near the town of Clark in 1994 (Lawrence and Seiler, 2002). The Truckee River flows north out of Lake Tahoe where in 2002, the first specimens were discovered in the southeastern portion of the lake at low densities, and by 2010 , densities increased dramatically to more than 10,000 individuals per square meter (Wittmann and others, 2012b). Lake Tahoe is the highest elevation waterbody in North America with a Corbicula

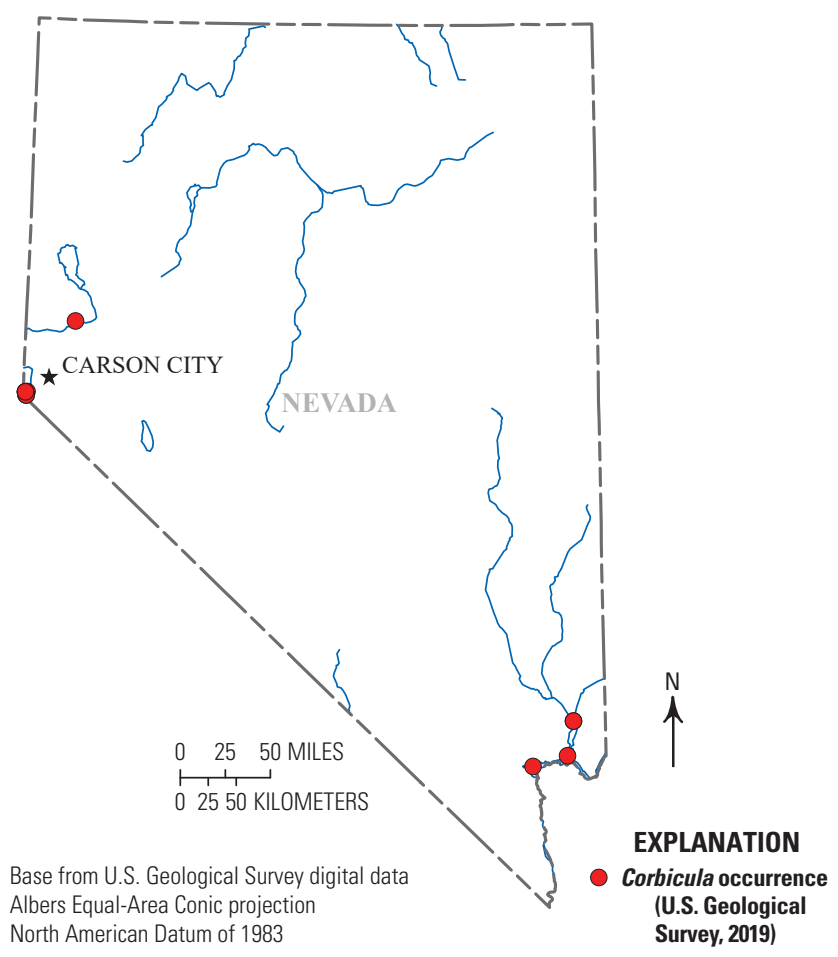

Figure 39. Corbicula spp. occurrences in Nevada through 2019. 
population (Denton and others, 2012). On the basis of this review, Corbicula has been found in 3 of 71 HUC8 subbasins and 3 of 16 counties in Nevada (figs. 3, 5, 6, and 39).

\section{New Jersey}

The earliest collection of Corbicula in New Jersey was made in 1963 from the Navesink River near Red Bank (AMNH 243006), representing the first record in an Atlantic Coast drainage. Counts (1991) listed only the Delaware and Raritan Rivers as collection locations through 1984, with collections made from 1971 to 1981 . We also found an early survey record from the State that reported a population in the Millstone River in 1984. After 1984, Corbicula were found at many locations for the first time in 45 additional waterbodies: Almonesson Creek, Ambrose Brook, Assiscunk Creek, Barton Run, Bear Brook, Blacks Creek, Bound Brook, Chestnut Branch, Cooper River, Crafts Creek, Crosswicks Creek, Doctors Creek, Dukes Brook, Green Brook, Kendles Run (NCSM 30401), Lawrence Brook, Mantua Creek, Maurice River, Mercer County Lake (UF 359843), Middle Brook, Mill Creek (NCSM 30922), Musconetcong River (CMNH 92123), North Branch Big Timber Creek, North Branch Raritan River, Oldmans Creek, Parkers Creek, Passaic River, Peters Brook, Pike Run, Pompton River, Pond Run, Raccoon Creek, Rancocas Creek (ANSP 448590), Royce Brook, Saddle River,

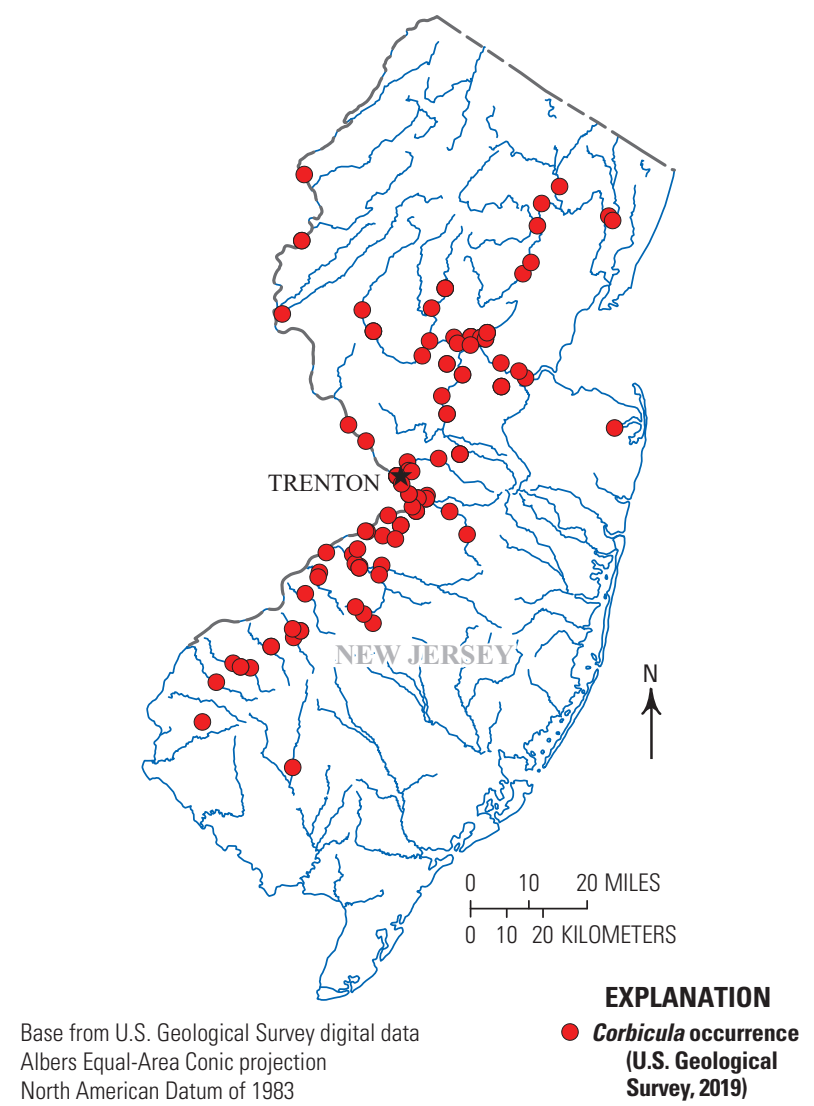

Figure 40. Corbicula spp. occurrences in New Jersey through 2019.
Shabakunk Creek, South Branch Big Timber Creek, South Branch Pennsauken Creek, South Branch Raccoon Creek, South Branch Rancocas Creek, South Branch Raritan River (INHS 19999), Southwest Branch Rancocas Creek, Swedes Run, Tamarack Lake, and Whippany River. On the basis of this review, Corbicula has been found in 7 of 13 HUC8 subbasins and 16 of 21 counties in New Jersey (figs. 3, 5, 6, and 40).

\section{New Mexico}

The first collection of Corbicula in New Mexico was in 1964 from a large man-made drainage ditch adjacent to the Rio Grande River referred to as the "West Drain" located between El Paso, Texas, and Hatch, New Mexico (Metcalf, 1966). Other early collection locations listed in Counts (1991) include the Rio Grande and Pecos Rivers in 1970 and 1973, respectively. We found two collections made prior to 1985 from additional waterbodies not included in Counts (1991): Ute Reservoir on the Canadian River in 1980 (DMNH 136373) and Upper Sabinal Riverside Drain in Belen in 1984. Overall, reports of Corbicula collections and observations in the State have been very limited. After 1984, additional waterbodies with collections for the first time include Alamo Drain, Black River (INHS 16109), Canadian River at Conchas Lake (NCSM 55780), Delaware Creek (UCM 34353), Socorro Main irrigation canal and Rio Grande from Albuquerque to the border with Mexico by 2001. The majority of collection locations have been in the State's largest basin, the Rio Grande, whereas only two collections have been reported in the Canadian River Basin in the Arkansas River drainage. On the basis of this review, Corbicula has been found in 10 of 85 HUC 8 subbasins and 9 of 33 counties in New Mexico (figs. 3, 5, 6, and 41).

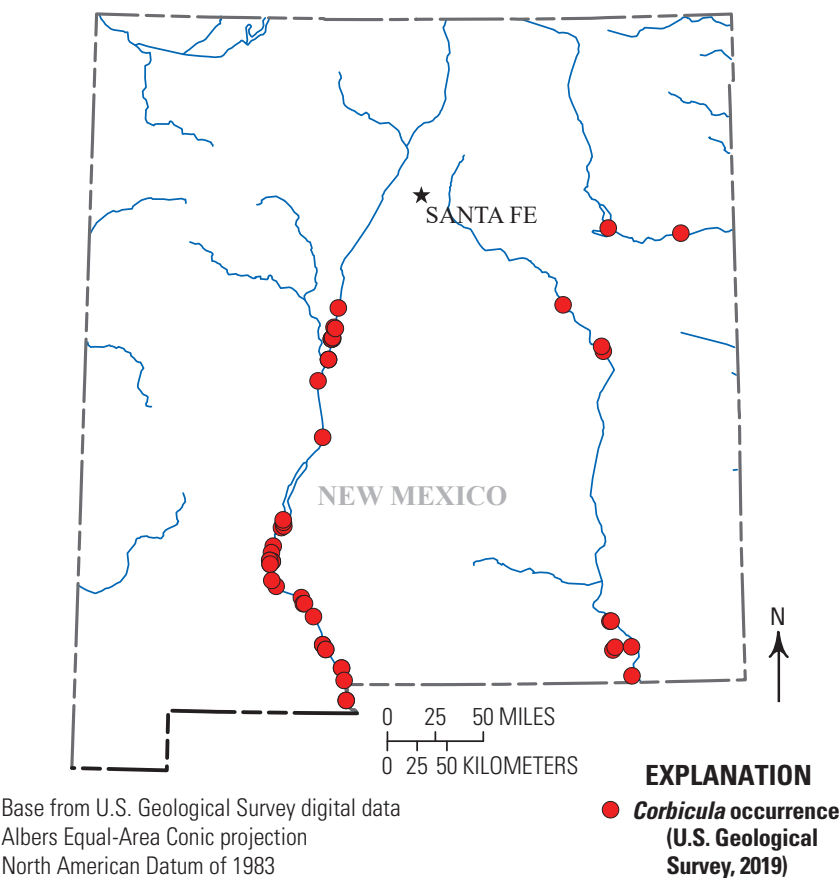

Figure 41. Corbicula spp. occurrences in New Mexico through 2019 . 


\section{New York}

The earliest record of Corbicula in New York is from 1977 at Massapequa Lake along the southern coast of Long Island and was based on an observation by an avid shell collector (Foehrenbach and Raeihle, 1984). The location of that observation was undocumented until 1983, when State biologists discovered a viable population in the lake (AMNH 309366: Foehrenbach and Raeihle, 1984). Counts (1991) listed no other records for Corbicula, nor did we find additional collections made prior to 1985 for the State.

After 1984, Corbicula was collected in 1986 from Tackapausha Lake (AMNH 309365), just west of Massapequa Lake. It was not until the mid-1990s that reports of Corbicula began to increase significantly, beginning in the upper

Susquehanna River drainage of southern New York. In 1999, a collection was made from Seneca Lake, the first for the Finger Lakes region of central New York. Corbicula collections made after 1984 are from the following 24 additional waterbodies: Canandaigua Lake, Carlls River, Castle Creek, Catatonk Creek, Champlain Canal, Chautauqua Lake, Chenango River, Erie Canal, Keuka Lake, Lake Erie, Lake George, Massapequa Creek, Mud Creek, Nissequogue River, Onondaga Lake, Otisco Lake, Otselic River, Owasco Lake, Ramapo River, Schenevus Creek, Susquehanna River, Tioga River, Troublesome Brook, and Unadilla River. The earliest report

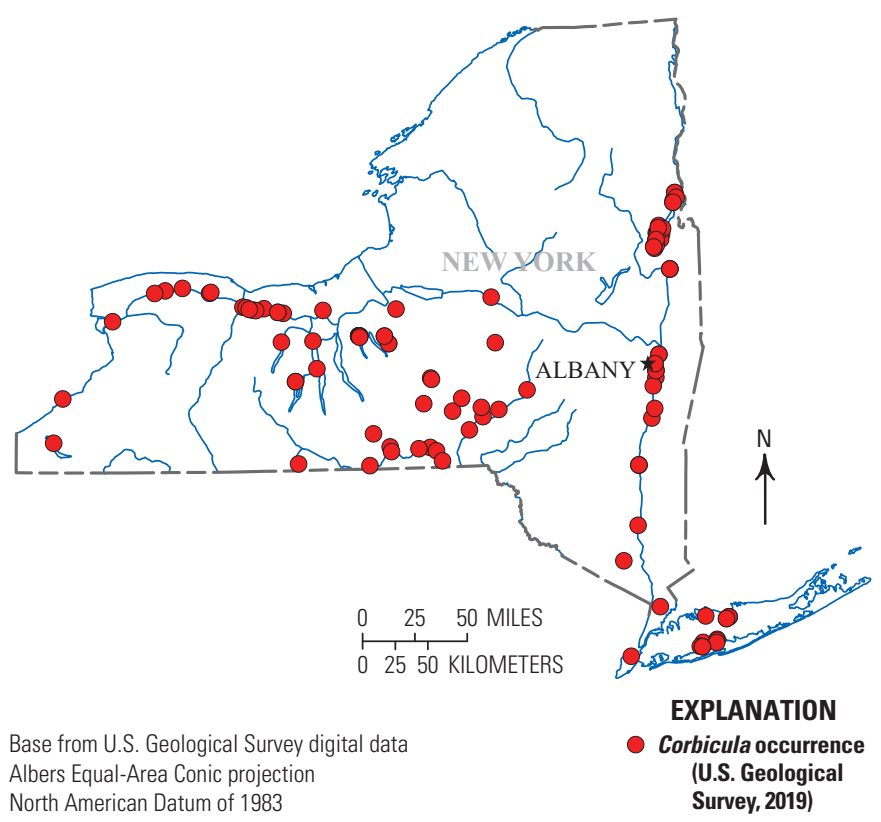

Figure 42. Corbicula spp. occurrences in New York through 2019. from the Hudson River was in 2008 near Kingston. In 2010, a population was discovered in Lake George, a 52-km-long lake in the Adirondack Mountains. At the time of the discovery, Corbicula was believed to be very limited in its distribution in the lake, but within several years the distribution spanned the length of the lake. An eradication of the Lake George population was attempted in 2011 but was unsuccessful (see section "Discussion"). On the basis of this review, Corbicula has been found in 20 of 53 HUC 8 subbasins and 32 of 62 counties in New York (figs. 3, 5, 6, and 42).

\section{North Carolina}

Corbicula was first reported in North Carolina in 1969 by biologists at a Charlotte area power station located at Lake Wylie, a reservoir on the Catawba River (McLeod and Sailstad, 1980). The next reported collection occurred in 1971 from the Pee Dee River (NCSM 55807). By the mid-1980s, Corbicula had dispersed into the following 10 rivers, Cape Fear, Chowan, Little, Meherrin, Neuse, Roanoke, Rocky, Tar, Uwharrie, and Waccamaw, as well as Lake Waccamaw and Buckhorn and Richardson Creeks (see Counts, 1991). We found the following additional waterbodies with Corbicula collections prior to 1985 not included in Counts (1991): Country Line Creek, Dan River, Fishing Creek, Haw River (LACM 1982-10.6), Pee Dee River (NCSM 55807), Smith Creek, and Upper Barton Creek (NCSM 32797).

After 1984, Corbicula was found for the first time in 60 additional rivers: Ararat, Black, Blackwater, Broad, Cane, Cashie, Davidson, Deep, East Fork Deep, East Fork Eno, Eno, First Broad, Flat, French Broad, Green, Henry Fork, Hiwassee, Hyco, Johns, Linville, Little Tennessee, Lower Little, Lumber, Mayo, Middle, Middle Fork South Fork New, Middle Little, Mills, New, Nolichucky, North Flat, North Fork Catawba, North Fork Little, North Fork New, North Fork Tar, North Toe, Northeast Cape Fear, Perquimans, Pigeon, Pungo, Reddies, Roaring, Second Broad, Smith, South Flat, South Fork Catawba, South Fork Little, South Fork New, South Toe, South Yadkin, Swannanoa, Trent, Tuckasegee, Upper Little, Valley, Watauga, West Fork Little, West Branch Rocky, Wiccacon, and Yadkin. Corbicula has also been found statewide for the first time in an additional 396 named and 14 unnamed creeks since 1984, too numerous to list herein (USGS, 2019). On the basis of this review, Corbicula has been found in 45 of 58 HUC 8 subbasins and 90 of 100 counties in North Carolina (figs. 3, 5, 6, and 43). 


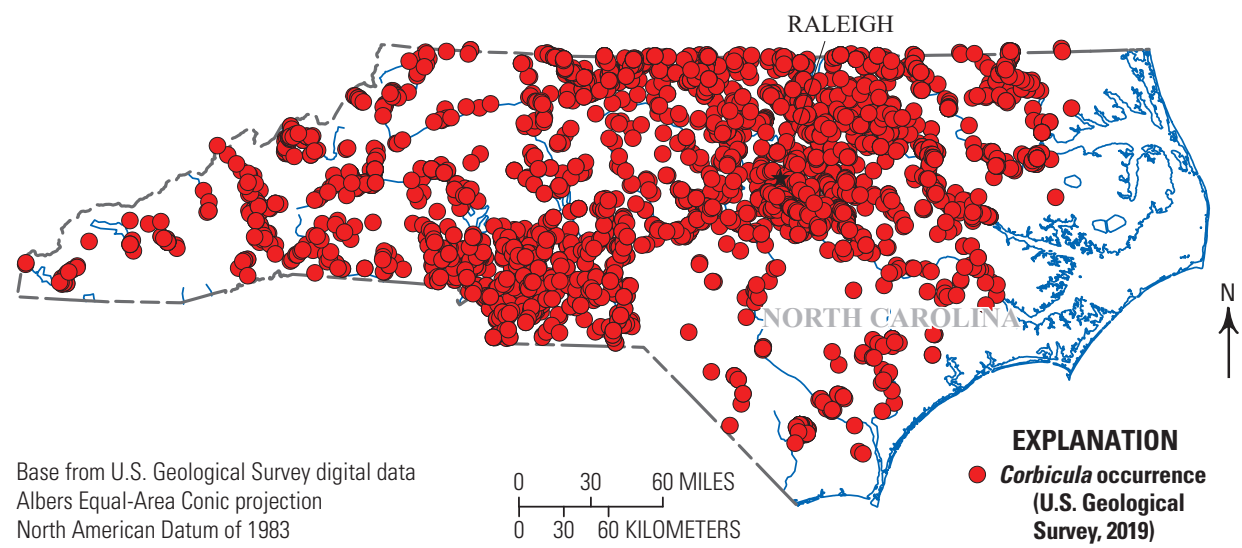

Figure 43. Corbicula spp. occurrences in North Carolina through 2019.

Ohio

Corbicula was first reported in Ohio in 1962 from the Ohio River near Cincinnati (Keup and others, 1963). In 1966, Corbicula was found significantly farther upriver at the mouth of the Muskingum River in Marietta. By the early 1970s, Corbicula began showing up in central Ohio in the Olentangy River (OSUM 27625) north of Columbus. An additional 14 waterbodies with occurrences are included in Counts (1991): Brush Creek, Great Miami River, Hocking River, Jay Lake, Lake Erie, Licking River, Little Muskingum River, Maumee River, Meigs Creek, Muskingum River, Olentangy River, Olive Green Creek, Scioto River, and Stillwater River. From 1981 to 1982, Corbicula was found in several water treatment and powerplant thermal effluent plumes in the Maumee River and Maumee Bay (Lake Erie drainage) in Toledo (Scott-Wasilk and others, 1986). However, the focus of that study was to survey industrial facilities and therefore did not mention if Corbicula was found outside the thermal discharges in the area. We found collections from additional waterbodies made prior to 1985 not included in Counts (1991): Clear Fork Mohican River (OSUM 52851), East Branch Shade River (OSUM 397), and North Fork Licking River (OSUM 26860).

After 1984, collections of Corbicula were made for the first time in the following 11 Ohio rivers: Cuyahoga (OSUM 69287), East Fork Little Miami (OSUM 30794), Lake Fork Mohican (OSUM 66727), Little Miami (OSUM 60163), Little Scioto (OSUM 59385), North Fork Little Miami (OSUM 60411), Sandusky (NCSM 55636), Shade (OSUM 59169), Tuscarawas (OSUM 58942), Walhonding (OSUM 60058), and West Branch Shade (OSUM 65595). Corbicula was also found after 1984 for the first time in the following 42 additional Ohio creeks: Alum (OSUM 56961), Big Darby (OSUM 31522), Big Walnut (OSUM 30951), Black Fork (OSUM 59345), Blacklick (OSUM 31674), Caesar (OSUM 60415), Captina (OSUM 61019), Compton (OSUM 61437), Cowan (OSUM 66169), Crane, Davis (OSUM 32305), Deer (OSUM 58791), Eagle (OSUM 59491), Federal (OSUM 59236), Hales (OSUM 61365), Indian Fork (OSUM 63272), Indian Guyan (OSUM 59268), Leading (OSUM 55997), Little Darby (OSUM 29036), Little Salt (OSUM 65242), Mill (OSUM 69964),
Nettle (OSUM 29311), Ohio Brush Creek (NCSM 55736), Paint (OSUM 58236), Pine (OSUM 29723), Raccoon (OSUM 29724), Rocky Fork (OSUM 59075), Salt (OSUM 65091), Salt Fork (OSUM 55244), Sandy (OSUM 61585), Scioto Brush (OSUM 59513), Seneca Fork Wills (OSUM 61483), Storms (OSUM 65122), Symmes (OSUM 59266), Todd Fork (OSUM 60459), Turkey (OSUM 66548), Walnut (OSUM 32399), West Fork Ohio Brush (OSUM 65374), White Oak (OSUM 59556), Wills (OSUM 59151), Yellow (OSUM 61028), and Yellowbud (OSUM 58859). Corbicula sp. Form D was collected from the Ohio River near Cincinnati in 2016 (INHS 89764) (Douglass and others, 2020). On the basis of this review, Corbicula has been found in 29 of 43 HUC8 subbasins and 46 of 88 counties in Ohio (figs. 3, 5, 6, and 44).

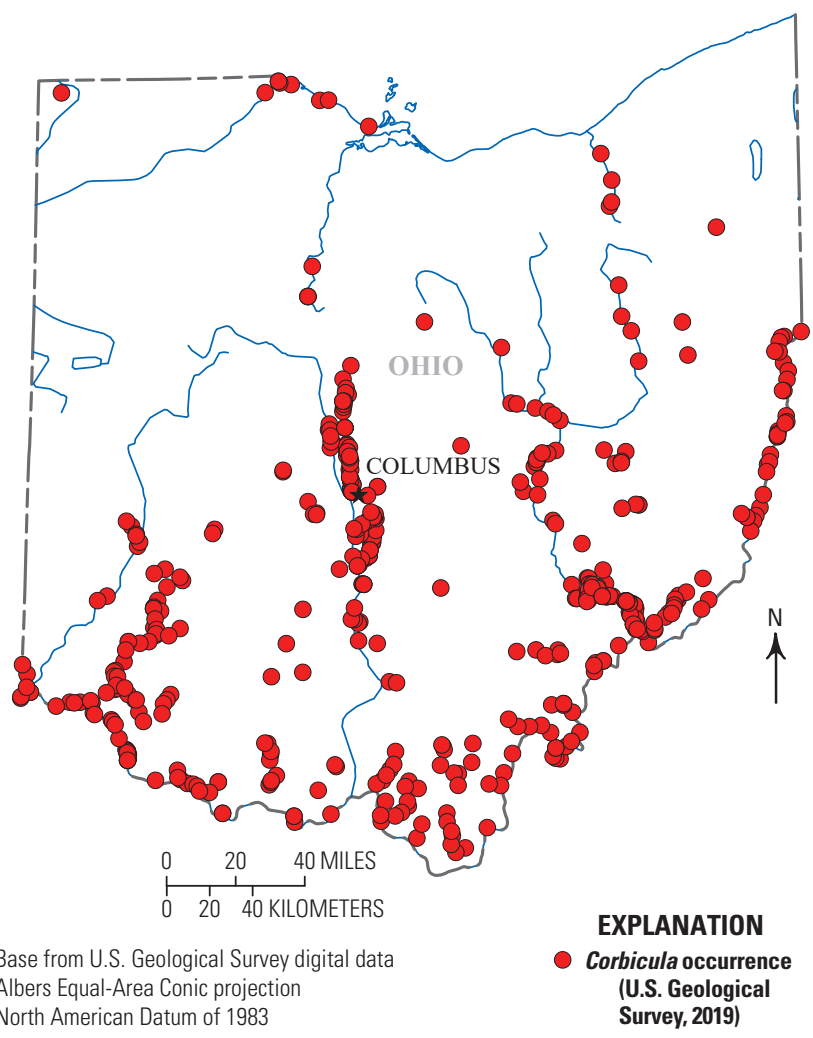

Figure 44. Corbicula spp. occurrences in Ohio through 2019. 


\section{Oklahoma}

The first collection of Corbicula in Oklahoma was made in 1969 from the North Canadian River at Lake Overholser in Oklahoma City (OSUM 35789: Clench, 1972). Counts (1991) listed other early collection locations spread across the State during the late 1970s and early 1980s including the Arkansas, Little, North Canadian, and Red (Lake Texoma) Rivers and Buncombe and Caddo Creeks. We found collections made prior to 1985 from nine additional waterbodies not included in Counts (1991): Blue (USAO 1203), Canadian (Lake Thunderbird) (USAO 1667), Chickaskia (USAO 2965), Illinois (USAO 2972), Kiamichi (Hugo Lake) (USAO 2378), Neosho (Fort Gibson Lake) (USAO 3700), Poteau (USAO 651), Verdigris (NCSM 44416), and Washita (USAO 117) Rivers. Additional waterbodies not included in Counts (1991) where collections were made prior to 1985 include Gates (Lake Raymond Gary) (USAO 3120), Hickory (Lake Murray) (USAO 393), Little Glasses (USAO 1369), Polecat (Lake Heyburn Lake) (USAO 2377), and Stillwater (Lake Carl Blackwell) (USAO 153).

After 1984, Corbicula was collected for the first time from five additional rivers: Caney (Hulah Lake) (USAO 5888), Cimarron (USAO 7943), Deep Fork (USAO 6537), Glover (USAO 5455), and Mountain Fork (USAO 4441). Collections from 30 additional creeks, with reservoir names included, have been reported across the State with exception of the panhandle region to include Anadarche (USAO 7530), Beaver (Waurika Lake) (USAO 3127), Bird (USAO 6506), Black Bear (Lake Fuqua) (USAO 4331), Bluff (Lake Hefner) (USAO 7491), Carr (USAO 6673), Chandler (Lake Ellsworth) (USAO 8892), Cobb (USAO 2891), Cow (USAO 7589), East Bills (Lake Louis Burtschi) (USAO 3562), East Cache (USAO 7811), Fourteenmile (USAO 7318), Greasy (Sooner Lake), Guy Sandy (USAO 8031), Hickory (INHS 14178), Jack Fork (USAO 8607), Jumper (Lake Konawa) (USAO 4097), Lee, Little Greenleaf (USAO 6663), Lukfata (USAO 6766), Mud (USAO 6742), Muddy Boggy (USAO 7855), North Stillwater (Lake McMurtry) (USAO 5023), Pennington (USAO 4349), Rock (Lake of the Arbuckles) (USAO 7562), Sallisaw (NCSM 44467), West Otter (Tom Steed Reservoir) (USAO 5502), Wildhorse (Lake Humphreys) (USAO 7164), Wolf (Fort Supply Lake) (USAO 4374), and an unnamed creek (American Horse Lake) (USAO 6098). Additional lakes and reservoirs with Corbicula collections for the first time include Grand Lake O' the Cherokees (USAO 7851), Guthrie Lake (USAO 7910), Lake Hudson (USAO 7852), Lake Yahola (NCSM 44461), and Liberty Lake (USAO 7563). On the basis of this review, Corbicula has been found in 42 of 68 HUC8 subbasins and 51 of 77 counties in Oklahoma (figs. 3, 5, 6, and 45).

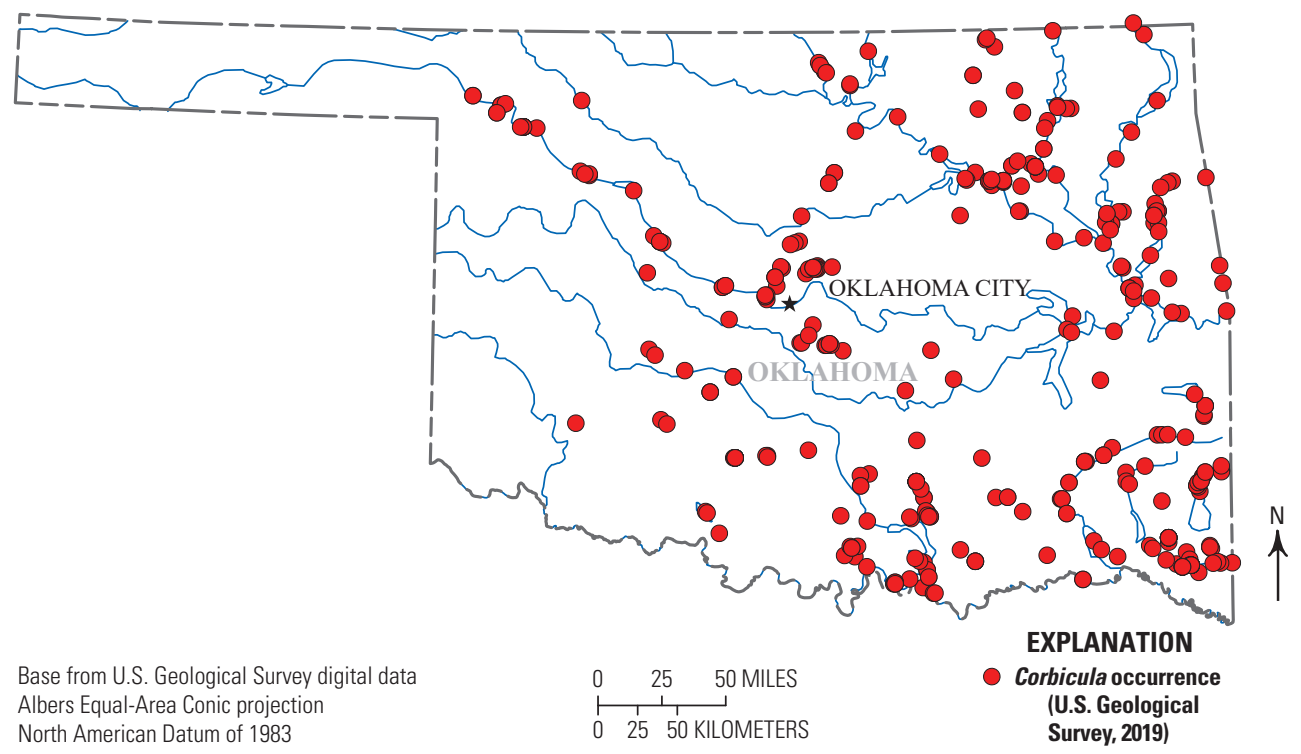

Figure 45. Corbicula spp. occurrences in Oklahoma through 2019. 


\section{Oregon}

The first occurrence of Corbicula in Oregon was in 1943 from the Columbia River near Portland (Fox, 1971a). The earliest museum voucher specimen was collected in 1946 from the Columbia River near Astoria (NCSM 48750). Counts (1991) listed collections made from 1950 to 1981 from the Columbia, John Day, Siuslaw, Smith, and Willamette Rivers. We found two collections made prior to 1985 from additional waterbodies not included in Counts (1991): Jordan Creek (MMNS 11934) and Sprague River (MMNS 11935), both in 1981 .

Corbicula was collected after 1984 for the first time from an additional 16 rivers: Clackamas, Clatskanie, Clearwater, Coast Fork Willamette, Coos, Coquille, Deschutes (Lake Billy Chinook), Lewis and Clark, Long Tom (Fern Ridge Lake), Marys, Rogue, Smith, Snake (NCSM 55787), South Umpqua, Umpqua (INHS 22291), and Youngs. An additional 10 creeks and lakes have been found with first-time Corbicula occurrences after 1984: Brush, Burgett, Catching Slough, Lower Coyote (Fern Ridge Lake), Marsh Island, Murderers, Scholfield, and Spencer Creeks and Eel Lake (INHS 22292) and Sturgeon Lake. As part of an invasive species early detection program for Dreissena spp. in the Columbia River Basin, Corbicula veligers were identified in four stretches of the Columbia River in the State (Bonneville, The Dalles, John Day, and McNary) and for the first time in Lake Billy Chinook and Fern Ridge Reservoir in the Deschutes and Willamette River Basins, respectively (Hassett and others, 2017). Reports

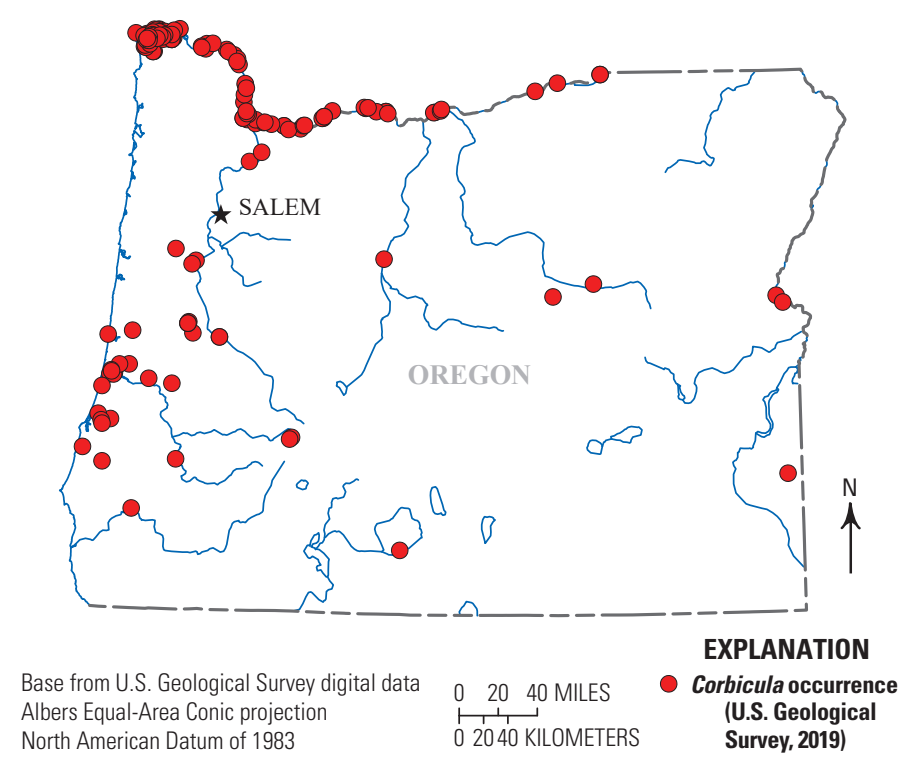

Figure 46. Corbicula spp. occurrences in Oregon through 2019. of collection locations since 1984 have been relatively sparse given Corbicula's early arrival in the State. On the basis of this review, Corbicula has been found in 22 of 92 HUC8 subbasins and 19 of 36 counties in Oregon (figs. 3, 5, 6, and 46).

\section{Pennsylvania}

The earliest reported collection of Corbicula in Pennsylvania was in 1972 from the Delaware River near Philadelphia (Fuller and Powell, 1973). Through 1984, occurrence locations were limited to waters surrounding the cities of Pittsburgh and Philadelphia and included only four other waterbodies in the State: Beaver, Monongahela, Ohio, and Schuylkill Rivers (see Counts, 1991). We found two collections made prior to 1985 from additional waterbodies not included in Counts (1991): Allegheny River in 1983 (OSUM 54646) and Dunkard Creek in 1981 (ANSP 391659).

After 1984, there was a significant expansion of Corbicula across the State in all three major river drainages, Delaware, Ohio, and Susquehanna Rivers. The following additional 14 rivers were found to have occurrences of Corbicula for the first time: Allegheny (OSUM 28975), Beaver, Conemaugh, Conestoga, Frankstown Branch Juniata, Juniata, Lehigh, Little Shenango, Raystown Branch Juniata, Shenango, Susquehanna (ANSP A20995), Tioga, West Branch Susquehanna, and Youghiogheny (CMNH 133583). The following 63 creeks and small lakes have been reported with Corbicula occurrences for the first time: Aughwick, Bald Eagle, Bennett Branch Sinnemahoning, Bowman, Brandywine, Brush, Buffalo, Canoe, Chester, Chiques, Clearfield, Codorus, Conewago, Conneaut Lake, Connoquenessing (CMNH 107716), Conodoguinet (OSUM 56504), Conowingo, Crooked, Driftwood Branch Sinnemahoning, East Branch Brandywine, First Fork Sinnemahoning, French (INHS 19610), Jacobs (CMNH 83351), Lake Arthur, Lake Stonycreek, Little Aughwick, Little Brokenstraw, Little Clearfield, Little Neshaminy, Little Swatara, Little Yellow (ANSP 397009), Loyalhanna (CMNH 72879), Loyalsock, Lycoming, Mahoning, Manatawny, McConnell Lake, Middle, Muddy (CMNH 66554), Neshaminy, North Fork Little Beaver, Pennypack (ANSP 401251), Pequea, Perkiomen, Pigeon, Pine (ANSP 394846), Plum (ANSP 397013), Raccoon, Ridley, Sandy (CMNH 141716), Sandy Lake, South Branch Plum, South Fork Tenmile, South Sandy, Struble Lake, Swatara, Tenmile (ANSP 392646), West Branch Brandywine, Wissahickon (ANSP 399348), Woodcock, Yellow (CMNH 144440), Yellow Breeches, and Yellow Creek State Park Lake (ANSP 397011). On the basis of this review, Corbicula has been found in 40 of 52 HUC8 subbasins and 52 of 67 counties in Pennsylvania (figs. 3, 5, 6, and 47). 


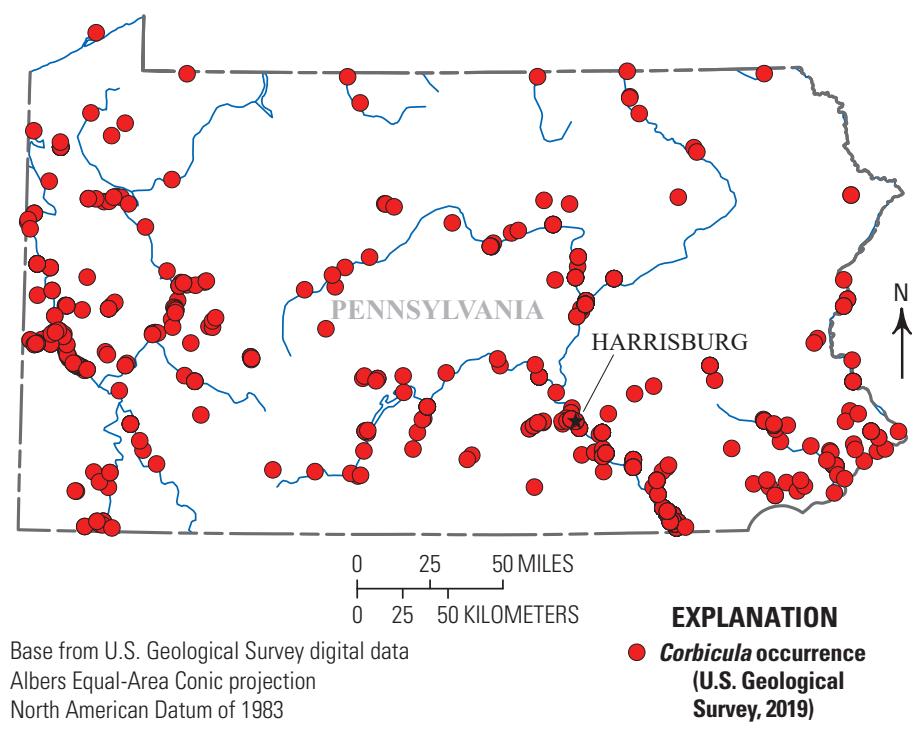

Figure 47. Corbicula spp. occurrences in Pennsylvania through 2019.

\section{South Carolina}

A report by Duke Power Company (1983) stated that Corbicula was present in South Carolina as early as 1968 at Catawba Nuclear Station located on Lake Wylie, a reservoir on the Catawba River. The earliest museum voucher specimen was collected from the West Branch Cooper River at Lake Moultrie in 1972 (USNM 827295) but was not included in Counts (1991). Counts (1991) listed the following 16 waterbodies with Corbicula occurrences: Beaverdam Creek, Broad River (including Parr Shoals Reservoir), Cooper River (including Lake Moultrie), Edisto River, Frees Creek (including Monticello Reservoir), Intracoastal Waterway, Lake Keowee, Little Pee Dee River, Pee Dee River, Salkehatchie River, Saluda River (including Lake Murray), Santee River (including Lake Marion), Savannah River (including Hartwell Reservoir), South Edisto River, Upper Three Runs, and Waccamaw River. We found collections made prior to 1985 from five additional waterbodies not included in Counts (1991): Congaree River (OSUM 44158), East Branch Cooper River (ANSP A17919), Little River (NCSM 32734), North Edisto River (LACM 1981-69.9), and Rocky River.

After 1984, the following additional 17 rivers were reported for the first time with Corbicula occurrences: Ashley, Black, Bush (NCSM 85078), Chauga, Combahee (NCSM 12866), Enoree, Little Lynches (NCSM 48002), Little Saluda, Lumber (NCSM 13650), Lynches (NCSM 21803), Middle Saluda (INHS 21442), Pacolet (INHS 3861), Reedy (NCSM 32656), Sandy, Tyger, Wateree, and West Fork Little. The following 118 creeks, primarily in higher elevation locations, were reported occurrences of Corbicula for the first time: Allison, Bagg, Bear, Beaver, Big (NCSM 32695), Allison (NCSM
32760), Big Cowhead, Big Curltail, Big Dutchman, Big Poplar (NCSM 35197), Big Wateree (NCSM 32779), Brightmans (NCSM 32652), Browns, Bryson, Buffalo, Bull Run, Bullock, Byrd, Camp (NCSM 32744), Camping, Cane (NCSM 32680), Cedar (UF 359800), Cheves, Clark Fork, Clouds, Connor, Coronaca (NCSM 32780), Coxs, Crowders (NCSM 85423), Cuffytown, Cunning Ford, Dry, Duncan, Dutchmans (NCSM 32692), Fairforest, Fishing (NCSM 31966), Flat (NCSM 32758), Gilders, Gills, Grannies Quarter, Gundy, Guyonmoore, Headleys, Hanging Rock, Hannahs, Hard Labor, Hellers, Henley (NCSM 32703), Hollow, Hooper, Horn, Horse, Hunting, Indian, Jacks (UF 359788), Johns, Joshuas Branch, Juniper, Kings, Kinley, Lee, Little Allison, Little Hollow, Little Horse, Little Mountain, Little Rocky (NCSM 32764), Little Stevens, Little Wateree (NCSM 32653), Log, Long Cane, Lott, Manchester, Mill, Millers Fork, Mine, Moores, Mountain, Mud, Ninety Six (NCSM 32771), North Branch Wildcat, Padgetts, Rabon (NCSM 32769), Rawls, Reaves, Red Bank, Rice, Rocky (NCSM 32650), Rocky Branch, Sawneys, Scott, Shaw, Sixmile (NCSM 32651), Sleepy, South Fork Duncan, South Fork Fishing (NCSM 32683), South Prong Camp, Steele (NCSM 31964), Stevens (INHS 22149), Stony Fork (NCSM 32681), Subers, Sugar (NCSM 31967), Taylor (NCSM 32750), Thompson (NCSM 32746), Timothy, Tinkers (NCSM 32786), Turkey (NCSM 27907), Twelvemile (NCSM 32657), Twentyfive Mile, Warrior, Wateree, Waxhaw (NCSM 31969), West, Westfield (NCSM 32694), White, Wildcat, and Wilson. On the basis of this review, Corbicula has been found in 29 of 38 HUC8 subbasins and 41 of 46 counties in South Carolina (figs. 3, 5, 6, and 48).

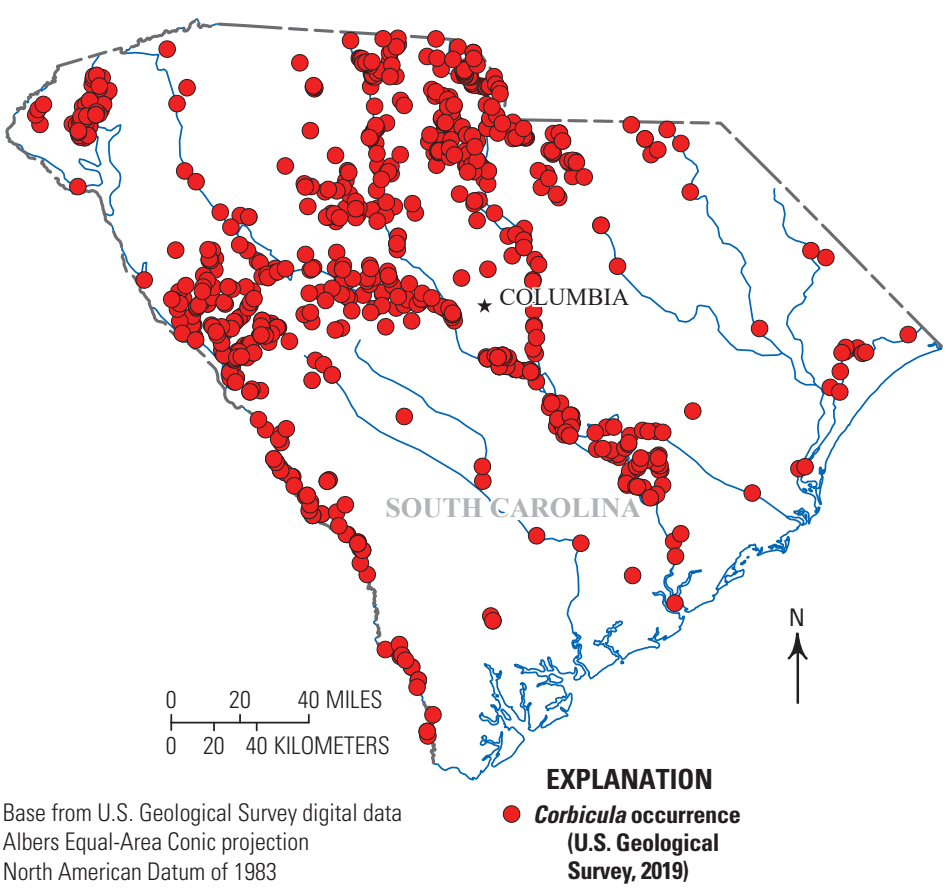

Figure 48. Corbicula spp. occurrences in South Carolina through 2019. 


\section{Tennessee}

The first collection of Corbicula in Tennessee was in 1959 from the Tennessee River just below Pickwick Dam (Sinclair and Ingram, 1961). In the 10 years following that discovery, Corbicula was found at a number of locations along the entire length of the Tennessee River within the State. By 1984, it was found in 52 waterbodies across the State which include Barren Fork, Buffalo, Clinch, Collins, Cumberland, Duck, East Fork Stones, Elk, Garrison Fork, Harpeth, Hatchie, Little, Little Duck, Little Emory, Little Tennessee, Mississippi, Nolichucky, North Fork Holston, Obey, Piney, Red, Sequatchie, South Fork Holston, Stones, West Fork Stones, Tellico, and Tennessee Rivers and Bear, Big Bigby, Big Rock, Big Swan, East Rock, Fall, Flat, Fountain, Grassy, Hickory, Leipers, Lick, Little Flat, Ninemile, North Fork, Notchy, Rich, Richland, Rutherford, Shoal, Sinking, South Chickamauga, Spring, Sugar, and Weakly Creeks (see Counts, 1991). In addition, we found museum voucher collections made prior to 1985 for three rivers that were not included in Counts (1991): Conasauga (MMNS 11696), Hiwassee (ANSP A11441B), and Holston (ANSP A4981). The following 24 creeks were also found to have Corbicula occurrences prior to 1985 but were not included in Counts (1991): Bledsoe (UT 7814), Candies (NCSM 55784), Caney (ANSP A4243), Chestuee (NCSM 55638), Coahulla (NCSM 55631), Crow (NCSM 55802), Decatur (NCSM 55750), East Rock (OSUM 41552), Ewing (OSUM 48034), Goodfield (NCSM 55644), Gunstocker (NCSM 55647), Horse (NCSM 55685), Little Bigby (OSUM 54502), Little Chucky (ANSP A11968), Rogers
(NCSM 55747), Sewee (NCSM 55746), Shipman (ANSP 334407), Silver (OSUM 39581), Soddy (NCSM 55660), Thompson (OSUM 40903), Wartrace (OSUM 52908), Whites (NCSM 55697), Wilson (OSUM 40896), and Wolftever (NCSM 55726).

After 1984, the following 12 rivers were reported with occurrences of Corbicula for the first time: Big South Fork Cumberland (INHS 16355), Calfkiller (CMNH 90993), Caney Fork (CMNH 131528), Falling Water (CMNH 105306), Little Buffalo (INHS 13988), Little Pigeon (UT 5340), New (NCSM 84383), Pigeon (UT 5416), Powell (NCSM 32001), West Fork Obey (NCSM 55651), West Prong Little Pigeon (ANSP 372647), and Wolf (UT 5333). The following 27 creeks have reported occurrences of Corbicula for the first time: Alexander (INHS 3345), Beech Log (INHS 9682), Bent (NCSM 35111), Big, Big Limestone (NCSM 100806), Big Sewee (NCSM 29752), Big Sycamore, Big War, Blackwater, Cane (OSUM 32241), Citico (NCSM 55753), Conasauga (NCSM 55664), Crooked (NCSM 29464), Dunn (NCSM 29923), Fisher (NCSM 35159), Greasy (NCSM 55801), Indian (NCSM 35158), Little Wolftever (NCSM 55649), Mill (NCSM 55640), Panther, Pond (NCSM 29703), Short (NCSM 29711), Steekee (NCSM 29753), Swan (CMNH 92130), Tenmile (NCSM 55665), West Fork Hickory (INHS 6535), and Whitehorn (NCSM 30671). Corbicula sp. Form D was collected from the Tennessee River at Kentucky Lake in 2018 (INHS 89548) (Douglass and others, 2020). On the basis of this review, Corbicula has been found in 40 of 55 HUC8 subbasins and 67 of 95 counties in Tennessee (figs. 3, 5, 6, and 49).

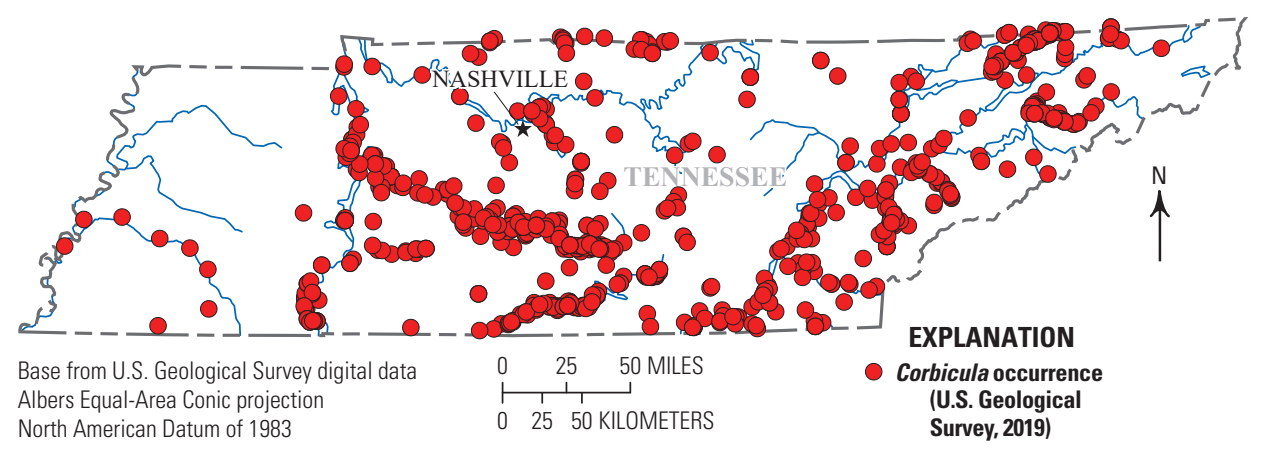

Figure 49. Corbicula spp. occurrences in Tennessee through 2019. 
Texas

The earliest collection of Corbicula in Texas was in 1958 from B.A. Steinhagen Lake, a reservoir on the Neches River north of Beaumont in the eastern portion of the State (HMNS.MAL 033672) (Howells and others, 2004). Six years later, a collection was made in western Texas in 1964 from the Rio Grande near El Paso (HMNS.MAL 035549). By the early 1970s, Corbicula was found at numerous locations across the State. Counts (1991) listed the following 25 rivers with Corbicula collections through 1984: Angelina, Atascosa, Blanco, Brazos, Clear Fork Trinity, Colorado, Concho, Frio, Guadalupe, Leon, Little Brazos, Llano, Medina, Middle Concho, Nueces, Pecos, Pedernales, Red, Rio Grande, Sabine, San Antonio, San Gabriel, San Jacinto, West Fork Trinity, and White. Counts (1991) also included creeks in the State with Corbicula occurrences: Big Boggy, Big Cypress, Denton, Geronimo, Johnson, Pinto, Spring, and Wilson. We found Corbicula collections made prior to 1985 from seven additional waterbodies not included in Counts (1991): Devils River, Lampasas River (USAO 1467), Little Cypress Bayou (USAO 3043), Murvaul Creek, Navasota River (USAO 2735), Pecan Bayou, and Pinto Creek (USNM 1152353).

After 1984, Corbicula was found for the first time in 23 additional rivers: Attoyac, Comal, Devils, East Fork San Jacinto (INHS 7652), East Fork Trinity, Elm Fork Trinity (USAO 6788), Lampasas, Lavaca (NCSM 55764), Little Wichita, Middle Concho, Navidad (NCSM 55699), Neches (USAO 7667), North Concho, North Fork Guadalupe, North Fork San Gabriel (UF 281866), Paluxy (OSUM 30540), San Marcos (NCSM 35222), San Saba (USAO 4108), South Concho, Sulphur (USAO 4916), West Fork San Jacinto, West Fork Trinity, and Wichita. The following 64 creeks were found to have Corbicula occurrences for the first time after 1984: Ayish Bayou, Bear (INHS 16194), Beaver, Beitel, Big (NCSM 55642), Big Cow (INHS 3918), Big Pine (USAO 6641), Brady, Buffalo, Buffalo Bayou, Camp, Caney (USAO 6938), Cedar, Champion, Cherokee, Cibolo, Clear (INHS 14164), Cypress, Deer, Dove, Duck, East Sandy, Elm (USAO 7395), Garcitas (NCSM 55700), Gorman, Hickory, Holiday, Hondo, Hords, Hubbard, Hurricane (NCSM 55657), Hutton, Irish, Jones, Bayou La Nana, Las Moras, Long King, Martin (Rusk County) (USAO 6696), Mountain, Mussel Shoals, Oak, Olmos, Onion, Oyster, Pepper, Pine (USAO 6958), Richland, Rocky, Salitrillo, San Miguel, Sanders (USAO 6946), Sandy, Sixmile (NCSM 55656), Squaw, Sulphur, Sutherland (NCSM 55789), Tehuacana, Tradinghouse, Turkey, Turtle, Valley, Village (USAO 3528), White Rock, and Yegua. Although Karatayev and others (2005) compiled records for 162 lotic and 174 lentic waterbodies in the State with Corbicula occurrences, we were not able to locate records for some of these waterbodies. On the basis of this review, Corbicula has been found in 126 of 204 HUC8 subbasins and 156 of 254 counties in Texas (figs. 3, 5, 6, and 50). 


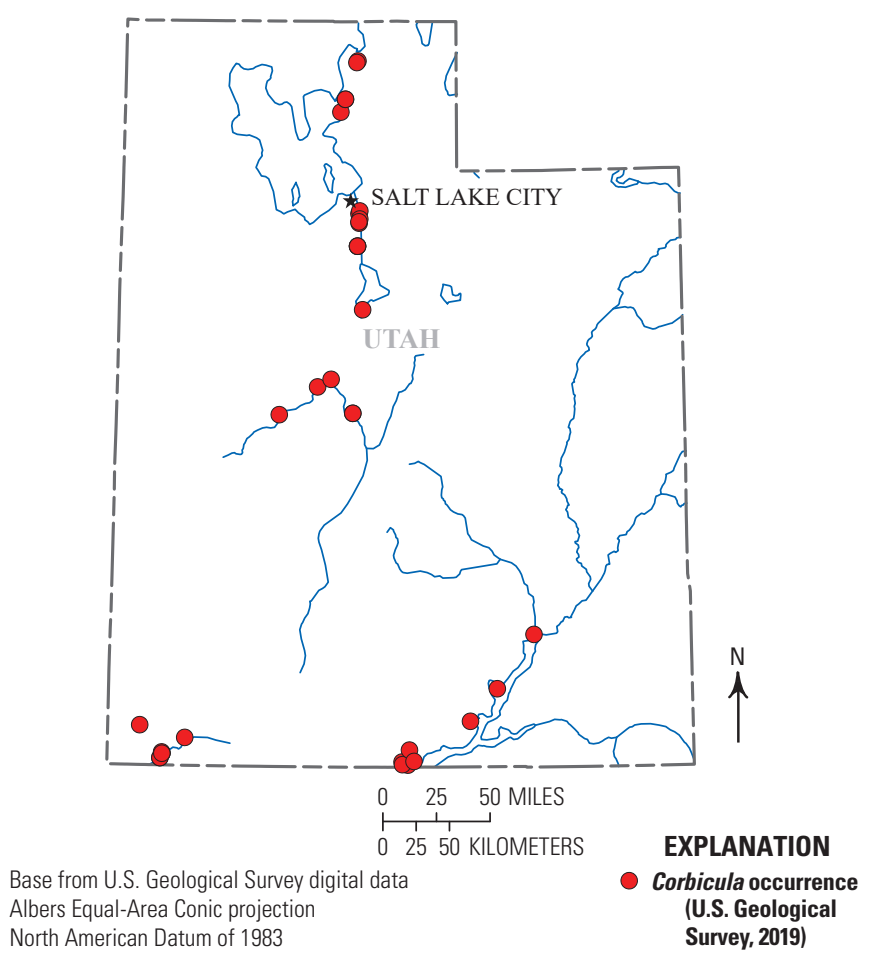

Figure 51. Corbicula spp. occurrences in Utah through 2019.

\section{Virginia}

According to Counts (1991), the earliest collection of Corbicula in Virginia was in 1965 from the Clinch River at North Tazewell (MCZ 268583) in the southwestern part of the State. However, upon examination of specimen photographs, it was reidentified as Sphaerium simile (Say, 1817) (Grooved Fingernailclam). Therefore, the earliest documented Corbicula collections in the State are likely those made in the Atlantic Coast drainage in 1971 from the lower Appomattox River and the lower reach of the James River (Diaz, 1974). The earliest known collection in the Clinch River, a headwater tributary of the Tennessee River, was made in 1975 (ANSP A11265). By 1984, Corbicula was present in the State from the east coast to higher elevations in the west. Counts (1991) listed Corbicula in the following waterbodies: Appomattox, Blackwater, Chickahominy, Clinch, James, New, North Anna, Nottoway, and Potomac Rivers, and Copper Creek. In addition, we found collections made prior to 1985 from the following seven waterbodies not included in Counts (1991): Craig Creek, Mechums River, Middle Fork Holston River, Muddy Creek, North Fork Holston River (UT 3264), Rivanna River, and South Fork Powell River (OSUM 52900).

After 1984, Corbicula dispersed throughout most of the State into an additional 74 rivers including the Banister (NCSM 32799), Big Otter, Bluestone, Buffalo, Bullpasture, Bush, Calfpasture, Cowpasture, Cranes Nest, Dan, Dry, Falling, Guest, Hardware, Hazel (OSUM 31533), Hughes, Hyco, Jackson, Little, Little Calfpasture, Little Nottoway, Matta (NCSM 47157), Mattaponi, Maury, Mechums, Meherrin, Middle, Middle Fork Holston (OSUM 28939), Middle Meherrin, Moormans, Motto, Newfound, Ni, North, North Fork Blackwater, North Fork Clinch, North Fork Hardware, North Fork Holston (OSUM 30596), North Mayo, North Fork Nottoway, North Fork Powell, North Fork Rivanna, North Fork Roanoke, North Fork Shenandoah, North Mayo, North Meherrin, Occoquan, Pedlar, Piankatank, Po, Poropotank, Powell (INHS 9764), Rapidan (OSUM 31811), Rappahannock (OSUM 8916), Rivanna, Roanoke (NCSM 29618), Robinson, Rockfish, Sandy, Shenandoah, Slate, Smith, South, South Anna, South Fork Holston, South Fork Powell, South Fork Rivanna, South Fork Shenandoah, South Meherrin, Stinking, Thornton, Tye, West Fork Little, and Willis. Too numerous to list herein are the 284 additional creeks, runs, and unnamed tributaries where collections have been made and reported for the first time (USGS, 2019). On the basis of this review, Corbicula has been found in 38 of 47 HUC8 subbasins and 108 of 133 counties and independent cities in Virginia (figs. 3, 5, 6, and 52).

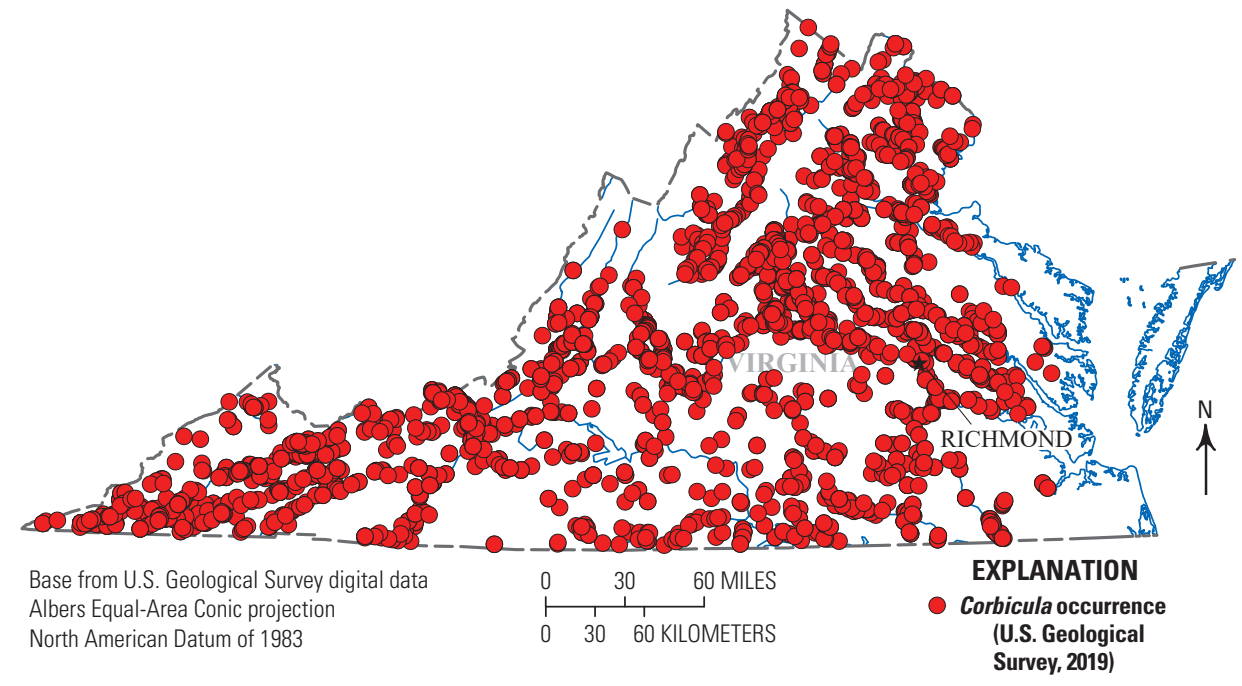

Figure 52. Corbicula spp. occurrences in Virginia through 2019. 


\section{Washington}

The earliest report of Corbicula in the State of Washington was also the earliest in the entire United States, a collection made at Raymond in 1937 (LACM 64359) (Counts, 1985a). Although no waterbody name accompanied this specimen, the town of Raymond is located on the Willapa River, a likely source for the collection. For several decades, the earliest published account of a Corbicula collection in the United States had been based on a 1938 specimen collected from the Columbia River near Knappton, Washington (CAS-IZ 219729: Burch, 1944). By 1952, Corbicula had dispersed across the State as far as the Snake River (USNM 608480) near the Idaho border. Counts (1991) listed only two other waterbodies where collections had been made, Lake Aberdeen and Hood Canal. A collection not included in Counts (1991) was made in 1968 from the mouth of the Palouse River (USNM 903692), a tributary of the Snake River in southeastern Washington.

After 1984, many waterbodies were reported for the first time with Corbicula occurrences. However, some of the reports, beginning after the arrival of Dreissena spp. in the Great Lakes in about 1986, likely represent a new awareness for invasive species and not recent dispersal. As part of an early detection program for Dreissena spp. of mussels in the Columbia River Basin, Corbicula veligers were found in the five main reservoirs on the main stem of the Columbia River, as well as in one reservoir off of the river main stem from 2013 to 2014 (Hassett and others, 2017). From 1998 to 2018, Corbicula was reported for the first time in 26 waterbodies surrounding Puget Sound: Benson Lake, Big Lake, Black Lake, Capitol Lake, Lake Cavanaugh, Clear Lake, Cowlitz River, Deep Lake, Green River, Lake Sawyer, Lake Stevens, Lake Tapps Reservoir, Lake Washington (INHS 22289), Lake Whatcom, Long Lake, Mason Lake, Ohop Lake, Phantom Lake, Lake Sammamish, Skagit River, Spanaway Lake, Summit Lake, Union Lake, Lake Washington Lake Ship Canal, White River, and Williams Lake. Other occurrence locations across the State include an additional 29 waterbodies: Baker River, Blue Lake, Carrolls Channel, Chehalis River, Copper Creek, Curlew Lake, Deep River, Deer Lake, Garrison Creek, Grays Bay, Grays River, Horsethief Lake, Lake Chelan, Lake Wenatchee, North Fork Lewis River, Liberty Lake, Martin Slough, Moses Lake, Newman Lake, Okanogan River, Osoyoos Lake, Ozette Lake, Pend Oreille River, Spokane River, Tieton River, Waitts Lake, Wannacut Lake, Wynoochee River, and Yakima River. Corbicula has been found at locations spanning the lengths of the Columbia, Pend Oreille, Snake, and Spokane Rivers within the State. On

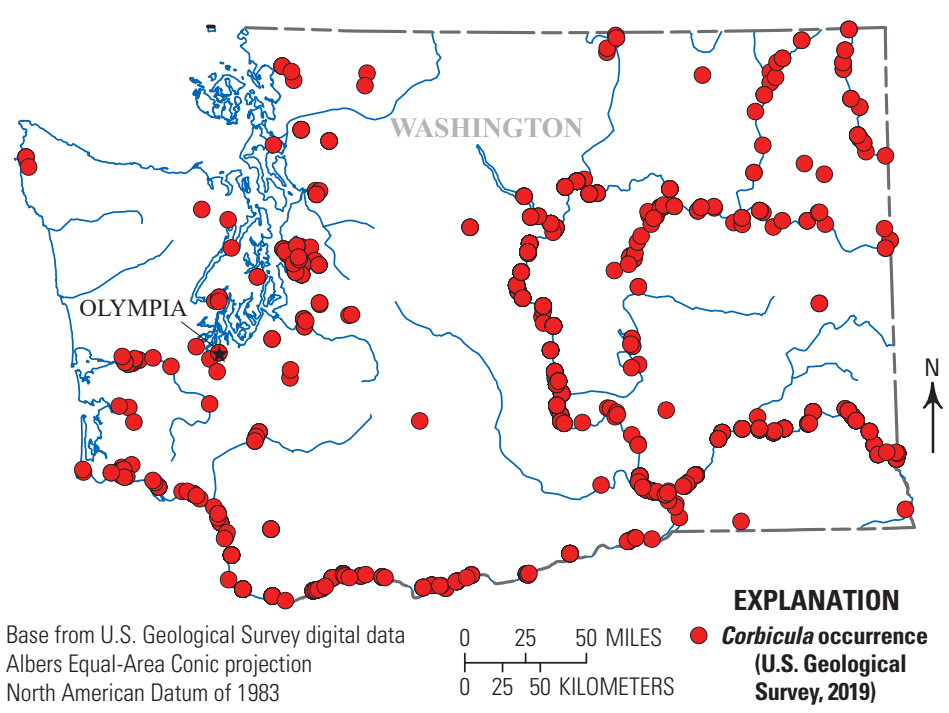

Figure 53. Corbicula spp. occurrences in Washington through 2019.

the basis of this review, Corbicula has been found in 45 of 71 HUC8 subbasins and 37 of 39 counties in Washington (figs. 3 , 5,6 , and 53).

\section{West Virginia}

Corbicula was first reported in West Virginia in 1963 from the Kanawha River, an Ohio River tributary (Thomas and Mackenthun, 1964). This specimen represented a very early collection date relative to the 1957 record from the lower Ohio River, the first appearance of Corbicula in the Mississippi River drainage. As early as 1962, Corbicula was found midway up the Ohio River at Cincinnati, Ohio (Keup and others, 1963). Counts (1991) listed the following 17 additional rivers with Corbicula occurrences: Bluestone, Cacapon, Elk, Greenbrier, Guyandotte, Henry Fork, Little Kanawha, Monongahela, Mud, New, North Fork Little Cacapon, Pocatalico, Potomac, Shenandoah, South Branch Potomac, South Fork Hughes, and West Fork. The following 12 creeks are listed in Counts (1991) where collections have been made: Beech Fork, Sevenmile, Cedar, Indian, Leading, Left Fork Steer, Little Hurricane, Middle Island, Patterson, Spring, Steer, and Twelvepole.

After 1984, 11 additional waterbodies were reported with first-time occurrences of Corbicula: Dunkard Creek, Fishing Creek, Hackers Creek, Isaacs Creek, Kincheloe Creek, Left Fork Reedy Creek, Lost Creek, North Fork Hughes River (INHS 28467), Sleepy Creek, South Mill Creek, and Tenmile Creek. On the basis of this review, Corbicula has been found in 24 of 30 HUC 8 subbasins and 40 of 55 counties in West Virginia (figs. 3, 5, 6, and 54). 


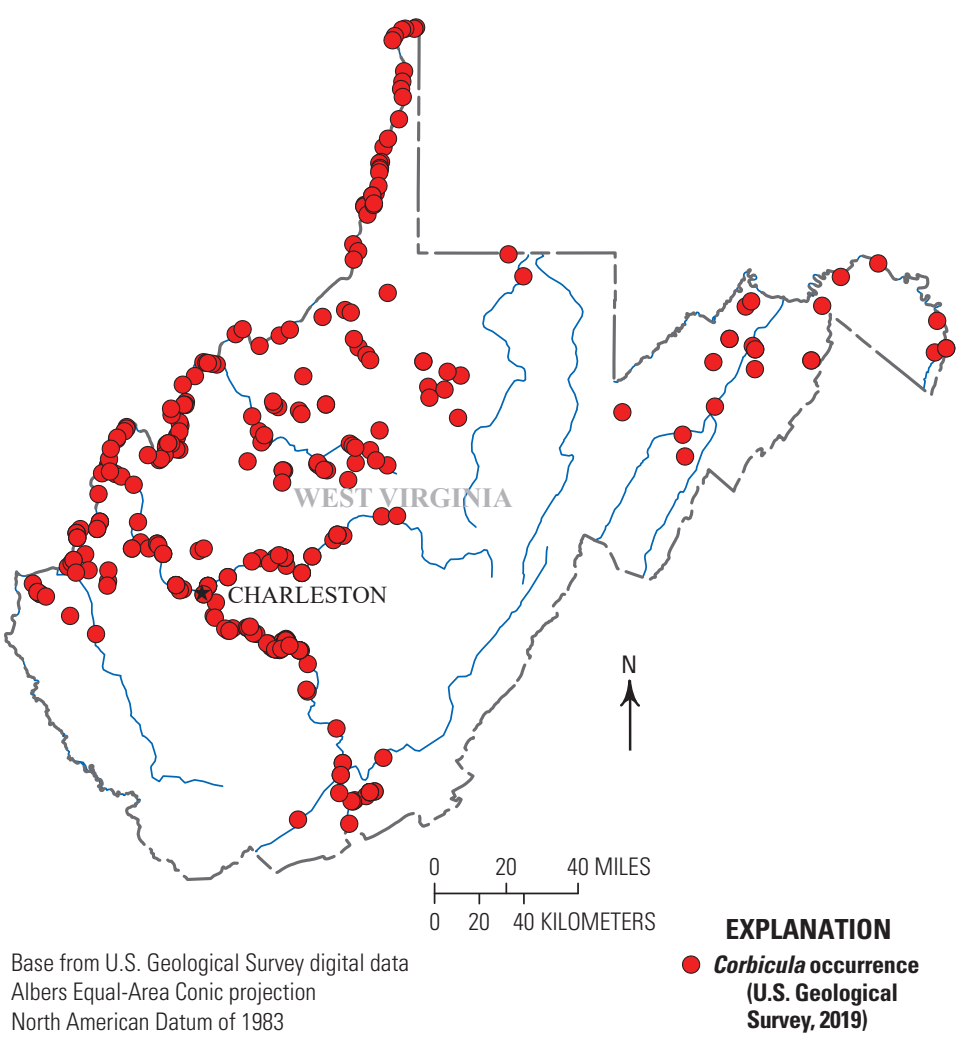

After 1984, Corbicula collection locations were reported to include the four tributaries of the Mississippi River in the State: Fox, Menominee (FMNH 327056), Mukwonago, and St. Louis Rivers. In 1999, a collection was made from the Fox River in a powerplant thermal effluent plume in the city of Green Bay, the first record from a Lake Michigan tributary in the State. Collections made in 2017 from the Fox River at thermal effluent locations contained only one live specimen (Smith and others, 2018b). The authors concluded that two extremely cold winters in succession caused high mortality in the warmwater refugia locations. Elsewhere in the State, collections were made in Spring Brook, a tributary of the Rock River near the Illinois border, in 2018 and 2019. Eleven lakes were added to the list of Corbicula occurrence locations: Andrea, Bohner, Browns, Eagle Spring, Lac La Belle, Little Muskego, Lower Phantom (Mukwonago River), Lulu, Paddock, Stratton, and Taylor. All but two of these lakes, Stratton and Taylor, are in southeastern Wisconsin, south of Milwaukee, and none are known to have thermal refugia. From 1978 to 2019, a total of 21 waterbodies have been found in the State with Corbicula. On the basis of this review, Corbicula has been found in 13 of 49 HUC8 subbasins and 15 of 72 counties in Wisconsin (figs. 3, 5, 6 , and 55).

Figure 54. Corbicula spp. occurrences in West Virginia through 2019.

\section{Wisconsin}

The first collection of Corbicula in Wisconsin was made in 1977 from the St. Croix River, a tributary of the Mississippi River, near Hudson (Fuller, 1978). The only other waterbody found to have Corbicula by 1984 was the Mississippi River, where the earliest collection occurred in 1979 (OSUM 75917). Counts (1991) listed no other records for Corbicula, nor did we find additional records for Wisconsin prior to 1985 .

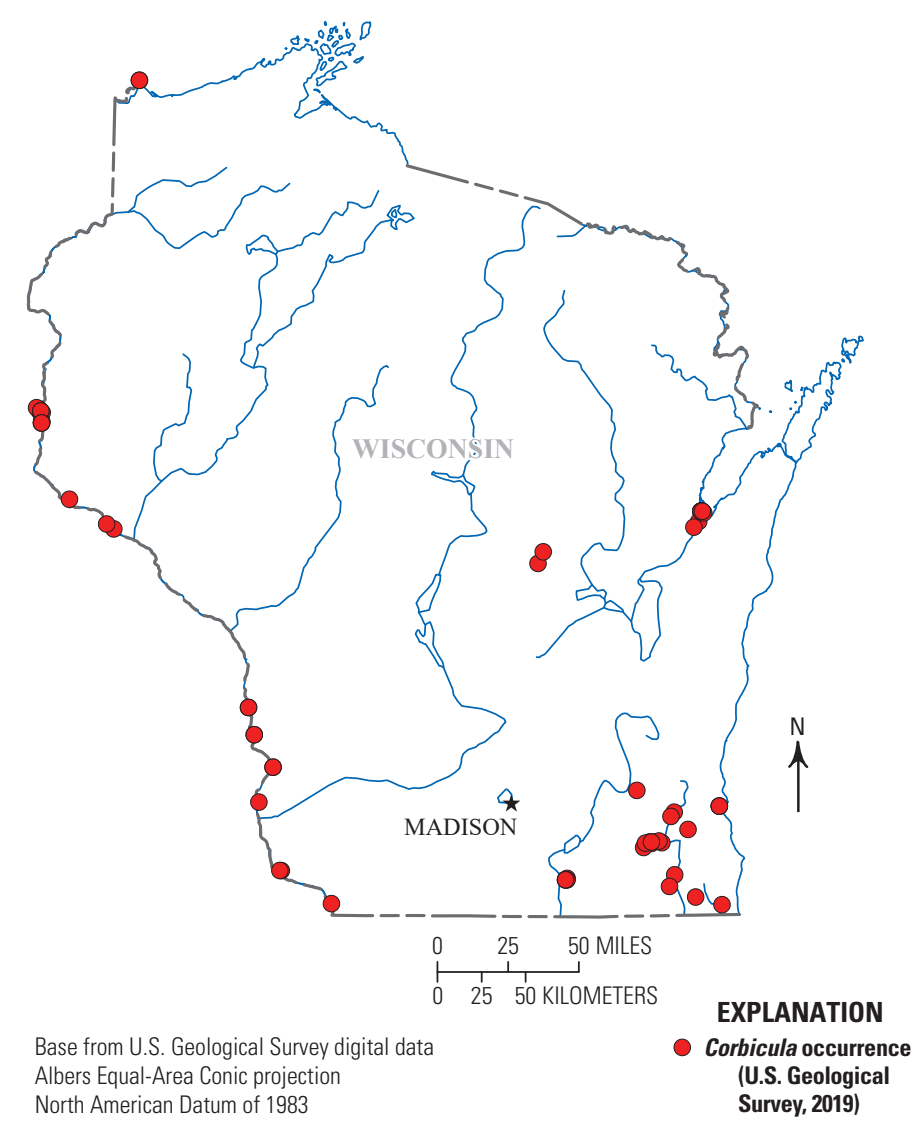

Figure 55. Corbicula spp. occurrences in Wisconsin through 2019. 


\section{Other Corbicula Species and Forms in the United States}

Recent genetic investigations involving Corbicula in midwestern U.S. rivers have revealed a complex taxonomic problem. During the past three to four decades, most collections of Corbicula in U.S. waterbodies have been reported in scientific literature and cataloged in museum collections as Corbicula fluminea. However, a limited number of collections have since been vouchered in museum collections as other species or forms of Corbicula. In summary of these other species, specimens identified as $C$. largillierti have been collected from numerous locations from Florida to Illinois but predominantly in the middle to upper Mississippi River Basin (Des Plaines, DuPage, Illinois, Kankakee, Mississippi, Missouri, and Ohio Rivers) beginning in 2008 (Illinois Natural History Survey, 2019; Douglass and others, 2020). Corbicula sp. Form D was first recognized in 2015 in the Illinois River (Tiemann and others, 2017; Haponski and Ó Foighil, 2019) and has also been found in the Des Plaines, Mississippi, Ohio, and Tennessee Rivers (Illinois Natural History Survey, 2019; Douglass and others, 2020). Additional studies would allow for the determination whether Corbicula sp. Form D has become established and, if so, determine its North American range, as well as that of $C$. largillierti.

\section{Canada}

Reports of Corbicula occurrences in Canada are confined to southern British Columbia on the Pacific Coast and to southern Ontario and Quebec Provinces in the Great Lakes-St. Lawrence drainage on the Atlantic Coast (fig. 4). The earliest evidence of Corbicula in North America came from several empty shells found by an unknown collector on a beach in Nanaimo, British Columbia, Canada, in 1924 (USNM 363020) (Counts, 1981). Following the initial discovery, more than eight decades passed until another collection was reported in the province beginning in 2008. Live specimens were found in a man-made park lake near Victoria on Vancouver Island in 2008 (RBCM 008-00017-001, 008-00019-001: Kirkendale and Clare, 2008), as well as in the northern arm of the Fraser River in Richmond in 2011 (RBCM 011-00282-001). Corbicula was collected at several sites along lower Fraser River and lower Pitt River (a tributary of the Fraser River) in 2014 (Holm, 2014) and at the confluence of the Coquitlam and Fraser Rivers in 2017. In 2017, a collection was reported for the first time from Kawkawa Lake (RBCM 020-00001-001), nearly $125 \mathrm{~km}$ east of the city of Vancouver, followed by a collection from Shuswap Lake (RBCM 020-00002-001) in 2019, approximately $320 \mathrm{~km}$ east of Vancouver. The first record of Corbicula in eastern Canada was a collection made in 1993 from the Severn River near Big Chute Marine Railway, Ontario (NCSM 55756). In 2001, it was found in Lake St. Clair off Squirrel Island, Ontario (CMN-ML 093852), part of the chain of Great Lakes. Eight years later, a population was discovered in the thermal effluent of a nuclear powerplant located on the St. Lawrence River, near Bécancour, Québec, in 2009 (Simard and others, 2012). This population was extirpated when the powerplant was permanently closed in 2012 (Castaneda and others, 2018). On the basis of this review, Corbicula has been found in 3 of 10 Canadian Provinces (fig. 4).

\section{Mexico, Central America, and Caribbean}

The earliest reported occurrence of Corbicula in Mexico was in about 1969 in an irrigation ditch just north of Cerro Prieto and south of Mexicali in the State of Baja California (Fox, 1970). Counts (1991) listed collections of Corbicula from 7 of 32 States, mostly in northern Mexico: Baja California (Colorado River), Jalisco, Nayarit, Nuevo Leon (Río San Juan), Sinaloa (Río Fuerte), Sonora (Colorado River, Río Mayo [UF 247535], Río Yaqui), and Tamaulipas (Río Carrizal, Río Comandante [UF 159751]). Although not specifically mentioned in Counts (1991), on the basis of collections made as early as 1975 in the upper Rio Grande in Texas (Davis, 1980), Corbicula was likely present in the border States of Chihuahua and Coahuila prior to 1985.

After 1984, Corbicula was collected in nine additional Mexican States (fig. 4). Collections were made in 1993 from an unspecified river east of the town of Xilitla (UF 211359) and in 1998 from the Río Huichihuayan (UF 270438), both in the State of San Luis Potosi. A collection was made in 1996 from the Río Conchos in Julimes, Chihuahua (UTEP 13683). In the State of Veracruz, collection locations include Laguna de Catemaco in 1992 (Torres-Orozco and Revueltas-Valle, 1996), Coatzacoalcos River Estuary in 2005 (Ruelas-Inzunza and others, 2007), and Tecolutla and Tuxpan Rivers in 2007 (López-López and others, 2009). From 2011 to 2015, BarbaMacías and Trinidad-Ocaña (2017) collected Corbicula in the States of Tabasco (Río Grijalva Basin), Oaxaca (Río Papaloapan Basin), and Chiapas (Río Usumacinta Basin) in southern Mexico. Corbicula collections from waterbodies in Mexico include the following additional States: Colima, Durango, Michoacán, and Zacatecas (Naranjo-García and Castillo-Rodríguez, 2017; López and others, 2019). Counts (1991) listed a single collection from the State of Jalisco in 1981 (UF 34919). Since then, additional collections were made from other locations in Jalisco in 2000 (Lee and others, 2005). It should be noted that $C$. largillierti has also been identified in Mexico (J. Tiemann, Illinois Natural History Survey, oral commun., 2019). In 2018, Corbicula (reported as C. largillierti) was collected from Río Conchos Basin in the State of Chihuahua (INHS 88776). On the basis of this review, Corbicula has been found in 16 of 32 Mexican States (fig. 4).

Corbicula has also been introduced in the country of Panama, where a collection was made in 1969 from the Río Chagres, near Gamboa in the Canal Zone (UF 247494). Additional collection locations include Río Santa Maria east of Santiago in 2001 (AUM 15376), Río Cascajal in 2001 (ANSP 410700: Counts and others, 2003), and Río Conaca near La Montañuela (NCSM 83316) in 2013. 
In the Caribbean region, Corbicula has also been found in Cuba. The first collection in the country was made in 1987 from Río Sagua la Grande in central Cuba (Milera and Quiros, 1995). It was also found in a Havana park pond in 2002 (UMMZ 300019: Lee and others, 2005). Beginning in 2004, Corbicula showed a history of rapid dispersal in Cuba when collections were made from numerous rivers and reservoirs in Holguin, Las Tunas, Santiago de Cuba, and Guantanamo Provinces in the eastern part of the country (Fernández and others, 2015). We found no collection or observation records for U.S. Virgin Islands territory.

\section{Discussion}

\section{Initial Introduction to North America}

Two hypotheses have been put forth as to how Corbicula arrived in North America. Even though it is a freshwater species tolerant of low salinity, the first hypothesis proposed that it may have arrived accidentally with seed oysters from Japan (Burch, 1944; Filice, 1958). Crassostrea gigas (Thunberg, 1793) (Pacific Oyster) was imported as early as the 1910s into British Columbia (Lavoie, 2005) and in the 1930s into California (Barrett, 1963). However, based on a genetic analysis, it was determined that Corbicula in North America is more closely related to those in China and the Philippines than to those in Japan (McMahon, 2000). The second hypothesis presumes a more deliberate introduction of Corbicula as a source of human food, in which it may have come with immigrants from the Zhu Jiang (Pearl River) region of China to the west coast of the United States (Fox, 1971b). Hanna (1966) also speculated that Corbicula was brought from China by immigrants in the 1920s. He found that residents in the SacramentoSan Joaquin Delta region of California had been using Corbicula as a food source since at least the mid-1940s. The latter hypothesis appears more plausible, as Corbicula is commonly found for sale in China. It has been intensively cultured there since the $1950 \mathrm{~s}$, when wild native populations began to fail because of industrial pollution (Chen, 1976). As many as 12 million tons have been harvested in a single year for sale in markets in China (Chen and others, 2013). In the United States, Corbicula has been sold in live food markets in Hawaii as early as 1977 (Burch, 1978). It was still for sale in the State as late as 2019 (fig. 56) even though it is on the prohibited species list in Hawaii (Hawaii Department of Agriculture, 2006). On the U.S. mainland, Corbicula has been offered for sale at food markets in Georgia and Texas as recently as 2015 (fig. 57). Corbicula was removed from the Texas prohibited species list because the spread was not believed to be by human activity that could be regulated (Howells, 1999). Corbicula can also be used in aquaria. We found it, as well as another invasive bivalve, Sinanodonta woodiana (Lea, 1834) (Chinese Pond Mussel), advertised for sale by online aquarium stores in the United States in 2020.

\section{Global Invasive Range}

Biological invasions are natural processes but not at the speed at which they are occurring today (Vitousek and others, 1996; Mack and others, 2000; Ricciardi, 2007). Recent invasions are not limited by political boundaries and no longer limited by geographic boundaries due to manmade globalization (Mack and others, 2000). Following the introduction to North America, Corbicula was later introduced and dispersed widely in South America and Europe. The earliest known collections in South America were made in the 1970s in Argentina and Uruguay (Ituarte, 1994) and also Brazil (VeitenheimerMendes, 1981). It appeared in Bacia Amazónica (Amazon Basin) of Brazil in about 1997 (Beasley and others, 2003) and in Ecuador and Peru by 1999 (Lee and others, 2005). In Europe, the earliest collections were made in France and Portugal in about 1980 (Mouthon, 1981). Corbicula continued to disperse throughout Europe to include Spain (Araujo and others, 1993), Germany (Kinzelbach, 1991), England (United Kingdom) (Baker and others, 1999), Hungary (Csányi, 1999), Czechia (Czech Republic) (Beran, 2000), Bulgaria (Hubenov, 2001), Belgium (Nguyen and De Pauw, 2002), the Netherlands (Bij de Vaate and Greijdanus-Klaas, 1990), Switzerland (Rey and Ortlepp, 2002, as cited in Schmidlin and Baur, 2007), Serbia (Paunović and others, 2007), Poland (thermal effluent of a power station) (Domagala and others, 2004), Republic of Moldova (Munjiu and Shubernetski, 2010), Ireland (Sweeney, 2009), and Northern Ireland (Caffrey and others, 2016). In 2016, an established population was found in a powerplant thermal effluent channel of the Kuznechikha River in northern European Russia, the northernmost population of Corbicula in the world (Bespalaya and others, 2018). Although native to all but northwestern Africa, the first introduced population was discovered in Morocco in 2008 (Clavero and others, 2012). Corbicula fluminea has not been reported from Australia (Gama and others, 2017).

\section{Invasive Characteristics and Dispersal}

Corbicula is an especially efficient invader, as it is a simultaneous hermaphrodite capable of incubating selffertilized eggs (Kraemer, 1978); therefore, it is possible to start a population from a single individual (McMahon, 2000). On its own, Corbicula is quite capable of dispersing naturally, especially at the veliger and pediveliger stages (McMahon, 2000). Although the planktonic pediveliger does not actively swim (Kraemer and Galloway, 1986), swift currents can transport it long distances before it eventually settles to the bottom, where it is then able to move short distances by utilizing its foot (McMahon, 2000). Prezant and Chalermwat (1984) showed that small adults in both the laboratory and the field can also disperse by producing a mucous thread that acts like a sail in the current, picking them up off the substrate and depositing them downstream. The downstream passive hydrological transport of pediveligers is its main mode of dispersal (McMahon, 2000). 


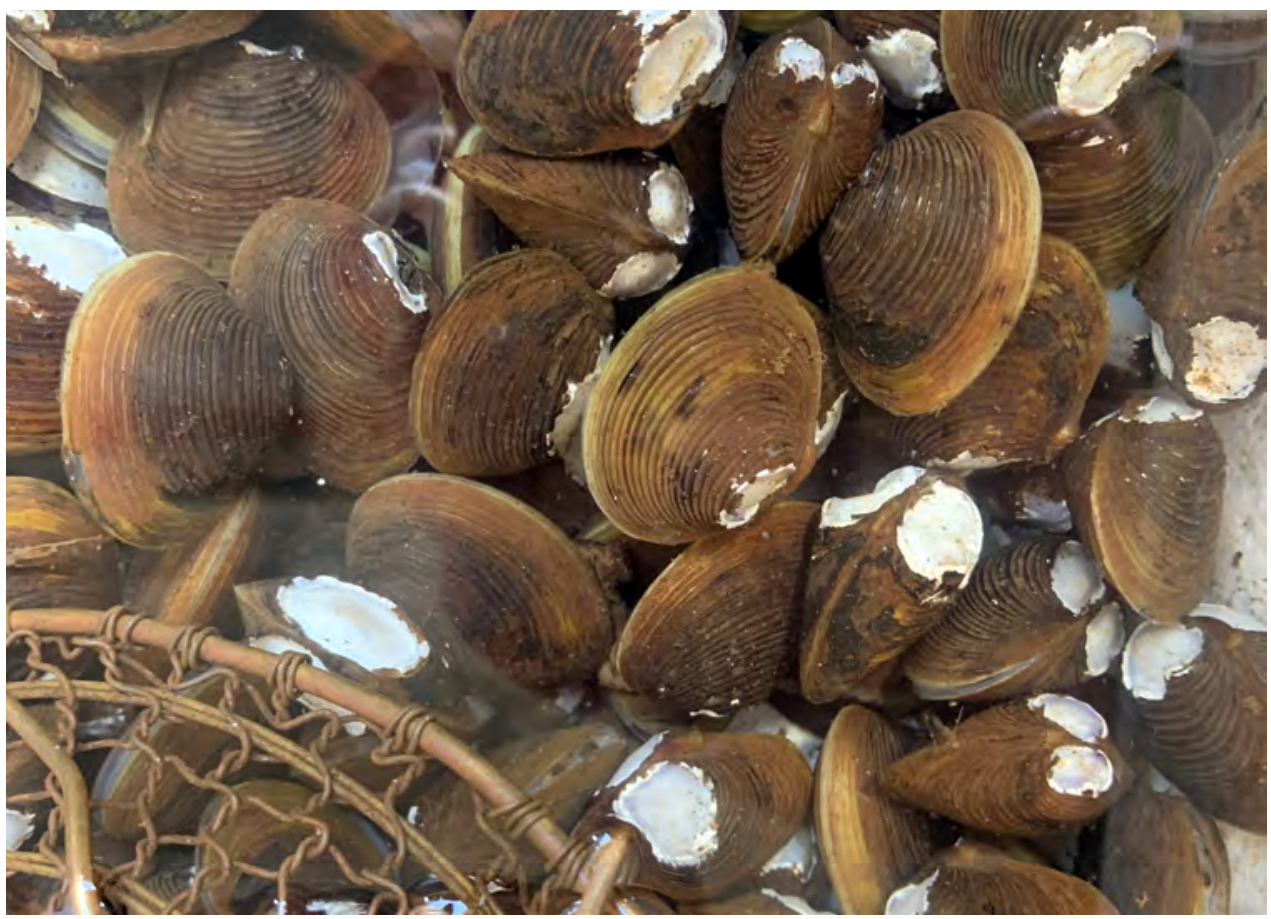

Figure 56. Corbicula for sale in Hawaii at a live food market in 2019. Photograph by Leo G. Nico, U.S. Geological Survey.

A

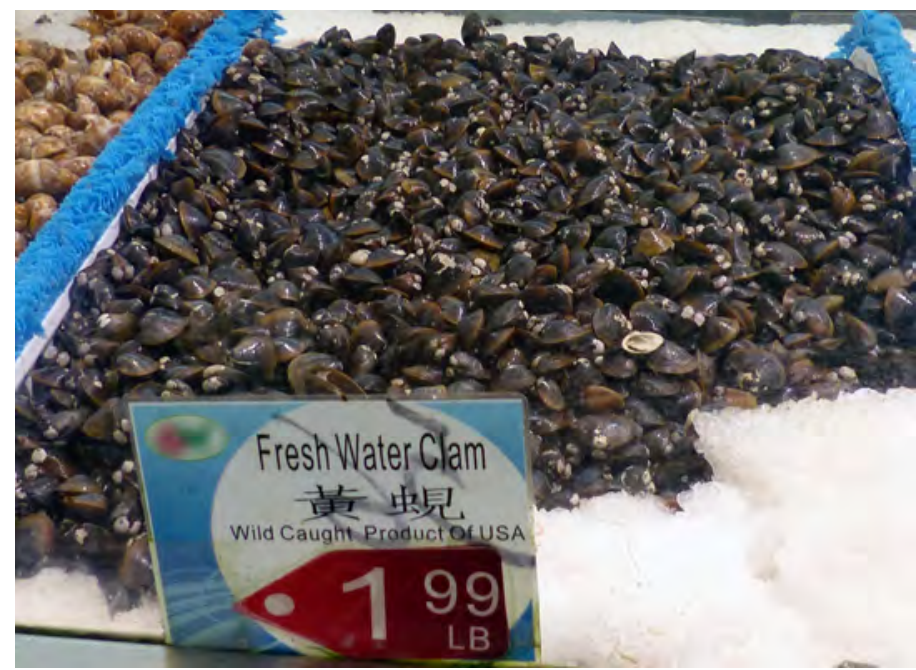

$\boldsymbol{B}$

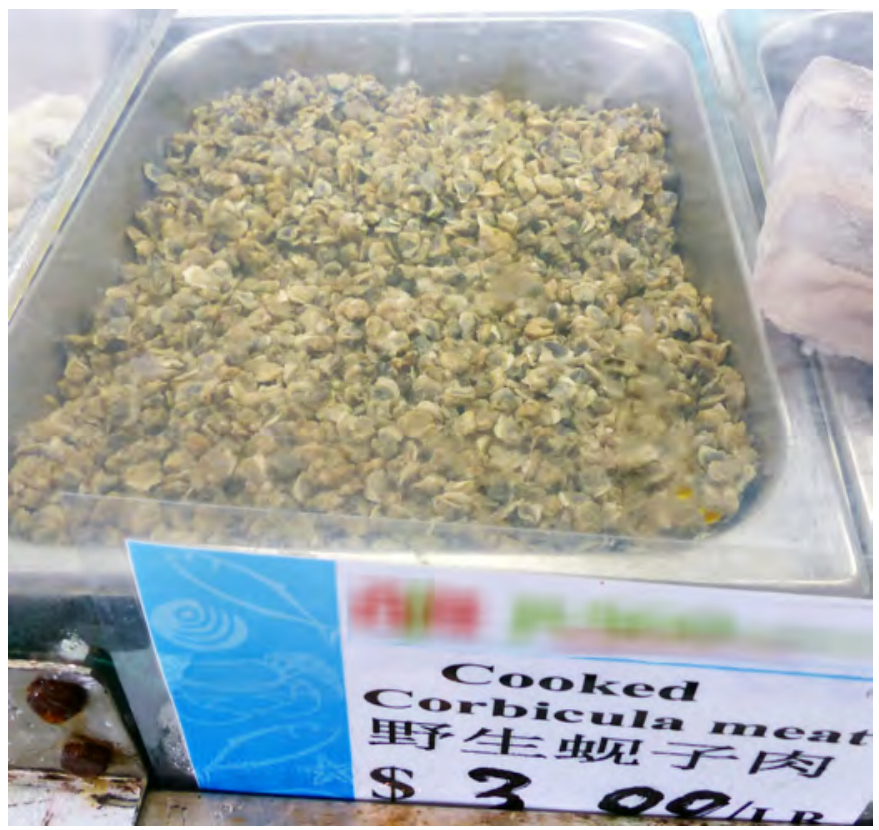

Figure 57. Corbicula for sale in $A$, Georgia and $B$, Texas food markets in 2015. Photograph by Leo G. Nico, U.S. Geological Survey. 
Sinclair and Isom (1963) likened the early rapid dispersal of Corbicula in the United States to the spread of Dreissena mussels in Europe in the 1800s. This rapid dispersal (fig. 58) begs the question of how Corbicula dispersed so quickly beyond physical barriers that would naturally limit its distribution once introduced in the United States. Unfortunately, direct evidence of dispersal mechanisms over long distances in North America is essentially absent. We attribute the lack of evidence of dispersal, at least in part, to the absence of biological sampling and monitoring of streams during the 1950s and 1960s, a period of rapid and long-distance range expansion of Corbicula. Attitudes changed substantially in the 1970s with the passage of national legislation, such as the National Environmental Policy Act, Endangered Species Act, and Clean Water Act, all of which required increased attention to sampling and monitoring of aquatic habitats. Awareness of the potential ecological disruption to aquatic ecosystems by Corbicula was elevated in State and Federal natural resource agencies, resulting in increased reporting of its occurrence.

The dispersal of invading bivalves such as Corbicula and D. polymorpha by other animals was reviewed by Coughlan and others (2017). On the basis of their review, only five studies concluded that, although it was possible, dispersal by other animals would be a low probability and slow process. McMahon (1982) also believed that long-distance transport of larvae by waterfowl, whether in the gut or entangled on their feet or feathers, was not likely. However, although not reported in freshwater environments, live Cerastoderma edule (Linnaeus, 1758) (Common Cockle) have been found clamped to the feet of wading birds (Green and Figuerola, 2005). There are few examples of short-distance transport by vectors other than waterfowl. It has been shown that Corbicula can pass alive through the gut of wild-caught Cyprinus carpio Linnaeus, 1758 (Common Carp) (French, 1993) and the migratory Ictalurus furcatus (Valenciennes, 1840) (Blue Catfish), which both lack pharyngeal teeth for crushing shells (Gatlin and others, 2013). Although unlikely, it has also been suggested that upstream dispersal may be possible if fish were to become entangled in the byssal threads of Corbicula (Barnhart and others, 2008). In a study conducted in a pristine environment where access by humans was very limited, Voelz and others (1998) found that Corbicula moved upstream at a rate of $1.2 \mathrm{~km}$ per year unassisted by humans, birds, or fish. In large lakes, it was concluded that young Corbicula, aided by their byssal threads, could be dispersed from wind-driven currents more than $5 \mathrm{~km}$ over a 6-year period (Minchin and Boelens, 2018). Using hydrodynamic drag force models for Lake Tahoe, Forrest and others (2017) predicted that all size classes of Corbicula could also be transported passively by wind-driven currents.

There is little doubt that, with the speed and distances at which Corbicula dispersed across oceans and river drainage divides, anthropogenic vectors such as human migration and international trade played a major role in the species' dispersal (Karatayev and others, 2007). Once Corbicula was in the United States, canals such as the Colorado River Aqueduct in the Coachella and Imperial valleys of southern California were inundated with Corbicula by the mid-1950s (Ingram, 1959) and in the Delta-Mendota Canal in central California by the late 1960s (Fox, 1971a) and likely delivered Corbicula throughout their respective systems. Britton and Murphy (1977) suggested that Corbicula larvae were unintentionally transported in shipments of minnows to bait stores. Another vector that likely helped the dispersal of Corbicula was its intentional availability at bait shops. Corbicula was sold as live fish bait in California, as much as 2 million pounds over a 6-year period in the 1960s (Fox, 1971a). In addition to the availability in California, Corbicula was being commercially harvested from the lower portions of both the Tennessee and Cumberland Rivers in Kentucky exclusively for the fish bait industry from the late 1960s to the mid-1970s, until the population mysteriously crashed in 1978 (Sickel and others, 1981). Corbicula as a human food item also presents an opportunity for possible dispersal. An example of this occurred in New York when local food inspectors discovered Corbicula in shipments of hard clams, Mercenaria mercenaria (Linnaeus, 1758) (Northern Quahog), from California destined for area restaurants (Foehrenbach and Raeihle, 1984). The authors also stated that at least one California bait dealer was selling Corbicula to restaurants. Scientific research can also be a potential precursor for dispersal. Also from bait shops in California, Corbicula was purchased and shipped alive to the State of Wisconsin for immunology research (Yang and Yoshino, 1990). Even though there was mounting evidence of the potential economic and ecological impact from invading Corbicula, it was never considered for placement on the Federal injurious wildlife list, and there are no Federal restrictions regarding its transport across State lines. However, in some States it may be illegal to transport them into the State and release them into open waters.

Another possible vector or mechanism for Corbicula range expansion is climate change. Modeling Corbicula affords the opportunity to predict a future distribution under changing climate conditions. Gama and others (2016) showed that climatic variables of a model or climatic and topographic variables of a combined model, as opposed to a topographic model only, were the most accurate predictors of Corbicula distribution worldwide. In a study of future invasions in the Great Lakes, Pagnucco and others (2015) used an algorithm that predicted a high risk of establishment under a climate change scenario for Corbicula to invade Lake Huron and Lake Ontario where Corbicula have yet to be reported. McDowell and others (2014), using logistic regression and Maxent (https://biodiversityinformatics.amnh.org/open_source/ maxent/) models, found that the climate variables of precipitation in the driest month and minimum temperature in the coldest month were the most important drivers of Corbicula distribution, more so than habitat variables. They concluded that as the climate changes with increasing temperatures the distribution of Corbicula will likewise increase. Reyna and others (2018) also found the minimum temperature in the coldest month to be the most important predictor and concluded that increasing global temperatures favored the 


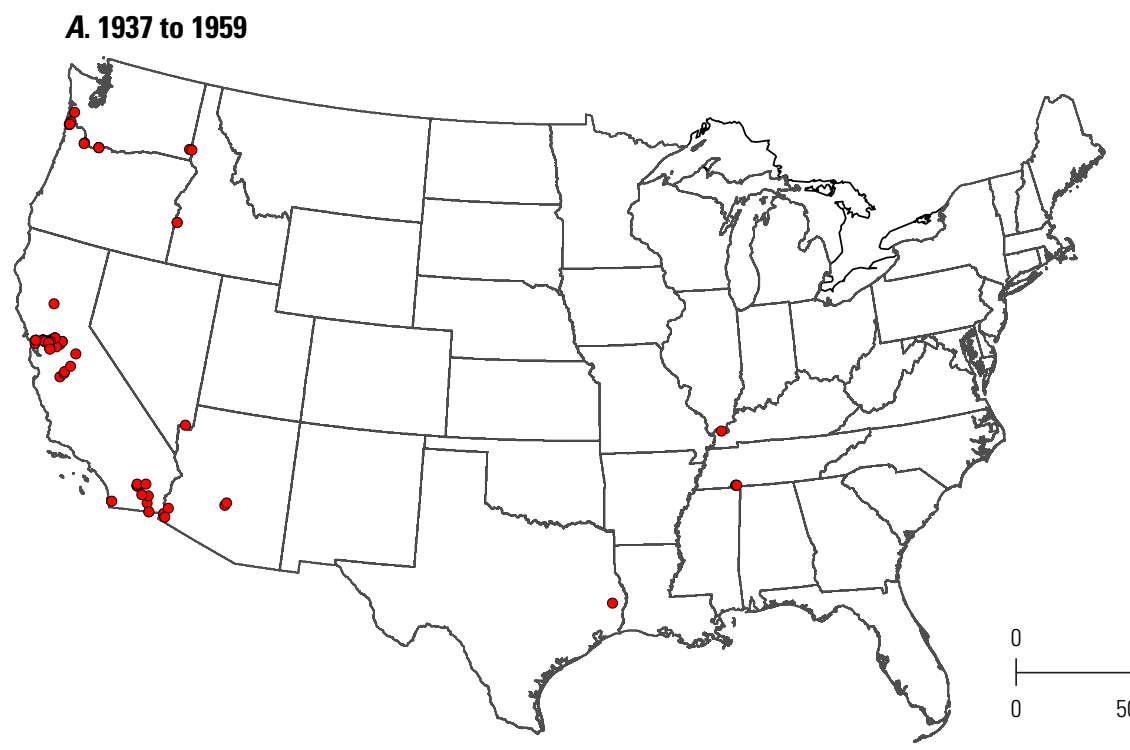

\section{B. 1960 to 1979}

C. 1980 to 1999
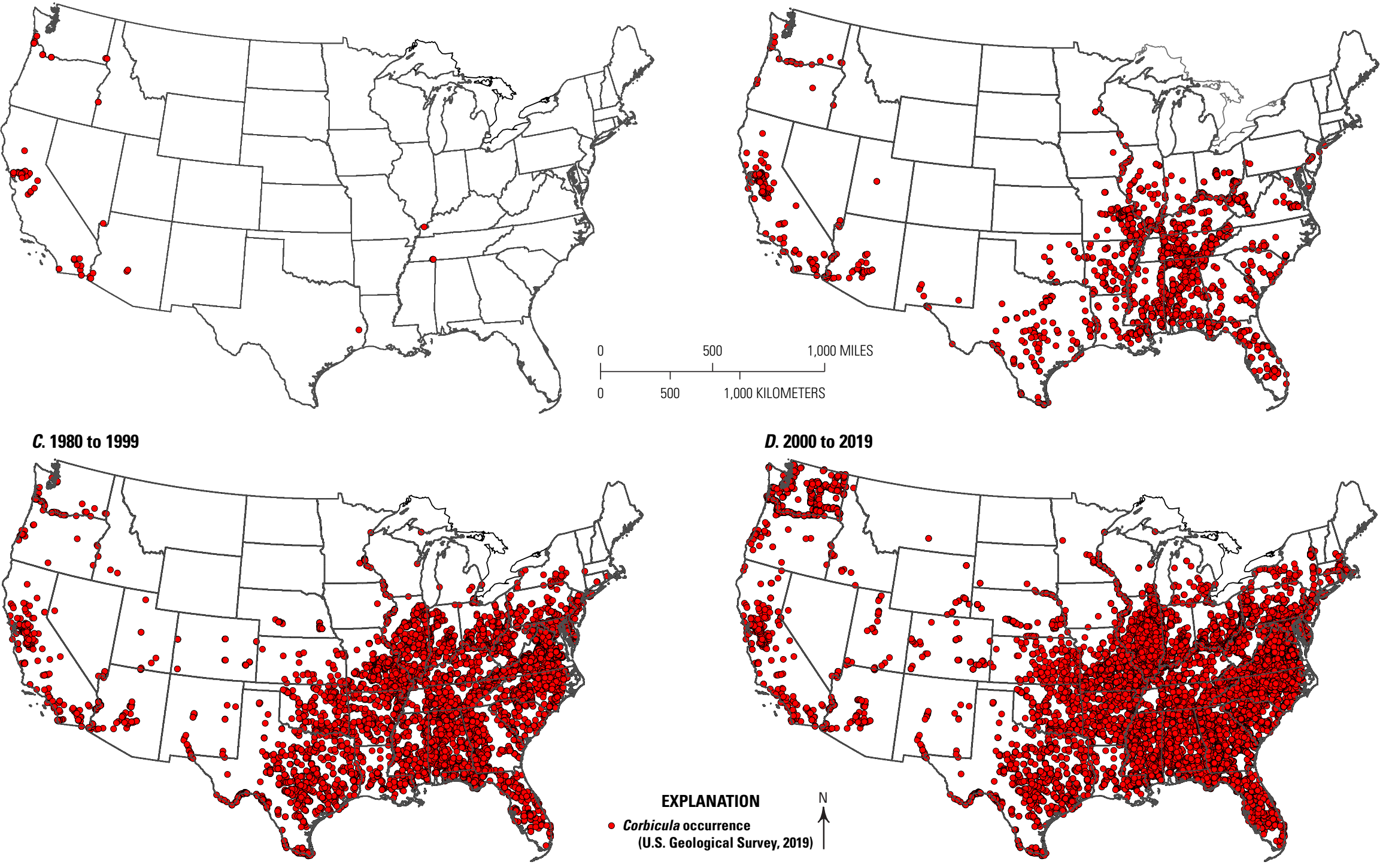

Figure 58. Corbicula spp. occurrences over time in the United States. A, 1937 to 1959; B, 1960 to 1979; C, 1980 to 1999; and D, 2000 to 2019. 
dispersal of Corbicula species. Gama and others (2017) modeled the distribution under increasing carbon dioxide emission scenarios and came to a similar conclusion that Corbicula has great potential to expand its distribution under current climate change conditions. In laboratory experiments, Weitere and others (2009) found that environmental warming in summer and winter could be both detrimental and beneficial in terms of growth rates, reproductive success, and mortality. On the basis of their field experiments, a temperature increase of 3 degrees Celsius $\left({ }^{\circ} \mathrm{C}\right)$ above the natural temperature resulted in a decrease in growth rates and a higher mortality rate in summer, but in winter showed a positive effect on both growth and reproduction rates.

\section{Temperature Tolerance}

The long-term absolute lethal upper temperature limit of Corbicula has been reported to be approximately $36{ }^{\circ} \mathrm{C}$ (McMahon and Williams, 1986) and the lower limit to be $2{ }^{\circ} \mathrm{C}$ (Mattice and Dye, 1975). However, at the lower limit laboratory experiments have shown that Corbicula can tolerate short cold periods (4 weeks) of $0{ }^{\circ} \mathrm{C}$ (Müeller and Baur, 2011). The minimal temperature for reproduction is $15{ }^{\circ} \mathrm{C}$ (McMahon, 2000 ), and an optimal growth rate model predicted the temperature near $20^{\circ} \mathrm{C}$ (Foe and Knight, 1986). McMahon (1982) suggested that Corbicula had reached its northern limits in North America and could only survive in northern regions by using industrial thermal effluent or refugia. Through the early 1980s, established populations of Corbicula were primarily known only from below approximately the 40th parallel except those in Oregon and Washington, while those found north of the 40th parallel elsewhere in the United States were primarily found in thermal refugia (Kreiser and Mitton, 1995). Smith and others (2018a) found that populations living in powerplant thermal effluent along the shores of Lake Michigan failed once the warmwater sources were gone. Evidence to the contrary, Corbicula appears to be surviving without the presence of artificial or natural thermal discharges in Colorado (Kreiser and Mitton, 1995), Connecticut (Morgan and others, 2003), Michigan (Janech and Hunter, 1995), Minnesota (U.S. Army Corps of Engineers and others, 2010), New Hampshire (Richardson and Selby, 2020), New York (Lake George Park Commission, 2017), South Dakota, and Wisconsin (U.S. Army Corps of Engineers and others, 2010). Cordeiro and MacWilliams (1999) reported finding reproducing populations of Corbicula at several locations in Colorado where temperatures drop below $2{ }^{\circ} \mathrm{C}$. Survival of Corbicula at temperatures below $2{ }^{\circ} \mathrm{C}$ suggests the possibility of some adaptive selection for tolerance to lower temperatures (Richardson and Selby, 2020).

\section{Economic and Ecological Impacts}

Less than two decades after the first population was discovered in North America, Corbicula was recognized as a nuisance species with realized negative economic impacts.
As early as 1953 , it had begun to cause problems with water delivery for the extensive irrigation canal systems of California (Ingram, 1959). After the introduction to the eastern United States, Corbicula had become significant biofoulers of powerplants on the Tennessee River in Tennessee by 1957 (Sinclair and Isom, 1961). McMahon (1982) mentioned many instances of the damage and interference with mechanical operations that Corbicula caused in industrial settings simply by the sheer volume of shells. Any facility, including nuclear powerplants, drawing raw water where Corbicula was present had the potential for operational problems. For example, in 1980 a unit at Arkansas Nuclear One on the Arkansas River was shut down to remove large numbers of Corbicula individuals from the containment air coolers (Isom, 1986; Page and others, 1986). By the early 1980s, nationwide annual costs from losses, damages, and control of Corbicula were estimated at 1 billion dollars (Isom, 1986). Since then, a number of nuclear powerplants were retired in the 2010s for economic reasons, and more were announced for closure in the $2020 \mathrm{~s}$ (Scott and Comstock, 2019), likely reducing the overall cost of damage and maintenance related to Corbicula. Although incidents of heavy biofouling appear either less prevalent or unreported, power generation and industrial facilities that rely heavily on water for cooling or manufacturing still incur direct costs for prevention, monitoring, and control of Corbicula and Dreissena spp. (Rosaen and others, 2012). In industrial settings the potential will always exist for equipment, including water intakes, wells, trash racks, screens, gates, pumps, turbines, heat exchangers, condensers, and fire protection systems, to be impacted by the presence of Corbicula and other biofouling bivalves (Mackie and Claudi, 2010).

Invasive species can have devastating ecosystem transforming effects in natural settings that can directly or indirectly impact the environment and other aquatic organisms (Mack and others, 2000). Numerous studies have found Corbicula to have broad effects that include influencing seston size (Leff and others, 1990); decreasing chlorophyll a (Cohen and others, 1984; Beaver and others, 1991; Pigneur and others, 2014; Marescaux and others, 2016); depressing phytoplankton abundance (Cohen and others, 1984); altering food webs, biogeochemical cycling, oxygen budget, and nutrient cycling (Lauritsen and Mozley, 1989; Beaver and others, 1991; Cooper and others, 2005; Atkinson and others, 2010; Pigneur and others, 2014); influencing carbon dynamic and stored organic materials in sediments (Hakenkamp and Palmer, 1999); decreasing abundance of bacteria and flagellates (Hakenkamp and others, 2001); affecting sediment distribution dynamics (Hakenkamp and Palmer, 1999; Majdi and others, 2014); and having an association with an increase in algal blooms (Forrest and others, 2012). In addition to this long list of impacts, a high density of Corbicula shells in the substrate may also influence the epibenthic fauna (that is, fishes and crustaceans) by providing a complex habitat for small prey species that may favor some predators and negatively impact others (Ilarri and others, 2014). 
After the arrival Corbicula in the Mississippi River Basin and southeastern U.S. drainages, there was much concern over the potential for negative impacts on the native mussel fauna, a highly diverse and imperiled group of organisms in the United States (Williams and others, 1993). Haag (2019) considered Corbicula as the single most important factor causing the broad decline in native mussel populations in the United States. Gardner and others (1976) reported drastic decreases in native mussel abundance coinciding with the arrival of Corbicula in the Altamaha River in Georgia. However, they admitted that the decline could have been a combination of factors, one of which included Corbicula. Diminished growth rates of native mussels have also been reported with the presence of Corbicula (Belanger and others, 1990; Lopes-Lima and others, 2017). Some research has shown negative effects, whereas other studies have hypothesized the potential for negative effects through field and laboratory experiments, as well as in the use of models. Laboratory studies have predicted some potential negative impacts of Corbicula on native mussels such as limiting planktonic food because of its high filtering rate (Cohen and others, 1984); affecting growth, condition, and locomotion of native mussels (Ferreira-Rodríguez and others, 2018b); reducing food and habitat of native mussels (Atkinson and others, 2011); and ingesting glochidia and juvenile native mussels (Yeager and others, 2000; Modesto and others, 2019). In addition, Corbicula seems to be susceptible, yet resilient, to large natural die-offs often due to higher temperatures and lower oxygen during low flow or drought conditions; however, its decomposition creates poor water quality negatively impacting native mussel species (Cherry and others, 2005; Cooper and others, 2005; McDowell and others, 2017). In a heat wave or drought condition, the presence of Corbicula may additionally limit the ability of native mussels to follow receding waters (Ferreira-Rodríguez, 2019). Related to climate in a climate change scenario, Corbicula may negatively impact native mussels through resource competition (Ferreira-Rodríguez and Pardo, 2017; Ferreira-Rodríguez and others, 2018a). Strayer (1999) summarized the impacts of Corbicula on native mussels, both real and perceived, and hypothesized that Corbicula successfully invades mussel beds when native mussel populations are on the decline and that any negative impacts could be slow and insidious where declines in native mussels' recruitment may not become evident for years. Furthermore, Strayer (1999) stated that reported impacts have been largely based on spatial distribution studies at a single point in time and may be misleading; therefore, changes over time after the arrival of Corbicula may be more revealing.

Some research has suggested that it may not always be the case that the invader has the advantage. Slow-growing native mussels may actually have a competitive advantage over the fast growth and higher energy demands of Corbicula in dense mussel beds (Vaughn and Spooner, 2006). When comparing large and small spatial scales, Vaughn and Spooner (2006) found that at a small spatial scale of $0.25 \mathrm{~m}^{2}$ the distribution and abundance of Corbicula was negatively related to the abundance of native mussels. Therefore, they believed that this likely lessened the chance of a successful invasion simply due to the lack of space. When these small study units were pooled together over an entire stream reach, that relationship was absent; densities of Corbicula varied widely where there were few or no native mussels. To further determine impacts, they suggest more field studies are needed of Corbicula and native mussel interactions at a small scale. Olden and others (2006) suggested that Corbicula does not replace native mussels; it simply fulfills an empty niche in a human disturbed habitat not preferred by natives. After studying Corbicula in altered and unaltered habitats, Kraemer (1979) concluded as follows: Corbicula takes advantage of disturbed or altered habitat such as that from dredging activity where a preferred habitat is created but where natives prefer not to live, Corbicula coexists with natives in unaltered habitats, and some native mussels are better adapted than Corbicula to live in rivers. Sousa and others (2014) mentioned the potential for invasive mussels to shift the genetics of native species through natural selection that may allow for invaders and natives to coexist. Native mussels and Corbicula have coexisted for many years in the United States, and their interactions are still not completely understood (Haag, 2012, 2019). Clearly there are conflicting studies as to whether Corbicula negatively impacts native mussels, as well as to the approaches used for those studies. It is likely that the range of negative impacts on native freshwater mussels will vary geographically across river drainages and diverse habitats.

\section{Prevention, Management and Control, Eradication}

Corbicula appeared in the United States prior to the broader awareness of invasive species issues that began in the 1970s and continues today. Therefore, little to no information exists on efforts to prevent its dispersal in the early years and for decades after its introduction. This species is ubiquitous in open waters across much of the United States, so much so that management, control, and eradication efforts of large populations would not be cost effective with the tools available and are therefore not generally under consideration. Historically, there were suggestions to exploit this species in the 1960s and 1970s such as using its filtering capability for wastewater treatment and using waste heat of powerplants in aquaculture production for human consumption (Mattice, 1977). However, there is no evidence that these uses were realized. Though Corbicula is broadly distributed, as previously stated, there are waterbodies where it does not occur. Some recent efforts have been made to prevent dispersal, for example, to prevent the dispersal primarily of veligers through aquaculture and hatchery activities. A molluscicide (potassium chloride and formalin) used to kill Dreissena spp. veligers was found to be 100 percent effective against Corbicula veligers after several hours of exposure (Layhee and others, 2014). The more recent appearance of Corbicula in Europe has drawn more interest in 
preventing its further dispersal (Coughlan and others, 2019). Environmentally friendly protocols using hot water and steam for cleaning are very effective and recommended as opposed to chemical disinfectants to help stop further dispersal via overland transport (Coughlan and others, 2019).

Early detection is an important factor in the management of invasive species. Often by the time a species is detected through standard survey techniques, it is well established beyond the limitations for eradication (for example, Zebra Mussel). Environmental DNA (eDNA) has quickly become a promising tool to detect invasive species before they are visible as individuals or as a population. Cowart and others (2018) successfully developed an eDNA assay to detect Corbicula, which could be used as part of an integrated surveillance program. Early detection may be viewed as a prevention tool and as a management tool with which managers can make decisions on whether to allow watercraft from potentially infested waters to enter uninfested waters. With the addition of eDNA as a monitoring tool for early detection, it may be possible for natural resource agencies to manage and perhaps limit the future dispersal of Corbicula and allow for possible eradications of some small populations (Cowart and others, 2018).

The need for management and control of Corbicula in industrial settings was realized by the 1950s. Control of biofouling mollusks can be achieved in industrial water systems through the use of physical and chemical means including drying, freezing, low oxygen, filters, electricity, acoustics, ultraviolet light, ozone, chlorine, copper sulfate, and potassium chloride, of which any can be successful in a particular setting (Mackie and Claudi, 2010). A variety of control methods that include chemical, nonchemical, and mechanical for both industry and open waters are reviewed and summarized in Sousa and others (2014). What is considered successful control of any invasive species varies widely and generally requires a long-term commitment (Mack and others, 2000).

In open waters of the United States, efforts at eradication have been very limited in number. However, attempts were made in portions of two large waterbodies where Corbicula was a recent introduction and therefore not widely distributed, Lake Tahoe in Nevada and Lake George in New York. Both eradication efforts used large barrier mats (ethylene propylene diene monomer) as the treatment to cover Corbicula beds, thereby significantly reducing oxygen levels. In JulyNovember 2010, the treatment at Lake Tahoe achieved a 98-percent reduction after 120 days, and a reduction greater than 90 percent of Corbicula was maintained for 1 year (Wittmann and others, 2012b). Prior to the use of barrier mats, suction dredges were used at Lake Tahoe in 2009, and the number of individuals was reduced by 96 percent; however, the population began to recover after 240 days (Wittmann and others, 2012a). A similar eradication was attempted in Lake George in 2011, 1 year after the population was discovered and presumed to be limited in its distribution. Barrier mats covered approximately 2.4 hectares of Corbicula beds for 45 days, but unfortunately more individuals were found later that same year at other locations in the lake (M. Modely, Lake
Champlain Basin Program, written commun., 2011). From the time that Corbicula was discovered in 2010, more than $\$ 2$ million was spent on research and eradication attempts (Lake George Park Commission, 2016). It quickly became cost prohibitive to spend approximately $\$ 80,000$ per acre only to be able to control Corbicula and not eradicate it (Lake George Park Commission, 2017). By 2019, Corbicula had occupied more than 60.7 hectares of lake bottom at 27 separate locations in Lake George (Lake George Park Commission, 2019). In Europe, where the earliest introduction of Corbicula has been more recent, opportunities for dispersal prevention and control may be possible. Sheehan and others (2014) used mechanical dredging as a tool to help control a dense population of 17,872 individuals per square meter in the River Barrow of Ireland. This method was highly effective at reducing numbers and biomass of Corbicula, but the authors recommended it only be used on high density populations to lessen the damage to other organisms cohabitating in low density Corbicula populations (Sheehan and others, 2014). Unfortunately, these methods may only be short-term control strategies for high density populations.

Natural controls of Corbicula are present in the environment. Natural die-offs have been observed, of which the majority were attributed to issues associated with overpopulation (Sickel, 1986). Other natural controls such as climate and weather events that cause die-offs due to cold water (Sinclair and Isom, 1963; Horning and Keup, 1964); flooding (Britton and Morton, 1979); and droughts, which bring low flow, high temperatures, elevated ammonia, and low dissolved oxygen (Ilarri and others, 2011; McDowell and others, 2017), may only minimally impact Corbicula populations. Predation by native species has also been examined as another way in which Corbicula can be negatively affected. There are a number of examples in which fishes may be the most important group of predators. Robinson and Wellborn (1988) compiled a list of more than a dozen fish species known to prey on Corbicula. Their study in a large Texas reservoir, with seven of these fish predators present, indicated that predation can negatively impact Corbicula density. Fish predation also may have been responsible for high mortality of young Corbicula in a constructed Illinois lake (Dreier and Tranquilli, 1981). In the Columbia River of the Pacific Northwest, Corbicula was found to be an important prey species in spring and summer for juvenile Acipenser transmontanus Richardson, 1836 (White Sturgeon) (McCabe and others, 1993). Corbicula has been found in the stomachs of Acipenser oxyrinchus desotoi Vladykov, 1955 (Gulf Sturgeon) in the Suwannee River, Florida, and while it was likely ingested by large sub-adult sturgeon exploring for preferred prey, it may also be prey for the small juvenile sturgeon (Mason and Clugston, 1993). Mylopharyngodon piceus (Richardson, 1846) (Black Carp) was imported into the United States from Asia in the 1980s because of its potential to control a parasite of aquatic snails in commercial catfish aquaculture ponds (Nico and others, 2005). Black Carp escaped aquaculture in the late 1990s and soon became established in the Mississippi River. Native to China, 
Black Carp can grow to more than $1.5 \mathrm{~m}$ in length and $70 \mathrm{~kg}$ in weight and are known to be a consumer of Corbicula in its native range (Nico and others, 2005, see references therein). As evidence, Poulton and others (2019) found Corbicula in 3.7 percent of the total number of Black Carp examined from the Mississippi River. Unfortunately, Black Carp may also consume native mollusks, many of which are designated as threatened or endangered species; therefore, it would not likely be viewed as a control of wild populations of Corbicula. In a study of commercial fish landings in a Brazilian reservoir where Corbicula was widely available, Corbicula was found in the gut of most of the fish species present; however, it was not the dominant prey item (de Oliveira and others, 2010). The authors concluded that, in order for a particular fish species to be an effective predator of Corbicula, it would have to be pre-adapted (for example, molariform teeth) to a mollusk diet in order to break the shells. Similar to Gatlin and others (2013), de Oliveira and others (2010) suggested that undigested Corbicula found in the gut of fishes could possibly pass through alive, which may disperse them as opposed to control them. To the contrary, Minckley (1982) found that common carp, Ictalurus punctatus (Rafinesque, 1818) (Channel Catfish), and several other predator fish species digested Corbicula without breaking the shell, especially those smaller than $1 \mathrm{~cm}$. In addition to fishes, it has also been suggested that crayfish may be an effective predator of small Corbicula (Covich and others, 1981; Pereira and others, 2016). Waterfowl, specifically diving and surface-feeding ducks known to be benthic predators, were examined during a study at a constructed Illinois lake where nearly all species had ingested Corbicula (Sanderson and Anderson, 1981). In another study, it was determined through the use of exclosures that ducks did have a predation effect on Corbicula at a reservoir in South Carolina (Smith and others, 1986). Considering its high rate of reproduction, natural predators are unlikely to control Corbicula populations in most aquatic systems.

\section{Conclusion}

Since the arrival of Corbicula in North America, its occurrence and subsequent reporting has often been taken for granted and likely suffers from the "it is everywhere" syndrome in areas where it has existed for decades. As a result, records from native mussel surveys and museums documenting range expansions in the past several decades are relatively sparse, especially in some States, Provinces, or regions. Corbicula is often overlooked in stream sampling when it is not part of surveys targeting native mollusk fauna. It may be present in surveyed streams but is simply not documented in reports or museum vouchers. We suspect that it is present in numerous waterbodies in a number of States in addition to those compiled in this review. We expect occurrences of Corbicula, as well as recognition of novel species and "forms," to increase into additional water bodies either from the actual dispersal or from the viewed importance of reporting existing populations, especially in the temperate climate of northern States.

The recent recognition of possible novel species, $C$. largillierti and Corbicula sp. Form D, in North American waters may indicate the introduction of new founding populations of these taxa. Genetic analysis of additional populations throughout North America and from possible countries of origin will help to resolve this complex of Corbicula species and forms. A thorough genetic analysis of the genus is critical to understanding the risk associated with the recently identified taxa. The pathway of these new species introductions is unknown at the present time, but there are numerous possibilities. Identification of pathways and vectors is necessary before corrective action can be taken to prevent future introductions. These species or forms may well have a greater tolerance for lower temperatures or other biological and ecological characteristics that could make them more successful invaders and potentially result in even greater damage to aquatic ecosystems and the native freshwater mussel fauna. The need continues for monitoring Corbicula along with the investigation of its interactions with native mussels and other aquatic organisms.

\section{References Cited}

Angelo, R.T., Cringan, M.S., Hays, E., Goodrich, C.A., Miller, E.J., VanScoyoc, M.A., and Simmons, B.R., 2009, Historical changes in the occurrence and distribution of freshwater mussels in Kansas: Great Plains Research, v. 19, p. 89-126, accessed June 3, 2020, at https://digitalcommons.unl.edu/greatplainsresearch/990.

Araujo, R., Moreno, D., and Ramos, M.A., 1993, The Asiatic clam Corbicula fluminea (Muller, 1774) (BivalviaCorbiculidae) in Europe: American Malacological Bulletin, v. 10, p. 39-49, accessed April 25, 2020, at https://www.biodiversitylibrary.org/item/172621\#page/47/ mode/1up.

Atkinson, C.L., First, M.R., Covich, A.P., Opsahl, S.P., and Golladay, S.W., 2011, Suspended material availability and filtration-biodeposition processes performed by a native and invasive bivalve species in streams: Hydrobiologia, v. 667 , no. 1, p. 191-204, accessed November 19, 2020, at https://doi.org/10.1007/s10750-011-0640-5.

Atkinson, C.L., Opsahl, S.P., Covich, A.P., Golladay, S.W., and Conner, L.M., 2010, Stable isotopic signatures, tissue stoichiometry, and nutrient cycling $(\mathrm{C}$ and $\mathrm{N})$ of native and invasive freshwater bivalves: Journal of the North American Benthological Society, v. 29, no. 2, p. 496-505, accessed November 19, 2020, at https://doi.org/10.1899/09-083.1. 
Baker, R., Clarke, K., and Howlett, D., 1999, The Asiatic clam Corbicula fluminea (Müller) new to the UK: Transactions of the Norfolk and Norwich Naturalists' Society, v. 32, no. 1, p. 70-76, accessed April 20, 2020, at http://norfolknaturalists.org.uk/wp/wp-content/uploads/ 2017/04/TRN-1999-transactionsofno3211norf.pdf.

Barba-Macías, E., and Trinidad-Ocaña, C., 2017, New records of the exotic Asian clam Corbicula fluminea (Bivalvia: Veneroida: Cyrenidae) in wetlands of Papaloapan, Grijalva and Usumacinta basins: Revista Mexicana de Biodiversidad, v. 88, p. 450-453, accessed November 19, 2020, at https://doi.org/10.1016/j.rmb.2016.10.021.

Barnhart, M.C., Haag, W.R., and Roston, W.N., 2008, Adaptations to host infection and larval parasitism in Unionoida: Journal of the North American Benthological Society, v. 27, no. 2, p. 370-394, accessed November 19, 2020, at https://doi.org/10.1899/07-093.1.

Barrett, E.M., 1963, The California oyster industry: California Department of Fish and Game, Fish Bulletin 123, 103 p., accessed November 19, 2020, at https://escholarship.org/uc/ item $/ 1870 \mathrm{~g} 57 \mathrm{~m}$.

Beasley, C.R., Tagliaro, C.H., and Figueiredo, W.B., 2003, The occurrence of the Asian clam Corbicula fluminea in the lower Amazon basin: ACTA Amazonica, v. 33, no. 2, p. 317-323, accessed November 19, 2020, at https://www.scielo.br/pdf/aa/v33n2/1809-4392-aa-33-0200317.pdf.

Beaver, J.R., Crisman, T.L., and Brock, R.J., 1991, Grazing effects of an exotic bivalve (Corbicula fluminea) on hypereutrophic lake water: Lake and Reservoir Management v. 7, no. 1, p. 45-51, accessed November 19, 2020, at https://doi.org/10.1080/07438149109354253.

Belanger, S.E., Farris, J.L., Cherry, D.S., and Cairns, J., Jr., 1985, Sediment preferences of the freshwater Asiatic clam, Corbicula fluminea: Nautilus, v. 99, no. 2-3, p. 66-73, accessed April 25, 2020, at https://www.biodiversitylibrary.org/item/34230\#page/82/ mode/1up.

Belanger, T.V., Annis, C.G., Jr., and VanEpps, D.D., 1990, Growth rates of the Asiatic clam, Corbicula fluminea, in the upper and middle St. Johns River, Florida: Nautilus, v. 104, no. 1, p. 4-9, accessed November 19, 2020, at http://www.biodiversitylibrary.org/item/34802\#page/13/ mode/lup.

Benson, A.J., and Williams, J.D., 2021, Corbicula spp. locations in the United States from 1964 to 2019: U.S. Geological Survey data release, https://doi.org/10.5066/ P9JKHE3F.
Bequaert, J.C., and Miller, W.B., 1973, The mollusks of the arid Southwest with an Arizona check list: Tucson, Ariz., University of Arizona Press, 271 p.

Beran, L., 2000, First record of Corbicula fluminea (Mollusca-Bivalvia) in the Czech Republic: Acta Societatis Zoologicae Bohemicae, v. 64, no. 1, p. 1-2, accessed April 20, 2020, at http://www.zoospol.cz/ixadmin/ app/webroot/uploads/15-12-2017/2000/2000\%201.pdf.

Bespalaya, Y.V., Bolotov, I.N., Aksenova, O.V., Kondakov, A.V., Gofarov, M.Yu., Laenko, T.M., Sokolova, S.E., Shevchenko, A.R., and Travina, O.V., 2018, Aliens are moving to the Arctic frontiers-An integrative approach reveals selective expansion of androgenic hybrid Corbicula lineages towards the north of Russia: Biological Invasions, v. 20, p. 2227-2243, accessed November 19, 2020, at https://doi.org/10.1007/s10530-018-1698-z.

Bieler, R., Carter, J.G., and Coan, E.V., 2010, Part 2. Classification of bivalve families, in Bouchet, P., and Rocroi, J.-P., Nomenclator of bivalve families: Malacologia, v. 52, no. 2, p. 113-133, accessed November 19, 2020, at https://doi.org/10.4002/040.052.0201.

Bij de Vaate, A., and Greijdanus-Klaas, M., 1990, The Asiatic clam, Corbicula fluminea (Müller, 1774) (Pelecypoda, Corbiculidae), a new immigrant in the Netherlands: Bulletin Zoologisch Museum, Universiteit van Amsterdam, v. 12, no. 12, p. 173-178, accessed April 25, 2020, at https://pdfs.semanticscholar.org/ 1582/a1694e43a71b4832edc201d12017e880a7d4.pdf? ga $=2.264533702 .839907825 .1587825847$ 2036770349.1587825847.

Boltovskoy, D., Izaguirre, I., and Correa, N., 1995, Feeding selectivity of Corbicula fluminea (Bivalvia) on natural phytoplankton: Hydrobiologia, v. 312, p. 171-182, accessed November 19, 2020, at https://doi.org/10.1007/ BF00015510.

Britton, J.C., and Morton, B., 1979, Corbicula in North America-The evidence reviewed and evaluated, in Britton, J.C., Mattice, J.S., Murphy, C.E., and Newland, L.W., eds., Proceedings, First International Corbicula Symposium: Fort Worth, Tex., Texas Christian University Research Foundation Publication, p. 249-288.

Britton, J.C., and Morton, B., 1986, Polymorphism in Corbicula fluminea (Bivalvia - Corbiculoidea) from North America: Malacological Review, v. 19, p. 1-43.

Britton, J.C., and Murphy, C.E., 1977, New records and ecological notes for Corbicula manilensis in Texas: The Nautilus, v. 91, no. 1, p. 20-23, accessed April 25, 2020, at https://www.biodiversitylibrary.org/item/34214\#page/30/ mode/1up. 
Burch, B.L., 1978, Asian clam, Corbicula, threatens Hawaii: The Nautilus, v. 92, no. 1, p. 54-55, accessed April 25, 2020, at http://www.biodiversitylibrary.org/item/ 34218\#page/64/mode/1up.

Burch, J.Q., 1944, Check list of west North American marine mollusca from San Diego, California to Alaska: Minutes of the Conchological Club of Southern California, v. 38, p. 18.

Caffrey, J.M., Dick, J.T.A., Lucy, F.E., Davis, E., Niven, A., and Coughlan, N.E., 2016, First record of the Asian clam, Corbicula fluminea (Müller, 1774) (Bivalvia, Cyrenidae) in Northern Ireland: BioInvasions Records, v. 5, no. 4, p. 239-244, accessed November 19, 2020, at https://doi.org/ 10.3391/bir.2016.5.4.08.

California Department of Fish and Wildlife, 2009, California Non-native Estuarine and Marine Organisms Database (CalNEMO): California Department of Fish and Wildlife, Office of Spill Prevention and Response online database, accessed April 17, 2020, at https://wildlife.ca.gov/OSPR/Science/ Cal-NEMO.

Castaneda, R.A., Cvetanovska, E., Hamelin, K.M., Simard, M.A., and Ricciardi, A., 2018, Distribution, abundance and condition of an invasive bivalve (Corbicula fluminea) along an artificial thermal gradient in the St. Lawrence River: Aquatic Invasions, v. 13, no. 3, p. 379-392, accessed November 19, 2020, at https://doi.org/10.3391/ai.2018.13.3.06.

Chen, H., Zha, J., Liang, X., Bu, J., Wang, M., and Wang, Z., 2013, Sequencing and de novo assembly of the Asian clam (Corbicula fluminea) transcriptome using the Illumina GAIIx method: PLoS ONE, v. 8, no. 11, e79516, accessed November 19, 2020, at https://doi.org/10.1371/ journal.pone.0079516.

Chen, T.P., 1976, Aquaculture practices in Taiwan: Surrey, England, Fishing News (Books) Limited, 163 p., accessed November 19, 2020, at https://doi.org/10.1017/S0025315400021433.

Cherry, D.S., Scheller, J.L., Cooper, N.L., and Bidwell, J.R., 2005, Potential effects of Asian clam (Corbicula fluminea) die-offs on native freshwater mussels (Unionidae) I-Watercolumn ammonia levels and ammonia toxicity: Journal of the North American Benthological Society, v. 24, no. 2, p. 369-380, accessed November 19, 2020, at https://doi.org/ 10.1899/04-073.1.

Clarke, A.H., 1981, Corbicula fluminea, in Lake Erie: The Nautilus, v. 95, no. 2, p. 83-84, accessed April 25, 2020, at https://www.biodiversitylibrary.org/item/34791\#page/99/ mode/lup.
Clavero, M., Araujo, R.., Calzada, J., Delibes, M., Fernández, N., Gutiérrez-Expósito, C., Revilla, E., and Román, J., 2012, The first invasive bivalve in African fresh watersInvasion portrait and management options: Aquatic Conservation, Marine and Freshwater Ecosystems, v. 22, no. 2, p. 277-280, accessed November 19, 2020, at https://doi.org/10.1002/aqc.2231.

Clench, W.J., 1972, Corbicula manilensis (Philippi) in Oklahoma: The Nautilus, v. 85, no. 4, p. 145, accessed April 25, 2020, at https://www.biodiversitylibrary.org/item/ 34851\#page/171/mode/1up.

Cohen, R.R.H., Dresler, P.V., Phillips, E.J.P., and Cory, R.L., 1984, The effect of the Asiatic clam, Corbicula fluminea, on phytoplankton of the Potomac River, Maryland: Limnology and Oceanography, v. 29, no. 1, p. 170-180, accessed November 19, 2020, at https://doi.org/10.4319/ 1o.1984.29.1.0170.

Colwell, H., Ryder, J., Nuzzo, R., Reardon, M., Holland, R., and Wong, W.H., 2017, Invasive Asian clams (Corbicula fluminea) recorded from 2001 to 2016 in Massachusetts, USA: Management of Biological Invasions, v. 8, no. 4, p. 507-515, accessed November 19, 2020, at https://doi.org/ 10.3391/mbi.2017.8.4.05.

Cooper, N.L., Bidwell, J.R., and Cherry, D.S., 2005, Potential effects of Asian clam (Corbicula fluminea) die-offs on native freshwater mussels (Unionidae) II-Porewater ammonia: Journal of the North American Benthological Society, v. 24, no. 2, p. 381-394, accessed November 19, 2020, at https://doi.org/10.1899/04-074.1.

Cordeiro, J.R., and MacWilliams, S., 1999, Occurrence of the Asian clam, Corbicula fluminea (Müller, 1774) (Bivalvia: Sphaeriacea: Corbiculidae) in Colorado: Veliger, v. 42, p. 278-280, accessed April 25, 2020, at https:/www.biodiversitylibrary.org/item/134364\#page/296/ mode/1up.

Cordeiro, J.R., Olivero, A.P., and Sovell, J., 2007, Corbicula fluminea (Bivalvia: Sphaeriacea: Corbiculidae) in Colorado: Southwestern Naturalist, v. 52, no. 3, p. 424-430, accessed April 25, 2020, at https://doi.org/10.1894/00384909(2007)52[424:CFBSCI]2.0.CO;2.

Coughlan, N.E., Cuthbert, R.N., Dickey, J.W.E., Crane, K., Caffrey, J.M., Lucy, F.E., Davis, E., and Dick, J.T.A., 2019, Better biosecurity - Spread-prevention of the invasive Asian clam, Corbicula fluminea (Müller, 1774): Management of Biological Invasions, v. 10, no. 1, p. 111-126, accessed November 19, 2020, at https://doi.org/10.3391/ mbi.2019.10.1.07. 
Coughlan, N.E., Stevens, A.L., Kelly, T.C., Dick, J.T.A., and Jansen, M.A.K., 2017, Zoochorous dispersal of freshwater bivalves - An overlooked vector in biological invasions?: Knowledge and Management of Aquatic Ecosystems, v. 418, no. 42, 8 p., accessed November 19, 2020, at https://doi.org/10.1051/kmae/2017037.

Counts, C.L., III, 1981, Corbicula fluminea (Bivalvia: Sphaeriacea) in British Columbia: The Nautilus, v. 95, no. 1, p. 12-13, accessed April 25, 2020, at https:/www.biodiversitylibrary.org/item/34791\#page/22/ mode/1up.

Counts, C.L., III, 1985a, Corbicula fluminea (Bivalvia: Corbiculidae) in the State of Washington in 1937 and in Utah in 1978: The Nautilus, v. 99, no. 1, p. 18-19, accessed April 25, 2020, at http:/www.biodiversitylibrary.org/item/ 34230\#page/26/mode/1up.

Counts, C.L., III, 1985b, Distribution of Corbicula fluminea at nuclear facilities: Washington, D.C., U.S. Nuclear Regulatory Commission, $79 \mathrm{p}$.

Counts, C.L., III, 1986, The zoogeography and history of the invasion of the United States by Corbicula fluminea (Bivalvia: Corbiculidae), in Britton, J.C., and Prezant, R.S., eds., Proceedings of the Second International Corbicula Symposium, Little Rock, Arkansas, June 21-24, 1983: American Malacological Bulletin, Special Edition, no. 2., p. 7-39, accessed November 19, 2020, at https://www.biodiversitylibrary.org/bibliography/ 124975\#/summary.

Counts, C.L., III, 1991, Corbicula (Bivalvia: Corbiculidae)Part 1. Catalog of fossil and recent nominal species, Part 2. Compendium of zoogeographic records of North America and Hawaii, 1924-1984: Tryonia, v. 21, p. 1-134, accessed April 18, 2020, at https://www.biodiversitylibrary.org/item/ 246191\#page/253/mode/1up.

Counts, III, C.L., Villalaz, J.R., and Gómez H, J.A., 2003, Occurrence of Corbicula fluminea (Bivalvia: Corbiculidae) in Panama: Journal of Freshwater Ecology, v. 18, no. 3, p. 497-498, accessed November 19, 2020, at https://doi.org/ 10.1080/02705060.2003.9663986.

Covich, A.P., Dye, L.L, and Mattice, J.S., 1981, Crayfish predation on Corbicula under laboratory conditions: The American Midland Naturalist, v. 105, no. 1, p. 181-188, accessed November 22, 2020, at https://www.jstor.org/ stable/pdf/2425023.pdf.

Cowart, D.A., Renshaw, M.A., Gantz, C.A., Umek, J., Chandra, S., Egan, S.P., Lodge, D.M., and Larson, E.R., 2018, Development and field validation of an environmental DNA (eDNA) assay for invasive clams of the genus Corbicula: Management of Biological Invasions, v. 9, no. 1, p. 27-37, accessed November 19, 2020, at https://doi.org/ 10.3391/mbi.2018.9.1.03.
Csányi, B., 1999, Spreading invaders along the Danubian highway_First record of Corbicula fluminea (O. F. Müller, 1774) and C. fluminalis (O. F. Müller, 1774) in Hungary (Mollusca: Bivalvia): Folia Historico Naturalia Musei Matraensis, v. 23, p. 343-345, accessed April 26, 2020, at https://matramuzeum.nhmus.hu/sites/default/files/ nhmusfiles/kiadvanyok/folia/vol23/343-345.PDF.

Cummings, S.E., and Jones, J.A., 1978, Occurrence of Corbicula manilensis Phillipi in the lower Minnesota River: Journal of the Minnesota Academy of Science, v. 44, no. 3, p. 13-14.

Davis, J.R., 1980, Species composition and diversity of benthic macroinvertebrates in the upper Rio Grande, Texas: The Southwestern Naturalist, v. 25, no. 2, p. 137-150, accessed April 25, 2020, at https://doi.org/10.2307/3671236.

de Oliveira, C.R.C., Fugi, R., Brancalhão, K.P., and Agostinho, A.A., 2010, Fish as potential controllers of invasive mollusks in a neotropical reservoir: Brazilian Journal of Nature Conservation, v. 8, no. 2, p. 140-144, accessed November 19, 2020, at https://doi.org/10.4322/ natcon.00802006.

Denton, M.E., Chandra, S., Wittmann, M.E., Reuter, J., and Baguley, J.G., 2012, Reproduction and population structure of Corbicula fluminea in an oligotrophic subalpine lake: Journal of Shellfish Research, v. 31, no. 1, p. 145-152, accessed April 25, 2020, at https://www.fs.fed.us/psw/partnerships/tahoescience/ documents/p057_Denton2012.pdf.

Devick, W.S., 1991, Pattern of introductions of aquatic organisms to Hawaii freshwater habitats, in Devick, W.S., ed., New directions in research, management and conservations of Hawaiian freshwater stream ecosystems-Proceedings of the 1990 Freshwater Stream Biology and Fisheries Management Symposium: Honolulu, Hawaii, Hawaii Department of Land and Natural Resources, Division of Aquatic Resources, p. 189-213.

Diaz, R.J., 1974, Asiatic clam, Corbicula manilensis (Philippi), in the tidal James River, Virginia: Chesapeake Science, v. 15, no. 2, p. 118-120, accessed November 19, 2020, at https://doi.org/10.2307/1351273.

Domagala, J., Labecka, A.M., Pilecka-Rapacz, M., and Migdalska, B., 2004, Corbicula fluminea (O. F. Müller, 1774) (Bivalvia: Corbiculidae) - a species new to the Polish malacofauna: Folia Malacologica, v. 12, no. 3, p. 145-148, accessed April 25, 2020, at https://doi.org/10.12657/ folmal.012.011.

Douglass, S., Reasor, E., Tiemann, J., Stodola, A., McMurray, S., and Poulton, B., 2020, Recent evaluation of Corbicula Form D distribution in the Midwest, U.S.A.: The American Midland Naturalist, v. 183, no. 1, p. 136-142. 
Dreier, H., and Tranquilli, J.A., 1981, Reproduction, growth, distribution and abundance of Corbicula in an Illinois cooling lake, in Larimore, R.W., and Tranquilli, J.A., eds., The Lake Sangchris study - Case history of an Illinois cooling lake: Illinois Natural History Survey Bulletin, v. 32, no. 4, p. 378-393, accessed April 25, 2020, at http://hdl.handle.net/2142/44056.

Dresler, P.V., and Cory, R.L., 1980, The Asiatic clam, Corbicula fluminea (Müller), in the tidal Potomac River, Maryland: Estuaries, v. 3, no. 2, p. 150-151, accessed November 19, 2020, at https://doi.org/10.2307/1351560.

Duke Power Company, 1983, Final environmental statement related to the operation of Catawba Nuclear Station, units 1 and 2, dockets nos. 50-413 and 50-414, NUREG-0921: Washington, D.C., U.S. Nuclear Regulatory Commission, Office of Nuclear Reactor Regulation report NUREG-0921, accessed April 25, 2020, at https://inis.iaea.org/search/ search.aspx?orig_q=RN:14769489.

Dundee, D.S., and Dundee, H.A., 1958, Extensions of known ranges of 4 mollusks: The Nautilus, v. 72 , no. 2, p. 51-53, accessed April 24, 2020, at https://www.biodiversitylibrary.org/item/34875\#page/73/ mode/1up.

Dundee, D.S., and Harman, W.J., 1963, Corbicula fluminea (Müller) in Louisiana: The Nautilus, v. 77, no. 1, p. 30, accessed April 24, 2020, at https://www.biodiversitylibrary.org/item/34871\#page/48/ mode/1up.

Eckblad, J.W., 1975, The Asian clam Corbicula in the upper Mississippi River: The Nautilus, v. 89, no. 1, p. 4, accessed April 24, 2020, at https://www.biodiversitylibrary.org/item/ 55104\#page/10/mode/1up.

Eng, L.L., 1979, Population dynamics of the Asiatic clam, Corbicula fluminea (Müller), in the concrete-lines DeltaMendota Canal of central California, in Britton, J.C., Mattice, J.S., Murphy, C.E., and Newland, L.W., eds., Proceedings-First International Corbicula Symposium, Fort Worth, Texas, October 13-15, 1977: Fort Worth, Tex., Texas Christian University Research Foundation Publication, p. 39-68.

Evans, L.P., Jr., Murphy, C.E., Britton, J.C., and Newland, L.W., 1979, Salinity relationships in Corbicula fluminea (Muller), in Britton, J.C., Mattice, J.S., Murphy, C.E., and Newland, L.W., eds., Proceedings-First International Corbicula Symposium, Fort Worth, Texas, October 13-15, 1977: Fort Worth, Tex., Texas Christian University Research Foundation Publication, p. 193-214.

Fechtner, F.R., 1962, Corbicula fluminea (Müller) from the Ohio River: The Nautilus, v. 75, no. 3, p. 126, accessed April 25, 2020, at https://www.biodiversitylibrary.org/item/ 34252\#page/150/mode/1up.
Fernández, A., Vega, A., Maceira, D., Reynaldo, E., Tejeda, C.R., Córdova, E., and Pavón, H., 2015, Estado de la Almeja asiática Corbicula fluminea (Bivalvia: Corbiculidae) en la Región Oriental de Cuba, En-X Convención Internacional sobre Medio Ambiente y Desarrollo, Memorias, Palacio de las Convenciones de la Habana, Cuba, 6 al 10 de julio del 2015: CVMEB V Congreso Manejo de Ecosistemas y Biodiversidad, EB-173, 12 p., accessed April 25, 2020, at https://www.researchgate.net/ scientific-contributions/2090638205_Carmen_R_Tejeda.

Ferreira-Rodríguez, N., 2019, Spatial aggregation of native with non-native freshwater bivalves and activity depletion under summer heat waves- 'Dangerous liaisons' in a climate change context: Hydrobiologia, v. 834, p. 75-85, accessed November 19, 2020, at https://doi.org/10.1007/ s10750-019-3910-2.

Ferreira-Rodríguez, N., Fandiño, L., Pedreira, A., and Pardo, I., 2018a, First evidence of asymmetric competition between the non-native clam Corbicula fluminea and native freshwater mussel Unio delphinus during a summer heat wave: Aquatic Conservation, Marine and Freshwater Ecosystems, v. 28, no. 5, p. 1105-1113, accessed November 19, 2020, at https://doi.org/10.1002/aqc.2964.

Ferreira-Rodríguez, N., Sousa, R., and Pardo, I., 2018b, Negative effects of Corbicula fluminea over native freshwater mussels: Hydrobiologia, v. 810, no. 1, p. 85-95, accessed April 25, 2020, at https://doi.org/10.1007/s10750016-3059-1.

Ferreira-Rodríguez, N., and Pardo, I., 2017, The interactive effects of temperature, trophic status, and the presence of an exotic clam on the performance of a native freshwater mussel: Hydrobiologia, v. 797, p. 171-182, November 19, 2020, at https://doi.org/10.1007/s10750-017-3170-y.

Filice, F.P., 1958, Invertebrates in the estuarine portion of San Francisco Bay and some factors influencing their distributions: Wasmann Journal of Biology, v. 16, no. 2, p. 159-211, accessed April 25, 2020, at https://igitalcollections.usfca.edu/digital/collection/ p15129coll11/id/288.

Fitch, J.E., 1953, Letter from John E. Fitch of the California Game and Fish to Mr. [Dr. John Q.] Burch: Minutes of the Conchological Society of Southern California, v. 130 (August), p. 9-10, accessed November 19, 2020, at https://www.biodiversitylibrary.org/item/180113\#page/127/ mode/1up. 
Foe, C., and Knight, A., 1986, A thermal energy budget for juvenile Corbicula fluminea, in Britton, J.C., and Prezant, R.S., eds., Proceedings of the Second International Corbicula Symposium, Little Rock, Arkansas, June 21-24, 1983: Hattiesburg, Miss., American Malacological Bulletin Special Edition, no. 2, p. 143-151, accessed November 19, 2020, at https://www.biodiversitylibrary.org/bibliography/ $124975 \# /$ summary.

Foehrenbach, J., and Raeihle, D., 1984, A further range extension of the Asiatic clam: New York Fish and Game Journal, v. 31 , no. 2, p. 224-226.

Forrest, A.L., Andradóttir, H.Ó., Mathis, T.J., Wittmann, M.E., Reuter, J.E., and Schladow, S.G., 2017, Passive transport of a benthic bivalve (Corbicula fluminea) in large lakesImplications for deepwater establishment of invasive species: Hydrobiologia, v. 797, no.1, p. 87-102, accessed November 19, 2020, at https://doi.org/10.1007/s10750017-3162-y.

Forrest, A.L., Wittmann, M.E., Schmidt, V., M.E., Raineault, N.A., Hamilton, A., Pike, W., Schladow, S.G. Reuter, J.E., Laval, B.E., and Trembanis, A.C., 2012, Quantitative assessment of invasive species in lacustrine environments through benthic imagery analysis: Limnology and Oceanography, v. 10, p. 65-74, accessed November 19, 2020, at https://doi.org/10.4319/lom.2012.10.65.

Fox, R.O., 1970, Corbicula in Baja California: The Nautilus, v. 83, no. 4, p. 145, accessed April 25, 2020, at https://www.biodiversitylibrary.org/item/34847\#page/167/ mode/1up.

Fox, R.O., 1971a, The Corbicula story-Chapter two. Abstracts and Proceedings of the Third Annual Meeting Western Society of Malacologists, Stanford, California, June 24-27, 1970: Echo 3, Publication of the Western Society of Malacologists, p. 23, accessed November 19, 2020, at https://www.biodiversitylibrary.org/item/ 100305\#page/163/mode/1up.

Fox, R.O., 1971b, The Corbicula story-Chapter three. Abstracts and Proceedings of the Fourth Annual Meeting of the Western Society of Malacologists, Pacific Grove, California, June 16-19, 1971: Echo 4, Publication of the Western Society of Malacologists, p. 20, accessed November 19, 2020, at https://www.biodiversitylibrary.org/ item/100305\#page/242/mode/1up.

Freeman, P.W., and Perkins, K., 1992, Survey of mollusks of the Platte River-Final report: Grand Island, Nebr., U.S. Fish and Wildlife Service, 27 p., accessed November 19, 2020, at https://digitalcommons.unl.edu/cgi/ viewcontent.cgi article $=1025 \&$ context $=$ natrespapers.
French III, J.R.P., 1993, How well can fishes prey on zebra mussels in eastern North America?: Fisheries, v. 18, no. 6, p. 13-19, accessed November 19, 2020, at https://doi.org/ 10.1577/1548-8446(1993)018<0013:HWCFPO>2.0.CO;2.

Fuller, S.L.H., 1978, Fresh-water mussels (Mollusca: Bivalvia: Unionidae) of the upper Mississippi River: Philadelphia, Pa., Academy of Natural Sciences of Philadelphia, 401 p.

Fuller, S.L.H., and Powell, C.E., Jr., 1973, Range extensions of Corbicula manilensis (Philippi) in the Atlantic drainage of the United States: The Nautilus, v. 87, no. 2, p. 59, accessed April 25, 2020, at https://www.biodiversitylibrary.org/item/ 34829\#page/73/mode/1up.

Gainey, L.F., Jr., and Greenberg, M.J., 1977, Physiological basis of the species abundance-salinity relationship in molluscs-A speculation: Marine Biology, v. 40, no. 1, p. 41-49, accessed November 19, 2020, at https://doi.org/ 10.1007/BF00390626.

Gama, M., Crespo, D., Dolbeth, M., and Anastácio, P., 2016, Predicting global habitat for Corbicula fluminea using species distribution models - The importance of different environmental datasets: Ecological Modelling, v. 319, p.163-169, accessed November 19, 2020, at https://doi.org/ 10.1016/j.ecolmodel.2015.06.001.

Gama, M., Crespo, D., Dolbeth, M., and Anastácio, P.M., 2017, Ensemble forecasting of Corbicula fluminea worldwide distribution-Projections of the impact of climate change: Aquatic Conservation, Marine and Freshwater Ecosystems, v. 27, p. 675-684, accessed November 19, 2020, at https://doi.org/10.1002/aqc. 2767.

Gardner, J.A., Jr., Woodall, W.R., Jr., Staats, A.A., Jr., and Napoli, J.F., 1976, The invasion of the Asiatic clam (Corbicula manilensis) in the Altamaha River, Georgia: The Nautilus, v. 90, no. 3, p. 117-125, accessed April 25, 2020, at https://www.biodiversitylibrary.org/item/34228\#page/ 139/mode/1up.

Gatlin, M.R., Shoup, D.E., and Long, J. M., 2013: Invasive zebra mussels (Dreissena polymorpha) and Asian clams (Corbicula fluminea) survive gut passage of migratory fish species-Implications for dispersal: Biological Invasions, v. 15, p. 1195-1200, accessed November 19, 2020, at https://doi.org/10.1007/s10530-012-0372-0.

GBIF.org, 2020, GBIF occurrence: Global Biodiversity Information Facility Occurrence download, accessed June 10, 2020, at https://doi.org/10.15468/dl.wpp53e.

Green, A.J., and Figuerola, J., 2005, Recent advances in the study of long-distance dispersal of aquatic invertebrates via birds: Diversity and Distributions, v. 11, no. 2, p. 149-156, accessed November 19, 2020, at https://doi.org/10.1111/ j.1366-9516.2005.00147.x. 
Haag, W.R., 2012, North American freshwater musselsNatural history, ecology, and conservation: New York, Cambridge University Press, 505 p. [Also available at https://doi.org/10.1017/CBO9781139048217.]

Haag, W.R., 2019, Reassessing enigmatic mussel declines in the United States: Freshwater Mollusk Biology and Conservation, v. 22, no. 2, p. 43-60, accessed November 19, 2020, at https://doi.org/10.31931/fmbc.v22i2.2019.43-60.

Hakenkamp, C.C., and Palmer, M.A., 1999, Introduced bivalves in freshwater ecosystems-The impact of Corbicula on organic matter dynamics in a sandy stream: Oecologia, v. 119, no. 3, p. 445-451, accessed April 25, 2020, at https://doi.org/10.1007/s004420050806.

Hakenkamp, C.C., Ribblett, S.G., Palmer, M.A., Swan, C.M., Reid, J.W., and M.R. Goodison, M.R., 2001, The impact of an introduced bivalve (Corbicula fluminea) on the benthos of a sandy stream: Freshwater Biology, v. 46, no. 4, p. 491-501, accessed November 19, 2020, at https://doi.org/ 10.1046/j.1365-2427.2001.00700.x.

Hanna, G.D., 1966, Introduced mollusks of western North America: Occasional Papers of the California Academy of Sciences, v. 48, p. 1-108, accessed April 25, 2020, at https://www.biodiversitylibrary.org/item/22420\#page/7/ mode/1up.

Haponski, A.E., and Ó Foighil, D., 2019, Phylogenomic analyses confirm a novel invasive North American Corbicula (Bivalvia: Cyrenidae) lineage: PeerJ, v. 7, e7484, accessed November 19, 2020, at https://doi.org/10.7717/peerj.7484.

Hassett, W., Bollens, S.M., Counihan, T.D., RollwagenBollens, G., Zimmerman, J., and F.E. Emerson, F.E., 2017, Veligers of the invasive Asian clam Corbicula fluminea in the Columbia River Basin-Broadscale distribution, abundance, and ecological associations: Lake and Reservoir Management, v. 33, no. 3, p. 234-248, accessed November 19, 2020, at https://doi.org/10.1080/ 10402381.2017.1294218.

Hawaii Department of Agriculture, 2006, List of prohibited animals: Honolulu, Hawaii, Hawaii Department of Agriculture, 12 p., accessed April 14, 2020, https://hdoa.hawaii.gov/pi/files/2012/12/AR-71P.pdf.

Hillis, D.M., and Patton, J.C., 1982, Morphological and electrophoretic evidence for two species of Corbicula (Bivalvia: Corbiculidae) in North America: The American Midland Naturalist v. 108, no. 1, p. 74-80, accessed November 19, 2020, at https://doi.org/10.2307/2425294.
Holm, G.P., 2014, Results of a visual survey of the lower Fraser River for the Asian clam, Corbicula fluminea Müller, 1774: Dredgings, v. 54, no. 5, p. 3-5, accessed April 25, 2020, at http:/www.bily.com/pnwsc/web-content/Articles/ Results-of-a-visual-survey-of-the-lower-Fraser-River-forthe-Asian-Clam.pdf.

Horning, W.B., and Keup, L., 1964, Decline of Asiatic clam in Ohio River: The Nautilus, v. 78, no. 1, p. 29-30, accessed April 25, 2020, at https://www.biodiversitylibrary.org/item/ 34877\#page/43/mode/1up.

Howells, R.G., 1999, Guide to identification of harmful and potentially harmful fishes, shellfishes, and aquatic plants prohibited in Texas (revised): Austin, Tex., Texas Parks and Wildlife Department, Inland Fisheries Division, 370 p., accessed April 18, 2020, at https://tpwd.texas.gov/ publications/landwater/water/\#exotic.

Howells, R.G., Wise, J.B., Karatayev, A.Y., and Burlakova, L.E., 2004, New "old records" of Asian clam Corbicula fluminea in Texas: Ellipsaria, v. 6, no. 3, p. 11, accessed November 19, 2020, at https://molluskconservation.org/ PUBLICATIONS/ELLIPSARIA/Ellipsaria2004_63.pdf.

Hubenov, Z., 2001, Corbiculidae-A new family for the Bulgarian recent malacofauna (Mollusca: Bivalvia): ACTA Zoologica Bulgarica, v. 53, no. 3, p. 61-66, accessed November 19, 2020, at https://pdfs.semanticscholar.org/ 25a4/c4afcfedf2bbd3762ac37dcdd3193cac129e.pdf.

Ilarri, M., Antunes C., Guilhermino, L., and Sousa R., 2011, Massive mortality of the Asian clam Corbicula fluminea in a highly invaded area: Biological Invasions, v. 13, p. 277-280, accessed November 19, 2020, at https://doi.org/ 10.1007/s10530-010-9833-5.

Ilarri, M.I., Souza, A.T., Antunes, C., Guilhermino, L., and Sousa, R., 2014, Influence of the invasive Asian clam Corbicula fluminea (Bivalvia: Corbiculidae) on estuarine epibenthic assemblages: Estuarine, Coastal and Shelf Science, v. 143, p. 12-19, accessed November 19, 2020, at https://doi.org/10.1016/j.ecss.2014.03.017.

Ingram, W.M., 1959, Asiatic clams as potential pests in California water supplies: Journal American Water Works Association, v. 51, no. 3, p. 363-370, accessed April 26, 2020, at https://doi.org/10.1002/j.15518833.1959.tb15750.x.

Illinois Natural History Survey, 2019, Illinois Natural History Survey mollusks collection: Champaign, Ill., Illinois Natural History Survey online database, accessed May 8, 2020, at https://mollusk.inhs.illinois.edu/. 
Isom, B.G., 1986, Historical review of Asiatic clam (Corbicula) invasion and biofouling of waters and industries in the Americas, in Britton, J.C., and Prezant, R.S., eds., Proceedings of the Second International Corbicula Symposium, Little Rock, Arkansas, June 21-24, 1983: Hattiesburg, Miss., American Malacological Bulletin Special Edition, no. 2, p. 1-5, accessed November 19, 2020, at https://www.biodiversitylibrary.org/bibliography/ $124975 \# /$ summary.

Ituarte, C.F., 1994, Corbicula and Neocorbicula (Bivalvia: Corbiculidae) in the Paraná, Uruguay, and Río de La Plata basins: The Nautilus, v. 107, no. 4, p. 129-135, accessed April 25, 2020, at https://www.biodiversitylibrary.org/item/ 34790\#page/153/mode/1up.

Janech, M.G., and Hunter, R.D., 1995, Corbicula fluminea in a Michigan River-Implication for low temperature tolerance: Malacological Review, v. 28, p. 119-124.

Karatayev, A.Y., Howells, R.G., Burlakova, L.E., and Sewell, B.D., 2005, History of spread and current distribution of Corbicula fluminea (Müller) in Texas: Journal of Shellfish Research, v. 24, no. 2, p. 553-559, accessed November 19, 2020, at https://doi.org/10.2983/07308000(2005)24[553:HOSACD]2.0.CO;2.

Karatayev, A.Y., Padilla, D.K., Minchin, D., Boltovskoy, D., and Burlakova, L.E., 2007, Changes in global economies and trade- The potential spread of exotic freshwater bivalves: Biological Invasions, v. 9, no. 2, p. 161-180, accessed November 19, 2020, at https://doi.org/10.1007/ s10530-006-9013-9.

Keup, L., Horning, W.B., and Ingram, W.M., 1963, Extension of range of the Asiatic clam to Cincinnati reach of the Ohio River: The Nautilus, v. 77, no. 1, p. 18-21, accessed April 25, 2020, at https://www.biodiversitylibrary.org/item/ 34871\#page/34/mode/1up.

Kinzelbach, R., 1991, Die Körbchenmuscheln Corbicula fluminalis, Corbicula fluminea und Corbicula fuviatilis in Europa (Bivalvia: Corbiculidae): Mainzer Naturwissenschaftliches Archiv, v. 29, p. 215-228.

Kirkendale, L., and Clare, J., 2008, The Asiatic clam (Corbicula fluminea) "rediscovered" on Vancouver Island: Victoria Naturalist, v. 65, no. 3, p. 12-16, accessed April 26, 2020, at https://www.vicnhs.bc.ca/Naturalist/VNHS2008/ The $\% 20$ Victoria $\% 20$ Naturalist $\% 20 \% 20-\% 202008 \% 20$ $\% 2011 \% 2 \mathrm{C} 12 \% 20 \mathrm{Vol} \% 2065 \% 20 \mathrm{No} \% 2003$.pdf.

Kraemer, L.R., 1978, Corbicula fluminea (Bivalvia: Sphaeriacea) - The functional morphology of its hermaphroditism: Bulletin of the American Malacological Union, v. 1978, p. 40-49, accessed May 7, 2020, at https://www.biodiversitylibrary.org/item/217531\#page/182/ mode/1up.
Kraemer, L.R., 1979, Corbicula (Bivalvia: Sphaeriacea) vs. indigenous mussels (Bivalvia: Unionacea) in U.S. rivers-A hard case for interspecific competition?: American Zoologist, v. 19, no. 4, p. 1085-1096, accessed April 26, 2020, at https://doi.org/10.1093/icb/19.4.1085.

Kraemer, L.R., and Galloway, M.L., 1986, Larval development of Corbicula fluminea (Müller) (Bivalvia: Corbiculacea)_-An appraisal of its heterochrony: American Malacological Bulletin, v. 4, p. 61-79, accessed May 7, 2020, at https:/www.biodiversitylibrary.org/item/ 172620\#page/69/mode/1up.

Kreiser, B.R., and Mitton, J.B., 1995, The evolution of cold tolerance in Corbicula fluminea (Bivalvia: Corbiculidae): The Nautilus, v. 109, no. 4, p. 111-112, accessed April 25, 2020, at https://www.biodiversitylibrary.org/item/ 34220\#page/135/mode/1up.

Lake George Park Commission, 2016, 2016 Lake George Asian clam lakewide survey-Final report: Lake George, N.Y., Lake George Park Commission, 4 p., accessed May 8, 2018, at https://www.lakegeorgeassociation.org/news-andevents/publications/.

Lake George Park Commission, 2017, 2017 Lake George Asian clam lakewide survey-Final report: Lake George, N.Y., Lake George Park Commission, 5 p., accessed May 8, 2018, at https://www.lakegeorgeassociation.org/news-andevents/publications/.

Lake George Park Commission, 2019, 2019 Lake George Asian clam lakewide survey-Final report: Lake George, N.Y., Lake George Park Commission, 5 p., accessed May 8, 2018, at https://www.lakegeorgeassociation.org/news-andevents/publications/.

Lauritsen, D.D., and Mozley, S.C., 1989, Nutrient excretion by the Asiatic clam Corbicula fluminea: Journal of the North American Benthological Society, v. 8, no. 2, p. 134-139, accessed November 19, 2020, at https://doi.org/ $10.2307 / 1467631$.

Lavoie, R.E., 2005, Oyster culture in North AmericaHistory, present and future-The 1st International Oyster Symposium Proceedings, July 13-15 in Tokyo, Japan: Oyster Research Institute News, v. 2005, no.17, 9 p., accessed November 19, 2020, at https://worldoyster.org/wp/ wp-content/uploads/2019/04/news_17e.pdf.

Lawrence, S.J., and Seiler, R.L., 2002, Physical data and biological data for algae, aquatic invertebrates, and fish from selected reaches on the Carson and Truckee rivers, Nevada and California, 1993-97: U.S. Geological Survey Open-File Report 02-012, 8 p. plus appendixes, at https://pubs.usgs.gov/of/2002/ofr02-012/. 
Layhee, M., Yoshioka, M., Farokhkish, B., Gross, J.A., and Sepulveda, A.J., 2014, Toxicity of a traditional molluscicide to Asian clam veligers: Journal of Fish and Wildlife Management, v. 5, no. 1, p. 141-145, accessed November 19, 2020, at https://doi.org/10.3996/042013JFWM-032.

Lee, T., Siripattrawan, S., Ituarte, C.F., and Ó Foighil, D., 2005, Invasion of the clonal clams - Corbicula lineages in the New World: American Malacological Bulletin, v. 20, nos. 1-2, p. 113-122, accessed April 26, 2020, at https://www.researchgate.net/publication/228746138 Invasion_of_the_clonal_clams_Corbicula_lineages_in the New_World.

Leff, L.G., Burch, J.L., and McArthur, J.V., 1990, Spatial distribution, seston removal, and potential competitive interactions of the bivalves Corbicula fluminea and Elliptio complanata, in a coastal plain stream: Freshwater Biology, v. 24 , no. 2, p. 409-416, accessed November 19, 2020, at https://doi.org/10.1111/j.1365-2427.1990.tb00720.x.

Lopes-Lima, M., Sousa, R., Geist, J., and 46 others, 2017, Conservation status of freshwater mussels in Europe-State of the art and future challenges: Biological Reviews, v. 92, p. 572-607, accessed November 19, 2020, at https://doi.org/ 10.1111/brv.12244.

López, E., Garrido-Olvera, L., Benavides-González, F., Blanco-Martinez, Z., Pérez-Castañeda, R., SánchezMartinez, J.G., Correa-Sandoval, A., Vázquez-Sauceda, M.L., and Rábago-Castro, J.L., 2019, New records of invasive mollusks Corbicula fluminea (Müller, 1774), Melanoides tuberculata (Müller, 1774) and Tarebia granifera (Lamarck, 1816) in the Vicente Guerrero Reservoir, Mexico: BioInvasions Records, v. 8, no. 3, p. 640-652, accessed November 19, 2020, at https://doi.org/ 10.3391/bir.2019.8.3.21.

López-López, E., Sedeño-Díaz, J.E., Vega, P.T., and Oliveros, E., 2009, Invasive mollusks Tarebia granifera Lamarck, 1822 and Corbicula fluminea Müller, 1774 in the Tuxpam [Tuxpan] and Tecolutla rivers, Mexico-Spatial and seasonal distribution patterns: Aquatic Invasions, v. 4, no. 3, p. 435-450, accessed November 19, 2020, at http://aquaticinvasions.net/2009/AI_2009_4_3_Lopez_ etal.pdf.

Mack, R.N., Simberloff, D., Lonsdale, W.M., Evans, H., Clout, M., and Bazzaz, F., 2000, Biotic invasions: causes, epidemiology, global consequences, and control: Ecological Applications v.10, no. 3, p. 689-710, accessed December 10, 2020, at https://doi.org/10.1890/10510761(2000)010[0689:BICEGC]2.0.CO;2.

Mackie, G.L., and Claudi, R., 2010, Monitoring and control of macrofouling mollusks in fresh water systems: Boca Raton, Fla., CRC Press, Taylor Francis Group, 507 p.
Mackie, G.L., and Huggins, D.G., 1983, Sphaeriacean clams of Kansas: Lawrence, Kans., University of Kansas, Technical Publications of the State Biological Survey of Kansas, 92 p., at https://www.researchgate.net/publication/ 289126398_Sphaeriacean_clams_of_Kansas.

Majdi, N., Bardon, L., and Gilbert, F., 2014, Quantification of sediment reworking by the Asiatic clam Corbicula fluminea Müller, 1774: Hydrobiologia, v. 732, p. 85-92, accessed November 19, 2020, at https://doi.org/10.1007/s10750014-1849-x.

Marescaux, J., Falisse, E., Lorquet, J., Van Donick, K., Beisel, J., and Descy, J., 2016, Assessing filtration rates of exotic bivalves-Dependence on algae concentration and seasonal factors: Hydrobiologia, v. 777, p. 67-78, accessed November 19, 2020, at https://doi.org/10.1007/s10750016-2764-0.

Mason, W.T., and Clugston, J.P., 1993, Foods of the Gulf sturgeon in the Suwanee River, Florida: Transactions of the American Fisheries Society, v. 122, p. 378-385, accessed November 19, 2020, at https://doi.org/10.1577/15488659(1993)122<0378:FOTGSI $>2.3 . C O ; 2$.

Mattice, J.S., 1977, Interaction of Corbicula sp. with power plants: Oak Ridge, Tenn., Oak Ridge National Laboratory, 31 p., accessed November 19, 2020, at https://digital.library.unt.edu/ark:/67531/metadc1061386/ m2/1/high_res_d/5065476.pdf.

Mattice, J.S., and Dye, L.L., 1975, Temperature tolerance of the adult Asiatic clam Corbicula manilensis (Mollusca: Bivalvia): Oak Ridge, Tenn., Oak Ridge National Laboratory report CONF-750425-5, 17 p., accessed November 19, 2020, at https://digital.library.unt.edu/ark:/ 67531/metadc1025604/m2/1/high_res_d/4214331.pdf.

McCabe, G.T., Emmett, R.L., and Hinton, S.S., 1993, Feeding ecology of juvenile white sturgeon (Acipenser transmontanus) in the lower Columbia River: Northwest Science, v. 67, p. 170-180, accessed November 19, 2020, at https://research.libraries.wsu.edu/xmlui/bitstream/ handle/2376/1588/v67\%20p170\%20McCabe\%20Jr.\%20 et $\% 20$ al.PDF? sequence=1.

McDowell, W.G., Benson, A.J., and Byers, J.E., 2014, Climate controls the distribution of a widespread invasive speciesImplications for future range expansion: Freshwater Biology, v. 59, no. 4, p. 847-857, accessed November 19, 2020, at https://doi.org/10.1111/fwb.12308.

McDowell, W.G., McDowell, W.H., and Byers, J.E., 2017, Mass mortality of a dominant invasive species in response to an extreme climate event-Implications for ecosystem function: Limnology and Oceanography, v. 62 , p. 177-188, accessed November 19, 2020, at https://aslopubs.onlinelibrary.wiley.com/doi/full/10.1002/ lno.10384. 
McLeod, M.J., and Sailstad, D.M., 1980, An electrophoretic study of Corbicula fluminea (Bivalvia:Corbiculidae) in the Catawba River: Bulletin of the American Malacological Union, v. 1980, p. 17-19, accessed May 7, 2020, at https://www.biodiversitylibrary.org/item/217531\#page/357/ mode/1up.

McMahon, R.F., 1982, The occurrence and spread of the introduced Asiatic freshwater bivalve, Corbicula fluminea (Müller) in North America: The Nautilus, v. 96, no. 4, p. 134-141, accessed April 25, 2020, at http://www.biodiversitylibrary.org/item/34793\#page/156/ mode/1up.

McMahon, R.F., 1983, Ecology of an invasive pest bivalve, Corbicula, in Russell-Hunter, W.D., ed., The Mollusca, volume 6-Ecology: New York, Academic Press, Inc., p. 505-561, accessed November 19, 2020, at https://doi.org/ 10.1016/C2013-0-11706-0.

McMahon, R.F., 1991, Mollusca-Bivalvia, in Thorp, J.H., and Covich, A.P., eds., Ecology and classification of North American freshwater invertebrates: San Diego, Calif., Academic Press, Inc., p. 315-399.

McMahon, R.F., 2000, Invasive characteristics of the freshwater bivalve Corbicula fluminea, in Claudi, R., and Leach, J.H., eds., Nonindigenous freshwater organisms vectors, biology, and impacts: Boca Raton, Fla, Lewis Publishers, p. 315-343.

McMahon, R.F., and Williams, C.J., 1986, Growth, life cycle, upper thermal limit and downstream colonization rates in a natural population of the freshwater bivalve, Corbicula fluminea (Muller) receiving thermal effluents, in Britton, J.C., and Prezant, R.S., eds., Proceedings of the Second International Corbicula Symposium, Little Rock, Arkansas, June 21-24, 1983: American Malacological Bulletin Special Edition, no. 2., p. 231-239, accessed November 19, 2020, at https://www.biodiversitylibrary.org/bibliography/ $124975 \# /$ summary.

Metcalf, A.L., 1966, Corbicula manilensis in the Mesilla Valley of Texas and New Mexico: The Nautilus, v. 80 , no. 1, p. 16-20, accessed April 25, 2020, at https://www.biodiversitylibrary.org/item/34862\#page/34/ mode/1up.

Midwest Invasive Species Information Network (MISIN), 2019, Midwest Invasive Species Information Network: East Lansing, Mich., Michigan State University online database, accessed July 15, 2019, at https://www.misin.msu.edu.

Milera, J.F., and Quiros, A., 1995., Corbicula manilensis (Mollusca: Bivalvia: Corbiculidae) en Cuba: Cocuyo, v. 2, p. 10, accessed May 7, 2020, at http://repositorio.geotech.cu/xmlui/handle/1234/1294.
Minchin, D. and Boelens, R., 2018, Natural dispersal of the introduced Asian clam Corbicula fluminea (Müller, 1774) (Cyrenidae) within two temperate lakes: BioInvasions Records, v. 7, no. 3, p. 259-268, accessed November 19, 2020, at https://doi.org/10.3391/bir.2018.7.3.06.

Minckley, W.L., 1982, Trophic interrelations among introduced fishes in the lower Colorado River, southwestern United States: California Fish and Game, v. 68, p. 78-89, accessed June 29, 2020, at http://www.nativefishlab.net/ library/textpdf/13692.pdf.

Modesto, V., Castro, P., Lopes-Lima, M., Antunes, C., Ilarri, M., and Sousa, R., 2019, Potential impacts of the invasive species Corbicula fluminea on the survival of glochidia: Science of the Total Environment, v. 673, p. 157-164, accessed November 19, 2020, at https://doi.org/10.1016/ j.scitotenv.2019.04.043.

Morgan, D.E., Keser, M., Swenarton, J.T., and Foertch, J.F., 2003, Population dynamics of the Asiatic clam, Corbicula fluminea (Müller) in the lower Connecticut River-Establishing a foothold in New England: Journal of Shellfish Research, v. 22, no. 1, p. 193-203, accessed May 7, 2020, at https://www.biodiversitylibrary.org/item/ 22242\#page/199/mode/1up.

Morton, B., 1979a, Corbicula in Asia, in Britton, J.C., Mattice, J.S., Murphy, C.E., and Newland, L.W., eds., Proceedings, First International Corbicula Symposium, Fort Worth, Texas, October 13-15, 1977: Fort Worth, Tex., Texas Christian University Research Foundation Publication, p. $15-38$.

Morton, B., 1979b, Freshwater fouling bivalves, in Britton, J.C., Mattice, J.S., Murphy, C.E., and Newland, L.W., eds., Proceedings, First International Corbicula Symposium, Fort Worth, Texas, October 13-15, 1977: Fort Worth, Tex., Texas Christian University Research Foundation Publication, p. 1-14.

Mouthon, J., 1981, Sur la présence en France et au Portugal de Corbicula (Bivalvia, Corbiculidae) originaire d'Asie: Basteria, v. 45, p. 109-116, accessed April 26, 2020, at https://natuurtijdschriften.nl/search?identifier $=596744$.

Müeller, O., and Baur, B., 2011, Survival of the invasive clam Corbicula fluminea (Müller) in response to winter water temperature: Malacologia, v. 53, no. 2, p. 367-371, accessed November 19, 2020, at https://doi.org/10.4002/ 040.053.0207.

Munjiu, O., and Shubernetski, I., 2010., First record of Asian clam Corbicula fluminea (Müller, 1774) in the Republic of Moldova: Aquatic Invasions, v. 5 (supplement 1), p. S67-S70, accessed November 19, 2020, at https://doi.org/ 10.3391/ai.2010.5.S1.015. 
Naranjo-García, E., and Castillo-Rodríguez, Z.G., 2017, First inventory of the introduced and invasive mollusks in Mexico: The Nautilus, v. 131, no. 2, p. 107-126, accessed April 25, 2020, at https://www.biodiversitylibrary.org/item/ 276658\#page/5/mode/1up.

Nelson, S.M., and McNabb, C., 1994, New record of Asian clam in Colorado: Journal of Freshwater Ecology, v. 9, no. 1, p. 79, accessed November 19, 2020, at https://doi.org/ $10.1080 / 02705060.1994 .9664429$.

Nguyen, L.T.H., and De Pauw, N., 2002, The invasive Corbicula species (Bivalvia, Corbiculidae) and the sediment quality in Flanders, Belgium: Belgian Journal of Zoology, v. 132, no. 1, p. 41-48, accessed April 14, 2020, at https://biblio.ugent.be/publication/363623/file/457934.

Nico, L.G., Williams, J.D., and Jelks, H.L., 2005, Black carp-Biological synopsis and risk assessment of an introduced species: Bethesda, Md., American Fisheries Society Special Publication 32, $337 \mathrm{p}$.

Normandeau Associates, Inc., 2012, Comparison of benthic macroinvertebrate data collected from the Merrimack River near Merrimack Station during 1972, 1973, and 2011: Bedford, N.H., Normandeau Associates, Inc., technical report, accessed May 18, 2020, at https://www3.epa.gov/ region1/npdes/merrimackstation/pdfs/ar/AR-870.pdf.

Olden, J.D., Poff, N.L., and Bestgen, K.R., 2006, Life-history strategies predict fish invasions and extirpations in the Colorado River basin: Ecological Monographs, v. 76, no. 1, p. $25-40$, accessed November 19, 2020, at https://doi.org/ 10.1890/05-0330.

Page, T.L., Neitzel, D.A., Simmons, M.A., and Hayes, P.F., 1986, Biofouling of power plant service systems by Corbicula, in Britton, J.C., and Prezant, R.S., eds., Proceedings of the Second International Corbicula Symposium, Little Rock, Arkansas, June 21-24, 1983: American Malacological Bulletin Special Edition, no. 2, p. 41-46, accessed November 19, 2020, at https://www.biodiversitylibrary.org/bibliography/ 124975\#/summary.

Pagnucco, K.S., Maynard, G.A., Fera, S.A., Yan, N.D., Nalepa, T.F., and Ricciardi, A., 2015, The future of species invasions in the Great Lakes-St. Lawrence River Basin: Journal of Great Lakes Research, v. 41 (supplement 1), p. 96-107, accessed November 19, 2020, at https://doi.org/ 10.1016/j.jglr.2014.11.004.

Paunović, M., Csányi, B., Knežević, S., Simić, V., Nenadić, D., Jakovčev-Todorović, D., Stojanović, B., and Cakić, P., 2007, Distribution of Asian clams Corbicula fluminea (Müller, 1774) and C. fluminalis (Müller, 1774) in Serbia: Aquatic Invasions, v. 2, no. 2, p. 99-106, accessed November 19, 2020, at https://doi.org/10.3391/ ai.2007.2.2.3.
Peck, S.K., Pratt, W.L., Pollard, J.E., Paulson, L.J., and Baepler, D.H., 1987, Benthic invertebrates and crayfish of Lake Mead: Las Vegas, University of Nevada, 83 p., accessed April 18, 2020, at https://digitalscholarship.unlv.edu/water_pubs/98.

Pereira, J.L., Pinho, S., Ré, A., Costa, P.A., Costa, R., Gonçalves, F., and Castro, B.B., 2016, Biological control of the invasive Asian clam, Corbicula fluminea - Can predators tame the beast?: Hydrobiologia, v. 779, p. 209-226, accessed November 19, 2020, at https://doi.org/10.1007/ s10750-016-2816-5.

Phelps, H.L., 1994, The Asiatic clam (Corbicula fluminea) invasion and system-level ecological change in the Potomac River Estuary near Washington, D.C.: Estuaries, v. 17, p. 614-621, accessed November 19, 2020, at https://doi.org/ $10.2307 / 1352409$.

Pigneur, L., Falisse, E., Roland, K., Everbecq, E., Deliege, J., Smitz, J.S., van Doninck, K., and Descy, J., 2014, Impact of invasive Asian clams, Corbicula spp., on a large river ecosystem: Freshwater Biology, v. 59, p. 573-583, accessed November 19, 2020, at https://doi.org/10.1111/fwb.12286.

Poulton, B.C., Kroboth, P.T., George, A.E., Chapman, D.C., Bailey, J., McMurray, S.E., and Faiman, J.S., 2019, First examination of diet items consumed by wild-caught black carp (Mylopharyngodon piceus) in the U.S.: The American Midland Naturalist, v. 182, p. 89-108, accessed November 19, 2020, at https://doi.org/10.1674/0003-0031182.1.89.

Prezant R.S., and Chalermwat, K., 1984, Floatation of the bivalve Corbicula fluminea as a means of dispersal: Science, v. 225 , no. 4669 , p. 1491-1493, accessed November 19, 2020, at https://doi.org/10.1126/ science.225.4669.1491.

Rey, P., and Ortlepp, J., 2002, Koordinierte biologische Untersuchungen am Hochrhein 2000; Makroinvertebraten. Bundesamt für Umwelt, Wald und Landschaft, Bern: Schriftenreihe Umwelt, v. 345, p. 1-98. [*Not viewed by authors.]

Reyna, P., Nori, J., Ballesteros, M.L., Hued, A.C., and Tatian, M., 2018, Targeting clams - Insights into the invasive potential and current and future distribution of Asian clams: Environmental Conservation, v. 45, no. 4, p. 387-395, accessed November 19, 2020, at https://doi.org/10.1017/ S0376892918000139.

Ricciardi, A., 2007, Are modern biological invasions an unprecedented form of global change?: Conservation Biology, v. 21, no. 2, p. 329-336, accessed December 10, 2020, at https://conbio.onlinelibrary.wiley.com/doi/pdf/ 10.1111/j.1523-1739.2006.00615.x. 
Richardson, T.D., and Selby, J.F., 2020, The nonindigenous Asian clam, Corbicula fluminea, in New Hampshire: Northeastern Naturalist, v. 27, no. 2, p. 272-280, accessed November 19, 2020, at https://doi.org/10.1656/ 045.027.0209.

Rinne, J.N., 1974, The introduced Asiatic clam, Corbicula, in central Arizona reservoirs: The Nautilus, v. 88, no. 2, p. 56-61, accessed April 25, 2020, at https://www.biodiversitylibrary.org/item/33812\#page/72/ mode/lup.

Robinson, J.V., and Wellborn, G.A., 1988, Ecological resistance to the invasion of a freshwater clam, Corbicula fluminea -Fish predation effects: Oecologia, v. 77, no. 4, p. 445-452, accessed April 26, 2020, at https://doi.org/ 10.1007/BF00377258.

Rosaen, A.L., Grover, E.A., and Spencer, C.W., 2012, The costs of aquatic invasive species to Great Lake States: East Lansing, Mich., Anderson Economic Group, LLC, 51 p., accessed April 26, 2020, at https://www.andersoneconomicgroup.com/Portals/0/upload/ AEG\%20Report\%20-\%20AIS\%20Econ\%20ImpactFinal.pdf.

Ruelas-Inzunza, J., Gárate-Viera, Y., and Páez-Osuna, F., 2007, Lead in clams and fish of dietary importance from Coatzacoalcos estuary (Gulf of Mexico), an industrialized tropical region: Bulletin of Environmental Contamination and Toxicology, v. 79, no. 5, p. 508-513, accessed November 19, 2020, at https://doi.org/10.1007/s00128007-9285-5.

Sanderson, G.C., and Anderson, W.L., 1981, Waterfowl studies at Lake Sangchris, 1974-1977, in Larimore, R.W., and Tranquilli, J.A., eds., The Lake Sangchris study-Case history of an Illinois cooling lake: Illinois Natural History Survey Bulletin, v. 32, no. 4, p. 656-690, accessed April 25, 2020, at http://hdl.handle.net/2142/44056.

Schmidlin, S., and Baur, B., 2007, Distribution and substrate preference of the invasive clam Corbicula fluminea in the river Rhine in the region of Basel (Switzerland, Germany, France): Aquatic Sciences, v. 69, p. 153-161, accessed November 19, 2020, at https://doi.org/10.1007/s00027006-0865-y.

Schneider, R.F., 1967, Range of the Asiatic clam in Florida: The Nautilus, v. 81, no. 2, p. 68-69, accessed April 25, 2020, at https://www.biodiversitylibrary.org/item/ 34902\#page/80/mode/1up.

Scott, M., and Comstock, O., 2019, Today in energy—Despite closures, U.S. nuclear electricity generation in 2018 surpassed its previous peak: Washington, D.C., U.S. Energy Information Administration, accessed April 9, 2019, at https://www.eia.gov/todayinenergy/detail.php?id=38792.
Scott-Wasilk, J., Lietzow, J.S., Downing, G.G., and Nash, K.L., 1986, The Asiatic clam in Lake Erie, in Britton, J.C., and Prezant, R.S., eds., Proceedings of the Second International Corbicula Symposium, Little Rock, Arkansas, June 21-24, 1983: American Malacological Bulletin Special Edition, no. 2, p. 185-186, accessed November 19, 2020, at https://www.biodiversitylibrary.org/bibliography/ 124975\#/summary.

Sheehan, R., Caffrey, J.M., Millane, M., McLoone, P., Moran, H., and Lucy, F., 2014, An investigation into the effectiveness of mechanical dredging to remove Corbicula fluminea (Müller, 1774) from test plots in an Irish river system: Management of Biological Invasions, v. 5, no. 4, p. 407-418, accessed November 19, 2020, at https://doi.org/ 10.3391/mbi.2014.5.4.11.

Sickel, J.B., 1973, A new record of Corbicula manilensis (Philippi) in the southern Atlantic slope region of Georgia: The Nautilus, v. 87, no. 1, p. 11-12, accessed June 27, 2020, at https://www.biodiversitylibrary.org/item/34829\#page/19/ mode/1up.

Sickel, J.B., 1986, Corbicula population mortalitiesFactors influencing population control, in Britton, J.C., and Prezant, R.S., eds., Proceedings of the Second International Corbicula Symposium, Little Rock, Arkansas, June 21-24, 1983: American Malacological Bulletin Special Edition, no. 2, p. 89-94, accessed November 19, 2020, at https://www.biodiversitylibrary.org/bibliography/ 124975\#/summary.

Sickel, J.B., and Burbanck, W.D., 1974, Bottom substratum preference of Corbicula manilensis (Pelecypoda) in the Altamaha River, Georgia: Association of Southeastern Biologists Bulletin, v. 21, no. 2, p. 84, accessed November 19, 2020, at https://www.biodiversitylibrary.org/ item/240844\#page/250/mode/1up.

Sickel, J.B., Johnson, D.W., Rice, G.T., Heyn, M.W., and Wellner, P.K., 1981, Asiatic clam and commercial fishery evaluation: National Oceanic and Atmospheric Administration [NOAA], National Marine Fisheries Service, NOAA-NMFS Federal Aid Project No. 2-344-R-1, 83 p.

Simard, M.A., Paquet, A., Jutras, C., Robitaille, Y., Blier, P.U., Courtois, R., and Martel, A.L., 2012, North American range extension of the Asian clam in a St. Lawrence River power station thermal plume: Aquatic Invasions, v. 7, no. 1, p. 81-89, accessed November 19, 2020, at https://doi.org/ 10.3391/ai.2012.7.1.009.

Sinclair, R.M., and Ingram, W.M., 1961, A new record for the Asiatic clam in the United States, the Tennessee River: The Nautilus, v. 74, no. 3, p. 114-118, accessed April 25, 2020, at https://www.biodiversitylibrary.org/item/34887\#page/ 138/mode/1up. 
Sinclair, R.M., and Isom, B.G., 1961, A preliminary report on the introduced Asiatic clam Corbicula in Tennessee: Nashville, Tenn., Tennessee Department of Public Health, Tennessee Stream Pollution Control Board, 31 p., accessed April 25, 2020, at https://www.nrc.gov/docs/ML0428/ ML042800067.pdf.

Sinclair, R.M., and Isom, B.G., 1963, Further studies on the introduced Asiatic clam Corbicula in Tennessee: Nashville, Tenn., Tennessee Department of Public Health, Tennessee Stream Pollution Control Board, 75 p., accessed April 26, 2020, at http:/www.nativefishlab.net/library/textpdf/ 19003.pdf.

Siripattrawan, S., Park, J., and Ó Foighil, D., 2000, Two lineages of the introduced Asian freshwater clam Corbicula occur in North America: Journal of Molluscan Studies, v. 66, no. 3, p. 423-429, accessed April 26, 2020, at https://pdfs.semanticscholar.org/6893/ 172069375f2bb3f31898c37f42f2ff1d06ac.pdf.

Smagula, A.P., Nelson, E., and Snook, H., 2018, Asian clam habitat, population density and size range in select New Hampshire waterbodies: Concord, N.H., New Hampshire Department of Environmental Services R-WD-18-18, 25 p., accessed May 7, 2020, at https://www3.epa.gov/region1/ npdes/merrimackstation/pdfs/ar/AR-1612.pdf.

Smith, B.J., Harris, B.S., Harris, T.J., LaBudde, L.A., and Hayer, C., 2018a, A lakewide survey of Asian clam (Corbicula fluminea) distribution at warmwater discharges in Lake Michigan: Journal of Great Lakes Research, v. 44, no. 4, p. 798-804, accessed November 19, 2020, at https://doi.org/10.1016/j.jglr.2018.05.014.

Smith, B.J., Harris, B.S., Harris, T.J., LaBudde, L.A., and Hayer, C., 2018b, Status and trends of the Asian clam (Corbicula fluminea) in the lower Fox River and Green Bay: Journal of Great Lakes Research, v. 44, no. 5, p. 943-949, accessed November 19, 2020, at https://doi.org/ 10.1016/j.jglr.2018.02.012.

Smith, D.G., 1999, A brief history of the freshwater mussels of (Unionoidea) of the Housatonic River system: Sunderland, Mass., Weston, Inc., 13 p., accessed April 17, 2020, at https://semspub.epa.gov/work/01/213143.pdf.

Smith, L.M., Vangilder, L.D., Hoppe, R.T., Morreale, S.J., and Brisbin, I.L., Jr., 1986, Effect of diving ducks on benthic food resources during winter in South Carolina: Wildfowl, v. 37, p. 136-141, accessed April 26, 2020, at https://wildfowl.wwt.org.uk/index.php/wildfowl/article/ view/734.
Sousa, R., Antunes, C., and Guilhermino, L., 2008, Ecology of the invasive Asian clam Corbicula fluminea (Müller, 1774) in aquatic ecosystems-An overview: Annales de Limnologie, International Journal of Limnology, v. 44, no. 2, p. 85-94, accessed November 19, 2020, at https://doi.org/10.1051/limn:2008017.

Sousa, R., Novais, A., Costa, R., and Strayer, D.L., 2014, Invasive bivalves in fresh waters-Impacts from individuals to ecosystems and possible control strategies: Hydrobiologia, v. 735, p. 233-251, accessed November 19, 2020, at https://doi.org/10.1007/s10750-012-1409-1.

Stein, C.B., 1962, An extension of the known range of the Asiatic clam Corbicula fluminea (Muller) in the Ohio and Mississippi Rivers: Ohio Journal of Science, v. 62, no. 6, p. 326-327, accessed June 8, 2020, at https://kb.osu.edu/ bitstream/handle/1811/4898/1/V62N06_326.pdf.

Stodola, A.P., Douglass, S.A., and Shasteen, D.K., 2014, Historical and current distributions of freshwater mussels in Illinois: Champaign, Ill., Illinois Natural History Survey, Prairie Research Institute, University of Illinois UrbanaChampaign, INHS Technical Report 2014 (37), 82 p., accessed June 6, 2020, at https://hdl.handle.net/2142/55649.

Stotts, V.D., D’Loughy, K., and Stotts, D.B., 1977, Waterfowl habitat: Annapolis, Md., Maryland Department of Natural Resources Wildlife Administration, Report 77-2, 6 p. [*Not viewed by authors.]

Strayer, D.L., 1999, Effects of alien species on freshwater mollusks in North America: Journal of the North American Benthological Society, v. 18, no. 1, p. 74-98, accessed April 28, 2020, at https://doi.org/10.2307/1468010.

Sweeney, P., 2009, First record of Asian clam (Corbicula fluminea) (Muller, 1774) in Ireland: The Irish Naturalists' Journal, v. 30, no. 2, p. 147-148, accessed June 4, 2020, at https://www.jstor.org/stable/pdf/41419056.pdf.

Thomas, N.A., and Mackenthun, W.M., 1964, Asiatic clam infestation at Charleston, West Virginia: The Nautilus, v. 78, no. 1, p. 28-29, accessed November 6, 2020, at https://www.biodiversitylibrary.org/item/34877\#page/42/ mode/1up.

Tiemann, J.S., Haponski, A.E., Douglass, S.A., Lee, T., Cummings, K.S., Davis, M.A., and Ó Foighil, D., 2017 , First record of a putative invasive Corbicula lineage discovered in the Illinois River, Illinois, USA: BioInvasions Records, v. 6, no. 2, p. 159-166, accessed November 19, 2020, at https://doi.org/10.3391/bir.2017.6.2.12. 
Tiemann, J., Lawlis, C., and Douglass, S., 2018, First occurrence of a novel Corbicula (Bivalvia: Corbiculidae) Form D lineage in the Ohio River, USA: The Nautilus, v. 132, no. 1, p. 30-32, accessed November 6, 2020, at https://www.researchgate.net/publication/324209814_First occurrence_of_a_novel_Corbicula_Bivalvia_Corbiculidae Form_D_lineage_in_the_Ohio_River_USA.

Torres-Orozco, R., and Revueltas-Valle, E., 1996, New southernmost record of the Asiatic clam Corbicula fluminea (Bivalvia: Corbiculidae) in Mexico: The Southwestern Naturalist, v. 41, no. 1, p. 60-61, accessed April 25, 2020, at https://www.jstor.org/stable/30054442.

Trebitz, A.S., West, C.W., Hoffman, J.C., Kelly, J.R., Peterson, G.S., and Grigorovich, I.A., 2010, Status of nonindigenous benthic invertebrates in the Duluth-Superior Harbor and the role of sampling methods in their detection: Journal of Great Lakes Research, v. 36, no. 4, p. 747-756, accessed November 19, 2020, at https://doi.org/10.1016/ j.jglr.2010.09.003.

U.S. Army Corps of Engineers, Wisconsin Department of Natural Resources, Minnesota Department of Natural Resources, National Park Service, and U.S. Fish and Wildlife Service, 2010, Results of 2009 monitoring of freshwater mussel communities of the Saint Croix National Scenic Riverway, Minnesota and Wisconsin: St. Paul, Minn., U.S. Army Corps of Engineers, 26 p., accessed April 18, 2020, at https://nr.wi.gov/topic/fishing/ documents/reports/MCT2009MonitorStCroix.pdf.

U.S. Geological Survey [USGS], 2019, Nonindigenous Aquatic Species database: U.S. Geological Survey online database, accessed December 31, 2019, at https://nas.er.usgs.gov.

U.S. Geological Survey [USGS] and U.S. Department of Agriculture, Natural Resources Conservation Service [USDA], 2013, Federal standards and procedures for the National Watershed Boundary Dataset (WBD) (4th ed.): U.S. Geological Survey Techniques and Methods 11-A3, 63 p., accessed November 19, 2020, at https://pubs.usgs.gov/tm/tm11a3/.

Vaughn, C.C., and Spooner, D.E., 2006, Scale-dependent associations between native freshwater mussels and invasive Corbicula: Hydrobiologia, v. 568, no. 1, p. 331-339, accessed April 26, 2020, at https://doi.org/10.1007/s10750006-0210-4.

Veitenheimer-Mendes, I., 1981, Corbicula manilensis (Philippi, 1844) molusco asiatico, na bacia do Jacuí edo Guarba, Rio Grande do Sul, Brasil (Bivalvia, Corbiculidae): Iheringia. Série Zoologia, v. 60, p. 63-74, accessed April 26, 2020, at http://biostor.org/pdfproxy.php?url= https $\% 3 \mathrm{~A} \% 2 \mathrm{~F} \% 2$ Farchive.org $\% 2$ Fdownload $\% 2$ Fbiostor80253\%2Fbiostor-80253.pdf.
Vitousek, P.M., D’Antonio, C.M., Loope, L.L, and Westbrooks, R., 1996, Biological invasions as global environmental change: American Scientist, v. 84, no. 5, p. 468-478, accessed December 10, 2020, at https://www.jstor.org/stable/29775751.

Voelz, N.J., McArthur, J.V., and Rader, R.B., 1998, Upstream mobility of the Asiatic clam Corbicula flumineaIdentifying potential dispersal agents: Journal of Freshwater Ecology, v. 13, no. 1, p. 39-45, accessed November 19, 2020, at https://www.tandfonline.com/doi/abs/10.1080/ 02705060.1998 .9663589 .

Waddell, B., and Wiens, C., 1993, Reconnaissance study of trace elements in water, sediment, and biota of Lake Powell, Interim Report: Salt Lake City, Utah, U.S. Fish and Wildlife Service, 18 p., accessed April 26, 2020, at http://gcdamp.com/images_gcdamp_com/7/79/Waddell_ 1993_Reconnaissance_study_of_trace_elements_water_ sediment_biota_Lake_Powell.pdf.

Weitere, M., Vohmann, A., Schulz, N., Linn, C., Dietrich, D., and Arndt, H., 2009, Linking environmental warming to the fitness of the invasive clam Corbicula fluminea: Global Change Biology, v. 15, p. 2828-2851, accessed November 19, 2020, at https://doi.org/10.1111/j.13652486.2009.01925.x.

White, D.S., Winnell, M.H., and Jude, D.J., 1984, Discovery of the Asiatic clam, Corbicula fluminea in Lake Michigan: Journal of Great Lakes Research, v. 10, no. 3, p. 329-331, accessed November 19, 2020, at https://doi.org/10.1016/ S0380-1330(84)71847-8.

Williams, E.H., Jr., Bunkley-Williams, L., Lilyestrom, C.G., and Ortiz-Corps, E.A.R., 2001, A review of recent introductions of aquatic invertebrates in Puerto Rico and implications for the management of nonindigenous species: Caribbean Journal of Science, v. 37, nos. 3-4, p. 246-251, accessed April 25, 2020, at http://www.biology.uprm.edu/ facultad/publications/Lucy_Bunkley_20010101_5.pdf.

Williams, J.D., Bogan, A.E., Butler, R.S., Cummings, K.S., Garner, J.T., Harris, J.L., Johnson, N.A., and Watters, G.T., 2017, A revised list of the freshwater mussels (Mollusca: Bivalvia: Unionida) of the United States and Canada: Freshwater Mollusk Biology and Conservation, v. 20, no. 2, p. 33-58, accessed November 19, 2020, at https://doi.org/ 10.31931/fmbc.v20i2.2017.33-58.

Williams, J.D., Butler, R.S., Warren, G.L., and Johnson, N.A., 2014, Freshwater mussels of Florida: Tuscaloosa, Ala., University of Alabama Press, 498 p. 
Williams, J.D., Warren, Jr., M.L., Cummings, K.S., Harris, J.L., and Neves, R.J., 1993, Conservation status of freshwater mussels of the United States and Canada: Fisheries, v. 18, no. 9, p. 6-22, accessed November 19, 2020, at https://doi.org/10.1577/15488446(1993)018<0006:CSOFM $\mathrm{O}>2.0 . \mathrm{CO} ; 2$.

Wittmann, M.E., Chandra, S., Reuter, J.E., Caires, A., Schladow, S.G., and Denton, M., 2012a, Harvesting an invasive bivalve in a large natural lake-Species recovery and impacts on native benthic macroinvertebrate community structure in Lake Tahoe, USA: Aquatic Conservation, Marine and Freshwater Ecosystems, v. 22, no. 5, p. 588-597, accessed November 19, 2020, at https://doi.org/ 10.1002/aqc. 2251 .

Wittmann, M.E., Chandra, S., Reuter, J.E., Schladow, S.G., Allen, B.C., and Webb, K.J., 2012b, The control of an invasive bivalve, Corbicula fluminea, using gas impermeable benthic barriers in a large natural lake: Environmental Management, v. 49, no. 6, p. 1163-1173, accessed November 19, 2020, at http://link.springer.com/article/ 10.1007\%2Fs00267-012-9850-5\#page-1.
Yang, R., and Yoshino, T.P., 1990, Immunorecognition in the freshwater bivalve, Corbicula fluminea I. Electrophoretic and immunologic analyses of opsonic plasma components: Developmental and Comparative Immunology, v. 14, no. 4, p. 385-395, accessed November 19, 2020, at https://doi.org/ 10.1016/0145-305X(90)90031-9.

Yeager, M.M., Neves, R.J., and Cherry, D.S., 2000, Competitive interactions between early life stages of Villosa iris (Bivalvia: Unionidae) and adult Asian clams (Corbicula fluminea), in Tankersley, R.A., Warmolts, D.I., Watters, G.T., Armitage, B.J., Johnson, P.D., and Butler, R.S., eds., Part II. Proceedings of the First Symposium of the Freshwater Mollusk Conservation Society: Columbus, Ohio, Ohio Biological Survey, p. 253-259. 
For more information about this publication, contact Director, Wetland and Aquatic Research Center U.S. Geological Survey

7920 NW 71st St.

Gainesville, FL 32653

For additional information, visit https://www.usgs.gov/centers/wetland-and-aquatic-research-centerwarc

Publishing support provided by Lafayette Publishing Service Center 


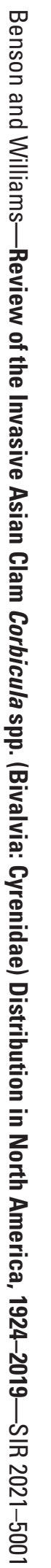

